UNIVERSIDADE DE SÃO PAULO

INSTITUTO DE PSICOLOGIA

SANDRA APARECIDA SERRA ZANETTI

A opção por não se vincular amorosamente de maneira compromissada entre as condições de existência contemporâneas e a herança psíquica geracional 


\section{A opção por não se vincular amorosamente de maneira compromissada entre as condições de existência contemporâneas e a herança psíquica geracional}

Versão Original

Tese apresentada ao Instituto de Psicologia da Universidade de São Paulo para obtenção do título de Doutor em Psicologia Clínica.

Área de Concentração: Psicologia Clínica.

Orientadora: Profa. Titular Isabel Cristina Gomes. 
Zanetti, Sandra Aparecida Serra.

A opção por não se vincular amorosamente de maneira compromissada entre as condições de existências contemporâneas e a herança psíquica geracional / Sandra Aparecida Serra Zanetti; orientadora Isabel Cristina Gomes. -- São Paulo, 2012.

$166 \mathrm{f}$.

Tese (Doutorado - Programa de Pós-Graduação em Psicologia. Área de Concentração: Psicologia Clínica) - Instituto de Psicologia da Universidade de São Paulo.

1. Intersubjetividade 2. Vínculo emocional 3. Relações entre gerações 4. Fatores socioculturais 5. Contemporaneidade I. Título.

B824.18 


\section{FOLHA DE APROVAÇÃO}

Sandra Aparecida Serra Zanetti

A opção por não se vincular amorosamente de maneira compromissada entre as condições de existência contemporâneas e a herança psíquica geracional

Tese apresentada ao Instituto de Psicologia da Universidade de São Paulo para obtenção do título de Doutor em Psicologia Clínica.

Área de Concentração: Psicologia Clínica.

Aprovado em:

\section{Banca Examinadora}

$\operatorname{Prof}(\mathrm{a}) . \operatorname{Dr}(\mathrm{a})$

Instituição: Assinatura:

Prof(a). Dr(a).

Instituição: Assinatura:

Prof(a). Dr(a).

Instituição: Assinatura:

Prof(a). Dr(a).

Instituição: Assinatura:

Prof(a). Dr(a).

Instituição: Assinatura: 


\section{Agradecimentos}

Agradeço, inicialmente, aos meus pais, Walter e Sonia, por terem cuidado para que sempre houvesse a possibilidade de bem estudarmos, possibilitando-me chegar até aqui e ser quem sou. Aos meus irmãos, Ana Paula e Sidney, aos quais guardo um carinho profundo e eterno.

À Isabel Cristina Gomes, minha referência, querida e eterna professora, companheira de jornada. Ensinou-me muito mais do que sempre quis, sendo um exemplo vivo de dedicação e amor à pesquisa, à psicologia, à carreira, à sua família e à vida!

À Fundação de Amparo à Pesquisa do Estado de São Paulo (FAPESP) e à Coordenação de Aperfeiçoamento de Pessoal de Nivel Superior (CAPES), pelo apoio financeiro que permitiu o desenvolvimento pleno desta pesquisa. Em especial à FAPESP, pelo beneficio de trocas acadêmicas em nível nacional e internacional, e à CAPES, pelo estágio no exterior.

Ao psicanalista Al6erto Eiguer por sua disponibilidade em receber-me no estágio de doutorado em Paris, período bastante rico em experiências pessoais e de formação profissional.

Às professoras Maria Lúcia de Souza Campos Paiva e Isabel da Silva Khan Marin, presentes no Exame de Qualificação, cujas contribuições foram de extremo valor para que o trabalho ganhasse em consistência e profundidade.

A todos os participantes desta pesquisa, que gentilmente me concederam informações preciosas sobre suas histórias de vida, fundamentais para a realização desta tese e sem as quais esta perderia em muito em vida e riqueza.

Ao Luis e sua família, pelo carinho de sempre, pelos anos de companheirismo, dedicação e apoio significativos em minha vida.

Aos meus amigos queridos, Juliana, Sinara, Marcela, Kelly, Brunella, Laura, Maria, Cíntia, Carmem, Maíra, Érikga, Maria Angela, Rosilene e Lúcia que de um modo especial estiveram em meus pensamentos e em minha trajetória, tornando-se referências de vida e de caminho a seguir. 
A todos do grupo do "Laboratório de Casale Família: clínica e estudos psicossociais" por todas as nossas discussões de valiosas contribuições para o meu trabalho. Em especial à Maria, Brunella, Laura, Cíntia, Carmem e Rosilene pelas parcerias em trabalhos e congressos.

$\mathcal{A}$ todos que, direta ou indiretamente, contribuíram para a realização deste trabalho, o meu sincero muito obrigada! 
(...) o infinito suceder cósmico e histórico, que nos precede, nos envolve e nos habita, sempre, e em toda parte, do nascer ao morrer, só se torna um evento para o sujeito quando este o situa no seu aqui e o temporaliza no seu agora; enfim, quando o sujeito o concebe sob um certo ponto de vista e o acolhe dentro de uma certa tonalidade afetiva.

Alfredo Bosi 


\section{Resumo}

Zanetti, S. A. S. (2012). A opção por não se vincular amorosamente de maneira compromissada entre as condições de existências contemporâneas e a herança psíquica geracional. Tese de Doutorado, Universidade de São Paulo, São Paulo.

A contemporaneidade contempla condições socioculturais e econômicas de existência que representam um cenário competitivo, com valores instáveis e efêmeros, em que a individualidade toma um lugar central e promove sujeitos mais autônomos e, ao mesmo tempo, mais fragilizados. Diante dessas condições, o que podemos observar, em decorrência, é uma fragilização em torno da construção e manutenção dos vínculos intersubjetivos. Assim, nasceu um interesse em investigar a falta de compromisso com que são formados os vínculos amorosos atualmente, situando-os em meio às condições de existências atuais. No entanto, como partíamos do viés psicanalítico vincular para compreender a formação do sujeito, também supúnhamos o efeito considerável da herança psíquica geracional, na composição do fenômeno. Dessa forma, este estudo teve como objetivo compreender a construção subjetiva de adultos que optam por não se vincular amorosamente de maneira compromissada, em meio às condições contemporâneas de existência e à herança psíquica familiar. Com base na metodologia de pesquisa clínico-qualitativa, foram realizadas entrevistas semidirigidas com seis participantes, de ambos os sexos, com idade entre 25 e 35 anos, que se autodenominavam "solteiros por opção". A análise dos dados referendou-se no aporte teórico psicanalítico intrapsíquico e vincular, por um lado, e nos estudos psicossociais, por outro. Buscou-se construir uma narrativa em que fosse possível representar uma compreensão profunda sobre a opção escolhida, abordando aspectos conscientes e inconscientes, de origem sociocultural, intrapsíquica e herdada inter e/ou transgeracionalmente. A história particular e o funcionamento psíquico de cada um dos indivíduos foram fundamentais para o entendimento do fenômeno estudado. Todos eles demonstraram ter características subjetivas identificadas à atualidade, como o "narcisismo moderno", o "consumismo" ou o "modelo tecnológico" de se relacionar, mas o conteúdo que dava sentido a esses elementos subjetivos era de origem intrapsíquica ou geracional. Outro aspecto constatado foram suas dificuldades em lidar com a frustração. Entendemos que as condições de vida atuais tendem a devolver o sujeito para o "miolo" de si mesmo, o que dificulta o convívio com a alteridade. O mesmo cenário contemporâneo que aborda a pluralidade dos valores e sustenta formas diferenciadas de opções favorece um posicionamento mais coerente com as possibilidades e vontades dos sujeitos, como é o caso de nossos participantes, ao mesmo tempo em que interfere na estabilidade dos vínculos, porque sujeitos mais frágeis estão menos dispostos a lidar com os conflitos próprios de um vínculo. Certa indisponibilidade psíquica para o contato com a alteridade foi verificada em todos os casos, e a opção por não construir um vínculo amoroso compromissado aponta como mais uma possibilidade dentre outras, neste contexto.

Descritores: intersubjetividade; vínculo emocional; relações entre gerações; fatores socioculturais; contemporaneidade. 


\section{A6stract}

Zanetti, S. A. S. (2012). The option for not have a loving link in a committed way between the conditions of contemporary existences and the generational psychic inheritance. Doctoral Thesis, Institute of Psychology, University of São Paulo, São Paulo.

The contemporaneity contemplates sociocultural and economical conditions of existence that represent a competitive scenary, with unstable and ephemeral values, in which individuality takes a central place and promotes more autonomous individuals and at the same time more fragilized. Beyond these conditions, what can be observed, as a result, is a weakening around the construction and maintenance of intersubjective links. Therefore, an interest was born, investigating the lack of commitment that are formed the love links currently being situated among the conditions of present existences. Nevertheless, as we starting from the psychoanalytical link bias to comprehend the formation of the subject, we also assumed the considerable effect of the generational psychic inheritance composition of the phenomenon. This way, this study had as the aim to comprehend the subjective construction of adults that choose for not have a loving link in a committed way among the contemporary conditions of existence and the familiar psychic inheritance. Based on the clinic-qualitative research methodology, six semi directed interviews have been applied to participants of both sexes, aged from 25 and 35 years old, who described themselves as "singles for option". The analysis of the data was based on the intrapsychic and linkage psychoanalytical theory on one side, and, on the other hand, counted on the psychosocial studies. We searched to construct a narrative in which was possible to represent a profound comprehension about the option chosen, approaching conscious and unconscious aspects, from sociocultural origin, intrapsychic and inherited inter and/or transgenerationaly. The particular history and the psychic functioning of each individual were fundamental to the understanding of the phenomenon studied. All of them showed to have subjective characteristics identified with the currently, as "modern narcissism", "consumerism" or the "technological model" of relating, but the content that gave sense to these subjective elements was from intrapsychic or generational origin. Another aspect noticed was the difficulties on dealing with the frustration. We understood that the current life conditions tend to return the individual to the "center" of himself turning, difficult the living with the alterity. The same contemporary scenary the contemplates the plurality of values and sustains different options favoring a positioning more coherent with the possibilities and wills of the individuals, as is the case of ours participants, at the same time interfering on the stability on the links because more fragile individuals are less willing to deal with the conflicts of a link itself. It has been verified in all cases certain psychic unavailability to the contact with alterity, and the option for not constructing a committed loving link is shown as a possibility among others in this context.

Keywords: intersubjectivity; emotional link; intergenerational relations; sociocultural factors; contemporaneity. 


\section{Sumário}

\section{Capítulo I}

Mudanças de um Tempo: solteiros por opção........................................... p. p. 11

1. Apresentação....................................................................................... p. p. 11

2. Revisão Bibliográfica..................................................................... p. p. 14

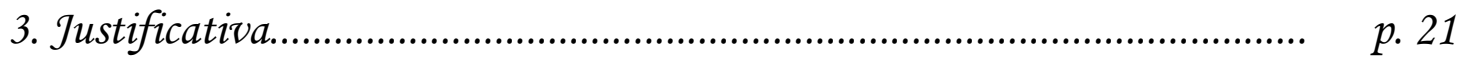

Capítulo II

O Mal-Estar na Sociedade Contemporânea e a Subjetividade ................. p. p. 22

1. O mal-estar na civilização....................................................................... p. p. 22

2. As condições de existências atuais e seus efeitos........................................ p. p. 24

2.1 Efeitos do "Narcisismo", do "Consumismo" e do "Modelo Tecnológico" p. 29

2.2 Relacionamentos Contemporâneos................................................... p. p. 35

3. As raízes do mal-estar no mundo contemporâneo e o psiquismo.................. p. p. 40

\section{Capítulo III}

Da Intersubjetividade à Transmissão Psíquica....................................... p. p. 52

1. Intersubjetividade .......................................................................... p. 52

2. O conceito de Vinculo................................................................... p. 54

2.1 Particularidades do vínculo amoroso.................................................. p. p. 61

3. O trabalho da Transmissão Psíquica...................................................... p. 64

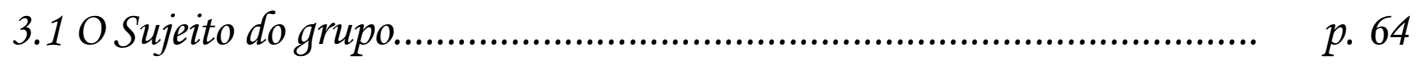

3.2 o processo de Transmissão da Vida Psíquica....................................... p. p. 66

3.3 Mitos Intergeracionais da Família................................................. p. p. 69

\section{Capítulo IV}

Objetivos.....

p. 72

1. Objetivo Geral......................................................................... p.

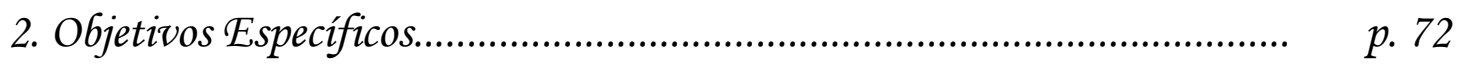

Capítulo $\mathcal{V}$

Método.

1. Materiais e Método 


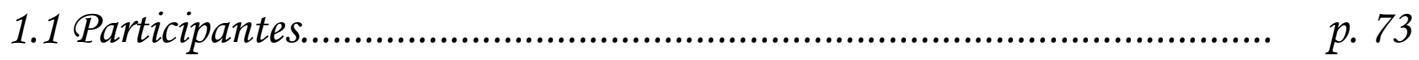

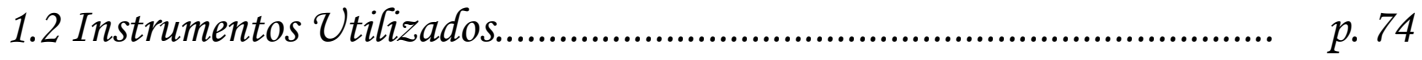

1.3 Procedimentos........................................................................... p. p. 75

2. Fundamentação Teórica do Método........................................................ p. p 76

2.1 A psicanálise como fundamento metodológico..................................... p. p. 77

3. Forma de Análise dos Resultados........................................................... p. p. 77

4. Aspectos Éticos........................................................................... p.

Capitulo VI

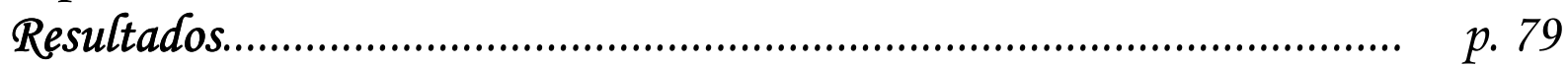

1. Patrícia................................................................................. p.

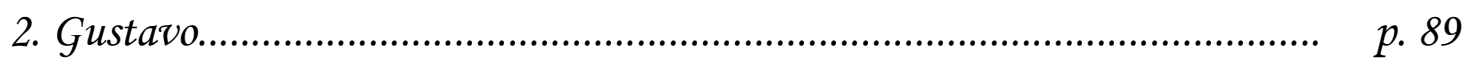

3. Isabella.................................................................................. p. 98

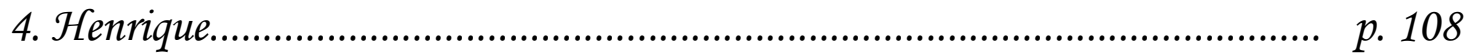

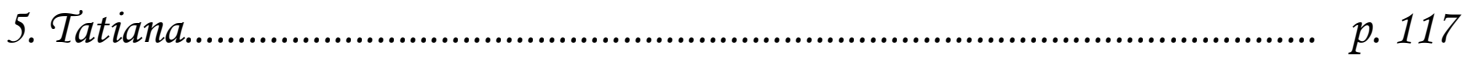

6. João Pedro.................................................................................... p. 127

Capitulo VII

Discussão e Conclusões.................................................................... p. 137

Capítulo VIII

Considerações Finais............................................................................ p. 146

Capítulo IX

Referências..................................................................................... p. 151

Anexo A: Termo de Consentimento......................................................... p. 163

Anexo B: Parecer do Comitê de Ética..................................................... p. 164

Anexo C: Roteiro de Entrevista............................................................. p. 165 
Capítulo I

\section{Mudanças de um tempo: solteiros por opção}

\section{Apresentação}

Procurando compreender o fenômeno da "fragilização dos papéis parentais" (Zanetti, 2008), em minha Dissertação de Mestrado, foi possível verificar o quanto modificações de valores advindos do contexto sociocultural e econômico passaram a influenciar nas formas de organização da família contemporânea, promovendo novos padrões de sociabilidade e de relacionamento entre seus membros. Igualitarismo, democracia, individualismo e liberdade são alguns desses valores que continuam a sustentar mudanças no universo da construção dos vínculos, dentro e fora da família. Atualmente, os vínculos são muito mais regidos pelo grau de satisfação que se pode obter deles do que em função de valores tradicionais. O que outrora era considerado estável ou rígido se configura hoje como "fluido".

São diversos os autores (Bauman, 2001, 2004, 2007, 2009; Giddens, 2007; Lipovetsky, 2004; Sennett, 2008), como se pretende mostrar nesta tese, que depreendem essas mudanças de configurações nos vínculos de um cenário sociocultural e econômico marcado pela efemeridade, pelas incertezas e por toda sorte de descompromissos diante do declínio dos valores tradicionais e das instituições que neles estavam apoiadas. Para Bauman (2001), na "modernidade líquida", como denomina a contemporaneidade, os elos que entrelaçavam as escolhas individuais em projetos e ações coletivas se desmancharam, e o compromisso, a honestidade e todo tipo de valor fundamentado na honra e na solidez dos relacionamentos, hoje, são vistos como "armadilhas" que se procura a todo custo evitar.

A complexidade e os paradoxos nos quais se fundam as bases das condições de existência contemporâneas serão tratados no capítulo que se segue. Por ora, é importante compreender a ponte que sustenta a ligação entre fenômenos. Desde o princípio, assim como Bauman (2004), supusemos que o fenômeno da opção por não ter um vínculo amoroso compromissado na contemporaneidade, ou de ser "solteiro por opção", como é socialmente conhecido, deveria encontrar correspondência com fenômenos socioculturais e econômicos 
atuais, como o "consumismo", o "modelo tecnológico" de se relacionar e o "narcisismo". Essa leitura, na qual pretendemos nos debruçar, nasceu das conjecturas de Bauman (2004), que defende, dentre outras, uma forte ligação entre capitalismo, consumismo, individualismo, efemeridade, instabilidade, vulnerabilidade, redes virtuais etc. com a fragilização atual dos laços humanos, entendendo que a humanidade caminha em direção ao vazio, por cultuar o si mesmo perdido entre mercadorias.

Ou seja, nossa ideia primordial foi a de que o fenômeno ao qual nos dedicamos, embora sempre tenha existido, pode hoje encontrar correlações com mudanças características de nosso tempo. É uma hipótese também sustentada socialmente por meio de reportagens, sites etc.

Destaca o jornal Folha de S. Paulo, de 4 de outubro de 2002: "O aumento do número de pessoas que vivem sozinhas nas grandes cidades, por opção ou contingência, não é uma característica brasileira, e sim uma tendência mundial"1. De acordo com essa reportagem, São Paulo é a cidade brasileira com mais moradores que vivem sozinhos: em 2000, contava com 1 habitante solteiro a cada 30. Em seguida, estão Rio de Janeiro e Porto Alegre. No exterior, em cidades americanas, os indicadores são significativamente maiores: 25,5\% das casas têm apenas um morador. No Reino Unido, os dados informam que, pela primeira vez na história do país, a soma das pessoas que vivem sós, ou como pais solteiros, é maior do que a das que vivem no formato familiar tradicional.

Apesar de esses dados serem significativos, como o que nos interessa é a opção por estar solteiro, a revista IstoÉ, de 28 de outubro de 2009, trazendo na capa a reportagem intitulada "Quero ficar sozinho" (Jordão \& Loes, 2009) confirma que cada vez é maior o número de pessoas que optam por ficar sozinhas e que essa tendência é mundial.

Morar sozinho, segundo a reportagem, tornou-se um estilo de vida graças a um boom de jovens em busca de liberdade, autonomia e melhores condições de vida. Jordão e Loes (2009) observam que, com a permanência da mulher no mercado de trabalho, o contingente feminino conquistou sua independência e, com base em Henriette Morato, psicóloga e professora da USP, declaram que a mulher que morava sozinha, antigamente estigmatizada, carregando a pecha de ser "mal-amada" ou abandonada, hoje é aceita como quem faz essa opção. Os autores ainda sustentam que essa escolha pode estar relacionada com a vida agitada e estressante das grandes metrópoles, o que contribui para o desejo de estar só, de curtir o

\footnotetext{
1"Morar sozinho é tendência mundial". Recuperado em 30 de abril de 2009, de http://www1.folha.uol.com.br/fsp/cotidian/ff0408200202.htm.
} 
silêncio de casa. Nesses casos, o momento de solidão é explicado como um mecanismo de defesa em que o indivíduo busca se proteger de um mundo que propaga uma quantidade ilimitada de informações e na qual se sente diluído. Outro polo importante de sustentação para esse fenômeno é a Internet, que abriu e garantiu o espaço para as relações virtuais (Jordão \& Loes, 2009).

Algumas empresas, percebendo tal fenômeno, têm investido no mercado "single", como é chamado esse nicho, sobretudo nos setores de alimentação, imóveis e serviços. Em São Paulo, por exemplo, a Construtora Gafisa ergueu o edifício Vision Campo Belo. Voltado para quem mora sozinho, possui concierge para aqueles não gostam ou não têm tempo de arrumar o apartamento e serviços pay-per-use, que oferece, dentre outros, o de babá de cachorros. Devido ao sucesso desse empreendimento, a empresa já se prepara para lançar mais dois empreendimentos nesse estilo: Vision Brooklin e Vision Anália Franco, ambos em construção.

A reportagem da UOL "Solteiro, sim, e muito feliz" (Rode, 2010) anuncia o dia 15 de agosto como o "dia dos solteiros" e sugere que se foi o tempo em que ser solteiro era sinônimo de infelicidade. Essa mudança comportamental é alimentada pelo fato de hoje existir maior liberdade sexual para homens e mulheres, ainda que haja resquícios de machismo social (Rode, 2010). De acordo com um depoimento nessa reportagem, a geração dos jovens atuais é em geral individualista, materialista, imediatista, e compromissos com o trabalho, o estudo ou mesmo com as metas pessoais tornaram-se prioritários, em detrimento aos de dedicação ao parceiro. E, nesse sentido, estar solteiro tornou-se um estilo de vida ideal para evitar "desgastes desnecessários" com relacionamentos.

No universo da Internet, pode-se ter acesso a páginas especializadas nesse tema, como http://www.unmarriedamerica.org/mission-ua.html ${ }^{2}$, que disponibiliza diversos tipos de informação e serviço de interesse a pessoas não casadas; $\underline{\text { www.solteirosporopcao.com.br }{ }^{3}}$ e http://encalhadosporopcao.blogs.sapo.pt ${ }^{4}$, em que os solteiros discutem sobre essa opção como um novo estilo de vida; e ainda www.diariodesolteiro.com.br/ $/^{5}$, um blog destinado a contar histórias variadas sobre a vida dos solteiros. Em todos esses sites, o termo solteiro é compreendido como aquele que opta por não ter um vínculo amoroso compromissado.

\footnotetext{
${ }^{2}$ Recuperado em 09 de julho de 2012, de http://www.unmarriedamerica.org/mission-ua.html.

${ }^{3}$ Recuperado em 10 de junho de 2011, de http://www.solteirosporopcao.com.br.

${ }^{4}$ Recuperado em 09 de julho de 2012, de http://encalhadosporopcao.blogs.sapo.pt.

${ }^{5}$ Recuperado em 09 de julho de 2012, de http://www.diariodesolteiro.com.br
} 
Além disso, diversas "comunidades" no site de relacionamentos "Orkut" convidam solteiros por opção a debater sobre o tema. Em alguns depoimentos dessas comunidades, percebeu-se a valorização da liberdade, do não compromisso, a priorização do prazer e da diversão, da qualidade de vida, a importância dada à carreira profissional, à "autonomia emocional", à necessidade de se evitar frustrações naturais de um relacionamento e, ainda, de juntos defenderem-se de certo preconceito social. Diante do questionamento de por que se manter solteiro, certo participante de uma dessas comunidades no "Orkut" respondeu: "Porque não confio em ninguém! Nem na minha mãe eu confio, quanto mais em um outro qualquer! Simplesmente ninguém merece confiança... Tudo isso é um jogo, pura aparência e competição!" No site de relacionamentos "Facebook" também são diversas as páginas especializadas no assunto, mas neste, pode-se ter acesso somente os que fazem parte do grupo.

Assumiu-se, assim, nesta tese, o compromisso de compreender o fenômeno de indivíduos que optam por não ter um vínculo amoroso compromissado na contemporaneidade, tendo como base para esse entendimento o contexto sociocultural e econômico atual, mas também as particularidades psíquicas de cada sujeito, como será tratado posteriormente.

Diante desse panorama, o intuito inicial será o de apresentar pesquisas recentes que discutem o tema em diversos âmbitos e, nos capítulos que se seguem, o de fundamentar teoricamente as bases que proporcionarão maior entendimento acerca do fenômeno.

\section{Revisão Bibliográfica}

O levantamento bibliográfico em artigos internacionais possibilitou o acesso a uma particularidade da literatura que tinha principalmente a intenção de salientar a existência de preconceitos e discriminação, tanto no âmbito cultural quanto acadêmico, em relação aos indivíduos que optam por permanecer solteiros.

DePaulo e Morris (2005) foram precursores desse movimento, por meio de um artigo no qual afirmam que indivíduos solteiros são alvos de "singlism": um termo que, segundo os autores, designa um estereótipo negativo e de discriminação que parte do pressuposto de que ter uma "parceria sexual" tornaria os indivíduos mais felizes e satisfeitos. Esses autores avaliam essa forma de pensamento como um tipo de ideologia falsa, principalmente em uma sociedade em que o número de solteiros vem aumentando. Em outro artigo, DePaulo e Morris 
(2006) argumentam que, comparados aos indivíduos casados ou de união estável, os solteiros têm sido descritos pela literatura como "imaturos", "mal-ajustados" e "egocêntricos". Após o primeiro artigo desses autores, outros se manifestaram em concordância e em prol desse movimento: Byrne e Carr (2005); Williams e Nida (2005); Kaiser e Kashy (2005) são alguns exemplos, demonstrando a relevância e a necessidade de estudar esse tema, diante do aumento significativo do número de pessoas que têm optado por esse estilo de vida, na contemporaneidade.

Contudo, os pesquisadores divergem quanto a considerar essa opção como um estilo de vida que envolve satisfação. Contrariando o que propõem DePaulo e Morris (2005), num trabalho em que se pretendeu estudar a satisfação de indivíduos solteiros diante de suas necessidades de apego e sexual, Schachner, Shaver e Gillath (2008) detectaram que os participantes solteiros, embora exibissem a capacidade de ter "apego seguro" em relação a amigos e parentes, apresentaram maiores taxas de depressão, ansiedade e insatisfação sexual em comparação aos participantes com parceiros amorosos. Além disso, os resultados apontam que os participantes solteiros se mostraram como tendo relacionamentos mais conturbados na infância ou lembrados como contendo maiores problemas, incluindo negligência e indiferença por parte dos pais. Tais dados, segundo os autores, sugerem explicar a escolha por não ter um parceiro amoroso, na idade adulta. Discutem ainda que, a despeito de os estudos de DePaulo e Morris (2005) e de outros sociólogos demonstrem a existência de preconceito quanto a esse estilo de vida, puderam detectar que isso não deve ser a única fonte de insatisfação para esses indivíduos, ou que, pelo menos, não deve ser considerada como a mais importante.

Hostetler (2009), por sua vez, procurou investigar o quanto a escolha por permanecer solteiro, sem um vínculo amoroso compromissado, em homens homossexuais, se tratava realmente de uma opção envolvendo satisfação. Os resultados evidenciaram uma discrepância entre a autopercepção de estar "solteiros por opção", a aceitação e a satisfação pessoal com essa imagem. Os dados indicaram, segundo o autor, que o estilo "solteiro por opção" não se integrava à identidade, mas que podia ser compreendido como uma estratégia narrativa idiossincrática e uma forma de controle secundária, que preserva a integridade do ego.

Davies (2003) elaborou um estudo baseado em histórias de vida de indivíduos heterossexuais adultos e sem filhos que nunca se casaram, para explorar as formas sutis com que as etapas da vida podem influenciar na escolha por permanecer solteiro, aqui em oposição ao casamento. Nesse estudo, mais especificamente, examinou-se como ocorrem as transições na experiência de singlehood, um termo da língua inglesa ligado à condição de estar solteiro. Os dados revelam que há uma mudança na autoatribuição de status que ocorre ao longo do 
tempo e que está associada com um calendário cultural do casamento. E, nesses termos, a experiência de "tornar-se solteiro" aconteceria quando um indivíduo adulto, nessa época, se identificaria mais com a condição de ser solteiro do que com a de ser casado.

De forma geral, ainda que esses artigos internacionais não estejam em acordo uns com os outros, parecem preocupados em compreender esse estilo de vida, no sentido de perceber se realmente se trata de uma opção que envolve satisfação e bem-estar. No entanto, o levantamento bibliográfico em periódicos nacionais, em sua maioria, não ofereceu de imediato teorizações e pesquisas específicas sobre o tema. Ainda assim, foram selecionados alguns estudos que fornecem elementos de reflexão, por discutirem sobre a construção de subjetividades permeadas pelas mudanças do universo sociocultural e suas consequências para a família e para a construção dos vínculos.

No artigo Ninho cheio: a permanência do adulto jovem em sua família de origem, Silveira e Wagner (2006) observam que aspectos atuais relativos à realidade social, política e econômica têm tornado a saída dos filhos da casa paterna mais difícil. A percepção da dificuldade de inserção no mercado de trabalho e da conquista de salários melhores, aliada à vontade de seguir desfrutando do conforto e da segurança que o lar parental oferece são, segundo as autoras, os grandes motivadores da permanência dos filhos adultos na casa dos pais. Segundo dados, $81 \%$ das famílias paulistanas nessa etapa ainda possuem pelo menos um filho adulto jovem em casa. Percebe-se, na análise dos casos coletivos, de 27 a 35 anos, que muitos deles não possuem parceiros amorosos. As autoras compreendem, apoiando-se em Jablonski (2005), que os jovens hoje parecem estar priorizando "a realização individual, mantendo perspectivas de vida ligadas à autonomia, à independência e à satisfação pessoal” (Silveira \& Wagner, 2006, p. 445), o que, nesses casos, os mantém na casa dos pais por mais tempo.

Pensando a respeito de mulheres que optam por ficar solteiras, Antunes (2010) examina o imaginário construído por revistas atuais em torno do perfil das "novas solteiras": elas são universitárias, algumas com cursos de pós-graduação, possuem cargos elevados, moram sozinhas, são de classe média ou alta, não têm filhos, divertem-se muito e não focam suas vidas num relacionamento ou em construir uma família. Em seu levantamento de dados, Antunes (2010) constata o impacto que a escolaridade e a profissionalização exercem sobre suas escolhas, no âmbito da conjugalidade e da maternidade, "implicando novos posicionamentos das mulheres perante a sexualidade e a reprodução" (p. 95). Algumas reportagens, como a da revista Veja - "Com diploma, sem marido" (Sekeff, 2006) -, sugerem que o aumento nos anos de estudo da mulher tende a "estimular a solteirice". Entretanto, para 
a autora, nesses tipos de reportagens a relação causal estabelecida supõe que a potencialidade de um projeto de vida profissional bem-sucedido ou, de maneira mais ampla, qualquer projeto que implique uma utopia emancipatória resulte, necessariamente, na consecução de vida de solteira.

A discussão da dissertação de Antunes (2010) visa a mostrar que essas mulheres estão tão comprometidas com um projeto emancipatório que este pode se constituir como outra forma de aprisionamento, pois elas opõem rigidamente suas histórias àquela da dominação masculina em que o casamento é visto ainda como opressor. Em busca de uma articulação possível entre os ideais antigos e novos, a autora assume a postura de que o casamento também pode sofrer reformulações, de forma que a escolha para se focar na carreira não seja excludente de outros projetos de vida, como a de conviver com um companheiro e/ou ter filhos. O que essa autora procurar ressaltar é uma ideia disseminada na sociedade de uma incompatibilidade entre projetos individuais ligados à carreira e projetos de vida em comum. Projetos de vida voltados para a realização pessoal têm sido amplamente valorizados em nossa sociedade atual e pensamos, assim como Antunes (2010), que esse tipo de valorização individualista pode estar ligado ao fenômeno com o qual nos ocupamos nesta tese.

Pesquisando relações afetivas na contemporaneidade, Gomes e Silva Júnior (2007) refletem sobre as implicações da decomposição dos "laços públicos" e o consequente aniquilamento do exercício político, em decorrência de um cenário "líquido" e de processos de individualização. Embora não tenha se focado em relacionamentos amorosos, esse estudo é interessante pelas reflexões que suscita a respeito de como os efeitos do mundo econômico interferem na formação dos laços. Foram entrevistados trabalhadores de cooperativas populares, com o objetivo de conhecer suas histórias de amizade, com base na ideia de que o cooperativismo representa um polo de resistência à economia capitalista. Realmente, dentre os resultados, foi detectado que esses laços são importantes por comportar acolhimento e comprometimento com o outro, por meio do qual se vive o vigor da solidariedade. No entanto, ao mesmo tempo, os autores constataram que as narrativas revelaram igualmente a "contemporânea fragilidade dos laços", o isolamento social e o individualismo, o que significa que "o mercado capitalista, ao transformar vínculos humanos e pessoas em mercadorias, tem promovido o esfacelamento da solidariedade humana e das habilidades de sociabilidade" (p. 57), nos diversos setores da sociedade. Apoiados em Bauman (2004), consideram que os "vínculos humanos transformados em objetos de consumo passam a ser valorizados pelos novos atributos de conveniência de uso e descartabilidade, próprios do ato 
de consumir - processo que privilegia os 'relacionamentos rápidos', de pouca durabilidade, que não implicam engajamento e esforço" (p. 63).

Estudando, mais especificamente, relacionamentos amorosos na contemporaneidade, outros autores (Baroncelli, 2011; Rios, 2008; Justo, 2005) concordam que o impacto da conjuntura atual nas novas configurações faz priorizar a ausência de compromissos e de exclusividade. Esses autores, portanto, reforçam a nossa tese de que o fenômeno estudado tem relações com valores e fenômenos contemporâneos socioculturais e econômicos.

Rios (2008) salienta o quanto uma relação amorosa duradoura depende, depois de passado o estado de apaixonamento, da disponibilidade psíquica de reconhecer o outro, sua alteridade, e que esse processo pode estar se tornando dificultoso em uma "Cultura Narcísica”. A autora observa que a experiência do encontro amoroso se associa a uma subjetividade construída nas bases "de um eu que passou pela fase do narcisismo primário, dele saiu competente para a experiência da alteridade, e que se mantém e se reforça durante a vida em uma cultura que lhe ofereça modelos de sustentação da intersubjetividade" (p. 422). Contudo, a cultura contemporânea, como ressalta a autora, "reproduz conceitos e práticas que não sustentam a alteridade, e constantemente devolvem o sujeito para o miolo de si mesmo quando este procura referências fora de si, na experiência coletiva” (p. 423). Assim, conforme a autora, na atualidade, é a possibilidade do encontro intersubjetivo que está em jogo. As pessoas se agrupam para trabalhar, para estudar, para ganhar dinheiro, mas isso não necessariamente se caracteriza como um encontro intersubjetivo, porque em nossa sociedade, como efeito das condições de existência, cada um está mais interessado em falar de si do que ouvir o outro, enfatiza Rios (2008). "Falta disposição interna para escutar, refletir, construir junto um pensamento compartilhado, produto de um encontro" (p. 423). Ela conclui que optar por ficar só é uma saída, quando se percebe que o amor de "boa qualidade", o "amor de verdade" exige tempo e grande disponibilidade:

Amar dá trabalho. E o ganho pode parecer pouco - especialmente quando se vive em um mundo como o nosso, que nos cobra a busca por um fictício estado prazeroso ininterrupto. $\mathrm{O}$ ganho, que não está previsto nessa conta que soma êxtases, é aquele que não se percebe de imediato: as transformações do eu na experiência da intersubjetividade. (Rios, 2008, p. 424).

Para Justo (2005), a condição de aceleração do tempo, de alargamento de espaço e movimentação humana sem precedentes é impeditiva de vinculações psicossociais estáveis e prolongadas, em todos os planos da vida. A era da "instantaneidade", em que tudo funciona 24 horas por dia, propõe uma vida em que não se torna necessário postergar nenhum desejo ou necessidade, afastando o "fantasma da frustração", assinala. "Dentro do referencial 
psicanalítico, entenderíamos essa condição como de soberania do processo primário sobre o secundário, tal como funciona o bebê ao exigir o pronto atendimento e a satisfação de suas necessidades e desejos" (Justo, 2005, pp. 67-68). Entende ainda, baseando-se em Bauman (2004), que o consumismo favorece uma disponibilização psicológica para o descarte, incluindo o de pessoas, moldando uma nova forma de relacionamento pautado pela efemeridade e o imediatismo. Em última instância, "trata-se, portanto, de um mundo que não favorece a aproximação entre as pessoas, a criação de vínculos duradouros, a associatividade e a grupalização" (Justo, 2005, p. 70).

Procurando compreender o ciúme presente nas relações amorosas contemporâneas, Baroncelli (2011) salienta que, em função da experiência amorosa se ver marcada atualmente por intensa transitoriedade, flexibilidade e abertura, o ciúme extremo pode se revelar como um resultado possível diante de um grande sofrimento que toda essa instabilidade provoca. As ambiguidades da vida contemporânea, observa a autora, enraizadas num contexto de incertezas, potencializam a abertura de um espaço propício aos comportamentos de extremismos, como o consumo de drogas, ligações com bandos e seitas, ou como é o caso do ciúme de caráter mais extremo, que "podem parecer a melhor defesa, ou, pelo menos, a mais viável delas." (p. 169). Deduz, portanto, que o ciúme representa hoje uma das tentativas de controle da vida, "dolorosamente buscado para o gerenciamento da nova condição da experiência amorosa em nossos dias" (p. 169).

Passos (2007), refletindo sobre a Constituição dos laços na família em tempos de individualismo, observa que a fragilidade com que são formados os laços, a falta de compromisso, as dispersões nas relações humanas e as relações de caráter inconsistentes da sociedade têm influenciado na dinâmica da família contemporânea. Esses fatores repercutem no contexto intersubjetivo do grupo familiar, interferindo na configuração dos laços afetivos no espaço da família - origem dos demais laços sociais - e, consequentemente, no processo de subjetivação. No entanto, para a autora, a constituição do sujeito, segundo a psicanálise, implicaria ainda a "assunção de uma dívida face ao outro, sem o qual não teríamos condições de existir" (Birman, 1977 citado por Passos, 2007, p. 120). Essa dívida "se impõe muito antes do que podemos supor: vem dos nossos ancestrais, atravessa gerações e instaura a transmissibilidade psíquica como primeiro eixo na relação intersubjetiva eu-outro, que tem a família como contexto e suporte" (Passos, 2007, p. 120). Portanto, a autora traz para esse debate outro ponto que deve ser pensado com cuidado, quando se trata de fenômenos que interferem na constituição subjetiva: aquilo que se recebeu como herança psíquica dos antecedentes familiares. 
No que se refere à relação entre a conjugalidade dos pais e o projeto de casamento dos filhos, Féres-Carneiro (2005) verificou que o lugar que o casamento ocupa, no projeto de vida dos indivíduos, parece estar associado com o modo como se apropriam de sua herança familiar e com o discernimento acerca dos aspectos da conjugalidade dos pais que influenciam em suas escolhas. Constatou, por exemplo, que na maioria dos casos em que os jovens apresentavam um discurso em que se percebia uma recusa na percepção da influência da conjugalidade dos pais em seus projetos de vida, tais pais haviam sido avaliados como tendo uma conjugalidade muito insatisfatória. A autora considera que esse resultado evidencia o quanto o "não enfrentamento pelos pais de seus conflitos conjugais e a manutenção de uma relação conjugal insatisfatória interferem no processo de identificação e de diferenciação dos filhos e, consequentemente, na possibilidade de elaborar projetos de vida mais autônomos" (p. 96). Acrescenta a importância de se contextualizar o lugar do casamento dos pais, no projeto de vida dos jovens, sem deixar de levar em conta a articulação dessa herança com a constituição da subjetividade contemporânea.

Diante da mesma problemática, Magalhães e Féres-Carneiro (2004) assinalam a necessidade de considerar o contexto sociocultural e econômico atual, marcado por um acelerado processo de mudanças, para compreender o processo de "transmissão psíquica" na contemporaneidade, diante de ligações afetivas que tendem a ser pouco duradouras e os investimentos de grande risco. Decorrentes desse contexto, as autoras enfatizam a existência de processos de "dessimbolização", de falta de referências estáveis, de ausência de figuras de lei, de desvinculação, de rupturas e de descontrole, através dos quais os laços intersubjetivos se afrouxam. Apoiadas em Kaës (1993), um dos autores mais destacados nos estudos sobre a transmissão psíquico-geracional, percebem que existe a necessidade

da precedência por um outro e por mais de um outro no processo de subjetivação e, com base na obra freudiana, evidencia a importância da intersubjetividade. Coloca-se a centralidade do espaço intersubjetivo e, mais especificamente, do espaço e do tempo geracional. O sujeito não é auto-engendrado, e o trabalho psíquico de constituição da subjetividade implica a metabolização da herança no confronto com o outro que transmite. (Magalhães \& FéresCarneiro, 2004, p. 244).

Com base nessa revisão da literatura, observou-se que esta desperta a pensar numa investigação a qual busque compreender a constituição subjetiva de adultos que optam por não se vincular amorosamente de maneira compromissada, diante das condições de existência socioculturais e econômicas contemporâneas, mas também, com base nesses últimos 
trabalhos, da relação que esses sujeitos estabelecem com sua "precedência" e sua “descendência”, ou seja, com o legado geracional ${ }^{6}$ recebido pela família.

Para tanto, nos próximos capítulos introdutórios, procuraremos apresentar o contexto contemporâneo sociocultural e econômico, fundamentar a maneira como esse contexto pode influenciar na estruturação subjetiva e, por fim, aprofundar conceitos sobre a intersubjetividade, o vínculo e o processo de transmissão da vida psíquica.

\section{Justificativa}

É necessário acrescentar que se trata de um fenômeno atual e pouco estudado, que tem despertado o interesse de pesquisadores nacionais e internacionais e, supomos, guarda uma estreita relação com as condições de existência contemporâneas, o que garante importância à pesquisa.

Além disso, dentre as justificativas, aplica-se a de que esta tese pretende gerar conhecimento para a área clínica, pois é fato a presença marcante de pacientes que se queixam de um mal-estar típico da contemporaneidade, ligado às dificuldades de estruturar vínculos intersubjetivos duradouros.

E, finalmente, é importante ainda ressaltar que este estudo se insere no âmbito da pesquisa qualitativa, circunstância a qual igualmente impõe limites à investigação, já que, dessa forma, não priorizou quantificações, controle de variáveis ou tratamentos estatísticos para uma possível avaliação da extensão ou dimensão que o fenômeno pudesse ocupar, na sociedade. Entretanto, por meio de seu caráter qualitativo, foi possível proporcionar um conhecimento profundo do fenômeno estudado e gerar um conhecimento específico e significativo.

\footnotetext{
${ }^{6}$ Esses conceitos serão mais bem desenvolvidos no Capítulo III: Da Intersubjetividade à Transmissão Psíquica.
} 
Capítulo II

O MaL-Estar na Sociedade Contemporânea e a Subjetividade

\section{O mal-estar na civilização}

Foi no verão de 1929 que Freud resolveu iniciar outro livro sobre um assunto sociológico e, mais tarde, sugeriu para seu título O Desconforto do Homem na Civilização. Neste, Freud (1930/2006) procurou explorar o antagonismo, para ele irremediável, entre as exigências do instinto e as restrições da vida em sociedade. Contudo, O Mal-Estar na Civilização, como foi lançado, é uma obra que ultrapassa em muito a sociologia, porque nela o autor entende o modo como sujeito e sociedade se constroem mutuamente, incluindo aí, mas também como efeito desse encontro, o funcionamento do psiquismo. Este capítulo se propõe refletir sobre essas articulações, na contemporaneidade.

Freud (1930/2006) parte do princípio de que o propósito da vida está em alcançar a felicidade, o programa do princípio do prazer, no entendimento de sua teoria. O princípio do prazer domina o funcionamento do aparelho psíquico desde o início da vida, ainda que não haja possibilidade alguma, afirma, de que ele possa ser executado: "todas as normas do universo lhe são contrárias" (p. 84). Já o sofrimento, embora intensamente indesejado, é muito mais fácil de ser experimentado; com efeito, aquele que talvez seja o mais penoso, aponta Freud (1930/2006), provém de nossos relacionamentos com os outros homens. Interessante para nossa tese encontrarmos esse tipo de apontamento em Freud (1930/2006), porque ele ainda continua: contra tal tipo de sofrimento, a defesa mais imediata é o isolamento voluntário, já que "nunca nos achamos tão indefesos contra o sofrimento como quando amamos, nunca tão desamparadamente infeliz como quando perdemos o nosso objeto amado ou o seu amor" (p. 90).

E, apesar das desventuras que envolvem o homem e o impedem de ser feliz, Freud (1930/2006), nessa obra, pretende concentrar-se na civilização como sendo, em grande parte, a responsável por nossas desgraças, pois sustenta que seríamos muito mais felizes se 
pudéssemos retornar a condições primitivas. A patologia de caráter neurótico, por exemplo, nada mais seria do que um quadro representativo de um sofrimento, quando não se pode mais tolerar a frustração imposta pela sociedade a serviço de seus ideais culturais.

Foi buscando organizar a natureza para dela se beneficiar, se proteger e melhor sobreviver que o homem precisou organizar também e, principalmente, a vida em comunidade, por meio da criação de regras para os relacionamentos. Do contrário, "os relacionamentos ficariam sujeitos à vontade arbitrária do indivíduo, o que vale dizer que o homem fisicamente mais forte decidiria a respeito deles no sentido de seus próprios interesses e impulsos instintivos" (Freud, 1930/2006, p. 101). O sentido de uma comunidade está na definição de direitos em oposição ao poder de um determinado indivíduo, e a substituição do poder do indivíduo pelo da comunidade constitui, para o autor, o passo definitivo para a civilização. Por conseguinte, trata-se, em última instância, da restrição das possibilidades de satisfação do indivíduo em prol da justiça, da garantia de que uma lei, uma vez criada, "não será violada em favor de um indivíduo" (p. 102).

No processo do desenvolvimento da civilização, Freud (1930/2005) aponta para o caráter de modificação que ela é capaz de impor às "habituais disposições instintivas dos seres humanos" (p. 103), enquanto consequência deste encontro. Alguns instintos são induzidos a deslocar as condições de sua satisfação, a conduzi-las a outros caminhos. "Na maioria dos casos, esse processo coincide com o da sublimação (dos fins instintivos)" (p. 103), processo psíquico que exige a capacidade de transformação de um impulso libidinal em outra construção: uma criação socialmente aceita e útil. A sublimação do instinto, afirma Freud (1930/2006), constitui um aspecto evidente do desenvolvimento cultural, e é quem torna possível as atividades psíquicas superiores científicas, artísticas etc., tão necessárias à vida civilizada.

Portanto, diante da necessidade do homem de desenvolver recursos para lidar com a natureza, acabou criando a civilização e com a ela também a cultura. Esta última é necessária para que o homem realmente consiga viver em sociedade, mas tem o efeito de causar um malestar na subjetividade relativo à solução de compromisso do homem com a civilização. Foi por meio desse trabalho que Freud (1930/2006) concluiu que as neuroses obsessivas e as histerias podiam ser vistas como efeito de uma sociedade estruturada em torno de uma família tradicional, hierarquicamente organizada, perpassada por uma cultura repressora da sexualidade. Do encontro de um indivíduo com os ideais, com as normas, as regras, a cultura como um todo, nasce uma subjetividade cuja parte do seu mal-estar se ancora no irremediável esforço necessário de abrir mão de parte da satisfação para se viver em comunidade. 
Todavia, como salienta Birman (2011), é preciso considerar as condições atuais do mal-estar na civilização. Mais de 80 anos se passaram e restam para os dias atuais condições de existências bastante diversas daquelas que Freud (1930/2006) observou. Hoje em dia, são outros os sintomas e soluções de compromisso constituintes da subjetividade (sintomas psicossomáticos, depressões, ansiedades, desordens narcísicas, transtornos bipolares, compulsivos, alimentares etc.), fazendo-nos crer que da relação do homem com a civilização que ele mesmo criou, ao longo dos tempos, foi nascendo uma nova cultura, novas formas de relacionamento e novas formas de organização psíquica. Trata-se dos determinantes sociais, econômicos e culturais, da construção de novas crenças e valores, influenciando a constituição subjetiva de nossos contemporâneos.

Nossa intenção, num primeiro momento, será a delinear o contexto sociocultural e econômico contemporâneo pela vertente de filósofos e sociólogos; em seguida, de compreender os efeitos desse contexto para a constituição subjetiva, por meio de três fenômenos contemporâneos ("consumismo", "narcisismo" e "modelo tecnológico") e, num terceiro momento, por intermédio da obra de René Kaës, entender como essa nova cultura e nossa organização social podem influenciar na organização do psiquismo e de uma nova modalidade de mal-estar.

\section{As condiçôes de existências atuais e seus efeitos}

São muitos os sociólogos, historiadores e filósofos que defendem o termo "pósmodernidade" como o mais apropriado para nomear a contemporaneidade, no Ocidente ${ }^{7}$, período que se inicia por volta da década de 30 do século XX até os dias de hoje. Conforme esses autores, as características que a definem são demasiadamente diferenciadas para que se continue a designá-la como modernidade. Lyotard (2008), Vattimo (2003) e Baudrillard (2007) são alguns desses estudiosos, para os quais, de forma geral, os alicerces que sustentavam os projetos da modernidade ruíram e restou para os dias atuais o oposto do pretendido.

A modernidade pode ser pensada como uma época cuja pretensão era a de alcançar um progresso ilimitado, apostando na organização sistemática para conquistar a "emancipação da humanidade", isto é, o fim das desigualdades sociais e o livre desenvolvimento das potencialidades humanas, além do desenvolvimento científico e tecnológico que asseguraria

\footnotetext{
${ }^{7}$ Importante ressaltar que todas as conceitualizações desta tese têm por base o mundo ocidental.
} 
um futuro melhor para todos (Lyotard, 2008). No entanto, diante da percepção do fracasso do projeto modernista, a "pós-modernidade" designa justamente o período que sustenta uma ruptura com essa linearidade temporal marcada pela esperança, culminando na perda de fé na ciência e num desencantamento em relação ao mundo (Baudrillard, 2007; Lyotard, 2008; Vattimo, 2003). “A fé no progresso foi substituída por uma confiança instável, oscilante, variável em função dos acontecimentos" (Lipovetsky, 2004, p. 70).

Autores como Bauman (2001) e Giddens (1991), por sua vez, desenvolveram outro pensamento visando a representar a contemporaneidade e defendem a permanência do termo modernidade, ainda que em sua forma "líquida" ou "derivada de si mesma", respectivamente. Cabe salientar, contudo, que não pretendemos nos alongar nessa temática, entrar em discussões profundas quanto a como denominar a contemporaneidade, porque este estudo tem outros fins. O principal objetivo é extrair dos autores, independentemente do seu posicionamento terminológico, o modo como compreendem as condições socioculturais e econômicas atuais, para delas nos beneficiarmos no entendimento do fenômeno estudado.

Portanto, de maneira breve, segundo Bauman (2001), duas características fazem da atual situação, que ele denomina de "modernidade líquida", nova e diferente. Em primeiro lugar, concordando com os autores pós-modernos, percebe o colapso gradual e o declínio da "ilusão moderna" de que há um estado de perfeição a ser atingido; e, em segundo, constata a desregulamentação e a privatização das tarefas e dos deveres modernizantes. Entretanto, apesar de esses aspectos providenciarem características diferenciadas, tanto para Bauman (2001), como para Giddens (1991), não são suficientes para que juntos designem o início de uma nova época completamente diferente do que propunha a modernidade. Entendem que são os traços, os efeitos e as consequências da modernidade que ainda estão em jogo.

Com o desenvolvimento da modernidade, alguns dos seus principais resultados foram a fragmentação do que costumava ser visto como propriedade coletiva da humanidade e a individualização da sociedade, deixando a administração dos indivíduos a seus próprios recursos, de acordo com Bauman (2001). A ênfase, para esse autor, transladou-se para a autoafirmação do indivíduo, e essa alteração tem também como resultado o acúmulo das responsabilidades, principalmente dos fracassos, sobre eles.

Analisando o cenário social, Bauman (2001) observa que basicamente os padrões de referência outrora rígidos se tornaram maleáveis, mas considera tais resultados inquietantes. A principal ideia em que se baseia para denominar a modernidade de "líquida" é a de que, no projeto em busca da perfeição e da emancipação da humanidade, o que ocorreu foi um processo de tornar o mundo, os padrões de referência, as parcerias e todo tipo de 
relacionamento sustentado no compromisso, na honra e na solidariedade, "líquidos". Ou seja, com o advento da flexibilidade em torno das normas e dos padrões de referência, o autor enxerga o nascimento da instabilidade e da vulnerabilidade dos indivíduos, já que verifica uma desintegração ao redor da construção dos valores "sólidos", estruturantes do ponto de vista da constituição identitária e subjetiva. Consolidando esse movimento, está um sistema econômico que tratou de "diluir" valores "sólidos", quando foram percebidos como empecilhos para o bom desenvolvimento das instituições que objetivavam sobretudo o lucro, pois restringiam movimentações financeiras. Assim, não se trata do desenvolvimento da democracia e da liberdade de expressão somente, mas do sistema capitalista moldando condições sociais para se promover, segundo o autor.

Consequentemente, mas de forma não esperada, os "sólidos" que também acabaram por "derreter" foram os "elos que entrelaçavam as escolhas individuais em projetos e ações coletivas - os padrões de comunicação e coordenação entre as políticas de vida conduzidas individualmente, de um lado, e as ações políticas de coletividades humanas, de outro" (Bauman, 2001, p. 12). Com essas transformações, o autor observa que, no mundo atual, a lealdade e todo o tipo de compromisso baseados em valores "sólidos", como a honra e a honestidade, passaram a ser motivos de vergonha e não de orgulho.

Além dessas modificações essenciais de valores, Giddens (1991) assinala ainda como importante característica de nossa época o ritmo das mudanças sem precedentes no que toca à tecnologia e outras esferas. E, assim, não são somente as mudanças, mas a velocidade com que acontecem deixam marcas sociais, estas muito mais fáceis de ser apagadas, porque desaparecem com a mesma velocidade com que surgem. “Líquido-moderna”,, comenta Bauman (2009), "é uma sociedade em que as condições sob as quais agem seus membros mudam num tempo mais curto do que aquele necessário para a consolidação, em hábitos e rotinas, das formas de agir" (Bauman, 2009, p. 7).

No entanto, para Lipovetsky (2004, 2005), que pretende uma leitura mais complexa e ampla do fenômeno global, a modernidade significa não só o surgimento dos valores instáveis, hedonistas e permissivos. Para além do enfraquecimento da sociedade e dos costumes, aponta o nascimento da autonomia e da liberdade, de uma sociedade voltada para o indivíduo, que dá espaço para o pessoal e o psicológico, com a emergência de um modo de socialização e individualização inéditos a partir dos séculos XVII e XVIII, no Ocidente.

À medida que as sociedades democráticas avançadas se desenvolveram, encontraram sua inteligibilidade à luz da lógica da personalização. Esse processo teve seu início desde 1950 e fez diminuir o controle disciplinar sobre os indivíduos, remodelando continuamente e 
em profundidade o conjunto dos setores da vida social (Lipovetsky, 2005). É dessa maneira, para esse autor, que a "sensibilidade política da década de 1960 dá lugar a uma 'sensibilidade terapêutica"” (Lipovetsky, 2005, p. 35).

Entretanto, conforme Lipovetsky (2004), após os anos 80 diversos sinais indicam para o surgimento de mais uma época, não mais pós-moderna, mas hipermoderna. "Trata-se não mais de sair do mundo da tradição para acender à racionalidade moderna, e sim de modernizar a própria modernidade, racionalizar a racionalização" (p. 56). A hipermodernidade pode ser compreendida como uma sociedade liberal, "caracterizada pelo movimento, pela fluidez, pela flexibilidade; indiferente como nunca antes se foi aos grandes princípios estruturantes da modernidade, que precisam adaptar-se ao ritmo hipermoderno para não desaparecer" (Charles, 2004, p. 26).

Lipovetsky (2004) nota, juntamente com o advento do individualismo, fenômenos de reconstituição e de "reciclagem" na sutileza dos detalhes. Segundo sua perspectiva, mesmo que o consumismo, a efemeridade e os mecanismos de fragmentação se observem por toda parte, é possível encontrar construções mais legítimas, a valorização do amor, da sociabilidade e o voluntariado. O autor apresenta uma leitura menos pessimista e mais sensata, a nosso ver, já que também não se enclausura uma construção idílica: sua leitura aborda o paradoxo contemporâneo. Ele concorda que o indivíduo atual, embora mais autônomo, é mais frágil à medida que as obrigações e as exigências que o cercam são mais vastas e mais pesadas. Comentando-o, Tavoillot (2004) observa, a partir de sua obra, que a "liberdade, o conforto, a qualidade e a expectativa de vida não eliminam o trágico da existência; pelo contrário, tornam mais cruel a contradição" (p. 9).

Os autores, de modo geral, compreendem que essas vulnerabilidade e instabilidade a que nossos contemporâneos estão expostos, atualmente, advêm da forma como a conjuntura atual se apresenta. A liberdade em torno das normas e dos padrões de sociabilidade ainda se soma às condições de trabalhos instáveis, pouco confiáveis; aos efeitos da globalização, que abriu a possibilidade de um mundo novo, sem precedentes (Giddens, 2007); e aos efeitos do desenvolvimento tecnológico e do advento da Internet. São fenômenos que, em conjunto, podem levar ao esfacelamento das referências identitárias e ao desconforto da insegurança (Bauman, 2001).

Sennett (2008) preocupa-se, pois entende que, devido ao fato de os empregos terem se tornados inseguros, os indivíduos nunca sabem bem o que esperam deles; e, em face da existência de uma constante "reengenharia" das corporações, não se encontra mais nas relações de trabalho uma das bases para a construção de uma identidade sólida. O "princípio 
da flexibilidade" proposto pelo mundo do trabalho, para esse autor, preconiza que os indivíduos aprendam a se tornarem capazes de se desvincular do passado e da necessidade de confiança para aceitar a ideia de fragmentação. Esse tipo de mentalidade, embora bastante atraente aos "donos do capital", é pouco legível, "sem forma" e produz uma sensação de um mundo incompreensível, segundo o autor. Como consequência, indivíduos tornam-se pouco solidários e indiferentes entre si, em função de uma crise de orientação ante um mundo fragmentado e "não-interpretável".

Bauman (2009) concorda e assinala que o lema da "flexibilidade" contaminou todo o conjunto social, o que, a seu ver, significa que todas as formas, não só no mundo do trabalho, “devem ser maleáveis, todas as condições, temporárias, todos os formatos, passíveis de remodelagem" (p. 123). Lipovetsky (2004), por sua vez, pensa que se trata da lógica da brevidade, com a compressão do espaço-tempo, por causa de um sistema globalizado neoliberal e da revolução da informática.

Todos os nossos principais problemas agora são de nível global e, por isso, não podem ser administrados localmente, o que gera a sensação de perda de controle e de impotência. Nem a democracia, nem a segurança e nem a liberdade podem ser garantidas em nossa época. Indefesas, as pessoas aferram-se em si mesmas e, assim, mais indefesas tendem a ficar (Bauman, 2007).

Giddens (2007) enfatiza que, em épocas passadas, o conhecimento proporcionado pela ciência tinha o poder de trazer segurança, ainda que tivesse o intuito de superar a tradição. Atualmente, todavia, quanto mais a ciência e a tecnologia entram em nossas vidas - e o fazem num nível global -, menos essa perspectiva se sustenta, porque os achados da ciência são cada vez mais controversos. Viver numa era global, afirma o autor, significa enfrentar uma diversidade de situações de risco, mas também representa uma economia dinâmica de uma sociedade inovadora, afinal, "uma raiz do termo 'risk' no original português significa 'ousar'” (Giddens, 2007, p. 45).

Em uma sociedade incapaz de oferecer o "conforto existencial", a saída foi decidir-se pela segurança, ressalta Bauman (2009). Esse autor assinala que, à medida que os medos se tornaram autoperpetuadores e autorreforçadores, muito dinheiro passou a ser ganho com a indústria da insegurança e do medo. A insegurança alimenta o medo e o problema é que a alternativa à insegurança não é a bênção da tranquilidade, mas a presença do tédio (Bauman, 2009). 


\subsection{Efeitos do "Narcisismo", do "Consumismo" e do "Modelo Tecnológico"}

Com base em alguns autores (Baudrillard, 2007; Bauman, 2001, 2004; Costa, 2003; Lipovetsky, 2004; Sá, Mattar e Rodrigues, 2006), escolhemos três fenômenos importantes - o "consumismo", o "modelo tecnológico" e o "narcisismo moderno" - enquanto consequências das condições socioculturais e econômicas atuais, que possuem, segundo esses autores, correspondência com a brevidade e o descompromisso dos vínculos amorosos na contemporaneidade e, por isso, foram selecionados. A nossa intenção será a de demonstrar como tais fenômenos se convertem em valores culturais, interferindo em padrões de comportamento e na construção dos relacionamentos.

Para tanto, partiremos do princípio de que as diversas formas de se estabelecer uma cultura são as diversas formas de respostas encontradas pelos grupos sociais aos grandes problemas que envolvem a humanidade (Langendorff, 2007). Para além de um conjunto de regras e leis, trata-se de um conjunto de elementos portadores de sentido, através dos quais podemos elaborar nossas experiências, ou seja, pensá-las, assimilá-las, dar-lhes o lugar e o peso necessários, avaliá-las e, finalmente, compreendê-las. Através desse capital significante, desse sistema simbólico de representações, como aponta Langendorff (2007), nossas experiências se tornam inteligíveis para nós mesmos e para os outros.

No entanto, de acordo com Linton (1999), o indivíduo não é passivo nessa dinâmica. Por meio de suas necessidades, de sua capacidade de pensar, de sentir e agir disponibiliza formas independentes de se relacionar com a cultura e de criá-la, porque as circunstâncias do mundo são dinâmicas, mudam perpetuamente, de onde também surgem as necessidades de mudanças. As inovações sociais são produtos de um problema, de um sofrimento, de experiências novas vividas por um ou mais indivíduos, que criativamente encontram saídas para esses problemas. A realidade externa exerce uma influência diretriz sobre a constituição de modelos de comportamentos, mas o indivíduo reage a elas conforme seu conjunto de normas e valores já interiorizados. Assim, os sistemas de valores podem ser concebidos como resultado da interação do indivíduo com o ambiente, de onde advém a criação de um sistema de normas de conduta e se desenvolve o processo de transmissão das mesmas (Linton, 1999).

A cultura, portanto, como afirmou Freud (1930/2006) e os últimos autores, emana de um resultado da interação dos indivíduos com as condições sociais e econômicas, e surge enquanto consequência da consonância do conjunto indivíduo-sociedade. É desse modo que a cultura particularmente nos interessa, porque exerce uma função intermediária entre o 
indivíduo e o meio, influenciando diretamente na constituição subjetiva e nos padrões de sociabilidade.

Dessa forma, as mudanças na cultura têm implicações nas formas como a subjetividade é construída (Salles, 2005). Concebemos como subjetividade um constructo que representa a constituição psíquica de cada sujeito, formada num processo intersubjetivo (Freud, 1921/2006; Kaës, 2005ab, Ogden, 1996), sujeito a influências de circunstâncias históricas, culturais e sociais, nas quais o indivíduo está inserido, bem como através das experiências particulares que ele vivencia no interior dessa cultura (Berger \& Luckmann, 2002; Leontiev, 1978; Vygotsky, 1993). Para Salles (2005), a subjetividade só pode ser compreendida como produto das relações e mediações sociais, processo em que o indivíduo se apropria da realidade externa, tornando-a subjetiva, e onde o psiquismo é mediatizado pelas relações sociais.

Isso posto, analisaremos primeiramente o fenômeno do "consumismo". De acordo com Bauman (2001), a sociedade, com sua nova modalidade de capitalismo, não mais se organiza em torno de produtores, mas de consumidores. Para produtores, havia regras específicas: era necessário um mínimo para sobrevivência e um máximo com o que se pudesse sonhar, desejar e perseguir, contando com a aprovação social das ambições. A vida organizada em torno de consumidores, por outro lado, não possui normas: é orientada por desejos sempre crescentes e efêmeros.

Com o passar dos tempos, o consumismo se transformou em um vício que, antes de ser puro vício, se apresenta como um ritual "feito à luz do dia para exorcizar as horrendas aparições da incerteza e da insegurança que assombram as noites" (Bauman, 2001, p. 96). Esse autor explica, entendendo tal tipo de comportamento também como uma construção cultural, que é como se houvesse nesse fenômeno a ideia de poder se conquistar, por meio da aquisição de bens materiais, alguma segurança ou forma de conforto "contra a incerteza aguda e enervante e contra um sentimento de insegurança incômodo e estupidificante" (p. 95), próprios da contemporaneidade.

Em decorrência, aos moldes de Freud (1930/2006) e sem ter essa pretensão, Bauman (2001) percebe no consumismo um tipo de organização subjetiva em função de um mal-estar social que visa a aplacar angústias contemporâneas. Porém, os confortos esperados nesse tipo de organização não duram, porque os valores que poderiam ser adquiridos nessa espécie de compra não passam de valores de mercado, de troca, de circulação ou que perecem, segundo o autor. Da mesma forma, de maneira geral, a cultura atual não pode ser mais considerada como aquela de acúmulo e de aprendizado, mas como uma "cultura do desengajamento, da 
descontinuidade e do esquecimento" (p. 83) e que, por isso mesmo, não providencia aos indivíduos suportes sólidos para a estruturação da identidade.

A lógica de uma sociedade do consumismo segue um princípio que prioriza a venda de signos prontos, a acumulação de "signos de felicidade" e não favorece o simbolismo, a transformação própria do simbólico, concorda Baudrillard (2007). Na lógica do consumo, encontram-se ausentes os valores simbólicos de criação. "O objeto perde sua finalidade objetiva e a respectiva função, tornando-se o termo de uma combinatória muito mais vasta de conjuntos de objetos, em que seu valor é de relação" (p. 120).

A circulação, a compra, a venda, a apropriação de bens constituem hoje uma linguagem e um código, por cujo intermédio toda a sociedade se comunica (Baudrillard, 2007). Trata-se do "modo específico de passagem da natureza à cultura de nossa época" [itálicos nossos] (p. 80), em que prevalece a lógica da mercadoria que regula não só os

processos de trabalho e os produtos materiais, mas a cultura inteira, a sexualidade, as relações humanas e os próprios fantasmas e pulsões individuais. Tudo foi reassumido por esta lógica, não apenas no sentido de que todas as funções, todas as necessidades se encontram objetivizadas e manipuladas em termos de lucro, mas ainda no sentido mais profundo de que tudo que é espectacularizado, quer dizer, evocado, provocado, orquestrado em imagens, em signos, em modelos consumíveis [itálicos nossos] (Baudrillard, 2007, p. 205).

Concluindo, hoje não só o poder de obtenção de um objeto, mas principalmente o poder de trocá-lo por um outro novo é supervalorizado. Garante reconhecimento social pelo poder de compra implícito, além de promessas de felicidade, de aliviar as angústias, as tristezas e as dificuldades do viver. Essa lógica cultural do consumismo já contaminou todo o cenário social, e isso significa dizer que o ser humano tem confundido o seu próximo com um objeto: do mesmo modo como hoje se escolhe outro aparelho celular, nas "vitrines" das noites, das festas e das baladas, o mesmo princípio se aplica.

Com relação ao segundo fenômeno, o "modelo tecnológico", Sá, Mattar e Rodrigues (2006) salientam que todas as formas de relacionamento na contemporaneidade estão marcadas pela solidão e pela tentativa de controlá-la através da disponibilização do outro. Apontam que as queixas pela forma como se dão os relacionamentos amorosos, atualmente, avessos ao compromisso e à previsibilidade, têm por pano de fundo uma sociedade cujo modelo de sociabilidade se ancora no da instrumentação técnica, em que o homem se desvela a si próprio e ao outro como "fundo de reserva", disponível ao uso, meio para um fim. Baseando-se em Heidegger, a hipótese desses autores é a de que

as raízes sobre as quais se situava a nossa civilização, foram definitivamente destruídas pela era tecnológica, que afastou o homem de suas referências ancestrais, à medida que o 
aproximou de uma única forma de compreensão do real, baseada no desejo de controle e na possibilidade de mensuração. (Sá, Mattar \& Rodrigues, 2006, p. 122).

Esses estudiosos entendem que o desenraizamento sofrido pelo homem na modernidade progrediu à medida que o homem respondeu à ideia de controlar as relações, assim como as demais atividades de sua vida na era da técnica. O homem então passou a estabelecer uma relação utilitarista com tudo que o cerca, o que o tornou apartado das experiências coletivas, das tradições religiosas e familiares.

Na visão de Lipovetsky (2004), esse fenômeno se manifesta uma vez que, na hipermodernidade, o conjunto de crenças tem por base uma movimentação constante. "Na hipermodernidade, não há escolha, não há alternativa, senão evoluir, acelerar para não ser ultrapassado pela 'evolução': o culto da modernização técnica prevaleceu sobre a glorificação dos fins e dos ideais" (p. 57). De acordo com o autor, a lógica se explica porque, diante de um futuro imprevisível, mais se sente que ele precisa ser mudado, reinventado e flexível. A cultura, por sua vez, incorporou a crença do "quanto mais rápido melhor": quanto maior for o desempenho, a inovação e a flexibilidade, mais está o indivíduo adaptado à sociedade. Tratase do modelo de funcionamento do computador, que consagra um pouco de tempo a cada uma das tarefas que realiza simultaneamente (Tisseron, 2008). Resta saber, contudo, como propõe Lipovetsky (2004), se esse processo não tende a transformar a vida em algo sem propósito e sem sentido.

Quando a leitura era o suporte privilegiado do conhecimento, era difícil fazer várias tarefas ao mesmo tempo, segundo Tisseron (2008). Hoje em dia, o modelo de realizar uma única tarefa da melhor maneira possível não é mais valorizado, mas o contrário, porque na cultura da escrita as proposições ou questões eram colocadas com muito cuidado e da mesma forma eram respondidas, buscando-se o máximo da reflexão. Era preciso pesar os prós e os contras, antes de tomar uma posição, porque, de acordo com o autor, em tempos antigos esta parecia ser a melhor forma de administrar o futuro: nada era pior do que se encontrar em uma situação em que era preciso romper um laço com alguém. A escolha era importante - de um cônjuge, de uma profissão, de um sindicato, de um partido - porque era para a vida toda. Entretanto, isso estava dentro de uma lógica de que os opostos se excluem: hoje eles coexistem, de sorte que as possibilidades de mudanças de crenças e de escolhas são menos contrastantes, por isso também menos preocupantes e levadas muito menos a sério - seria possível acrescentar. 
Na cultura do virtual, os novos recursos tecnológicos colocam o indivíduo em contato com o outro com a mesma facilidade que os retira dele. Nos bate-papos da Internet, é possível se conectar e se desconectar com um clique, sem dar a menor explicação, e os nossos avatares podem simplesmente ser esquecidos sem nenhuma prestação de contas. Oposta à necessidade de se preocupar com as relações no futuro, entramos numa cultura que dá margem à lógica do descompromisso, observa Tisseron (2008). E podemos deduzir que essa facilidade e leveza sem consequências que a tecnologia proporciona, no contato com o outro, promove uma crença de que, desde que os relacionamentos atendam aos interesses pessoais, podem ser superficiais e efêmeros, uma vez que o fim não é o vínculo, mas o próprio eu: um sucesso, uma conquista profissional, amorosa ou um reconhecimento social. Em nossa cultura, ter mil amigos no "Facebook" é valorizado, porque dá a aparência de o indivíduo ser influente, interessante e bem-sucedido. O mito subjacente é o de que não "precisamos dos outros para ser felizes", já que, com o advento do individualismo, a lógica se trasladou para as conquistas em nível pessoal, valendo inclusive a disponibilização do outro para alcançá-las. Nesse contexto, Birman (2011) se questiona sobre as possibilidades da existência da solidariedade e mesmo da alteridade, em uma sociedade onde o sujeito "referido sempre ao próprio umbigo e sem poder enxergar um palmo além do próprio nariz" (p. 25) encara o outro apenas como um objeto para seu usufruto. Ainda acredita que, apoiados no ideal de autossuficiência e de onipotência, os sujeitos contemporâneos criam a ilusão de que não precisam de ninguém além de si mesmos.

Dessa maneira, o sujeito vive permanentemente em um registro especular, em que o que lhe interessa é o engrandecimento grotesco da própria imagem. $\mathrm{O}$ outro lhe serve apenas como instrumento para o incremento da autoimagem, podendo ser eliminado como um dejeto quando não mais servir para essa função abjeta. (Birman, 2011, p. 26).

O individualismo, nascido com a modernidade, apesar de ter promovido a ampliação de um espaço de escolha e de possibilidades diferenciadas de construções subjetivas, também faz declinar as forças interiores do indivíduo, conforme visto (Lipovetsky, 2004). "Quanto mais o indivíduo é socialmente cambiante, mais surgem manifestações de esgotamentos e 'panes' subjetivas. Quanto mais ele quer viver intensa e livremente, mais se acumulam os sinais do peso de viver" (Lipovetsky, 2004, p. 84). O homem descontraído está igualmente desarmado, à mercê das desordens narcísicas, sem forma e intermitentes. Entraremos, a partir de agora, no campo do fenômeno do "narcisismo". 
Aplicando os princípios de Freud (1930/2006) à nossa época, podemos supor, assim como Costa (2003), que, em face das instabilidades e efemeridades que assolam o mundo, organizar-se em torno de uma defesa narcísica é uma saída, uma solução também cultural.

A cultura do narcisismo fundamenta-se basicamente na realidade de um mundo exterior que se apresenta como cada vez menos durável, comum e público, onde as associações humanas e as memórias coletivas se encontram cada vez mais problemáticas (Lasch, 1983). Esses sentimentos intensificam o medo da separação, ao mesmo tempo em que enfraquecem os recursos psicológicos que tornam possível enfrentar tal medo de forma realista. Esse autor explica que os processos de separação e de morte só são suportáveis porque o mundo preenchido de cultura humana restaura o sentido de vinculação original em uma nova base. Entretanto, mediante condições de existência que enfraquecem os recursos para lidar com as perdas, o medo da separação torna-se quase esmagador e a necessidade de ilusões passa a ser, consequentemente, mais intensa do que nunca.

Para Costa (2003), o "narcisismo" contemporâneo não deve ser visto como causa dos tipos psicológicos e sim como "efeito de traumatismo", representando uma estratégia de sobrevivência. Assim, define o "narcisismo moderno", nosso terceiro fenômeno, como um mal-estar cultural atual, mas que não deve ser entendido como um "excesso qualquer de narcisismo". Segundo ele, o homem narcísico hoje não sofre por querer "gozar demais", como propunha Lasch (1983). O “narcisismo moderno é um narcisismo regenerador” (p. 169), pois há nesse processo uma relação violenta entre a sociedade contemporânea e esse novo indivíduo, que procura se recuperar dela, investindo narcisicamente em si. Nas palavras do autor:

A devastação da vida privada, tão bem descrita por Lasch, excedeu o que ele pôde supor. Tornando o corpo e o sexo objetos de consumo, o capitalismo moderno obrigou o indivíduo a adotar uma "estratégia de sobrevivência narcísica" que pouco tem a ver com o prazer e muito com a dor. O indivíduo moderno é um indivíduo violentado, antes de ser narcisista. É esta violência que explica seu narcisismo e as aparências "patológicas" que ele assume. Seu corpo e seu sexo monopolizam a libido objetal porque, como o "órgão lesado", ou "hipocondríaco" de Freud, tornaram-se fontes de sofrimento, dor e ameaça de morte para o EU. (Costa, 2003, p. 169).

Portanto, de acordo com Costa (2003), o fenômeno do "narcisismo moderno" associase a um mal-estar cultural e a uma tentativa de se recuperar dele, assumindo os moldes de um mecanismo de sobrevivência. Lipovetsky (2004) parece concordar, pois, para ele, o "narcisismo" em tempos de hipermodernidade se mostra preenchido por ansiedade e tomado pelo receio e pela angústia, oposto à época em que imperava o gozo e a libertação, provavelmente na época em que Lasch (1983) o descreveu. 
Da mesma forma que Costa (2003), a leitura de Lipovetsky (2005) sobre o narcisismo contemporâneo inclui uma busca por proteção, um mecanismo de sobrevivência. Ele também percebe, implícito nesse mecanismo, uma necessidade de se alcançar um estado de desapego, de enxugar toda a tensão emocional e de atingir um estado de indiferença, procurando a proteção dos próprios impulsos que arriscam ameaçar o equilíbrio interior. No campo dos relacionamentos encontramos, como resultado desse fenômeno, o medo de se decepcionar, o medo das separações dolorosas, das paixões descontroladas e a aspiração à independência afetiva (Lipovetsky, 2005).

Concluindo, trata-se de uma sociedade em que o indivíduo se sente exposto e vulnerável com poucos recursos para lidar com todo o tipo de emoção. Lipovetsky (2005) constata que o processo de personalização agencia um tipo de personalidade cada vez menos capaz de enfrentar a prova do real. Destaca o enfraquecimento do poder organizador que o coletivo tinha sobre o individual, promovido pelo fenômeno da individualização, mas também da desvalorização da tradição, acarretando num individuo desinserido do grupo, privado dos esquemas sociais estruturantes que o "dotavam de forças interiores que lhe possibilitavam fazer frente às desventuras da existência” (Lipovetsky, 2005, p. 84).

A cultura hipermoderna se caracteriza pelo enfraquecimento do poder regulador das instituições coletivas e pela autonomização correlativa dos atores sociais em face das imposições do grupo, sejam da família, sejam da religião, sejam dos partidos políticos, sejam das culturas de classe. Assim, o individuo se mostra cada vez mais aberto e cambiante, fluido e socialmente independente. Mas essa volatilidade significa muito mais a desestabilização do eu do que a afirmação triunfante de um indivíduo senhor de si mesmo. O testemunho disso é a maré montante de sintomas psicossomáticos, de distúrbios compulsivos, de depressões, de ansiedades, de tentativas de suicídio, para nem falar do crescente sentimento de insuficiência e autodepreciação. (Lipovetsky, 2005, p. 83).

\subsection{Relacionamentos Contemporâneos}

Face ao panorama apresentado, nosso foco será demonstrar a forma com que as incertezas e instabilidades, juntamente com a valorização da democracia e da liberdade, podem interferir na configuração dos relacionamentos ${ }^{8}$ na atualidade.

Para Bauman (2004), é particularmente inquietante o destino dos laços humanos, visto que, num mundo repleto de sinais confusos, incertos, propensos a mudar com rapidez e de

\footnotetext{
${ }^{8}$ A palavra "relacionamento" se diferencia da de "vínculo", conceitualmente, principalmente porque esta última leva em consideração o aspecto intersubjetivo da ligação. Contudo, essa diferenciação será abordada somente no capítulo III: "Da Intersubjetividade à Transmissão Psíquica", porque, para a compreensão dos resultados desta tese, essa diferenciação será importante. Por ora, quando utilizamos "vínculo" estamos sendo coerentes com sua conceitualização, mas seu emprego não interfere no entendimento do que propõe este capítulo.
} 
forma imprevisível, a sensação decorrente é a de que é preciso aprender a não ter ligações indissolúveis e definitivas. Quando tudo é passageiro e nada é mais eterno, a instabilidade e a efemeridade também se instauram no âmbito dos relacionamentos. De acordo com esse autor, nossos contemporâneos estão

desesperados por terem sido abandonados aos seus próprios sentidos e sentimentos facilmente descartáveis, ansiando pela segurança do convívio e pela mão amiga com quem possam contar num momento de aflição, desesperados por "relacionar-se". E, no entanto desconfiados da condição de "estar ligado", em particular de estar ligado "permanentemente", para não dizer eternamente, pois temem que tal condição possa trazes encargos e tensões que eles não se consideram aptos nem dispostos a suportar, e que podem limitar, severamente a liberdade de que necessitam para - sim, seu palpite está certo - relacionar-se... (Bauman, 2004, p. 8).

Nesse contexto, ainda segundo o autor, amar torna-se cada vez mais difícil e raro, porque se espera desfrutar de um relacionamento sem os seus momentos amargos e dolorosos: "comer o bolo e ao mesmo tempo conservá-lo" (Bauman, 2004, p. 9). Baseando-se em Lévinas, concebe "Eros" como aquilo que promove a relação com a alteridade, com o mistério e com o futuro e, assim, o amor nos expõe inevitavelmente à vulnerabilidade. Todavia, em função do abordado, é possível deduzir que essa vulnerabilidade se tornou sinônimo de risco de alta intensidade em uma sociedade individualizada, cujas responsabilidades tendem a cair sobre os ombros dos indivíduos, que, frágeis, tendem a voltar-se para si mesmos.

Portanto, Bauman (2004) percebe a fraqueza, a debilidade e a vulnerabilidade das parcerias pessoais e as atribui a uma inédita fluidez e transitoriedade em construção, que "marcam todas as espécies de vínculos sociais que, uma década atrás, combinaram-se para constituir um arcabouço duradouro e fidedigno dentro do qual se pôde tecer com segurança uma rede de interações humanas" (pp. 112-113).

Entretanto, Lipovetsky (2004), que não pretende tomar a parte pelo todo, entende que, na verdade, coabitam "duas tendências: a que acelera os ritmos tende à desencarnação dos prazeres; a outra, ao contrário, leva à estetização dos gozos, à felicidade dos sentidos, à busca da qualidade no agora" (p. 81). A efemeridade com que alguns relacionamentos são construídos na contemporaneidade não o assusta, porque compreende esse fenômeno como apenas mais uma modalidade de usufruir dos prazeres da vida, possibilitada pelo declínio das normas tradicionais rígidas.

Apesar da virtualização da comunicação, por exemplo, o autor acima nota que a grande maioria ainda aprecia eventos ao vivo, as festas coletivas e as saídas com os amigos. $\mathrm{O}$ indivíduo hipermoderno não pode ser definido de modo simplista, porque uma gama de 
possibilidades provoca a "despadronização dos prazeres", onde o "extremo é apenas uma das vertentes da ultramodernidade" (Lipovetsky, 2004, p. 82). O mais importante, para esse autor, é que a sensibilidade em relação ao outro não foi abolida, nem as aspirações de uma vida equilibrada no nível sentimental.

Justo (2005) define como "amor confluente" este que é o "resultado dos avanços das conquistas de maior igualdade nas relações de gênero, da liberdade quanto às escolhas de parceiros e interrupções de relacionamentos conjugais e é também expressão da maior mobilidade espaço-temporal do sujeito na contemporaneidade" (Justo, 2005, p. 75). Enfatiza que o "ficar", o mais passageiro dos relacionamentos amorosos, inscreve-se nesse paradigma da contemporaneidade que privilegia a

compressão do tempo, a expansão das fronteiras geográficas, econômicas, políticas e psicossociais, o nomadismo, o desamparo, o desprendimento, o isolamento, o individualismo, o hedonismo, o narcisismo, o desapego, o jogo, o acaso e tantas outras condições produtoras de uma subjetividade oscilante e intermitente (Justo, 2005, p. 76).

Cremos que Giddens (2007) é capaz de captar a essência do que estes últimos autores expuseram, ao desenvolver o conceito de "relacionamento puro". Tendendo a ser a forma predominante de convívio humano, segundo o autor, nesse tipo de relacionamento se entra pelo que se pode ganhar, de acordo com o grau de satisfação que pode obter, pois é "baseado na comunicação emocional, em que as recompensas derivadas de tal comunicação são a principal base para a continuação do relacionamento" (p. 70), e não mais as normas rígidas tradicionais. É essa liberdade em torno de sua construção, e a necessidade de estar em permanente construção, que o leva a ser caracterizado como aquele que pode ser rompido por qualquer um dos parceiros, a qualquer tempo (Giddens, 2007), trazendo implicações sérias para o vínculo amoroso. Trata-se de uma liberdade ainda interpretada por Bauman (2004) como aquilo que assusta nesse tipo de união e que leva ao medo da dependência, porque, muito provavelmente, esse autor observa igualmente o funcionamento paralelo dos relacionamentos efêmeros que assim são, não porque são "puros", mas em que a insegurança do casal, diante dos novos padrões fluidos de se relacionar, não permitiu o seu aprofundamento. E isso é extremamente importante, uma vez que denuncia, também muito provavelmente, um sintoma de uma época de transição. Ou seja, quando o fenômeno dos "relacionamentos puros" ainda dá margem aos relacionamentos efêmeros, porque, nesse caso, a liberdade ainda pode ser confundida com descaso e insensibilidade. Onde se esperava compromisso e dependência, encontra-se hoje o estado instável de conhecer o outro para 
somente depois descobrirem juntos como e o quando pretendem construir/investir no vínculo amoroso.

Algumas características específicas fazem o "relacionamento puro" se distanciar do padrão de relacionamento do tipo tradicional: depende de processos de confiança ativa (abertura de si mesmo para o outro), da franqueza, como condição básica para a intimidade, e da democracia (Giddens, 2007). Na perspectiva do autor, um bom relacionamento realmente é aquele que se estabelece entre iguais, em que cada parte tem seus direitos e obrigações.

Num relacionamento assim, cada pessoa tem respeito pela outra e deseja o melhor para ela. (...). A conversa, ou o diálogo, é o que basicamente faz o relacionamento funcionar. (...). E a confiança tem de ser trabalhada; não pode ser simplesmente pressuposta. Finalmente, um bom relacionamento é aquele isento de poder arbitrário, coerção e violência. (Giddens, 2007, p. $71)$.

É dessa forma que o autor compreende que os relacionamentos na atualidade seguem os valores da política democrática: igualdade de direitos e de responsabilidade; o respeito mútuo; a presença do diálogo aberto como uma propriedade essencial da democracia; e a ausência de poder autoritário. Por isso, considera que, se realmente esses princípios forem aplicados aos relacionamentos, pode-se pensar em uma "democracia das emoções na vida cotidiana" (Giddens, 2007, p. 72), e que esse tipo de democracia lhe parece tão importante quanto a democracia pública para o aperfeiçoamento da qualidade de nossas vidas.

Portanto, podemos enxergar duas vertentes para compreender os relacionamentos amorosos efêmeros, na contemporaneidade: ou são "puros" e, por isso, sinceros, verdadeiros e passageiros, porque a honestidade dá lugar ao imperativo da união, baseando-se na suposição de que deve durar enquanto esta for prazerosa e significativa; ou são simplesmente efêmeros, porque o casal, ou uma das partes, não suportou o grau de liberdade que esse novo tipo de relacionamento requer, ou qualquer outra das características do "relacionamento puro", como a democracia, a necessidade de aceitar a diferença, ou mesmo o respeito que exige etc. De fato, sem os padrões normativos organizando as relações, a vulnerabilidade inerente que supõe a entrega do amor se torna mais complexa e angustiante de ser vivida, apesar da liberdade e da democracia serem, sem dúvida, valores apreciados nesse âmbito. Novamente, é o paradoxo a que estamos expostos, na contemporaneidade.

Entretanto, é essencial ainda ressaltar que a opção pelo não compromisso em um vínculo amoroso não deve ser entendida necessariamente como sinônimo de relacionamentos efêmeros ou passageiros. A despeito de o serem, em muitos casos, há aqueles que mantêm um vínculo amoroso não compromissado por um tempo significativo, caracterizado pelo fato de não haver promessas de fidelidade entre os parceiros: ambos estão cientes de que pode haver 
relacionamentos paralelos - e isso está acordado. Dessa maneira, definimos como vínculo amoroso não compromissado aquele que abarca as características de um "relacionamento puro" (Giddens, 2007), em que está acordada a não fidelidade, mas que não implica necessariamente ser breve, ainda que em muitos casos o seja.

Finalizando essa temática, pensamos ser importante apresentar as configurações contemporâneas da família. Embora essa temática não esteja diretamente ligada com o fenômeno de nosso estudo, o cenário da família contemporânea, suas transformações e suas representações permeiam o universo de nossos contemporâneos. Giddens (2007) destaca que há uma "revolução global em curso no modo como pensamos sobre nós mesmos e no modo como formamos laços e ligações com outros" (Giddens, 2007, p. 61) e atribui as mudanças no seio da família à separação entre a sexualidade e a reprodução. A sexualidade, que costumava ser definida estritamente em relação ao casamento e à legitimidade, atualmente tem pouca conexão com eles. Inclusive, a crescente aceitação da homossexualidade não deve ser vista somente como resultado da tolerância liberal, frisa o autor, mas ainda como o efeito do entendimento de uma sexualidade que deixa de ser, por definição, dominada pela heterossexualidade.

A família contemporânea, para ele, ainda se organiza em torno da amizade e dos laços democráticos. Observa que a persistência da família tradicional seria inquietante, já que a igualdade de direitos entre homens e mulheres e a educação das mulheres são as vias mais importantes de implementação da democracia e do desenvolvimento econômicos, nos países mais pobres. Por outro lado, acredita que muitas das mudanças que a família está experimentando são problemáticas e difíceis, sobretudo pela perda dos princípios tradicionais que facilitavam o exercício dos padrões de comportamento.

Para Roudinesco (2003), a família contemporânea compreende simplesmente a união de dois indivíduos em busca de relações íntimas ou realização sexual. Observa que o casamento perdeu todo seu valor simbólico de outrora, tornando-se apenas um tipo de união, mais ou menos duradoura, que protege os cônjuges de eventuais desordens do mundo. Os filhos, nesse novo modelo, são cada vez mais concebidos fora dos laços matrimoniais e assistem às núpcias e aos divórcios de seus pais. Em lugar da divinização, a família contemporânea pretende-se frágil, neurótica, consciente de sua desordem e assemelha-se a "uma rede assexuada, fraterna, sem hierarquia nem autoridade, na qual cada um se sente autônomo ou funcionalizado" (p. 155).

Além dessas mudanças de valores, compreendemos, na realidade, que a família contemporânea representa uma série de transformações que ocorreram, mas que ainda 
conjuga o modelo tradicional de família com a pluralidade das novas configurações. De maneira geral, a família hoje deve ser concebida de forma mais ampliada, podendo incluir novos parceiros e filhos/irmãos agregados (Gomes, 2009), além de abranger uma maior complexidade nas relações e em sua dinâmica, não somente porque pode incluir membros impensáveis no passado, mas em função da queda do poder hierárquico sobre as organizações rígidas.

A aspiração pela felicidade oriunda da reciprocidade amorosa, característica da modernidade, também permanece na família contemporânea, segundo Moguillansky e Nussbaum (2009), mas agora é buscada através de novas configurações familiares, impensáveis na era moderna. A abertura para a multiplicidade, no âmbito da família, tem propiciado o aparecimento das novas configurações e o seu reconhecimento social e jurídico.

Moguillansky e Nussbaum (2009) salientam, no entanto, que a verdadeira essência da pós-modernidade não está nas reconfigurações familiares, já que estas ainda reivindicam a aspiração moderna de felicidade através da reciprocidade amorosa, o que pensam conquistar nessa nova busca por outros vínculos. Porém, aqueles que optam por viverem sozinhos, segundo os autores, personificam o desencanto do casal unido pelo amor, inventado pela modernidade, pois estes não creem mais nas grandes paixões. O sentimento da pósmodernidade que assumem e refletem é o de não compactuar com a ilusão das certezas, das promessas e das expectativas que a modernidade pregava e almejava. Para os autores, esse novo modo de pensar pode ser caracterizado como o "pensamento da incerteza" e o critério subjacente é o da operatividade e não o juízo sobre o verdadeiro ou justo.

\section{As raízes do mal-estar no mundo contemporâneo e o psiquismo}

Neste momento, partiremos para as explicações de um teórico psicanalista, Kaës, para quem todas essas condições contemporâneas de existência e as profundas mudanças que ocasionaram têm consequências para o psiquismo. Esse autor nos ajudará a refletir, de maneira mais profunda, como essas mudanças intervêm na organização psíquica e subjetiva de cada sujeito.

Retomando o exposto, em poucas palavras, podemos concluir que a construção de valores, princípios e condutas como efeito dos fenômenos do "consumismo", "modelo tecnológico" e "narcisismo moderno" reflete organizações subjetivas que buscam se "defender" contra as incertezas que assolam o mundo. Esses valores são paradoxais e 
descontínuos, baseados em leis de troca do mercado, na imprevisibilidade e na necessidade de controle, em face de um dinamismo sem precedentes, de sorte que perecem e não favorecem a transformação própria do simbólico.

Trata-se de uma sociedade onde nada se exclui, e a liberdade e a ilimitada variedade de possibilidades permitem a sensação de estar solto e sem qualquer controle, sem qualquer norma que garanta um mínimo sobre o destino das relações, igualmente soltas. Uma sociedade onde os interesses pessoais sobressaem aos do grupo, onde o individualismo assume o lugar das grandes narrativas, da memória coletiva, do bem comum, público e durável. Em uma palavra, onde o ser humano, através das novas organizações subjetivas, busca proteção. Todo o tipo de "solidez" foi trocado por "fluidez" (Bauman, 2001, 2004, 2009), e não existem mais normas ou contratos separando o legítimo do não legítimo, o seguro do não seguro, o justo do não justo. Caindo as "grandes certezas" que davam rumo e sentido ao mundo, diante de um futuro imprevisível, cada vez mais se sente que tudo precisa ser móvel, flexível e reinventável, como sublinhou Lipovetsky (2004).

Para Kaës (2005b), na pós-modernidade, tudo se equivale, tudo pode ser trocado, tudo é indiferente ou indiferenciado, porque a cultura se caracteriza pela recusa de todo o tipo de cristalização dos códigos e de ancoragem. O valor de liberdade que sustenta essas recusas por normas padronizadas levou à complexidade de um pensamento não-linear capaz de admitir paradoxos e incertezas, além da instabilidade entre a ordem e a desordem. E será sobre essas bases que ele seguirá com sua análise.

Kaës (2005b) assinala que Winnicott (1975) qualificava a experiência cultural como uma extensão da noção de fenômeno, objeto e espaço transicional. Ao utilizar a palavra cultura, Winnicott (1975) pensava na tradição que herdamos, em algo como um lote comum da humanidade ao qual todos podem contribuir e de onde podemos retirar alguma coisa, se tivermos um lugar para colocar o que encontramos. No entanto, Kaës (2005) entende que o mal-estar atual reflete a dificuldade de constituirmos esse "lugar para colocar aquilo que encontramos" (Winnicott, 1975), em razão das múltiplas crises que atravessam a contemporaneidade e nos ameaçam, notadamente através das instituições que nos organizam.

A leitura psicanalítica de Kaës (2005ab), procurando articular o social ao psíquico, parte do movimento de desestabilização que se iniciou com a modernidade. De acordo com o autor, como um modo de civilização que se opunha ao mundo da tradição, a modernidade criou, em última instância, uma cultura crítica com relação às crenças e certezas sustentadas pelos mitos, pela religião, pelos ideais coletivos e pelas hierarquias sociais, os quais estabeleciam um sistema estável de sentidos e valores. Por consequência, toda sua análise será 
em função de defender a existência de falhas nas "garantias ${ }^{9}$ metassociais" que se refletem em falhas nas "garantias metapsíquicas”, como será explicado.

Com base em Freud (1930/2006), é levando em consideração esse contexto que o autor concebe o nascimento de dificuldades em torno da estruturação do psiquismo na atualidade, porque, segundo Kaës (2005b), o mundo tradicional era o responsável pelas "garantias metassociais" da sociedade, ou seja, o responsável por um "enquadramento da vida social e cultural, os grandes processos de regulação da vida coletiva: mitos e ideologias; crenças e religiões; autoridades e hierarquia; instituições culturais e políticas"10 (p. 243, tradução livre do autor), as grandes estruturas de regulação que asseguram a ordem social e cultural numa sociedade, mas também a organização da estruturação psíquica (Kaës, 2009). E, nesse sentido, na contemporaneidade pelo oposto, perdendo-se em valores e princípios tradicionais, institucionalizados e hierarquizados, perdemos também em organizadores da vida psíquica, conforme o autor.

Não se trata de cedermos à ilusão da morte das ideologias, ele afirma, mas de entendermos que o que desapareceram foram as formas instituídas das ideologias e dos mitos, e que essa perda da estabilidade em torno de crenças e valores influencia na estruturação do psiquismo. Vale ressaltar que a nossa ideia aqui não é a de adentrar num espaço de idealização das estruturas do passado, nem a do autor, supomos, mas de compreender movimentações socioculturais e suas possíveis consequências para a organização do psiquismo, a vulnerabilidade e a fragilidade do indivíduo contemporâneo, tão bem frisadas anteriormente.

Logo, seguindo o pensamento do autor, esses enquadramentos metassociais se definiam por garantir uma estabilidade às formações sociais e por adquirir uma legitimidade incontestável. Quando as "garantias metassociais" passaram a se mostrar falhas, ou quando se transformaram sob o efeito da industrialização, da urbanização e dos movimentos migratórios induzidos pelas mutações, as sociedades industriais passaram a sofrer os efeitos de instabilidades graves. Quando as grandes ideologias e crenças no progresso não mais sustentaram as certezas em termos do futuro, os sistemas de representações e os valores, mas também as leis e os interditos, que regulamentam as relações sociais e interpessoais,

\footnotetext{
${ }^{9} \mathrm{O}$ termo utilizado pelo autor é "garant", que em francês significa "pessoa que responde pelos seus actos ou pelos de outrem", o que em português se refere à "pessoa ou instituição ou coisa que garante ou se responsabiliza por alguém ou algo" (Dicionário Priberam da Língua Portuguesa, recuperado em 24 de fevereiro de 2012 de http://www.priberam.pt/dlpo/default.aspx?pal=garante). Dessa forma, optamos por traduzir esse termo como "garantia", como tem sido utilizado nas traduções para o português.

${ }^{10}$ Tradução livre do autor: “ (...) les grandes structures d'encadrement de la vie sociale et culturelle, les grands processus de régulation de la vie collective: mythes et idéologies; croyances et religions; autorité et hiérarchie; institutions culturelles et politiques" (Kaës, 2005b, p. 243).
} 
tornaram-se instáveis, contraditórias e inoperantes. Desqualificaram-se, enfatiza Kaës (2005b).

Por conseguinte, entendemos que falhas nas "garantias metassociais" representam uma movimentação em torno das representações sociais que regravam as relações sociais e interpessoais baseadas na lei e nos interditos. E a relação dessas "garantias metassociais" com as "garantias metapsíquicas" é que as primeiras eram capazes de garantir as segundas: reparos identificatórios, ideais comuns, representações simbólicas e imaginárias, alianças inconscientes, pactos e contratos, todos necessários à estruturação do psiquismo (Kaës, 2005b).

Na leitura de Kaës (2005ab), em O mal-estar da civilização, Freud (1930/2006) coloca em evidência justamente a necessidade da renúncia à realização direta dos fins pulsionais para que o indivíduo possa se formar e se manter; um contrato em que o homem renuncia a uma parte da felicidade para trocá-la por segurança, conforme visto. Como Freud (1930/2006) salienta, a vida civilizada torna-se possível somente porque o conjunto é mais poderoso do que cada indivíduo particular e, principalmente, o conjunto em face de um único indivíduo. Quando o poder do coletivo se opõe à violência individual, a comunidade não somente limita os prazeres, mas se protege "contra a violência do indivíduo, impõe a necessidade e torna possível o amor" (Kaës, 2005a, p. 57). Troca parte da felicidade por segurança.

Da obra de Freud (1930/2006), o conjunto de regras que regulamenta a relação entre os homens é frisado por Kaës (2005b), porque para ele é dessa maneira que as leis e os interditos garantem não só a vida em comunidade, mas, a partir do trabalho de civilização, também a sublimação e com isso "a segurança necessária para a formação do pré-consciente, para o trabalho do pensamento e a manutenção dos vínculos" (Kaës, 2005a, p. 57). E, se tal tentativa se fizer falha, o conjunto de regras poderia ser submetido à arbitrariedade de um indivíduo psiquicamente mais forte, que regulamentaria os sentidos e pulsões instintivas ao seu próprio interesse, conforme destaca Freud (1930/2006) e como de fato ocorreu. Kaës (2005b) compreende que o texto de Freud (1930/2006) foi profético, nesse sentido, prevendo grandes desestruturações sociais e culturais, como foi o fascismo e o nazismo. Tais atrocidades só foram possíveis, observa Kaës (2005b), porque esses líderes não encontraram algo mais forte do que eles, isto é, um conjunto cultural sólido, sustentado por suas regulamentações.

Disso podemos depreender que o contrato civilizatório, composto por um conjunto de crenças e regras bem instituídas, é a base não somente para a vida em civilização, mas da possibilidade de se pensar e elaborar, trabalhar e amar. No entanto, o autor defende que esse 
contrato desde a modernidade foi sofrendo movimentações e modificações, causando desorganizações sociais e culturais e sofrimento psíquicos.

Aprofundando-nos em seu pensamento, é sobre essas bases que falhas, desregramento ou defeitos nas "garantias metassociais" se transformam em falhas ou defeitos das "garantias metapsíquicas", afetando diretamente a estruturação e o desenvolvimento da vida psíquica de cada sujeito. Ou seja, o autor propõe que movimentações em torno dos valores e crenças instituídas, das representações sociais (garantias "metassociais") interferem na manutenção estável das leis e dos interditos fundamentais e dos contratos intersubjetivos (garantias "metapsíquicas"), concebidos pelo autor como suportes para a estruturação do psiquismo. Em outras palavras, as estruturas "metassociais" sustentam as estruturas "metapsíquicas", responsáveis pelos princípios organizadores da psique individual, além das condições intersubjetivas (Kaës, 2009).

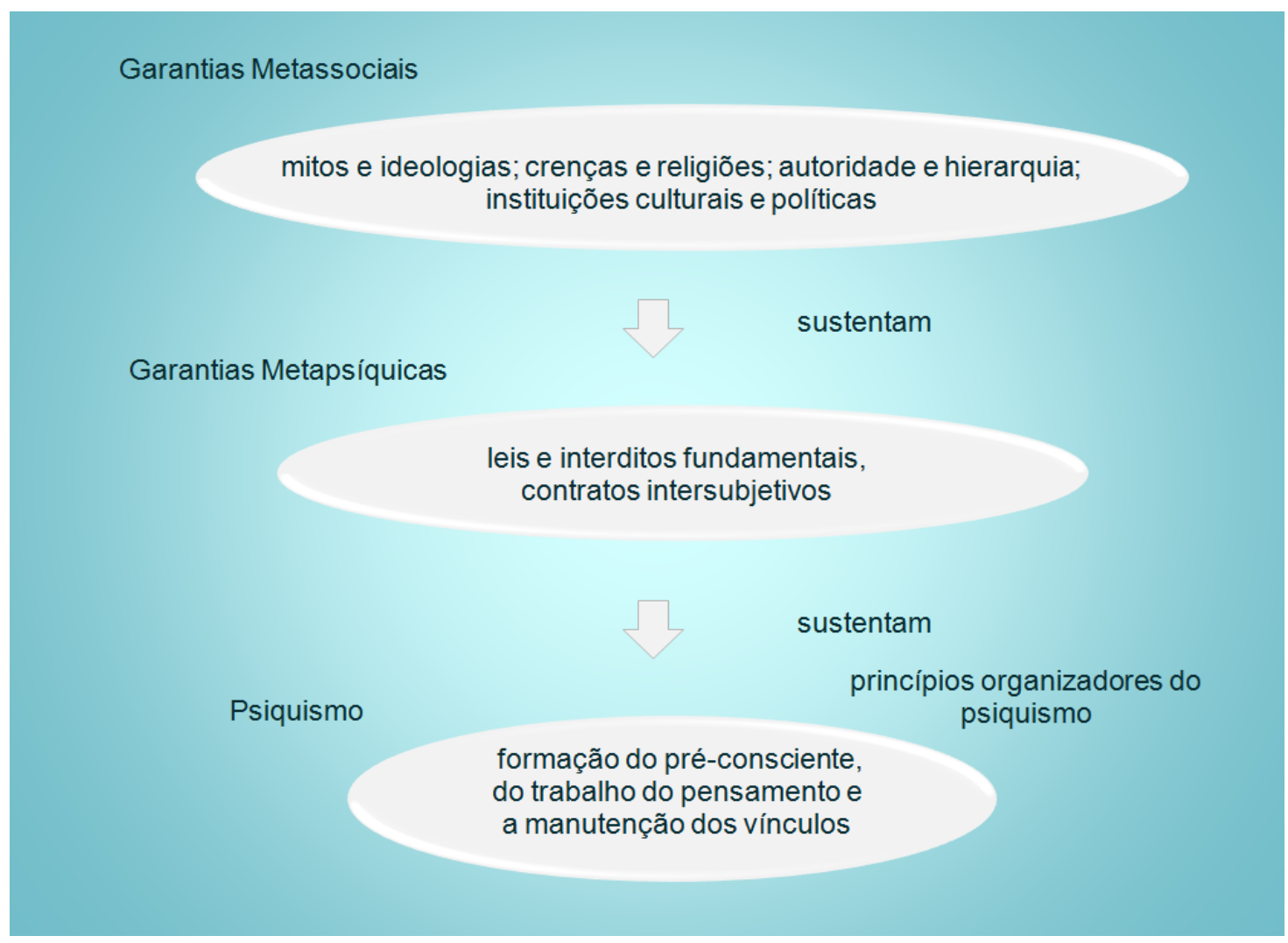

Figura 1: Demonstração esquemática da interação e formas de sustentação entre "garantias metassociais", "garantias metapsíquicas" e o psiquismo individual.

Ainda que uma parte da realidade psíquica inconsciente escape a toda determinação social ou intersubjetiva, a intenção de Kaës (2005b) é a de mostrar que a vida psíquica 
somente pode se desenvolver sobre uma base de exigência de trabalho psíquico ${ }^{11}$, que impõe ao psiquismo sua inscrição nos vínculos intersubjetivos primários e nos vínculos sociais. Assim, entende que as "garantias metapsíquicas" são as formações e os processos ambientais psíquicos sobre os quais se sustentam e se estruturam o psiquismo de cada sujeito. Essencialmente, são os interditos fundamentais e os contratos intersubjetivos que exercem a função "meta" para cada psiquismo singular e para todos os sujeitos de um conjunto. Enfatiza o autor:

O prefixo meta indica uma mudança de lugar, de condição (metabolismo), de local (metáfora) ou de nível de reflexão (metafísica, metalinguagem, metapsicologia) ou ainda a sucessão no tempo ou no espaço. O que me interessa na preposição meta são os dispositivos de fundo que enquadram os processos ou as formações que observamos. É neste sentido que eu falo da organização metapsíquica. (Kaës, 2009, p. 26, tradução livre do autor) ${ }^{12}$.

Nessa perspectiva, compreendemos que o prefixo "meta" indica justamente um posicionamento de fundo, estruturante, indicando aquilo que sustenta, garantido a existência do que ampara por sua função sustentadora. As "garantias metapsíquicas", na realidade, podem ser descritas sob diversos pontos de vistas, segundo Kaës (2005b); todavia, esse autor, que se dedicou amplamente a estudar os grupos e seus funcionamentos, escolheu descrevê-las centradas sobre os contratos, dentro dos quais estão inseridos tanto as leis e os interditos, quanto os pactos e as alianças.

As alianças, os contratos e os pactos que correspondem à estruturação do psiquismo são aquelas relacionadas ao pacto denegativo, ao contrato de renúncia à realização direta dos fins pulsionais e ao contrato narcísico. Tais "garantias metapsíquicas" são preexistentes ao nascimento de uma criança e elas a "amarram" e "reamarram" aos seus contemporâneos. Daremos ênfase a cada uma delas, na sequência.

\footnotetext{
${ }^{11}$ Kaës (2011) distingue quatro principais exigências de trabalho psíquico: a primeira é a de obrigação do sujeito de "investir o grupo com sua libido narcísica e objetal a fim de receber deste, em retorno, os investimentos necessários para ser reconhecido pelo conjunto e pelos outros como sujeito membro do grupo. Esta exigência de trabalho se forma com base no modelo do contrato narcísico descrito por P. Castoriadis-Aulagnier (1975)" (p. 125). A segunda exigência é a renúncia de identificações e ideais pessoais em prol de ideais comuns e em troca de benefícios esperados do grupo. A terceira exigência refere-se à operações de recalque, de denegação ou de rejeição para que o conjunto se forme e os vínculos se mantenham. Essas alianças inconscientes defensivas são requeridas pelo grupo e pelos interesses pessoais. A quarta exigência "se articula com os interditos fundamentais em suas relaçães com o trabalho de civilização (Kulturarbeit) e os processos de simbolização. Freud insistiu $(1927,1929)$ na renúncia mútua à realização direta dos fins pulsionais proibidos, para que se estabeleça uma "comunidade de direito" garantidora de vínculos estáveis e confiáveis" (Kaës, 2011, p. 126).

${ }^{12}$ Tradução livre do autor: "Le préfixe méta indique un changement de lieu, de condition (métabolisme), de place (métaphore) ou de niveau de réflexion (métaphysique, métalangage, métapsychologie) ou encore la succession dans le temps ou dans l'espace. Ce qui m'intéresse dans la préposition méta, ce sont les dispositifs d'arrière-fond qui encadrent les processus ou les formations que nous observons. C'est en ce sens que je parle d'organisations métapsychiques" (Kaës, 2009, p. 26).
} 
Embora o pacto denegativo tenha uma função defensiva e comporte uma deriva patológica, Kaës (2005b) salienta que ele tem a função de manter unida uma família, um grupo ou um casal, porque se trata justamente do pacto inconsciente entre os psiquismos de manter sob recalque tudo aquilo que não pode ser tolerado pelos membros da união. Assim, é um pacto organizador dos vínculos, mas de caráter defensivo (Kaës, 1991). Para o autor, todo o espaço psíquico comum e compartilhado pelos membros de uma mesma família, de um casal, de um grupo ou de uma instituição contém formações metapsíquicas desse tipo, e essas formações (pactos, acordos e alianças) são sensíveis às estruturas profundas da vida social e cultural (Kaës, 2005b).

Importante considerar, antes de seguirmos, que todas essas conceituações se apoiam num arcabouço teórico desenvolvido pelo autor ao longo de sua obra, em que Kaës (2011) supõe a existência de um campo intersubjetivo próprio às formações grupais, no qual se organiza um espaço comum, conjunto e compartilhado, que compreende a existência de processos específicos, por meio dos quais os sujeitos se constituem em termos subjetivos e também parte de seu inconsciente. De forma sucinta, de acordo com Fernandes (2004), fundamentando-se em Kaës, um grupo organiza-se a partir de alianças inconscientes, de pactos denegativos e de contratos e pactos narcísicos. Cada um deles tem o poder de reforçar certos processos, certas funções ou certas estruturas das quais os sujeitos retiram um benefício tal que a ligação os mantém unidos. Destaca a autora:

Aliança Inconsciente é pensada como uma formação psíquica intersubjetiva construída pelos sujeitos de um vínculo para reforçar, em cada um deles, certos processos, certas funções, ou certas estruturas das quais eles tiram um benefício tal que a ligação que os mantêm junto, toma para sua vida psíquica um valor decisivo. O conjunto assim ligado não tem sua realidade psíquica a não ser pelas alianças, contratos e pactos que os sujeitos estabelecem e que seu lugar no conjunto os obriga a manter. Elas estão a serviço de uma função recalcante, e, além disso, de um sobre-recalque, como se fosse um redobramento do recalque, na medida em que elas se manifestam não somente sobre os conteúdos inconscientes, mas sobre a própria aliança. (Fernandes, 2004, § 23).

Quanto ao contrato de renúncia à realização direta dos fins pulsionais, examinando mais precisamente as implicações e as consequências desse contrato apresentado por Freud (1930/2006), Kaës (2005b) explica que ele implica um processo compartilhado de correcalque (corefoulement) entre a mãe e a criança. Essa renúncia supõe uma instância de enunciação dos interditos fundamentais e a constituição do superego na criança, como herdeiro do Complexo de Édipo $^{13}$ (Freud, 1924/1969), sustentado na culpa, no caso de esses interditos serem

${ }^{13}$ O Complexo de Édipo define-se como "conjunto organizado de desejos amorosos e hostis que a criança sente em relação aos pais. Sob sua forma dita positiva, o complexo apresenta-se como na história de Édipo-Rei: desejo da morte do rival que é personagem do mesmo sexo e desejo sexual pela personagem do sexo oposto" 
transgredidos, possibilitando ainda os processos sublimatórios. Kaës (2005b) enfatiza que, quando essas renúncias são possíveis, a sublimação se instala no lugar da repressão severa e cruel e torna possível o nascimento do desejo, do amor e da criação. Como consequência desse contrato, temos a garantia de que ele oferece a cada um a segurança necessária à formação do pré-consciente, ao trabalho do pensamento e à manutenção dos vínculos. Com efeito, Kaës (2005a) compreende o pré-consciente como uma instância intermediária, de passagem, de mediação e de transformação, responsável pelos processos de elaboração, mas também por processos que possibilitam a transformação da pulsão e das angústias em elementos de figuração, de representação e significação capazes de se articular com outros elementos figurativos do pensamento e, assim, produzir sentidos ao vínculo intersubjetivo.

Do contrário, em decorrência, quando falhas nas "garantias metassociais" se revertem em falhas no estabelecimento desse contrato, é possível deduzir, como o autor, que "objetos não transformados, incorporados ou convertidos em atos, fabricam uma máquina

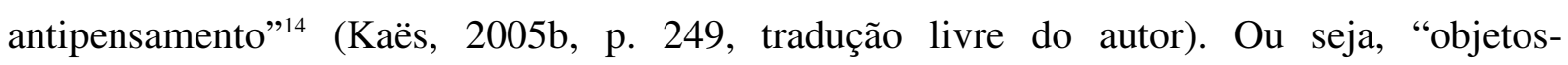
pensamentos" brutos são evacuados de diversas formas (actings ${ }^{15}$, identificação projetiva ${ }^{16}$, violência associada às angústias primitivas e arcaicas etc.) ou poderão ser expressos pelas alucinações, pelas doenças psicossomáticas e por pensamentos ideológicos. Buscando comprovar sua tese, o autor sublinha que são estas as manifestações clínicas do sofrimento psíquico contemporâneo. Em suma, falhas no contrato de renúncia à realização direta aos fins pulsionais têm ligações imediatas com a produção da violência, com falhas no processo de formação do pré-consciente e, por consequência, com dificuldades de formação de sentido nos vínculos intersubjetivos.

Com relação ao contrato narcísico (Aulagnier, 1979), de acordo com Kaës (2005b), é por meio desse contrato que cada recém-nascido vem ao mundo como portador da missão de

(Laplanche, 2004 p. 77). O desfecho deste complexo é a renúncia de suas satisfações eróticas sedutoras e a identificação com o pai (Dolto, 1980). Nas palavras de Freud (1924/1969): "Nesse conflito, triunfa normalmente a primeira dessas forças: o ego da criança volta as costas ao complexo de Édipo. (...) As catexias de objeto são abandonadas e substituídas por identificações. A autoridade do pai ou dos pais é introjetada no ego e aí forma o núcleo do superego, que assume a severidade do pai e perpetua a proibição deste contra o incesto, defendendo assim o ego do retorno da catexia libidinal" (Freud, 1924/1969, p. 196, grifos nossos).

${ }^{14}$ Tradução livre do autor : "Les objets non transformés, incorpores ou convertis en acte, fabriquent une machine anti-pensée" (Kaës, 2005b, p. 249)

${ }^{15}$ Acting Out é um "termo usado em psicanálise para designar ações que apresentam quase sempre, um caráter impulsivo, relativamente em ruptura com os sistemas de motivação habituais do sujeito, relativamente isoláveis no decurso de suas atividades, e que toma muitas vezes uma forma auto ou hetero-agressivas" (Laplanche, 2004, p. 6).

${ }^{16}$ Identificação Projetiva é uma "expressão introduzida por Melanie Klein para designar um mecanismo que se traduz por fantasias em que o sujeito introduz a sua própria pessoa (his self) totalmente ou em parte no interior do objeto para o lesar, para o possuir ou para controlar" (Laplanche, 2004, p. 232). Para os autores, a identificação projetiva surge como uma modalidade de projeção na qual o sujeito tende a projetar aquilo que rejeita em si, uma projeção do que é mau (pulsões destruidoras do sujeito). 
assegurar a continuidade da família, de um modo particular, assegurando assim um lugar nesse grupo e do qual receberá investimento narcísico. A principal função desse contrato, o autor explica, é a de manter a continuidade de investimento de autoconservação em cada sujeito e no conjunto do qual faz parte. Além disso, possibilita ao grupo familiar manter uma ideia de temporalidade, de projeto e de futuro, na medida em que cada membro do conjunto se responsabiliza por manter vivo o passado e o futuro dos valores e crenças particulares, daquilo que dá singularidade àquela formação familiar. Porém, essa dimensão de temporalidade, de permanência no tempo, o autor sublinha, está em desacordo com as condições de existências contemporâneas: cada vez mais o futuro se torna imprevisível e cada vez menos a tradição tem influência sobre o presente e o futuro.

Em uma sociedade pautada na globalização, no pluralismo dos sistemas de pensamento e na diversidade cultural, o sujeito contemporâneo tende a não mais se comprometer em levar adiante a tradição de cada família. Assim, observa o autor, configurase um mal-estar contemporâneo em termos de inseguranças e incertezas, já que o sujeito, sem a pretensão de levar adiante os valores próprios da família, não garante a esta o seu futuro como instituição singular, de sorte que não recebe em troca o apoio narcísico de investimento desse grupo. Disso decorrem ainda instabilidades em torno das formações vinculares, porque, quando cada membro decide sobre seus passos, por meio da assimilação de novos valores e crenças, os membros da família se tornam menos identificados uns com os outros. São as diferenças marcantes entre as gerações. Por fim, como o contrato narcísico está associado à transmissão dos valores e dos ideais estruturantes de cada família, e falhas no estabelecimento desse contrato acarretam igualmente problemas no processo de transmissão da vida psíquica.

Concluindo o pensamento do autor, este declara que falhas ou defeitos nas "garantias metassociais" afetam principalmente organizações psíquicas sensíveis aos efeitos da intersubjetividade, em função de falhas no estabelecimento dos contratos estruturantes do psiquismo. Nesse sentido, ele resume três grandes tipos de consequências: 1. "Falhas ou defeitos nos dispositivos intersubjetivos de paraexcitação (Reizschutz) e de recalque na estruturação dos apoios da vida pulsional" (Kaës, 2011, p. 20), desenvolvendo no lugar de objetos estáveis e confiáveis, “formações clivadas e não subjetivadas, desfavoráveis aos processos de simbolização e sublimação" (p. 20); 2. Falhas "nos processos de formação das identificações e das alianças intersubjetivas estruturantes de base" (p. 20), alianças que são a substância do vínculo intersubjetivo e estão em posição meta em relação às formações psíquicas (pactos de interditos e contrato narcísico); e 3. "Falhas nos processos de transformação e mediação. O que é mais frágil em toda a organização viva são as formações 
intermediárias e os processos articulares" (p. 20). Na vida psíquica, o autor sublinha, tais articulações correspondem tanto ao trabalho de simbolização e de formação da alteridade, quanto às capacidades de amar, de brincar e de sonhar.

Essas formações e esses processos são os mais ameaçados pelas crises que afetam as garantias metapsíquicas. A principal consequência de sua falha está no esboroamento e na exclusão do pré-consciente, no esmagamento da capacidade de pensar pelo desmoronamento das representações verbais. O trabalho do pré-consciente está sempre estreitamente associado à atividade de simbolização e à construção do sentido no vínculo intersubjetivo. (Kaës, 2011, p. 21).

Essas falhas ou desregramentos afetam, sobretudo, a formação dos vínculos intersubjetivos suficientemente estruturados e estáveis, condição necessária para a construção do que Aulagnier (1979) denomina "espaço onde o eu pode advir" (Kaës, 2005b), subjetivamente falando.

Finalizando, concordamos com as proposições do autor e conjecturarmos que, a princípio, são a dificuldade de formação de vínculos intersubjetivos suficientemente estruturados e estáveis; a capacidade de elaboração; de transformação e sustentação da pulsão; e, as dificuldades na constituição de uma alteridade interna subjetivada e externa (Kaës, 2005b) que particularmente nos interessam, para compreendermos a escolha de adultos que optam por não se vincular amorosamente de maneira compromissada, na contemporaneidade.

Parece-nos ainda importante ressaltar que o que Kaës (2005b) afirma não é uma negação ou recusa completa de assunção dos contratos, pactos e alianças, mas falhas, desregramentos ou defeitos nestes processos, porque, de fato, não supomos que essas transformações irão se converter em um retrocesso civilizatório, mas sim em mudanças na organização do psiquismo.

Dessa maneira, não se trata de organizações psíquicas não mais estruturadas em torno do Complexo de Édipo, mas de modificações nessa estruturação. É como afirma Armony (2009): para o autor, a diversidade de escolhas e a permissividade características da contemporaneidade culminaram por deslocar a organização psíquica outrora sob o reinado do superego para a de muitos pequenos egos, que provocam dúvidas, ansiedades, acúmulos e dispersões. Isso faz com que o homem contemporâneo viva "mais num regime de dissociações que de repressões" (p. 81), e esse acesso simultâneo aos pequenos "eus" provoca o sentimento de estar retalhado. Hoje, quando se "faz uma escolha é por tempo limitado, indo de um pequeno eu para outro" (p. 81). Essa situação pode ser angustiante, porque nunca 
haverá tempo para atender às demandas de todos os pequenos eus, até porque em muitos casos estas podem ser conflitantes entre si.

Outro resultado de movimentações na estruturação psíquica é trazido por Tisseron (2008), quando este compreende que a lógica das novas tecnologias e do mundo virtual tem favorecido no funcionamento psíquico o mecanismo de "recusa da realidade". A sociedade que se desenha, frisa o autor, não será mais do recalcamento, mas a da "recusa".

A teoria do autor acima se apoia no entendimento de que, com o desenvolvimento das novas tecnologias, sobretudo de comunicação, surgiram novos modelos de se relacionar que procuram, a todo custo, anular todo o tipo de separação ou afastamento. Além disso, a lógica do mundo virtual, por definição aquilo que tem (somente) o potencial de vir a ser, inaugura uma proposta de relação com o mundo onde cada um decide por si no que acreditar. Todo o sistema que abrange o mundo virtual, no qual tudo pode ser descartado num clique, aliado às imagens fabricadas que as novas tecnologias proporcionam, deixa ao encargo de cada um decidir o que é verdadeiro ou falso.

O mecanismo de defesa apontado por Tisseron (2008), diferentemente do conceito de negação, deve ser compreendido como associado antes de tudo à recusa da castração. Fassin (2006) explica que a diferença entre os mecanismos de defesa "recusa" (Verleugnung) e "negação" (Verneinung) assume a sua importância na distinção entre fatos e suas representações. O primeiro, o da "recusa", consiste numa ação psíquica que rejeita a realidade em razão de sua característica desagradável, insuportável e potencialmente traumatizante. É importante salientar que não fazemos a recusa de uma presença, mas de uma ausência, como no caso da ausência do pênis na mulher, o que leva a consequências mais graves para o processo de simbolização, pelo qual poderíamos representar a falta. O mecanismo da recusa realiza um processo de representação, porém, que não perdura em significado, porque a ausência tende a ser representada e recusada na sequência. Trata-se de um bloqueio, de uma clivagem do ego, a qual pode tomar formas patológicas, como no caso da psicose. No mecanismo de negação, entretanto, o processo psíquico permite a anunciação de maneira negativa de um conteúdo de um desejo inconsciente. De maneira geral, a negação preserva a representação da realidade e sua significação, mas ela separa os elementos mais desagradáveis. Assim, reconhece-se a realidade da qual se deseja reprimir e há um contato com a falta, ainda que estabelecido através da negação. O processo de afastamento do desagradável é menos profundo na negação do que na recusa, porque, nesta última, o desagradável simplesmente não assume nenhum sentido (Fassin, 2006). 
Em todo caso, o que Armony (2009) e Tisseron (2008) constatam está perfeitamente de acordo com o que Kaës (2005ab) demonstrou. Trata-se não mais do reinado do superego, instância psíquica representativa de uma organização social estável e hierárquica, o que leva, em última instância, à falhas nos processos de elaboração, em que podemos tomar a cisão e/ou o mecanismo de recusa como consequências dessas falhas. Quer dizer, assistimos a um afloramento de mecanismos de defesas pobres em capacidades de simbolização, em função de falhas nas "garantias metassociais" e "metapsíquicas", como assinalou Kaës (2005ab).

Assim como Freud (1930/2006) salientou, o mal-estar na civilização resulta de sofrimentos em função das exigências de uma sociedade que irremediavelmente frustra. Conjecturando, antes do fim, entendemos que, se há algo que mudou desde Freud (1930/2006), é justamente a capacidade de lidar com a frustração, porque a capacidade de transformá-la ampara-se em "garantias" falhas (Kaës, 2005). Atualmente, é a capacidade de representar a falta que está em questão. Existe uma relação direta entre a capacidade de fazer junto e a de suportar a frustração de situações decepcionantes, conforme Tisseron (2008), e a criança e o adulto que não são capazes de brincar experimentam dificuldades em lidar com os eventos dolorosos e acabam lidando com essa dor pela via da recusa ou da violência ou, mais frequentemente, pelas duas vias. 
Capítulo III

\section{Da Intersubjetividade à Transmissão Psíquica}

\section{Intersubjetividade}

Desde Psicologia de Grupo e a Análise do Ego, Freud (1921/2006) passou a conceber o sujeito a partir de outro olhar. Deixou de lado a concepção solipsista de um aparelho psíquico individual e começou a considerar a determinação do sujeito com fundamento em um campo intersubjetivo, ao observar a exigência de trabalho psíquico imposta ao psiquismo através do trabalho da cultura (Kaës, 2005b). Freud (1921/2006) inicia essa obra anunciando que a vida psíquica de um indivíduo não deve ser tomada isoladamente, pois sofre influência de um modelo, de um adversário, de um oponente etc., e por isso devemos considerar que a psicologia individual também é psicologia social. Encontramos sob essa base um dos "enunciados fundadores de uma abordagem intersubjetiva do sujeito, ao mesmo tempo em que a hipótese de que um conjunto dos outros forma uma Gruppenpsyche" (Kaës, 2011, p. 27).

O conceito de intersubjetividade, de acordo com autores psicanalíticos contemporâneos, foi construído em meio a problemáticas oriundas do campo da filosofia e da psicologia, desde o momento em que se tornou importante pensar o sujeito levando em conta o reconhecimento do próximo (Jaroslavsky \& Morosini, 2010). Ou seja, como afirmam Coelho Junior e Figueiredo (2004), “com as exigências éticas colocadas pela necessidade de reconhecimento da alteridade como elemento constitutivo das subjetividades singulares" (p. $10)$.

Para Jaroslavsky e Morosini (2010), as fontes iniciais do estudo da intersubjetividade são diversas, como a fenomenologia de Hegel, com a dialética do senhor e do escravo; e a fenomenologia de Husserl (1929/1969), que “desenvolveu argumentações centrais quanto à fundamental importância da experiência intersubjetiva para toda e qualquer forma de conhecimento de si e do outro" (Coelho Junior \& Figueiredo, 2004, p. 10). Além desses, temos os trabalhos de Scheler (1923/1971), Heidegger (1927/1962), Merleau-Ponty (1964) e Lévinas (1974), que deram prosseguimento ao estudo de Husserl (1929/1969), bem como a 
linguística da enunciação, a psicologia da interação e a etnologia. No entanto, como apontam Jaroslavsky e Morosini (2010), a intersubjetividade em todas essas vertentes é tomada apenas do ponto de vista descritivo, ou seja, esses filósofos foram capazes de descrever uma certa categoria de fenômenos, que, de forma geral, torna inegável a importância do outro na constituição do sujeito, mas não foram capazes de explicá-los.

Conforme Jaroslavsky e Morosini (2010), Kaës (2011) foi quem permitiu o entendimento dos mecanismos psíquicos no campo intersubjetivo, como em formações de grupos. Para além de um fenômeno de interação, este autor define intersubjetividade como

a estrutura dinâmica do espaço psíquico entre dois ou mais sujeitos. Esse espaço comum, conjunto, partilhado e diferenciado compreende processos, formações e uma experiência específicos, por meio dos quais cada sujeito se constitui, por um lado que concerne a seu próprio inconsciente. Nesse espaço, sob certas condições, especialmente da libertação das alianças que o mantém submetido aos efeitos do inconsciente, mas também que o estruturam, um processo de subjetivação torna possível tornar-se EU, pensando seu lugar de sujeito no interior de um Nós. (Kaës, 2011, p. 224).

Dessa forma, Jaroslavsky e Morosini (2010) concebem a intersubjetividade como condição para o processo de subjetivação do sujeito. Partem da concepção de Kaës (2011), para quem a intersubjetividade não é meramente descritiva, já que considera todo o trabalho psíquico entre dois ou mais sujeitos e, principalmente, do grupo familiar na construção do sujeito. Por esse processo, o sujeito se torna sujeito da herança, e seu inconsciente é formado e trabalhado pelos vínculos intersubjetivos. Procurando desprender-se das alianças inconscientes do grupo familiar primário, o sujeito se constituirá como sujeito, subjetivandose em meio à intersubjetividade (Kaës, 2011).

Assim, o processo intersubjetivo e o trabalho interno do sujeito abrem caminho para o processo de subjetivação. "Eles o sustentam em sua libertação das identificações alienantes e das alianças inconscientes que o mantêm na sujeição" (Kaës, 2011, p. 223). A subjetivação, por esse meio, é um processo de transformação do sujeito assumido pelo Eu que está sob o efeito das situações dos sujeitos do inconsciente do vínculo. O sujeito do inconsciente referese a um sujeito submetido às formações e aos processos do inconsciente, estando, portanto, sob o efeito de "uma ordem, de uma instância, de uma lei que o constitui em sujeito" (Kaës, 2011, p. 222).

No espaço intersubjetivo, pois, as alianças inconscientes se formam, constituindo sujeições e subjetividade, uma vez que o sujeito é "representado e procura se fazer representar nas relações de objeto, nas imagos, identificações e fantasias inconscientes de um outro e de um conjunto de outros" (Kaës, 2011, p. 225). Esse processo faz emergir uma subjetividade, impondo trabalho psíquico e ligando um aos outros: desse modo, "cada sujeito se liga em 
formações psíquicas desse tipo com os representantes de outros sujeitos, com os objetos que ele abriga em si. Ele os liga entre si” (p. 225). Dessa maneira, Kaës (2011) denomina intersubjetividade "o trabalho psíquico do inconsciente do outro ou de mais-de-um outro na psique do sujeito do inconsciente" (p. 225).

Para Fernandes (2004), Kaës (1997) propõe a construção de uma metapsicologia intersubjetiva composta por uma relação entre o duplo limite constitutivo do espaço psíquico: "entre o Inconsciente e o Pré-Consciente/Consciente e, o limite interpsíquico entre Sujeito (Soi) e o não-Sujeito (non-Soi)" (Fernandes, 2004, § 19). É dessa forma, ainda segundo a autora, que o trabalho psíquico da intersubjetividade é concebido "como o trabalho de um outro ou mais de um outro na psique do Sujeito do Inconsciente" (Fernandes, 2003, p. 50). Tal processo permite sobretudo que o sujeito em sua singularidade adquira graus diversos de “aptidões" para significar e interpretar,

receber, conter ou recusar, ligar e desligar, transformar e (se) representar, de "brincar" com ou destruir os objetos e as representações, as emoções e os pensamentos que pertencem a um outro sujeito, que transitam através de seu próprio aparelho psíquico e que se tornam, por incorporação ou introjeção, partes "encerradas" - "enquistadas", ou integrantes e reutilizáveis. (Fernandes, 2003, p. 51).

Neste capítulo, serão abordados conceitos da psicanálise que auxiliam a pensar o indivíduo enquanto um sujeito em meio a outros, cujos vínculos são constituintes de sua subjetividade e do seu psiquismo, desde antes de seu nascimento. Na sequência, daremos ênfase ao conceito de vínculo e aos aportes teóricos que fundamentam o processo da transmissão psíquica.

\section{O Conceito de Vínculo}

A psicanálise de família, de casal e de grupo levou autores contemporâneos, segundo Puget (2000), a descobertas que superam as teorias concebidas a respeito do funcionamento de um aparelho psíquico individual. Foi possível tomar consciência de que "não existe apenas a realidade forjada pelas fantasias inconscientes e a vida pulsional, mas que há outra, a que se cria a cada encontro entre dois ou mais sujeitos" (p. 73).

A noção de vínculo é tardia na teoria psicanalítica e é distinta da noção de representação e de relação de objeto. Apareceu, segundo Moguillansky (1999), desde a 
necessidade de pensar o sujeito do inconsciente como um sujeito da herança ${ }^{17}$ e da crescente importância de considerar o intersubjetivo na constituição do indivíduo, no seio de suas relações familiares.

A relação de objeto refere-se à relação que o ego tem com um objeto, mais precisamente com um objeto interno (Moguillansky, 1999). A relação do ego ou do self com o objeto interno condiciona, medeia, colore a relação com o objeto externo. A noção de vínculo, por sua vez, esteve presente desde o início na obra freudiana, mas passou a ganhar mais peso e consistência teórica com as obras de Bion (1970), de Berenstein e Puget (1993) e de Kaës (1997). O conceito de vínculo tem como característica básica o fato de ser um fenômeno que aborda a mediação, a construção intersubjetiva entre os sujeitos e, assim, cada ego que constitui a dupla tem importância nessa constituição. Isso significa que aspectos relativos à singularidade do outro têm a potencialidade de atingir a constituição subjetiva do eu. Destacam Trachtenberg et al. (2005b):

Na relação vincular, o desejo circula de forma bidirecional, pois ambos os egos são, simultânea e sucessivamente (pacto, acordo), lugar do desejo e da realização do desejo do outro. Já a relação de objeto, entendida como o registro no mundo interno dos objetos parciais ou totais nos quais o ego investe de forma unidirecional, é intraterritorial da perspectiva do aparelho psíquico, delimitando o espaço intrasubjetivo. (Trachtenberg et al., 2005b, p. 171-2)

Pode-se perceber, por conseguinte, que o vínculo precede a relação de objeto, porque esta corresponde a uma fantasia de interiorização do vínculo que se formou e se desenvolve com um objeto da realidade externa (Jaroslavsky \& Morosini, 2010). Esses autores, assim, consideram que existe uma relação dialética entre vínculo e relação de objeto, já que a relação de objeto é o motor do vínculo, organizando-o e criando-o. Dessa forma, também se evidencia o caráter de transformação que o vínculo impõe ao sujeito, pois o leva a questionar realidades inconscientes específicas que se diferenciam daquela vivenciada com o outro ego.

$\mathrm{O}$ vínculo intersubjetivo deve ser concebido como uma relação de reciprocidade entre dois sujeitos cujos inconscientes se influenciam mutuamente, segundo Eiguer (2008). O termo intersubjetivo ligado ao de vínculo significa, para o autor, que estão reunidos, na verdade, três psiquismos: o do sujeito, o do outro e o da relação entre eles, sem que nenhum deles possua privilégio sobre os demais. Não se trata, por isso, de pensar sobre uma relação que se estabelece entre duas subjetividades, mas entre dois sujeitos do inconsciente. $\mathrm{O}$ sujeito do inconsciente busca no outro uma via para a realização de seus desejos. Na realidade, busca

${ }^{17} \mathrm{O}$ sujeito da herança, segundo Kaës (2001), é aquele dividido, "como o sujeito do inconsciente, entre a necessidade 'de ser um fim para si mesmo' e de ser 'o elo de uma cadeia à qual está sujeito sem a participação da vontade"” (Kaës, 2001, p. 11). 
mais especificamente encontrar o seu desejo encontrando o do outro, afirma. A subjetividade de um dos sujeitos capta o desejo do outro, porém, nem sempre, pois o importante é que o processo intersubjetivo tenha seu lugar, esclarece. Até porque todo vínculo terá algo de dissimétrico, visto que cada sujeito se encontra imerso em expectativas e na dependência do outro, diante da esperança de realização dos próprios desejos por meio do outro, o que perdura até o instante em que o desejo do outro se manifesta (Eiguer, 2008).

Assim, descobrimos que o vínculo impõe o trabalho psíquico da transformação dos sujeitos através de seu próprio processo, que mobiliza o sujeito a conhecer aquele que pensava conhecer. Além disso, as diferentes formas de identificação, mecanismos projetivos cruzados (identificações primária, secundária, narcísica, projetiva etc.) ${ }^{18}$, todas as emissões provenientes do outro sujeito deverão ser tratadas, elaboradas pelo aparelho psíquico do sujeito. De acordo com Eiguer (2008), o funcionamento psíquico é predisposto ao vínculo e se estrutura nessa base.

Eiguer (2008) propõe, portanto, que o "vínculo é a relação de reciprocidade entre dois sujeitos (ou vários) cujos funcionamentos psíquicos estão articulados e se influenciam mutuamente: pensamentos, afetos e atos interagem"19 (p. 34, tradução livre do autor). Contudo, o autor não concorda com Freud (1932/2006), para quem a libido na base do processo de investimento de objeto é masculina. O "feminino" intervém nos vínculos por intermédio da capacidade de recepção do outro, sustenta Eiguer (2008). Antes de reconhecer o que o outro diz, assim que sente o impacto de sua presença, o sujeito se pergunta por que o outro exprime o que exprime, e é surpreendido, às vezes, por um sentimento de estrangeirismo que o toma, de sorte é dessa maneira que procura decifrar, identificar as sensações que o outro lhe desperta. O sujeito procura sentir o que nele é diferente do outro, o que o conduz a se reconhecer e a se descobrir, talvez, diferente do que ele pensava ser inicialmente.

\footnotetext{
${ }^{18}$ A identificação "é um processo psicológico pelo qual um sujeito assimila um aspecto, uma propriedade, um atributo do outro e se transforma, total ou parcialmente, segundo o modelo desse outro" (Laplanche, 2004, p. 226). A identificação primária opõe-se à identificação secundária, "não apenas na medida em que ela é a primeira cronologicamente, mas também na medida em que não se teria estabelecido consecutivamente à uma relação de objeto" (Laplanche, 2004, p. 232) e, portanto, a identificação primária seria "a forma mais originária do laço afetivo com um objeto" (p. 232). A identificação projetiva é uma "expressão introduzida por Melanie Klein para designar um mecanismo que se traduz por fantasias em que o sujeito introduz a sua própria pessoa (his self) totalmente ou em parte no interior do objeto para o lesar, para o possuir ou para controlar" (Laplanche, 2004, p. 232). Na identificação narcísica, há um ataque à separação e à diferenciação, porque o ego não pode se confrontar com o diferente de si e, por conta disso, quando o outro o desaponta, tende a voltar a catexia objetal para si (Freud, 1917/2006).

${ }_{19}$ Tradução livre do autor: "le lien est la relation de réciprocité entre deux sujets (ou plusieus) dont le fonctionnements psychiques sont articulés et s'influencent mutuellement : pensés, affects et actes interagissent" (p. 34).
} 
Ainda nesse processo, o sujeito procura associar o outro a algum de seus vínculos inconscientes e termina por tomar uma posição em face dele, o que Eiguer (2008) chama de vínculo objetal. Também será inevitável, nesse processo, a comparação entre seus pensamentos, suas sensações com as do outro, e o sujeito então começará a se ver de outra maneira. Dessa forma, inicia-se um processo constante, no qual o sujeito não será mais o mesmo, porque sua identidade será marcada pela percepção da singularidade do outro. "Ele foi penetrado pelo outro, se identificou de uma certa maneira com ele e foi fertilizado por ele" 20 (Eiguer, 2008, p. 37, tradução livre do autor).

No começo de todo esse processo, apenas o similar e o parecido são predominantes. Entramos num vínculo pela porta da ilusão, ressalta o autor, e somente mais tarde é que o processo de desilusão tende a intervir e a sublinhar em que o outro é diferente. Nesse contexto, a presença do ódio e das brigas em um relacionamento é compreendida como natural, porque é somente num segundo momento que o outro poderá realmente ser reconhecido.

Em essência, recuperando todo o exposto, o autor propõe pensar a "terceira instância do vínculo" como composta por quatro níveis: 1 . O nível mais profundo, arcaico, refere-se a uma certa indiferenciação entre as identidades dos dois sujeitos, movimento em que o narcisismo tem um papel decisivo. 2. O nível onírico apreende a busca pela realização dos desejos inconscientes, a esperança pela realização dos desejos oriundos do ideal de ego, suas ambições e projetos. 3. O nível mítico supõe a produção de fantasias coletivas que sustentam o trabalho do pré-consciente e que são sustentadas por ele. 4. E o nível legislativo é relativo às leis específicas e particulares dos vínculos que abrangem os interditos e as pré-inscrições condizentes aos gestos e atos do outro. As leis concernentes à diferença de sexo e de geração constituem esse conjunto.

Além dos quatro níveis que formam a estrutura do vínculo, Eiguer (2008) ainda o concebe fundamentado sob quatro características, que denomina "os quatro R" do vínculo: reciprocidade, respeito, reconhecimento e responsabilidade.

A reciprocidade e o respeito são os conceitos mais simples. A reciprocidade resulta da maneira como os sujeitos do vínculo interagem e da possibilidade de um investimento intersubjetivo criativo. O respeito ao outro supõe a ausência de maus julgamentos e resulta de um longo trabalho de aproximação, no qual o outro lhe parece próximo e ao mesmo tempo

\footnotetext{
${ }^{20}$ Tradução livre do autor: "Il a été pénétré par l'autre, s'est identifié d'une certain façon à lui et a été fertilisé par lui" (Eiguer, 2008, p. 37).
} 
diferente. $\mathrm{O}$ respeito ainda advém do amor e do sentimento de ter construído em conjunto um universo compartilhado, supondo-se a capacidade de aceitar a singularidade do outro.

O reconhecimento é um processo mais complexo. Eiguer (2008) primeiramente apoiase em Benjamin (1988/1992), para quem o vínculo se encontra na tentativa de equilibrar a afirmação de si e o reconhecimento do outro: para conseguir se afirmar, é preciso o reconhecimento do outro. A autora alude à existência de um paradoxo nesse processo, porque o ego ao mesmo tempo em que possui a necessidade do reconhecimento do outro e, portanto, de concebê-lo como separado de si, procura se fundir com este outro, a fim de se tornar um único e absoluto, num universo onde não haja conflitos. $\mathrm{O}$ ego precisa do reconhecimento do outro, de que seus atos sejam significantes para o outro, para que se tornem significantes para si mesmo. Contudo, nesse movimento, o outro tende a resistir, porque cada vez que é afetado pela subjetividade alheia se modifica e para preservar sua identidade ele resiste (Benjamin, 1988/1992). Assim, nasce um mal-estar, assinala Hegel (1807/1998), de acordo com Eiguer (2008), porque, nesse processo, enquanto o outro resiste e parece incontornável, o sujeito pode tentar dominá-lo. O sujeito poderá se servir do outro, dominá-lo, porque precisa da preciosa certeza que advém do outro de ser "ele-mesmo", para poder existir, de onde, segundo Benjamin (1988/1992), decorre a submissão habitualmente imposta às mulheres. Por isso, o processo que em psicanálise denominamos "diferenciação" 21 supõe o trabalho do reconhecimento do outro, conforme Benjamin (1988/1992), porém, a natureza desse movimento é contraditória e paradoxal. Ainda que Eiguer (2008) compreenda a dificuldade de tal tarefa, entende que, se um vínculo não é capaz de suportar esse movimento paradoxal, não se sustenta. E esse processo é interminável, pois só podemos reconhecer o outro à medida que não o conhecemos verdadeiramente, e nem a nós mesmos.

Por conseguinte, o espírito é antes de uma busca, de uma tentativa, de um desejo de reconhecer e ser reconhecido. Restará sempre uma sombra em cada membro do vínculo, mesmo que isso seja angustiante, porque o processo de conhecimento pleno do outro não é possível. Reconhecemos o outro justamente porque nós o desconhecemos: isso significa aceitar a existência de uma parte obscura de sua singularidade (Eiguer, 2008).

\footnotetext{
${ }^{21}$ Enfatiza Zimerman (2004): "Segundo M. Mahler (1975), quando o bebê sai da fase 'simbiótica', ele ingressa na etapa da 'diferenciação', composta de duas subetapas, respectivamente denominadas, pela autora, 'separação' (em relação à mãe) e 'individuação' (coincide com o início da marcha). Se as mesmas forem superadas, satisfatoriamente, possibilitarão o 'nascimento psicológico' da criança, a um mesmo tempo em que se abrirão as portas para as demais etapas até a obtenção de uma 'constância objetal', com a construção de uma confiança básica" (p. 253). O autor ainda salienta que o estado de indiferenciação "é o eixo principal em torno do qual giram as demais características da posição narcisista na pessoa adulta, muito particularmente aquelas que dizem respeito à falha relativa ao reconhecimento de um inevitável estado de incompletude e à aceitação das óbvias diferenças que separam as singularidades de cada indivíduo com quem o sujeito narcisista convive" (Zimerman, 2004, p. 254).
} 
Dessa forma, reconhecer não significa conhecer melhor, mas conhecer um pouco menos aquele que supúnhamos conhecer no início. À medida que nossas fantasias vão sendo colocadas em questão, renunciamos a uma parte da soma de tudo saber sobre o outro. Isso acarreta igualmente admitir que o outro pode nos esquecer e mesmo falhar em suas promessas (Eiguer, 2008). A possibilidade de reconhecimento do outro não pode ser conquistada sem a possibilidade de aceitar a diferença, a própria falta e o reconhecimento do que há de positivo no outro. Implica saber lidar com a angústia de castração ${ }^{22}$, assinala o autor.

Eiguer (2008) explica que o sujeito tende a apreciar no outro qualidades que ele mesmo não tem, e se o outro o reconhece em suas qualidades, isso poderá reconfortá-lo e suscitar a gratidão. Por fim, o que conta na formação de um vínculo não é tanto o que um aprecia no outro, mas o fato de admitir as diferenças e comunicá-las. Os dois, admitindo suas faltas e qualidades alheias, constituem um ciclo de reconhecimento.

Entretanto, nem sempre esse processo é simples, porque, como ressaltam Santona e Zavattini (2005), nascido de objetos internos, o clima emocional de um casal pode ser perpassado por recíprocas projeções tão intensas quanto forem as dificuldades dos sujeitos em aceitar a separação e a diferença no vínculo. Esses autores sustentam que todos temos uma tendência a encenar papéis no vínculo, convidando o outro a participar de uma dinâmica que retrata dramas interiores inconscientes e conscientes. Num vínculo amoroso, seus membros são implicados num processo de alimentação e de ressonância das fantasias internas que se comunicam via inconsciente, de sorte que os autores frisam ainda que saber separar realidade interna de externa nem sempre é um processo viável ou fácil. Um casal pode justamente se unir por meio da "assinatura" de um contrato inconsciente, em que os papéis que desempenham fazem retomar dramas vividos através de projeções maciças cruzadas. Tais aspectos podem interferir na capacidade de reconhecimento e diferenciação do outro, essenciais para que o vínculo seja vivido de forma prazerosa e saudável, como salienta Eiguer (2008).

Além do reconhecimento que advém do vínculo, Eiguer (2008) aponta a importância do reconhecimento social, do grupo e dos pais para a construção da identidade e da estima de si mesmo. Estas dependem da apreciação do exterior para se formar, a qual, se for negativa, altera a imagem de si e potencializa o risco de uma autodepreciação. Assim, no processo de reconhecimento do outro, está em jogo a identidade de cada um: os olhares que recebemos

\footnotetext{
${ }^{22} \mathrm{O}$ complexo de castração, embora se refira à fantasia de castração do pênis, pode situar a angústia de castração a uma série de experiências traumatizantes "em que intervém igualmente um elemento de perda, de separação de um objeto" (Laplanche, 2004, p. 74).
} 
têm o potencial de nos valorizar e contribuir para a consolidação de nossa identidade. Portanto, o narcisismo assume um papel fundamental nesse processo. Eiguer (2008) retoma a ideia de Freud (1914/2006) de que os pais possuem um papel essencial na construção da estima de si e para a vida de seus filhos, por viabilizarem uma promessa de futuro quando projetam neles seus sonhos não realizados, imaginando e desejando que possam realizá-los.

Apesar da atenção considerável que dá ao conceito de reconhecimento, o autor pensa a sua importância somente em relação com os outros conceitos que caracterizam o vínculo: a responsabilidade, o respeito e a reciprocidade. Dentre eles, falta-nos a explicação do conceito de responsabilidade.

Com relação a esse conceito, Eiguer (2008) constata que o trabalho de Lévinas (1974) é muito precioso para pensá-lo, mas não apenas: para o autor, o sentimento de culpa tomado pela teoria freudiana como principal organizador do superego deveria ser revisado à luz do conceito de responsabilidade. Sentir-se culpado é diferente de se sentir responsável, afirma Eiguer (2008): a culpa sugere a ocorrência de um erro e a responsabilidade aborda também os bens e as ações construtivas. Num vínculo compromissado, a responsabilidade conduz a perspectivas mais vastas que a culpabilidade, já que, sob os efeitos da primeira, desejamos nos aproximar do outro, cuidar dele e ajudá-lo, se necessário, enquanto o sentimento de culpa tende a ser um paralisante.

Aquilo que o sujeito recebe de seus pais lhe permite desenvolver um sentimento de responsabilidade com relação aos outros, aos seus futuros filhos e em relação a todo o outro (Eiguer, 2008). O reconhecimento pela devoção dos pais, pelo cuidado, pela educação torna a criança devota dos pais e responsável pelo futuro deles. Nasce então uma dimensão ética, que não é de obrigação, mas de responsabilidade. Entretanto, Eiguer (2008) destaca que, se os pais oferecem tudo isso aos filhos, fazendo-os sentir que devem se sacrificar por eles, a dívida será demasiadamente pesada e os impedirá de desenvolver um sentimento de responsabilidade ponderado e de traduzir em emoções seus atos.

Nesse sentido, o autor observa que, apesar de a culpa realmente ter um lugar importante na formação do superego, por meio da teoria dos vínculos, é possível perceber que o papel do superego no contrato com o outro assume também as vertentes da ética, da responsabilidade e da solidariedade pelo próximo.

A noção de responsabilidade, para o filósofo Lévinas (1974), é antes de tudo ética (Eiguer, 2008). Trata-se de uma preocupação pelo próximo que surge diante de sua existência. O sujeito reclama seu direito de existir e o direito ao respeito de sua diferença. A ideia de uma "ética que precede" encontra sua confirmação em desenvolvimentos teóricos psicanalíticos, 
para Eiguer (2008): a ordem simbólica, a fantasia originária ${ }^{23}$ e o transgeracional são os ativadores psíquicos do sentimento ético. Ou seja, tudo o que precedeu o nascimento do sujeito o convida a aceitar a Lei - bem como as regras da parentalidade, seus vínculos e funções familiares -, além dos lugares de cada um dentro da lógica geracional e as leis da linguagem.

\subsection{Particularidades do vínculo amoroso}

Tratando da complexidade do conceito de vínculo intersubjetivo, Eiguer (2008) aborda ainda a importância da influência da opinião dos outros, na constituição do psiquismo. Esse processo é perceptível em todo tipo de vínculo, mas assume um caráter particular no caso do vínculo amoroso: para o autor, se uma pessoa amada exprime uma opinião, ela é ouvida com bastante respeito, porque, por estar muito dependente do que a pessoa querida pensa, o apaixonado a idealiza e lhe atribui um julgamento próximo ao da perfeição. O apaixonado fica quase à mercê, está frágil e pronto a se recolocar em questão sem a menor objeção. Qualquer detalhe ínfimo pode ser interpretado como rejeição, o que suscita angústias desmesuradas. O ego do apaixonado não lhe pertence por inteiro: a outra metade se encontra junto da pessoa amada (Eiguer, 2008).

Eiguer (2008) explica que a opinião alheia implica uma crença sobre si vinda de outra pessoa que, junto ao superego, exerce forte influência sobre o sujeito. No entanto, essas opiniões obterão maior impacto, se as crenças sobre si mesmo forem frágeis. E o autor complementa: quais são os indivíduos indiferentes ou impenetráveis às opiniões alheias? "Nós os encontramos entre os pacientes narcísicos, o paranoico, o psicótico. Eles construíram uma tal couraça de modo que se tornam insensíveis, ignoram o outro, o que ele diz, pensa ou aprova, ainda que se mostrem susceptíveis" ${ }^{24}$ (Eiguer, 2008, p. 19, tradução livre do autor). Nesses casos, as opiniões são interpretadas; e, quando as opiniões não são levadas em conta, ou superficialmente levadas, o vínculo que se estabelece não tem consistência e pertence ao âmbito da patologia, porque levar o outro em consideração testemunha nossa necessidade de relacionamento que tem por pano de fundo a constatação de que não somos completos ou

\footnotetext{
${ }^{23}$ Fantasia originária são "estruturas fanstasísticas típicas (vida intra-uterina, cena originária, castração, sedução) que a psicanálise descobre como organizando a vida fantasística sejam quais forem as experiências pessoais dos sujeitos; a universalidade destas fantasias, explica-se, segundo Freud, pelo fato de constituírem um patrimônio transmitido filogeneticamente" (Laplanche, 2004, p. 174).

${ }^{24}$ Tradução livre do autor "Nous les trouvons parmi les patients nacissiques, le paranoïaque, le psichotique. Ils se sont construit une telle cuirasse qu'ils en demeurent insensibles, ignorant l'autre, ce qu'il dit, pense ou éprouve, même s'ils se montrent sucetibles" (Eiguer, 2008, p. 19).
} 
sabedores plenos. A aceitação da falta é o inverso do mecanismo de recusa, trabalhado no capítulo anterior, implicando em capacidade de elaboração. Assim, as opiniões dos outros servem para nos ligarmos a eles e mesmo para criar um diálogo em nosso interior, já que aquele que recebe uma opinião a escutará fazer ressonância em si, da qual poderá se apropriar, ou a ela se adaptar e transformá-la, segundo sua maneira e perspectivas. Destacamos, portanto, que o autor coloca em evidência a necessidade da presença de mecanismos de elaboração constantes, para podermos estar num vínculo amoroso com o outro que não seja superficial.

De maneira geral, todos os conceitos que envolvem o entendimento de como se forma e se mantém um vínculo serão extremamente importantes para a compreensão posterior do porquê de nossos participantes não desejarem constituir um vínculo amoroso compromissado. Nesse contexto, parece significativo também levarmos em consideração os aportes teóricos desenvolvidos por Eiguer (2010) com relação a um tipo de vínculo amoroso que não se aprofunda: aquele no qual um dos parceiros é favorável à "libertinagem" 25 .

A libertinagem, segundo Eiguer (2008), é na realidade um estilo de vida em que o sujeito procura desfrutar do vínculo sem nele se aprofundar, evitando suas implicações. Concebe o libertino como alguém que possui uma forma particular de ver o mundo, de compreendê-lo, para quem a necessidade de desfrutar da vida está acima de todas as outras. $\mathrm{O}$ gosto pela liberdade, a ética da felicidade e uma busca seletiva e constante pelos prazeres são as bases de sua filosofia. Eiguer (2010) o entende como alguém capaz de compor uma singularidade criativa.

O libertino não crê nas vinculações, porque, para ele, todo vínculo tende ao seu término em função da diminuição da intensidade do encontro, da magia do começo e da emoção da conquista, os quais busca incessantemente. A intimidade psicológica do outro não lhe interessa e a constância o entedia. No entanto, apesar de seus princípios basicamente se resumirem a "degustar" de todas as delícias da sensualidade, o autor ressalta que o libertino tem suas éticas particulares e, por isso, não se trata de alguém desprovido de moralidade, um perverso. O libertino busca por experiências eróticas e o perverso submeter sua vítima aos seus desejos, independentemente da forma e das consequências.

A liberdade é algo de essencial importância para o libertino, e o autor reconhece que podemos encontrar cada vez mais esse estilo de vida presente em nossa sociedade, em função

\footnotetext{
${ }^{25}$ Libertino, de acordo com o dicionário Priberam da Língua Portuguesa é "quem revela um comportamento moralmente desregrado, centrado nos prazeres sexuais". Recuperado em 21 de fevereiro de 2012, de http://www.priberam.pt/dlpo/default.aspx?pal=libertino.
} 
de esta ter-se tornado libertária e partidária de todo tipo de busca pelo prazer, pela qualidade de vida, pelo aproveitamento do tempo livre, do lazer, apelando aos sentidos e às gratificações de todas as maneiras. Como visto no capítulo anterior, a sociedade atual está mais aberta para as novas modalidades de vida e suas diferenças, o que reforça e sustenta a possibilidade que sempre existiu de se ter um estilo de vida libertino.

Todos os libertinos amam a independência, o prazer, os excessos e os privilégios de atingir a felicidade. Em geral, parecem procurar esquecer o passado e jamais pensar no futuro, eles vivem no tempo presente. Para um libertino, a responsabilidade pelo outro, que todo vínculo suscita, não encontra nele o seu lugar. Ele não se preocupa com o outro, porque não se deixa embarcar pelo vínculo. O libertino sabe que todo vínculo tende a tornar o sujeito prisioneiro, por isso, logo o rompe, mas também há por trás desse descompromisso um fato singular: ele sente que não deve nada a ninguém (Eiguer, 2008).

Assim, nesse tipo de vínculo proposto por um libertino, o sentimento da responsabilidade pelo outro assume uma característica pouco significativa, bem como o da reciprocidade de projetos que envolvam um futuro em conjunto. Pensando sobre as razões, os motivos inconscientes para se estar em família, Eiguer (2011) afirma que não são os desejos individuais que assumem uma influência sobre o grupo familiar, mas a reciprocidade que se estabelece entre estes. O sentido da família aparece desde a formação do vínculo amoroso, quando há ressonância entre os ideais do casal, o qual encontra a possibilidade de construir seus projetos em conjunto. Se, de alguma forma, ao longo da construção do vínculo, essa expectativa diminui, o vínculo também pode perder o sentido de ser. Fantasias, afetos, representações comuns e compartilhadas vinculam um ao outro e a reciprocidade entre estes sustenta a manutenção do vínculo.

O vínculo intersubjetivo tem implicações significativas não apenas para a construção da vida de um sujeito, mas também para sua psique. Kaës (2011) assinala que, no processo intersubjetivo do vínculo, o inconsciente do sujeito é moldado, sofrendo influências do grupo familiar que o precede. A psique do sujeito singular se forma, se transforma ou se aliena por meio das diversas modalidades de vínculos intersubjetivos que o precedem, que ele estabelece e que finalmente o constitui como sujeito do inconsciente. Para entendermos essas influências, entraremos no campo dos vínculos intersubjetivos familiares. 


\section{O trabalho da Transmissão Psíquica}

\subsection{O Sujeito do Grupo}

Quando Freud (1921/2006), em sua obra Psicologia de Grupo e a Análise do Ego, destaca a presença da intersubjetividade na constituição psíquica do sujeito, foi também o conceito de transmissão psíquica que passou a ser incorporado à psicanálise, para Kaës (2001). Nesse trabalho, é possível assegurar, segundo esse autor, “que Freud inventa uma genealogia da psique, de suas instâncias e de suas ramificações interpsíquicas" (Kaës, 2001, p. $10)$.

Os pontos nodais da questão da transmissão estão no cerne das interrogações de Freud, observa Kaës (2001), inaugurando a existência de um sujeito da herança, que está dividido, “como o sujeito do inconsciente, entre a necessidade 'de ser um fim para si mesmo' e de ser 'o elo de uma cadeia à qual está sujeito sem a participação da vontade'” (Kaës, 2001, p. 11). O grupo precede o sujeito do grupo e, dessa maneira, o sujeito deve servi-lo, mas por isso pode igualmente esperar tirar benefícios.

No processo de transmissão psíquica entre as gerações, a identificação é o principal mecanismo envolvido (Kaës, 2001). Nesse processo, transmite-se também "aquilo que ampara e assegura as continuidades narcísicas, a manutenção dos vínculos intersubjetivos, a conservação e complexidade das formas e da vida: ideais, mecanismos de defesa, identificações, certezas, dúvidas" [itálicos nossos] (Kaës, 2001, p. 9). Esse tipo de transmissão leva o nome de transmissão psíquica geracional e envolve um trabalho de ligações e transformações entre as gerações. Salienta Granjon (2001):

Tal trabalho permite que o indivíduo se vincule a um grupo, esse grupo a outro, num encadeamento de gerações, é o que dá a noção de "pertencimento" e o que permite a construção da própria subjetividade, dentro de um processo de transformação, de criação, do material que é transmitido. É por esse processo que o indivíduo também se torna, por um lado, autor e por outro proprietário de sua herança. Em última instância, é algo que representa e permeia a história pessoal, familiar e da própria civilização. (p. 24).

Pesquisas centradas em compreender a transmissão psíquica entre as gerações (Haesler, 1992; Levine, 1982; Puget, Kaës et al., 1989; Schacht, 1977; Stern, 1986) sugerem uma urgência ou uma espécie de impulso para transmitir, sob o efeito de um imperativo psíquico incoercível (Kaës, 2001). Essa necessidade "é o resultado de exigências pulsionais inconscientes, nas quais prevalecem ora coerções narcísicas de conservação e de continuidade 
da vida psíquica, ora as do Ideal do Ego e do Superego, mais precisamente a transmissão dos interditos fundamentais" (Kaës, 2001, p. 16).

A transmissão da continuidade evolutiva de uma geração a outra permite que cada uma não parta do "zero" (Granjon, 2001). Essa autora alude ainda à existência de uma urgência imperiosa nesse trabalho, pois uma geração não pode existir sem aquela que a precede, e a vida deve ser transmitida. Desse modo, o projeto do grupo familiar é

transmitir a herança psíquica, adquirida e fundadora de cada um e perpetuar-se dando vida para além dos mortos. (...) Neste contexto, o lugar que cada um ocupa no grupo se relaciona ao lugar na cadeia de gerações, que se relaciona com aqueles que não mais existem e que ele deve gerir, adquirir e transmitir. (Granjon, 2001, p. 20).

No entanto, segundo propõem Passos (2007), Magalhães e Féres-Carneiro (2004), como pensar a formação dos vínculos intersubjetivos e o processo de transmissão geracional, em uma cultura que privilegia individualidades? Para Kaës (2001), na modernidade, encontramos tanto processos de "crise de transmissão", de seus objetos ou de seus processos, quanto a crise do próprio conceito de transmissão:

É sempre num momento crítico da história que emergem e insistem a questão da transmissão e a necessidade de formular uma representação dela no momento em que se instaura, entre as gerações, a incerteza sobre os vínculos, os valores, os saberes a transmitir, sobre os destinatários da herança: a quem transmitir? [itálicos nossos] (Kaës, 2001, p. 25).

Diante desse panorama, Passos (2007) afirma que seria necessário rever o desafio a que estamos submetidos desde os primórdios de nossa existência: "encontrar co-autores com quem possamos escrever a nossa história, ao mesmo tempo em que somos instados a transformá-los ao longo da vida, como condição para a subjetivação" (p. 122). Conforme aponta a autora, na conjuntura atual,

a presença desse outro tem se tornado cada vez mais opaca e nebulosa e, dessa forma, tornase difícil criar e recriar os laços, como é esperado no amadurecimento e no processo de humanização. A dinâmica implícita à formação de laços é processada por meio de deslocamentos e condensações dos afetos. Ela pressupõe uma rede complexa, formada pelo cruzamento entre as demandas de cada sujeito e as metamorfoses sociais. Assim, é preciso refletir sobre as transformações que vêm ocorrendo na sociedade contemporânea, organizadas a partir de rupturas e descontinuidades de variadas intensidades, levando-se em conta, evidentemente, o espaço macro e micro social onde se insere. [itálicos nossos] (Passos, 2007, pp. 122). 


\subsection{O processo de Transmissão da Vida Psíquica}

De acordo com Kaës (2009), as práticas da transmissão nasceram com a humanidade e fazem a humanidade. Dentre elas, estão as transmissões de saberes, de técnicas, de mitos, de crenças, mas aquelas que nos interessam mais particularmente, ele sublinha, são as de conteúdo e processos psíquicos.

Esse autor compreende o "singular" como o espaço psíquico individualizado que contém a marca específica da estrutura, da história e da subjetividade singular: "sua organização pulsional, suas fantasias secundárias, seus mecanismos de defesa e seus conteúdos recalcados e clivados, suas identificações, suas relações de objeto, em suma, o que singulariza o desejo do inconsciente" (Kaës, 2011, p. 54). Entretanto, uma parte do que é singular sempre se origina naquilo que o sujeito herdou, adquiriu e transformou, ou no que permaneceu com ele sem transformação. As alianças inconscientes proporcionam o processo de subjetivação, pois, ao procurar-se diferenciar dessas influências, o sujeito irá transformálas, de forma criativa, em algo que lhe pertença realmente. "Aquilo que herdaste de teus pais conquista-o para fazê-lo teu" (Goethe citado por Freud, 1913/2006, p. 160).

$\mathrm{O}$ que se transmite psiquicamente "são essencialmente configurações de objetos psíquicos, isto é, objetos munidos de seus vínculos com aqueles que precedem cada sujeito" (Kaës, 2005a, p. 128). Isso faz da pré-história do sujeito não somente aquilo que o sustenta e garante pelo positivo, "as continuidades narcísicas e objetais, a manutenção dos vínculos intersubjetivos, as formas e os processos de conservação e complexidade da vida" (p. 128), mas também pelo negativo: aquilo que não pôde ser retido, contido, que não é lembrado, o que "não encontra inscrição na psique dos pais e vem depositar-se ou enquistar-se na psique da criança: a falta, a doença, o crime, os objetos desaparecidos sem traço nem memória; para os quais um trabalho de luto não pôde ser realizado" (p. 128). Nesse caso, o autor considera que o processo de projetar no outro, ou depositar nele, o impensado, as falhas, poderia ser compreendido como o aparelho de "interpretar-significar" de Freud que falhou em várias gerações; ou seja, o pré-consciente.

Esquematicamente, Kaës (2005a) destaca duas modalidades da transmissão psíquica. Na primeira, transmissão sem transformação, também denominada transgeracional (Granjon, 2001), existe uma passagem direta de formações psíquicas de um sujeito para outro, sem operações de transformação. Nesta, o objeto de pesquisa não é somente a continuidade da vida psíquica, mas as "rupturas, as falhas, os hiatos não pensados e impensáveis, o 
nivelamento dos objetos do pensamento, os efeitos da pulsão de morte" (Kaës, 2005a, p. 129). E o autor prossegue:

As características desse tipo de transmissão são de duas espécies: o enquistamento, no inconsciente de um sujeito, de uma parte das formações inconsciente de um outro, que vem, então, assombrá-lo como um fantasma; a hipoteca de um mandato imperativo que o ancestral faria pesar sobre sua descendência. (Kaës, 2005a, p. 134).

$\mathrm{Na}$ segunda modalidade, transmissão com transformação, também conhecida por intergeracional (Granjon, 2001), a realidade psíquica pôde ser trabalhada pela fantasia. Para Trachtenberg (2005a), nesse tipo de transmissão, está em jogo um trabalho psíquico de elaboração que diz respeito ao grupo e ao sujeito do grupo, "favorecendo transformações e conduzindo a uma diferenciação, a uma evolução entre o que é transmitido e o que é herdado" (p. 121).

As duas modalidades de transmissão diferenciam-se essencialmente pelo fato de poderem ou não ser transformadas, quando, no processo de transmissão, acontece ou não o processo simbólico e da introjeção. De um modo geral, "a patologia da transmissão psíquica qualifica-se pelos distúrbios do pré-consciente ou pelos defeitos de constituição do préconsciente, isto é, pelos distúrbios do aparelho de "significar/interpretar"” [itálicos nossos] (Kaës, 2005a, p. 136).

Robion (2003) concebe dois modos de transmissão da vida psíquica, com seus respectivos modos de funcionamento: a transmissão pré-consciente e a transmissão inconsciente. Como Kaës (2001), ele considera que a via real dos mecanismos de transmissão psíquica é a via da identificação, mas acrescenta outra via de grande importância: a via do contrato.

Nesse sentido, para Robion (2003) a transmissão psíquica pré-consciente aborda os "contratos simbióticos", "narcísicos" e "objetal". O "contrato simbiótico" traduz-se numa relação complementar, simbiótica, entre a criança e sua mãe, necessária na primeira infância, em que a criança sente a necessidade de satisfazer os desejos da mãe para conservá-la. Esse tipo de transmissão ocorre através do mecanismo de identificação, visto que a criança será impregnada por uma identidade desejada pela mãe. O "contrato narcísico" acontece por meio do processo de identificação secundária, em que a criança e o conjunto social, por intermediação do pai, estabelecem um pacto de obrigações mútuas em que "se diz" à criança: “assuma esta identidade e então fará parte dos nossos" autor). "O ato identificatório secundário é um ato de inclusão; e o contrato narcísico, um

\footnotetext{
${ }^{26}$ Tradução livre do autor: "Prends cette identité et tu feras partie des nôtres” (Robion, 2003, p. 7).
} 
processo no qual um sujeito produz um esforço de inclusão, e um outro confirma este esforço" 27 (Robion, 2003, p. 7, tradução livre do autor). Finalmente, no "contrato objetal" entra em cena uma exigência de reciprocidade. Essa exigência provém da angústia do esvaziamento psíquico, pois amar um outro implica o risco de sacrificar a afirmação de si mesmo.

Dentro do campo da transmissão psíquica inconsciente, temos, primeiramente, o "contrato simbiótico denegativo" (Robion, 2003). Esse tipo de contrato difere do contrato simbiótico simples, porque, no "contrato simbiótico denegativo", a identidade é absorvida em função de uma dificuldade de recalcamento de certos conteúdos pulsionais do transmissor. Nesse contrato, particularmente uma falha de recalcamento de um sujeito necessita de um outro psiquismo para que o recalcamento se realize no primeiro.

Uma criança que se identifica com o desejo inconsciente parental serve de prótese psíquica ao psiquismo parental com falhas. No contrato simbólico denegativo intervém uma identificação projetiva e uma identificação objetal ${ }^{28}$. (Robion, 2003, p. 9, tradução livre do autor).

Outro tipo de transmissão psíquica inconsciente se dá, segundo o autor, pela via do mecanismo de "identificação projetiva". Através deste, um sujeito atribui a um outro o que ele não pode suportar nele mesmo. Essa identificação escapa à consciência, porque é mascarada pelo sentimento consciente de rejeição e de antipatia em relação ao que o outro portaria de insuportável. Já a "identificação projetiva simbiótica", outra modalidade de transmissão, ocorre quando a "identificação projetiva" por si só não é suficiente, e aquilo que foi projetado deve se inscrever realmente no comportamento do outro, por intermédio da anexação do psiquismo desse outro, como, por exemplo, na formação de um sintoma na criança por necessidades de projeção parental.

De forma geral, a transmissão psíquica inconsciente, para Robion (2003), aborda o mecanismo da "deposição". "Tudo se passa como se o elemento autônomo depositado esperasse tranquilamente o momento de sua transformação" ${ }^{29}$ (Robion, 2003, p. 12, tradução livre do autor). Os elementos brutos passam de uma geração à outra, e caberá à próxima geração a transformação desse material impensado pela geração precedente.

\footnotetext{
${ }^{27}$ Tradução livre do autor: "L'acte identificatoire secondaire est un acte d'inclusion ; et le contrat narcissique, un processus dans lequel un sujet produit un effort d'inclusion, et un autre confirme cet effort" (Robion, 2003, p. 7).

${ }^{28}$ Tradução livre do autor: "Un enfant qui s'identifie au désir inconscient parental sert de prothèse psychique au psychisme parental défaillant. Dans le contrat symbiotique dénégatif interviennent une identification projective et une identification objectale" (Robion, 2003, p. 9).

${ }^{29}$ Tradução livre do autor: "Tout se passe comme si l'élément autonome déposé attendait tranquillement le moment de sa transformation" (Robion, 2003, p. 12).
} 
Finalizando, a base para o processo da transmissão psíquica entre as gerações está no mecanismo de identificação, conforme visto, mas não apenas. Kaës (2005a) destaca a importância das alianças inconscientes (pactos, contratos e acordos), que servem para unir uns aos outros em um grupo, em um casal, em uma família ou em um conjunto institucional, referindo-se a elas como o "cimento" da matéria psíquica.

\subsection{Os Mitos Intergeracionais da Família}

Dentre aquilo que se transmite de geração em geração também estão os mitos familiares. Estes aparecem sobre a forma de uma narrativa que acarreta uma crença compartilhada pela família (Eiguer, 2009). Essa crença, advinda de uma interpretação, de um fato, de um comportamento, de um afeto ou de um pensamento expresso por algum dos membros, foi em algum momento cristalizada em forma de um conhecimento que assumiu o valor de uma verdade absoluta, incontestável.

Antes de consolidar-se como um mito, um fantasma inconsciente se configura e é compartilhado pelo grupo. A formação da crença está associada ao sofrimento psíquico que esse fantasma impõe ao grupo, o qual, para evitar a confrontação com o mesmo, cria a crença como proteção. Porém, ainda que o mito revele um aspecto negativo, ele serve igualmente para vincular os membros da família, que compartilham do mesmo pensamento, dando a eles o sentimento de identidade e de pertencimento ao grupo, de acordo com Eiguer (2009).

A maioria dos mitos é inconsciente, mesmo que sua narrativa seja consciente e conhecida pelo grupo, porque seu caráter vital e de verdade absoluta não são perceptíveis. Perceber a presença do mito e colocá-lo em questão, portanto, é saudável para a constituição de um indivíduo ou do grupo familiar, todavia, trata-se de uma tarefa complexa e delicada, porque interfere diretamente no sentimento de identidade familiar (Eiguer, 2009).

As famílias que desenvolvem mitos intergeracionais permanecem em contato com suas raízes e são mais resistentes aos mitos de origem social, segundo o autor. Os mitos sociais têm um caráter simbólico e são elementos constitutivos do psiquismo e da identidade porque, para Eiguer (2009), exercem uma influência forte sobre o vivido e sobre os comportamentos dos indivíduos, dos grupos, das instituições em função de apresentarem teorias incontestáveis quanto à sua validade por atribuírem uma significação fixa a um fato da realidade. 
Ainda para Eiguer (2009), o mito social deve ser compreendido como uma representação social. Esse autor se apoia em Guimelli (1967), para quem as representações sociais "abordam (...) o conjunto de crenças, de conhecimentos e de opiniões que são produzidas e compartilhadas pelos indivíduos de um mesmo grupo em relação a um dado objeto social"30 (Guimelli, 1967, citado por Eiguer, 2009, p. 32, tradução livre do autor). Assim, as representações sociais atribuem uma significação aos fatos da realidade, e, por isso, devem ser entendidas como uma parte significativa da cultura.

Retomando nosso contexto contemporâneo sociocultural, Losso e Losso (comunicação em congresso, 31 de julho de 2010) interpretam as condições sociais que interferem nas constituições familiares, através da formação de mitos sociais. Percebem na sociedade contemporânea um enfraquecimento da transmissão dos mitos familiares, em função de um déficit do contrato narcisista, interferindo justamente nos processo intergeracionais dos mitos familiares, causando falhas nos processos de transmissão e, dessa maneira, os mitos sociais assumem uma prevalência no ambiente familiar, como propõe Eiguer (2009).

Segundo Losso e Losso (comunicação em congresso, 31 de julho de 2010), dentre os mitos atuais, fabricados socialmente, destacam-se: 1. o "mito da autogeração", nascido em uma sociedade em que a tradição perdeu suas forças e a tendência é de se negar as origens, como um modo de se evitar um risco de uma desilusão narcisista; 2. o "mito do consumo e da possessão", ditado pelo consumismo que sustenta a crença de que é como se todo o tipo de falta pudesse ser preenchida por objetos; 3. o "mito do homem e da mulher de êxito", em que o ideal de homem e mulher contempla ser sempre bonito, jovem, dinâmico, e capaz de adquirir bens cada vez mais caros, levando a um modo de se agrupar marcado pela fragmentação, isolamento e pelo refúgio narcisista; 4. o "mito do ideal individualista", em que são cultuados o isolamento e o desprovimento de vínculos; 5. o "mito do individuo produtorconsumidor", em que o indivíduo é reduzido a uma unidade produtiva que se foca em função das exigências do lucro máximo, para que possa revertê-lo por consumo; 6. o "mito do imediato e da imagem", numa era em que o modelo do computador nos faz pensar que sempre estamos perdendo tempo, em que prevalecem modelos de imitação e não de identificação; 7. o "mito da independência", em que o ideal, novamente, está em o indivíduo independer-se dos outros; e 8. o "mito da idealização do controle", em que tudo que escapa do controle deve ser descoberto e controlado.

\footnotetext{
${ }^{30}$ Tradução livre do autor: "recouvrent (...) l'ensemble des croyances, des connaissances et des opinions qui sont produites et partagées par les individus d'un même groupe à l'égard d'un objet social donné" (Guimelli, 1967, citado por Eiguer, 2009, p. 32).
} 
Para os autores, esses mitos, nascidos no ambiente social e fazendo parte de nossa cultura, trazem consequências para a família contemporânea. Eles destacam o enfraquecimento dos vínculos internos, na família; a falta de confiança entre seus membros; falhas nos processos de identificação e subjetivação, numa sociedade em que a ação tende a ocupar o lugar do pensamento; falhas nas funções de apoio; além do predomínio das funções projetivas de ódio, a desesperança e angústias persecutórias, como consequência das falhas anteriores. 
Capítulo IV

Objetivos

\section{O6jetivo Geral}

Compreender a construção subjetiva de adultos que optam por não se vincular amorosamente, de maneira compromissada, em meio às condições contemporâneas de existência e à herança psíquica familiar.

\section{Objetivos Específicos}

- Entender, em cada construção subjetiva, o modo singular como as condições socioculturais e econômicas de existências atuais e a herança psíquica se articulam com a opção por não ter um vínculo amoroso compromissado.

- Investigar se três fenômenos contemporâneos - "modelo tecnológico", "narcisismo moderno" e "consumismo" - estão presentes nas características subjetivas dos adultos participantes e como esses fenômenos se relacionam com tal tipo de opção. 
Capítulo $\mathcal{V}$

Método

\section{Materiais e Método}

\subsection{Participantes}

Nesta pesquisa, o foco esteve em entrevistar seis participantes adultos, de ambos os sexos e de orientação heterossexual ${ }^{31}$, de classe média, na idade entre 25 e 35 anos, que não tivessem tido nenhum tipo de vínculo amoroso compromissado por pelo menos um ano, que não desejassem ter e que não tivessem filhos, até o momento da realização da investigação.

No convite aos participantes, foi utilizado o termo "solteiro por opção", compreendido como um correspondente social para o que, nesta tese, está sendo compreendido como a opção por não se vincular amorosamente de maneira compromissada, porque é dessa forma que esses participantes se autodenominam, além de ter sido um termo interessante para o processo de seleção dos mesmos, visto que, ao se denominarem como sujeitos dessa opção estavam assumindo a responsabilidade por essa escolha. Todavia, consideramos que essa opção só poderia ser compreendida como válida para o momento de vida atual do participante, já que não se teria como acompanhar esse processo de escolha por anos.

Quanto à opção de restrição da classe social, Bourdieu (1982) assinala que a camada média da população se move numa trama que busca, a todo tempo, naturalizar suas formas de relação com o consumo de bens, tornando-os simbólicos, transformando, pautando-se e reproduzindo "valores" que garantem a esses agentes um tipo de relacionamento mais intenso com aspectos da vida cultural. Assim, produzem condutas muito menos determinadas pela condição material e muito mais por uma posição definida dinamicamente, o que garante pensar que seus recursos simbólicos e materiais lhes permitem uma maior disponibilidade para interagir com "valores novos" e "discursos" próprios da contemporaneidade.

\footnotetext{
31 Restringimos analisar casos de participantes cuja orientação fosse heterossexual, para que outros dados referentes à escolha homossexual não interferissem na análise dos dados.
} 
O estabelecimento da faixa etária dos participantes está associado à análise dos dados demográficos do IBGE $(2010)^{32}$, da qual depreendemos ser esta a faixa em que os indivíduos têm procurado atualmente estabelecer um relacionamento amoroso estável, o que significa residir junto. Ademais, os participantes nessa faixa etária caracterizam-se por pertencer a uma fase do ciclo vital posterior ao período da adolescência e da juventude (períodos intermediários de experimentação de valores, de papéis sociais e de identidades) e, por isso, vivenciam uma fase de consolidação da identidade, com possibilidades de participação política e social, de procriação e trabalho (Salles, 2005).

Como dado de composição da amostra, todos os participantes moravam sozinhos no momento da entrevista e apresentaram-se com ensino superior completo, estando alguns em curso de pós-graduação em andamento. Embora não tenhamos restringido o grau de escolaridade como requisito para a seleção da amostra, o que algumas pesquisas apontam é o impacto que esse dado exerce sobre as escolhas, no âmbito da maternidade e da conjugalidade (Antunes, 2010).

\subsection{Instrumentos Vtilizados}

Para o desenvolvimento da presente investigação, elaboramos um roteiro de entrevista semidirigida, que consiste num campo definido de perguntas abertas, no qual o entrevistado pode transitar livremente.

O roteiro de entrevista (Anexo C) foi composto por quatro partes. A primeira parte é referente à obtenção de dados gerais dos entrevistados. A segunda parte visou a compreender a dinâmica familiar, por meio da história de vida do entrevistado, da história da família, do lugar que ocupa nesta, do tipo de relação que estabelece com os membros da família de origem e com o legado familiar. A terceira parte foi constituída por temas que objetivaram compreender características da subjetividade desses indivíduos (valores, formação da identidade e relação desta com as figuras parentais, importância das atividades profissionais, grau de confiança, hábitos, planos e projetos frente ao futuro etc.). E a quarta parte pretendia

\footnotetext{
32 Os dados do IBGE (2010) relevam que, entre as mulheres, as maiores taxas de casamento ocorrem na faixa etária de 20 a 29 anos (desde o ano 2000), mas que essa taxa vem aumentando consideravelmente, na faixa etária de 30 a 34 anos, enquanto, na de 15 a 19 anos, vem diminuindo. Entre os homens, as maiores taxas de casamento ocorrem entre a faixa etária de 20 a 34 anos, embora a faixa etária de 30 a 34 anos também venha aumentando, desde $o$ ano 2000.
} 
compreender as motivações da opção por permanecer sem um vínculo amoroso compromissado.

A construção desse roteiro de entrevista, de modo geral, baseou-se no estudo de Silveira e Wagner (2006), que, através de entrevista semidirigida, buscaram abordar aspectos da estrutura e dinâmica familiar para a avaliação do contexto social atual, nos projetos e motivações dos sujeitos, ao estudar o fenômeno de adultos que permanecem na casa dos pais.

A segunda parte do roteiro baseou-se em teóricos, como Aberastury (1987) e Mannoni (1986), que visaram a compreender a dinâmica familiar através de entrevistas semidirigidas. Na terceira parte, os temas foram pensados a partir do conceito de subjetividade (Freud, 1921/2006; Kaës, 2005, 2011), que guarda relações com o conceito de identificação (Kaës, 2001), considerado por este autor como o principal mecanismo envolvido no processo da transmissão psíquica entre gerações; paralelamente a aspectos do comportamento e valorativos (hábitos, valores, comportamentos sociais, capacidade de confiança etc.) capazes de capturar e demonstrar as interferências das condições socioculturais e econômicas, na constituição da subjetividade. Por sua vez, a quarta parte pretendia apreender as motivações e conflitos frente ao posicionamento de não ter um vínculo amoroso compromissado por opção e em face do ideal social de casamento, nessa época da vida.

\subsection{Procedimentos}

Os participantes foram convidados para esta pesquisa após indicações de conhecidos da pesquisadora. Os contatos foram realizados através de emails, em que era feito um convite que explicava o objetivo da pesquisa. Caso o convidado se interessasse em participar da investigação e se identificasse com o perfil desejado, este retomava o contato com a pesquisadora.

Com todos os participantes, depois de explicitados os objetivos da pesquisa e aceito o convite, foi ainda necessária a anuência por intermédio do termo de consentimento (TCLE, Anexo A) assinado pelo participante, no momento da entrevista.

As entrevistas foram realizadas em até dois encontros, de no máximo duas horas, quando necessário, os quais foram propostos em locais preservados, definidos pelo entrevistado. Todo o material coletado foi gravado (mediante autorização), transcrito e posteriormente analisado. 


\section{Fundamentação Teórica do Método}

Tratou-se, portanto, de uma pesquisa de base qualitativa, cuja estruturação metodológica fundamentou-se no método clínico (Turato, 2003) e psicanalítico (Frosh, 2009) de investigação. $\mathrm{O}$ tratamento dos dados referendou-se no aporte teórico psicanalítico intrapsíquico ${ }^{33} \mathrm{e}$ vincular, além de toda a fundamentação teórica apresentada nesta tese.

O método clínico procura compreender a subjetividade através de uma perspectiva e postura clínica. Segundo Turato (2003), esse método científico de investigação, enquanto uma particularização dos métodos qualitativos, pretende, a partir de atitudes existencialista, clínica e psicanalítica, propiciar a acolhida das angústias e ansiedades do ser humano, uma aproximação e a valorização dos aspectos emocionais psicodinâmicos.

De acordo com Campos (2004), a pesquisa qualitativa se "fundamenta em uma estratégia baseada em dados coletados em interações sociais ou interpessoais, analisadas a partir dos significados que os sujeitos e/ou pesquisador atribuem ao fato" (p. 57), em que não se pretende qualquer generalização. Para Safra (1993), o método qualitativo deixa de lado a busca aparente da confiança proporcionada pelos tratamentos estatísticos, para levar em conta a participação do sujeito no fenômeno que observa.

Por fim, a entrevista, conforme Bleger (1980), é um instrumento fundamental do método clínico e uma técnica de investigação científica em psicologia. Para esse autor, nessa técnica, por meio da relação estabelecida na transferência, os determinantes da conduta e da personalidade que não se incluem entre os elementos que o participante poderia trazer, voluntária ou conscientemente, vão se configurar no campo da entrevista, algo que acrescenta uma dimensão importante para o conhecimento da estrutura da personalidade e do caráter dos seus conflitos.

\footnotetext{
${ }^{33}$ Foram utilizados os conceitos clássicos da psicanálise para a análise do material dos participantes, em complementação à psicanálise vincular: Complexo de Édipo (Freud (1924/1969), Transferência (Freud, 1916/2006), Contratransferência (Freud, 1910/2006), Imago (Laplanche, 2004), Fantasia (Freud, 1900/2006), Pulsão (Freud, 1905/2006), Objeto (Freud, 1917/2006), Identificação (Freud, 1921/2006), Falso-self (Winnicott, 1975), Objeto Persecutório (Freud, 1922/2006; Klein, 1946/1991), Posição Depressiva e Esquizoparanoide (Klein, 1946/1991), Projeção (Klein, 1946/1991), Identificação Projetiva (Klein, 1946/1991), Identificação (Freud, 1921/2006).
} 


\subsection{A psicanálise como fundamento metodológico}

De acordo com Frosh (2009), é por meio da sua capacidade de doar sentidos e de propiciar um método de investigação, que se propõe além do nível racional, que se pode conceber a psicanálise como um solo fértil para o desenvolvimento de pesquisas qualitativas.

Levando em consideração a entrevista semidirigida como instrumento privilegiado de percepção de aspectos inconscientes, o autor salienta que um pesquisador sensível e com capacidade de continência poderá captar a energia subjacente ao que está sendo dito. Sentimentos, pensamentos, fantasias, afetos despertados no pesquisador e no entrevistado, no momento da entrevista, poderão ser cuidadosamente, dessa maneira, também tomados como material de análise. Trata-se do modo como se estabelece o vínculo intersubjetivo entre pesquisador e participante, que, se puder ser percebido dessa forma, é capaz de fornecer dados preciosos, muitas vezes ocultos, podendo contribuir para um conhecimento mais profundo do fenômeno estudado.

No entanto, o autor ainda alerta que a narrativa interpretativa decorrente jamais poderá abarcar toda a subjetividade de um indivíduo. Uma narrativa, pondera Frosh (2009), nunca condensa um significado fixo: são diversos os efeitos que ela produz e múltiplos os sentidos que comporta.

\section{Forma de Análise dos Resultados}

De um modo geral, a proposta de análise pretendeu, dentro de uma abordagem qualitativa, clínica e psicanalítica, compreender a construção da subjetividade dos participantes, por meio do acesso às características da mesma e do funcionamento psíquico. Nessa vertente, destacou-se a intenção de compreender como essa subjetividade se articulava com valores e fenômenos socioculturais e econômicos analisados na introdução teórica da tese (principalmente o "modelo tecnológico", o fenômeno do "narcisismo moderno" e o “consumismo"), além do modo como o participante mostrava se apropriar da herança psíquica em sua construção subjetiva.

Não se tratou, por consequência, de traçar relações de causa e efeito, principalmente porque partimos da premissa de que o fenômeno estudado envolvia uma complexidade maior (inconsciente) e, assim, o empenho esteve em compreender o modo singular em que as condições socioculturais e econômica estavam emaranhadas à constituição subjetiva e esta aos 
componentes psíquicos de origem inter e transgeracionais que poderiam ter ligação com a opção em estudo. Ou seja, buscamos construir uma narrativa em que fosse possível representar aspectos conscientes e inconscientes, de origem sociocultural, intrapsíquica e herdada inter e/ou transgeracionalmente, que possibilitassem uma compreensão profunda acerca da subjetividade, capaz de nos levar a refletir sobre a opção de não construir um vínculo amoroso compromissado em cada um dos participantes.

\section{Aspectos Éticos}

O projeto desta pesquisa foi encaminhado ao Comitê de Ética em Pesquisa com Seres Humanos do IPUSP (CEPH-IP), e o parecer de aprovação encontra-se em anexo (Anexo B). Quando aprovado, o título do projeto era "Efeitos da fragilização dos vínculos intersubjetivos na contemporaneidade: "solteiros por opção"”, mas vale ressaltar que, embora o título tenha se modificado, em essência objetivo e metodologia se mantiveram.

Seguindo as normas de pesquisa, a pesquisadora responsabilizou-se por respeitar as seguintes padronizações, no contato com os participantes:

a) Desenvolver o projeto conforme explicitado a esse Comitê;

b) Manter em arquivo, sob sua guarda, por cinco anos, todos os dados da pesquisa;

c) Explicar a pesquisa aos convidados que participaram da entrevista e requisitar a anuência, por meio da assinatura do Termo de Consentimento (Anexo A);

d) Ao convidar os participantes da entrevista, garantir o sigilo sobre seus dados pessoais, além da liberdade de retirar o consentimento de participação a qualquer momento;

e) Encaminhar os participantes a um atendimento psicoterapêutico, quando sentida essa necessidade, com a garantia de serem atendidos em triagem na Clínica-Escola do IPUSP;

f) E oferecer uma "devolutiva" aos participantes que desejassem. 
Capítulo VI

Resultados

O objetivo deste capítulo será o de apresentar o resultado da análise interpretativa dos seis casos de nossos participantes, integrando-os num texto que diga a respeito às suas construções subjetivas e à opção por não ter um vínculo amoroso compromissado. Antes, contudo, cabe ressaltar, conforme aponta Velho (1986), que serão expostos resumos de histórias de vidas, produto de entrevistas gravadas que em nenhum momento refletem simplesmente essas gravações nem a vida dessas pessoas. De fato, trata-se da produção de um texto que é de nossa responsabilidade enquanto autores de cortes, de interpretações e análises feitas, o que culmina na delineação de um campo de arbitrariedade em que se move o pesquisador-autor.

\section{Patrícia ${ }^{34}$}

A história de Patrícia é muito interessante e fascina pelo caráter de consciência que ela aparentemente demonstra ter sobre os fatores determinantes do caminhar de sua própria vida. Inicia seu relato, no entanto, advertindo que não tinha nada de interessante para contar. Ressalta, no começo, que tinha uma família muito desestruturada, mas isso de uma maneira muito simpática e descontraída, o que deixou a pesquisadora muito à vontade em sua presença e interessada no seu relato. No fundo, pôde-se entender depois, ela sentia vergonha do que carregava, mas também uma necessidade de contar o que viveu, de forma muito viva e contagiante, ainda que um sofrimento subjacente pudesse ser claramente percebido, durante toda sua entrevista.

Aos 31 anos, a separação de seus pais, quando ela tinha 8 anos de idade, é um ponto muito mais do que marcante, é nodal, poder-se-ia dizer, no seu caso. Ela descreve o passado

\footnotetext{
${ }^{34}$ Todos os nomes adotados são fictícios.
} 
de sua família com um conhecimento misterioso, em termos de mulheres que não souberam escolher bons homens para se casar.

Na minha família todas as mulheres se separaram... Mãe, avó, bisavó... tenho uma tia que é casada, mas o casamento dela é horrível. Acho que ela é casada porque é um bom negócio ser casada com o marido dela... O casamento dela é um caos. Então desde criança eu ouço isso: que a vida delas acabou, porque elas eram casadas... Mas também elas escolheram muito mal: o meu bisavô eu não sei qual era o problema dele, mas com certeza tinha um..., o meu avô morreu de cirrose, ele era alcoólatra, e meu pai é viciado em jogo... É complicado você construir uma família com pessoas instáveis, né? Aí, desde criança, eu já tinha certeza que não queria fazer o mesmo que elas...

O relato de Patrícia sobre sua família suscitou a ideia da presença de uma imago matriarcal forte e impositiva, em que não havia espaço para a existência de homens "bons", já que eles eram vistos como frágeis, dependentes, impotentes, e (por isso) ausentes. Falamos de uma imago matriarcal impositiva, porque a saída que ela encontrou para esse dilema foi simplesmente a de não se apaixonar. Uma herança psíquica que, para Patrícia, parece não ter possibilitado conceber qualquer organização familiar diferente: ela passou a sensação de que estava condenada a fazer o mesmo que sua mãe, sua avó, sua bisavó e suas tias fizeram, e, por isso, resolvera não se apaixonar. Uma condenação dupla, inclusive, porque afetou o eixo horizontal (mãe, avó e bisavó) e vertical (tias) de vínculos. Tudo se passa como se tivesse recebido uma herança que, embora consciente, continua sem possibilidade de transformação.

A condenação aparenta versar sobre a escolha de um homem sem caráter que ainda que seja frágil a faria sofrer, porque estaria predestinado a não corresponder às expectativas exigidas por esse grupo de mulheres. Podemos perceber, por conseguinte, a criação de uma fantasia, de um mito familiar, em que a atribuição de valor positiva ao homem só se viabiliza pela via do apaixonamento, concebido como estado de transe, de perda das capacidades de raciocínio, de inteligência, porque, na sequência, este se mostraria o oposto do imaginado. Um mito familiar em que o homem é entendido como o responsável por retirar o bom senso dessas mulheres, ao fazê-las se apaixonar:

(...) eu resolvi que nunca ia me apaixonar. Porque, se o problema era esse, né? A minha mãe, a pessoa mais racional da face da terra, como ela aceitou deixar de trabalhar por causa de um homem? Minha avó também é tão firme e foi casar com um bêbado! Deus que me livre! Então, eu não queria ter isso para mim...

Assim, é como se ela fosse incapaz de encontrar um homem bom para se vincular, porque o estar apaixonada a faria se enganar e escolher o errado. Como se ela soubesse que, no fundo (pela via inconsciente), algo tendia a levá-la a se interessar por um homem que não seria bom o suficiente e que, após "seduzi-la", estragaria a sua vida e a de seus filhos. Portanto, é das "teias inconscientes" da paixão que ela procura a todo custo fugir. 
Ao mesmo tempo, não se apaixonar por outro homem significa não se desapaixonar do pai. É nítido no discurso emocionado de Patrícia o quanto ainda sofre com a separação dos pais, sobretudo a cada reencontro com seu pai. A sensação que ela deixou foi a de que, na sua fantasia, a mãe foi a culpada pelo fato de o pai ter ido embora num momento em que ela não tinha condições de lidar com essa perda, causando um trauma profundo e deixando consequências sérias para a sua vida adulta.

(...) eu era muito mais ligada com o meu pai do que com a minha mãe... Então, depois que eles separaram, eu fiquei dois anos sem vê-lo, porque meu pai também é meio complicado. A mãe da minha mãe não deixou ela ver o pai dela por 20 anos! Porque, já que ele não ia ajudar com dinheiro para criar as crianças, não ia se meter na criação deles. E a minha mãe só foi vê-lo quando estava no hospital para morrer, meu tio não quis ir ver: "Não me criou, não quero saber". Minha mãe quis e acho que foi muito bom ela ter ido. E aí acho que minha mãe estava assumindo a mesma postura que minha avó. E meu pai ficava: "Ah, como vou encontrar meus filhos, se eu não tenho dinheiro para levar no McDonald's?" Sabe? Ele não tinha noção que para mim tanto faz, sabe? [Ela usa o verbo no presente]. Aí eu comecei a passar mal, assim... Quando falava nele ou pensava nele, eu vomitava ou ficava roxa, e desmaiava... Eram umas situações muito exageradas e então minha mãe resolveu falar com ele: "Vê a menina que acho que ela vai morrer. Dá um jeito, não quero saber como você está, mas você tem que encontrar com ela!".

A hipótese que formulamos é a de que um Complexo de Édipo mal resolvido passa pelo viés do ressentimento com relação a esse pai, como se ele a tivesse preterido, quando vai embora de casa e por sua ausência posterior. Como se ele não tivesse tido forças para lutar contra esse mito familiar de mulheres que se apaixonam e depois rompem com homens ineficazes em suas funções, de sorte que Patrícia não o perdoa, inconscientemente, por isso. Por que o seu pai não foi diferente? Talvez essa fosse a sua expectativa. Ela não o perdoa inconscientemente, porque a culpa consciente recai sobre a história geracional de mulheres que repetem o mesmo tipo de relação com os homens e condenam seus filhos a uma vida sem pai. No discurso acima, é possível perceber que ela menciona o fato de seu pai ser "meio complicado", mas logo direciona a fala para a "culpa das mulheres". Ou seja, ela não perdoa o pai inconscientemente, mas o perdoa conscientemente. Trata-se de uma ambivalência, de um conflito que a mantém presa nesse nó identitário junto ao pai-fantasma. Mais a frente, no relato, ela pondera:

(...) no caso do meu pai, não acho que foi uma má pessoa, mas ele teve uma vida muito complicada, os pais dele morreram cedo, teve que cuidar dos irmãos... Ele não tem a menor noção do que é família. Na cabeça dele, ele não era um bom exemplo, uma boa influência, então, já que ele não podia ajudar, melhor que ele ficasse afastado (...)

É visível o quanto ela consegue compreender melhor os motivos do pai pelo afastamento, conscientemente. Todavia, o ressentimento inconsciente de ter sido rejeitada 
pelo pai parece ter condenado toda uma organização psíquica em função de uma desorganização na base narcísica da identidade. Nesse sentido, está presa a um vínculo mal resolvido com o pai, a um sentimento de rejeição e de decepção com relação a ele, e a todos os homens por extensão, sentindo que só lhe resta uma saída para o amor: no encontro com outro homem que repetirá os passos do pai, sobrando-lhe mais sofrimento e sentimento de rejeição.

- E agora, vocês se veem?

- Mais ou menos, eu não posso ver muito o meu pai. Eu fico nervosa, quando encontro com ele. Ele é legal, ele nunca me tratou mal, mas eu não sei...

- Ficou uma coisa muito forte, né? Uma marca.

- É... [fica emocionada]. É, com ele, eu fico abalada, mas eu vejo ele uma ou duas vezes por ano...

Ao se debruçar sobre o tema do divórcio, quando as mães são destruidoras da imagem paterna, Agrapart-Delmas (2009) observa que as meninas costumam apresentar problemas psíquicos importantes, patologias psicossomáticas, bem como problemas de identidade, afetivos e relacionais, como se mostra evidente nesse caso.

Patrícia, portanto, encontra-se presa a um vínculo edípico com o pai, porque sente que foi rejeitada por ele em pleno apaixonamento, quando "ela era mais ligada com o pai", e ainda busca o entendimento do porquê ele a deixou, atribuindo essa resposta ao mito familiar, tornando sua mãe e a geração de mulheres as culpadas.

Supomos que a repetição do modelo geracional de vínculo presume uma herança que foi passada de geração em geração sem transformação e que Patrícia se deu conta disso. No entanto, mesmo que esse seja um pensamento bastante elaborado, levando em consideração o mito geracional, se a hipótese de ainda estar presa ao pai no nível edípico estiver correta, esse discurso é também racionalizante como estratégia de defesa. Uma racionalização que a faz perder de vista toda a responsabilidade do pai, nesse afastamento, utilizando a história de vida dele como um apaziguador e não como um material de onde pudesse advir algum entendimento para a sua ausência, num quadro em que ele tivesse algum nível de responsabilidade. Podemos igualmente supor que, se a culpa consciente é da sua mãe, a inconsciente é dela. Ela não perdoa o pai, inconscientemente, mas, em sua fantasia, foi ela a responsável pelo afastamento do pai, por ser ter sido uma menina má, ou por ter sido pouco atraente ao pai, dentre outras fantasias possíveis que provavelmente guarda sobre si, visto que ela revela um processo de construção identitária bastante desvalorizada, em que resta a dúvida sobre a possibilidade de algum homem verdadeiramente amá-la. 
Concebemos ser incompreensível para uma menina de 8 anos entender que seu pai não teve pais e, por isso, tem dificuldade de assumir a paternidade de maneira adequada. Ela simplesmente precisava do seu herói ao lado dela, para protegê-la, para trazer segurança à família, à sua mãe, e para continuar o caminhar de sua estruturação emocional, valendo-se do amor que ele podia demonstrar ter por ela.

A "saúde mental" que ela diz procurar preservar, longe de um vínculo compromissado, faz pensar numa desorganização interna possível, se tivesse que lidar com essa parte da história. Encarar os fatos e perceber que a mãe não teve toda a culpa, como propõe, significa também a possibilidade perder o sentimento de pertencimento ao grupo familiar, porque estaria quebrando o mito que une essas mulheres e seus filhos, e esse sentimento poderia ser bastante angustiante. Além disso, esse processo ainda iria requerer sua capacidade de elaborar a perda e representá-la, debruçando-se sobre a ausência do pai pelo viés pai-filha. Seria então necessário o trabalho de resgatar a menina rejeitada num canto escuro do quarto, sozinha, sem carinhos, e possibilitar o nascimento de uma mulher que poderá ser amada por outro homem. Seus atrativos de mulher, da ordem do feminino, da capacidade de conquista, de amar e ser amada estão em xeque desde a infância, supomos, de sorte que conjecturamos uma fragilização na base narcísica da identidade a qual atinge a organização do passado, do presente e do futuro, principalmente pelas vias da elaboração da falta do pai.

Nossas hipóteses tornam-se mais viáveis se, compreendermos que, apesar das marcas desse destino fatal, encontrou em sua vida um homem bom, segundo ela, mas por quem nunca se apaixonou de verdade, embora tenha vivido um vínculo compromissado com ele por 7 anos. Ou seja, o mito familiar não é efetivamente tão inevitável, até porque toda a consciência que ela tem sobre sua história já lhe permitiu um posicionamento maior de sujeito em relação às suas escolhas, a possibilidade de se apropriar de sua história e elaborá-la.

Na época em que resolveu fazer um curso de graduação, decidiu-se pelo de veterinária, porém, sua mãe foi contra essa escolha, porque ela "não achava que era uma faculdade séria e que ela não devia perder tempo com os bichos". Esse rapaz era seu melhor amigo e lhe deu forças para "enfrentar" o poder materno, oferecendo-lhe recursos financeiros para que ela fizesse a faculdade. Ela aceitou a ajuda e ele lhe deu um cachorro. Esse homem tinha as forças para enfrentar o mito familiar, mas ela só o quis enquanto instrumento nessa função, embora através de um vínculo amoroso.

O cachorro durou 7 anos, o tempo em que ficaram juntos. Toda a relação, no fundo, era mediada pelo cachorro, quase de amizade, protegendo-a dos outros homens, podemos 
pensar. Era ele quem comprava comida para o animal e usava isso como chantagem para que ela não o deixasse. Ela não pôde se apaixonar por esse rapaz, talvez, muito mais do que a inexistência de algum interesse por ele, como deixa transparecer no relato, dando a impressão de ter sido simplesmente alguém útil em sua vida: “(...) eu precisava de alguém para me apoiar". Ela assume que, como "jogava todas as frustrações no cachorro" - com quem aparentemente tinha uma verdadeira relação -, se sentia muito responsável pelo cachorro e não o queria ver passando necessidades (como ela passou, na infância, após a separação dos pais), por isso continuava no vínculo com o namorado, já que ela não tinha como cuidar sozinha do cachorro, comprar comida, levar ao veterinário etc. Ela fez por ela, pelo "filho do casal" (cachorro), aquilo que esperou que os pais tivessem feito.

A fragilização de base narcísica pode ter necessitado da construção de um mecanismo de defesa, em que o vínculo com o "amigo" e a identificação com a figura do cachorro a protegiam de um vínculo real com outra pessoa que certamente a faria sofrer, segundo o mito familiar. O "amigo" parecia ser completamente apaixonado por ela e aceitava qualquer tipo de vínculo, desde que estivessem próximos; e o cachorro, em geral, é um animal dócil que propicia todo o tipo de projeção e de ligação de dependência emocional, porque apresenta uma disponibilidade de devoção irrestrita ao dono, um amor incondicional. Ela demonstra essa sua ligação como uma necessidade de caráter psíquico, como se, através do cachorro, pudesse cuidar dela mesma.

Eu era uma pessoa muito nervosa, brigava fácil. (...) Acho que foi muito terapêutico para mim! Perto deles [dos cachorros] eu fico calma, tranquila e eu acho que posso cuidar deles do jeito que eu quero, e eu acho que eles são felizes...

O namorado parecia também ser capaz de doar esse amor irrestrito, mas possivelmente no vínculo com ele sobrepunham-se projeções ligadas ao passado, o ressentimento com relação aos homens, além do medo de se entregar e novamente sentir-se preterida. Já no contato com os cachorros é como se ela se sentisse segura para reeditar sua história, os cuidados que não teve.

$\mathrm{Na}$ época em que seus pais se separaram, além de ter perdido o contato com o pai, praticamente também perdeu o contato com a mãe, que passou a trabalhar em três empregos para sustentar os filhos. Perdeu também os amigos do colégio, porque teve que passar a estudar em escola pública. Patrícia ainda não perdoa sua mãe, por ter escolhido esse tipo de vida, quando, segundo ela, sua avó poderia tê-los ajudado financeiramente, mantendo-a ao menos no mesmo colégio particular. Acha que a mãe foi muito orgulhosa de não pedir ajuda e ficou ainda mais difícil a relação com a mãe, quando ela mesma decide pedir ajuda para a avó, 
que aceita pagar um colégio para ela. Contudo, a mãe não aceita, afirmando que, se ela escolhesse o colégio, também deveria escolher morar com a avó, desfazendo-se da filha ingrata. Esse doloroso episódio deixa marcas na relação entre sua mãe e a avó, mas o que ela ressalta é que sua mãe prejudicou sua educação (novamente a culpa é da mãe) e, desde então, sua relação com a mãe foi também vivida como bastante dolorosa.

Ela buscava muito a ajuda da avó, com quem podia parecer contar e isso também a distanciava da mãe. Relata que, certa vez, caiu em cima do pé e a mãe não a ajudou, porque estava cansada e não era para ela fazer barulho depois das nove horas da noite: "Problema seu: fique quieta que você está atrapalhando meu sono". Pensou em ligar para a avó, ligou, a mãe ficou irritada e, por fim, levou-a ao médico. Ela não conta tudo isso sem deixar de demonstrar um coração repleto de dor: "Já sabia que ela não é uma pessoa que possa contar, eu não confio nela. Agora já consigo falar isso”, e ela novamente se refere ao passado, usando um verbo no presente. Um ato-falho, podemos pensar, sem dúvida, que representa uma memória viva e dolorosa a qual ainda ressoa sem encontrar representações que a ajudassem a acalmar essa dor de ter perdido o pai, mas também um relacionamento mais próximo com a mãe, por tê-la responsabilizado tanto.

Hoje em dia, Patrícia não tem tempo livre para sair com amigos, se divertir. Ela faz mestrado, trabalha a semana toda, inclusive aos finais de semana, e mora com três cachorros, que são sua família, enfatiza. Não acha que precisa de um "relacionamento estável" para ser feliz, o que no contexto atual entende como uma "dor de cabeça" a mais em sua vida.

(...) mas eu não acho que preciso ter um relacionamento estável para ser feliz! Hoje, por exemplo, eu prefiro não ter relacionamento e não ter dor de cabeça, então eu saio, mas para eu resolver namorar com alguém eu penso 800 vezes, principalmente porque eu sei que não vou abrir mão de nada na minha vida, porque eu sei que quero ir mais longe na minha vida profissional, quero fazer doutorado, pós-doc, quero ir para fora... E sei que com um relacionamento fica mais difícil, te limita, aí vou ter que pensar que a pessoa vai ficar sofrendo... Então, o que não me impede de viajar são meus cães. A pessoa tem que aceitar a minha vida, o que é difícil, eu nunca tenho final de semana livre... Então cada um cuida da sua vida...

Essa necessidade de proteção contra um vínculo, o vínculo amoroso, associado à suas dificuldades de base narcísica, faz pensar em uma construção subjetiva que se sustenta em fenômenos e valores da conjuntura sociocultural e econômica, à medida que a construção do seu mito individual, de que não pode se apaixonar, se junta ao mito coletivo, social, de que individualmente a vida pode seguir tranquila e feliz, caso seja uma pessoa bem-sucedida profissionalmente. Seu mito individual apoia-se nos mitos de independência afetiva, onipotência e autossuficiência. Além disso, o risco de se apaixonar, entendido como uma 
doença que pode custar sua saúde mental, é validado socialmente por uma cultura consumista e narcisista, a qual idealiza uma vida enxuta de emoções, que visa a um "estado de desapego" (Lipovetsky, 2005), trocando a vivência das emoções por medidas de proteção contra essa vivência. Da mesma forma, ela troca o vínculo amoroso pela relação com os cachorros, pelo trabalho e pelos projetos individuais, porque o outro é concebido enquanto fonte de dificuldade, de problemas, por ser capaz de interferir no planejamento individual. Assim, podemos perceber em Patrícia traços em sua constituição subjetiva ligados aos fenômenos sustentados pela sociedade contemporânea que se articulam com a opção por não ter um vínculo amoroso compromissado.

No seu caso, a necessidade de ficar sozinha nos permite pensar numa defesa narcísica em função de sua fragilidade na constituição da identidade, na medida em que a alteridade foi vivenciada como pouco provável de trazer segurança e conforto. A ausência do pai e a dolorosa relação com a mãe nos faz conceber a construção de uma imago em que a alteridade é compreendida como fonte de sofrimento. Assim, o outro, para Patrícia, naturalmente pode ser tratado de modo utilitarista, como confessa que fez com o seu namorado, por muitos anos, porque se trata de uma defesa em que esse outro não pode ser concebido como sujeito que tenha influência sobre ela. O ideal é antes de tudo o de controle sobre o outro, como propõe o "modelo tecnológico".

Tudo se passa como se ela não estivesse pronta para estar num vínculo amoroso onde as opiniões, o reconhecimento e tudo aquilo que provém do outro, tendo a potencialidade de influenciar em seu funcionamento psíquico, fosse-lhe possível de ser vivenciado. Parece-lhe insuportável, devido a sua incapacidade de elaborar essas interferências positivamente, em função das perdas que teve durante a vida, mas também em virtude do contexto sociocultural, que, como apontou Kaës (2005b), não facilita elaborações e a função do pré-consciente. Resta-lhe a sensação de que o julgamento do outro sobre ela será o de condenação, de rejeição, de incompreensão. O outro será levado em consideração somente quando a incompatibilidade não for aparente, nenhum conflito existir no vínculo, enquanto não for realmente um outro: "A pessoa tem que aceitar a minha vida". Não há, portanto, uma disponibilidade real de reconhecimento do outro nela; de reciprocidade de sentimentos que supõe o investimento no vínculo; e de ser responsável pelo outro: "E sei que com um relacionamento fica mais difícil, te limita, aí vou ter que pensar que a pessoa vai ficar sofrendo...” Em outros termos, podemos pensar numa indisponibilidade psíquica de trabalho de elaboração exigido quando se está intimamente ligado com a alteridade. 
Ainda é possível perceber, nesse mecanismo de Patrícia, um funcionamento psíquico baseado na recusa da realidade, porque era visível à pesquisadora que não estava tudo bem a ponto de conseguir encontrar a tal felicidade numa vida preenchida por trabalho e cachorros. Aspectos da contratransferência revelaram sentimentos de admiração por ela, pela força que precisava fazer para lutar contra a "maré geracional" da qual tem consciência e procura se esquivar, um certo sentimento de carinho e de cuidado do qual a pesquisadora sentiu que ela precisava, além de compaixão pelo modo como se envergonhava da "desestrutura" da sua família, de sua história. Era preciso cuidado com um vaso de cristal que aparentava ser de ferro. Uma organização psíquica precisando de reparos para ganhar integridade e uma natureza mais consistente. Isso ela provavelmente encontra no contato com os cachorros, que diz, inclusive, ser terapêutico para ela.

Interessante pensar no fato de que ela sente que faria alguém sofrer num relacionamento, porque pretende seguir uma carreira acadêmica. Pode-se entender, nesse caso, que para ela ter ambições profissionais é incompatível com um vínculo amoroso que não resultasse em sofrimento para o outro. "E sei que com um relacionamento fica mais difícil, te limita, aí vou ter que pensar que a pessoa vai ficar sofrendo...". Isso nos remete ao fato de que uma das razões das desavenças entre os pais era a necessidade da mãe de trabalhar, que o pai não permitia, o que ela deve ter vivido na infância como fonte de brigas entre os pais, e que projeta no futuro.

Ao mesmo tempo, isso demonstra uma identificação com a mãe e a impossibilidade de transformação da herança geracional. Essa identificação parece resultar de uma aliança inconsciente em que os homens ficam excluídos de um grupo de mulheres fortes e trabalhadoras. Uma aliança que, ao mesmo tempo em que lhe oferece o sentimento de pertencimento ao grupo familiar e identidade, a mantém alienada. O processo de subjetivação implica desfazer-se das alianças inconscientes e alienantes, para possibilitar a construção de uma história criativa. Supomos que essa aliança permanece inconsciente, porque a ajuda a sustentar sua defesa narcísica, seu sentimento de pertencimento a um grupo, seu mito individual e familiar, e sua fantasia de que tudo foi culpa da mãe e não do pai, do qual ela se desapaixonaria, dessa forma. Ou seja, elaborar sua herança significa uma desorganização e a necessidade de reorganização de toda uma construção subjetiva.

Podemos ainda pensar num contrato narcísico com os pais, o qual ficou enfraquecido por causa do desaparecimento do pai e dos conflitos com a mãe, deixando-a sem rumo, muito mais ligada a um passado incompreensível, num deserto sem futuro, visto que, por enquanto, só sabe o que não quer para o seu futuro. Para Patrícia, tudo ainda gira em torno dos pais. No 
final da entrevista, ela confessa à pesquisadora que imaginava que esta iria dizer para ela que "tudo era problema dos meus pais". Quer dizer, pela via da projeção, podemos entender que isso é o que ela no fundo realmente pensa. Patrícia precisa elaborar suas perdas, para poder seguir em frente.

Não que eu seja "máster" apegada com as coisas materiais, mas é complicado... A gente tinha de tudo, judô, natação, toma quantos litros de leite você quer. Você não tem noção do que é não ter! E daí de um dia para o outro você não tem nada, mas o que eu mais sentia falta era da companhia deles [dos pais]...

Foi, sobretudo, a presença e o carinho dos pais que perdeu, o que torna o processo de representação da falta muito mais delicado já que afetou, como supomos, a base narcísica de sua identidade. De acordo com Aulagnier (1979), é por meio do contrato narcísico que a criança em formação se encarrega dos projetos dos pais, para dar continuidade à família e planejar seu próprio futuro. Sem a elaboração dessas perdas, não é possível para Patrícia imaginar projetos futuros que sejam da ordem do compartilhamento, isto é, de planejar-se em uma nova família. Ela sabe que existe uma saída para seu dilema, quando diz que a mãe, as tias e a avó escolheram errado, pois, do contrário, nem teria percebido o "erro". Até porque seus pais se casaram novamente e, apesar de passar quase despercebido em seu relato, eles estão bem em seus novos relacionamentos. Assim, é como se ela realmente não estivesse pronta para um futuro possível ao lado de alguém. No final da entrevista, ela assume que, se algum dia vier a ter outro relacionamento estável, será preciso que esteja apaixonada, porque percebeu que sem paixão não tem sentido, revelando também a possibilidade e o desejo guardado, dito somente ao final da entrevista pelo seu caráter terapêutico, imaginamos, já que realmente foi uma experiência intensa e significativa, tanto para pesquisadora como para a participante.

Portanto, nesse caso, conjecturamos que um contrato narcísico enfraquecido com os pais e o "excelente exemplo" de sua família não ajudou a criar "o espaço onde o eu pode advir" (Aulagnier, 1979).

o excelente exemplo da minha família não me estimula, porque também sei que tem pessoas que conseguem ter ascensão na carreira e ter relacionamento estável, mas eu não tenho essa ilusão, sei que são bem poucos, e com certeza não vou priorizar um relacionamento estável por ter medo de ficar sozinha, e abrir mão da minha sanidade mental, não...

Concebemos que falhas nos contratos narcísicos e sua impossibilidade de conscientização da aliança inconsciente, formada com a mãe e com o grupo de mulheres da família, não promoveram um ambiente propício ao processo criativo de elaboração da herança. Sem essa transformação e apropriação da herança, passando por um fortalecimento 
egoico e pela capacidade de confiar mais no outro, parece-nos penoso o processo de se vincular amorosamente de maneira compromissada, porque será o vínculo que irá requerer dela todo esse processo de elaboração.

Patrícia apresenta, por conseguinte, a história de uma transmissão que, embora consciente em alguns aspectos, ainda é sem possibilidade de transformação, por não ter conseguido construir um espaço apropriado de elaboração e de construção subjetiva. As condições socioculturais atuais, ao promover falhas na sustentação de espaços para "colocar aquilo que encontramos" (Winnicott, 1975), não a auxiliam igualmente na apropriação de sua herança psíquica. Isso quer dizer, ainda que sua história familiar tenha contribuído para a estruturação de seus conflitos, o modo de resolvê-los (mecanismos de recusa, defesas narcísicas, dificuldade de construção de vínculos, dificuldade de elaboração, de simbolização, de sustentação e transformação pulsionais etc.) estão em consonância com as dificuldades psíquicas sustentadas pela organização sociocultural.

\section{Gustavo}

Gustavo é um rapaz de 29 anos que aparenta ser muito mais jovem, como ele mesmo confessa: "acho que sou meio Peter Pan, no fundo". A sensação que ele passou é a de que tem se empenhado em construir uma vida interessante, onde toda a espécie de compromisso e responsabilidade que o incomodam pode esperar, para que possa aproveitar ao máximo sua juventude, fazendo principalmente o que gosta.

Seu desejo pela liberdade e o fato de priorizar atividades que envolvam o prazer nos fizeram pensar que suas características muito se assemelham com a de um libertino, como descritas por Eiguer (2010). Contudo, não apenas. Como aparentemente estava bastante preocupado em demonstrar o quanto ele era interessante, inteligente, simpático e legal, foi-se delineando, no decorrer da análise desse caso, uma leitura cujo nó identitário se encontra entre sua necessidade de aproveitar a vida e sua desconfiança com relação aos próprios atributos os quais insistia em demonstrar que possuía, revelando a sensação de certa insegurança sobre si mesmo. Ambas as motivações culminando no fenômeno da postergação.

Terminada a graduação em administração, começou a trabalhar num emprego com um chefe que muito o incomodou, porque não o permitia, segundo ele, a liberdade de exercer sua profissão da maneira como acreditava ser a melhor. Percebeu logo que precisava encontrar outro jeito de trabalhar, mais independente, porque sua realização pessoal estava acima de sua 
vontade de ganhar dinheiro. Assim, resolveu voltar para a faculdade, onde encontrou uma forma de ocupação desenvolvendo projetos para a instituição, começou também a fazer mestrado e a organizar encontros para os ex-alunos.

Embora tenha suas razões, como esta de perceber seu desejo para ser professor, não podemos deixar de pensar nesse movimento semelhante ao daquela pessoa que se assusta com o que vê e prefere retornar para o território conhecido. No caso dele, mais provavelmente, como aquele que se incomoda com o que vê, já que parece ter condições de criação e de desenvolvimento de projetos, e resolve retornar para um lugar mais protegido e, por isso, confortável. Fenômeno parecido ocorre no âmbito da amizade: para ele, em função de os amigos estarem quase todos casados, com filhos pequenos, começou a passar mais tempo com amigos mais novos em termos de idade, que não lhe cobram um casamento nem trazem o incômodo de sentir o outro em uma situação de vida diferente da sua.

Assim, Gustavo vive entre o seu mestrado, as atividades que organiza na faculdade, os projetos com os quais trabalha, os amigos, as festas e saídas noturnas diárias, seus cursos de dança, projetos fotográficos e suas expedições pelo mundo, porque gosta muito de viajar. São muitos, na verdade, os projetos com os quais se envolve. Possui uma vida bastante movimentada e aparentemente muito interessante, não fosse o fato de a pesquisadora ter ficado com a sensação de que havia algo de entediante nesse "amontoado de coisas" que parecem também servir de "tapa buracos" para preencher a vida:

(...) e eu também gosto dessa coisa de ver as pessoas aprendendo e se desenvolvendo... Eu tenho um lado de educador, assim... dar aulas. Eu ia começar esse semestre, mas aí não deu certo, tive que fazer umas aulas de interesse pessoal à noite, achei que até que foi uma boa deixar para o ano que vem... Daí para complementar esses itens falaria da área de lazer: gosto muito de fotografia, tem uma câmera que eu viajo... Eu gosto de mochilar, eu viajo muito para o sudeste da Ásia, América Central, América Latina... Agora eu acho que vou para o Irã. Eu gosto de umas coisas bem loucas assim e gosto de... Eu tenho muitos amigos de várias idades, da minha sala, da Atlética, meus primos de Guarulhos, tanta gente para dar atenção que eu quase não dou conta, fico todo dividido cada hora... E também gosto muito de dançar, eu comecei a dançar em março do ano passado e hoje eu faço doze horas por semana, sapateado e dança social: sei dançar tango, bolero, gafieira, salva, merengue, tudo! E como eu tenho facilidade, eu pedi para pular de nível então estou fazendo três níveis no mesmo semestre! E como disse das causas sociais... eu já fazia voluntariado em projetos sociais na faculdade (...)

Nessa passagem, além do caráter "preenchedor" que essas atividades parecem ter em sua vida, observa-se igualmente sua necessidade de precisar adiar as atividades que envolvam algum tipo de responsabilidade, além da de ter muitos amigos. As aulas que "teve que fazer à noite", no lugar de começar a dar aulas, foram as de dança. Não contou de nenhum amigo em especial ou de nenhuma pessoa que tenha feito diferença em sua vida. A sensação era a de 
estar apresentando sua vida num palco, num espetáculo em que a alteridade era concebida com uma espécie de público, uma massa, para os quais precisava demonstrar um "bom desempenho", agradando-os na medida do possível e, quando não isso acontecesse, trocando o seu público:

Então, o pessoal tá casando... Ah, é bom, porque nas festas tem várias madrinhas! É sempre triste, porque as pessoas fazem um pouco de pressão, uma coação. Da sala só tem eu e mais outro solteiro. E daí o que eu faço: começo a sair com amigos mais novos..., só que daí todos tão namorando, daí eu saio com meus primos de Guarulhos que também não querem nada sério...

Sua condição de "solteiro por opção" é uma espécie de orgulho que procura sustentar através de seus planos, desejos de aproveitar a vida, de ter liberdade, um tanto quanto desmedida, que o dispersa e parece não lhe permitir focar seu futuro. Em seus planos, ele pretende realizar "um papel social que cause impacto, ou mesmo um doutorado, ou mesmo desenvolver uma empresa...". Contudo, ele ainda poderia "virar fotógrafo profissional, ficar uns dois anos viajando, poderia ficar um ano nos 'médicos sem fronteiras', porque cumpro alguns requisitos... Ainda bem que o mundo é feito de opção, né?”.

Gustavo apresenta um dos efeitos em sua subjetividade de uma sociedade aberta às diversas possibilidades: não consegue focar seu futuro, nem priorizar projetos. Parece que seu ego fica dividido entre as diversas atividades: "no elevador penso na roça, na roça penso no elevador” (C.D.A.). E num belo dia acorda de manhã e fica aparentemente entediado, sem rumo: "Tem dias, como hoje, eu acordei as 8 h fiquei olhando para o teto, o que vou fazer hoje à noite...? Acho que falta um pouco dessa constância". Uma constância, segundo ele, que não existe e da qual sente falta, isto é, de uma vida mais regrada, com horários de trabalho definidos.

Podemos pensar que essa instabilidade, a qual tem por pano de fundo uma subjetividade que se deixa levar à favor da maré e dos desejos, articula-se com a escolha por não ter um vínculo amoroso compromissado, visto que tudo indica que ainda não pôde conceber nenhum tipo de projeto a envolver compartilhamento. Ou seja, mais que liberdade de expressão, em sua construção subjetiva são os projetos individuais que se sobrepõem aos coletivos, suas necessidades narcísicas. Gustavo exibe uma construção subjetiva bastante voltada para si, dificuldades em lidar com a frustração, num tipo de defesa narcísica em que, quando se sente incomodado, não lida com o incômodo, mas muda de "público", foge do problema. Os fenômenos do narcisismo e do consumismo têm o seu lugar em sua constituição subjetiva, sobretudo porque somente o que é dele interessa, de sorte que o outro passa a ser visto como objeto, fonte de prazer e pouco subjetivado. 
(...) para todos os meus projetos do futuro não há espaço para uma mulher. Inclusive, quando eu percebo que estão gostando de mim, eu digo: "Olha, preciso falar que não vou mais ficar com você... Acho que eu vou te machucar, porque eu não quero nada sério...” Acho que as pessoas querem a segurança e a procriação da espécie...

A despeito de explicitar sua preocupação em ser honesto e sincero com o outro, com esta última frase ele mostra sua capacidade de racionalizar os sentimentos alheios, para se proteger da influência que pudessem ter sobre ele.

O fato de não existir um espaço para uma mulher em seus planos para o futuro vincula-se à sua necessidade de que esse futuro seja glorioso. Para Gustavo, é como se nada menos do que almejar "fazer o maior, o melhor e o mais difícil" lhe fosse satisfatório. Ele confessa poder contar com uma "capacidade de resiliência" que lhe faculta recomeçar seus projetos até que fiquem como pretendia, revelando certa idealização e necessidade superegoica de superar-se. Isso ainda sustenta nossa conjectura de que sua necessidade de aparentar ser uma pessoa bacana, inteligente etc. não condiz com sua percepção interna, porque provavelmente está muito mais ligada a uma exigência constante de superar-se do que a esta que apresenta, de contentar-se com suas qualidades.

Foi nítida também à pesquisadora sua necessidade de "cutucá-la" durante a entrevista, de chamar sua atenção não só para as qualidades dele, mas procurando "desprezá-la" em sua condição de mulher, de psicóloga, de estar fazendo doutorado e de ter 29 anos. Assim que chegou para a entrevista, fez diversas perguntas à pesquisadora sobre ela e sobre a pesquisa, deixando-a um pouco confusa. Dentro do desenvolvimento de nossa hipótese, cabe pensar que se tratava de um mecanismo de defesa, porque a presença dela o fez admirá-la e, lidando mal com a estima de si, admirá-la o incomodou, supomos. Explicando a diferença de sua condição com a dos seus amigos, ele afirma:

Porque tenho ambições e expectativas quanto à realização profissional e social e isso [ter um vínculo compromissado] vai atrapalhar nos planos. Fazendo uma comparação: meus amigos se formaram, foram trabalhar num banco, e tão numa carreira ali, entendeu? Já começaram a ganhar bem, os seus sete mil aí... E aí também imagino que pela idade das meninas... Ah desculpa, você tem 29! Por questão natural, quando a mulher se aproxima dos 30, dado ao auge da feminilidade, elas ficam mais desesperadas, e ficam cutucando no ouvido deles... E eles "Ah, já tô ganhando bem, já posso comprar um apartamento" e daí eles vão e casam. Mas eu não, tenho outras ambições e expectativas (...)

Nesse discurso, ele revela uma incompreensão quanto à opção dos amigos pelo casamento, o que para ele só pode ser entendida pelo auge da feminilidade das mulheres, aos 30 anos, que ficam cutucando seus namorados para casar. Ao mesmo tempo, tratava-se de um discurso endereçado à pesquisadora que, por meio da contratransferência, sentiu certo incômodo e rejeição, como se ele quisesse lhe dar a impressão de estar numa posição 
privilegiada em relação a ela, ou em relação às mulheres. $\mathrm{O}$ incômodo dele, em razão de suas expectativas internas, é inserido no outro, naquele que ele admira, através do mecanismo de identificação projetiva, revertendo a situação a seu favor. Quer dizer, atribuindo ao outro os atributos que não suporta em si, no caso dele a rejeição, sobrando-lhe os bons. Assim, ele, racionalizando, entende que sua condição é favorável comparada à de uma mulher e, por isso, sua vida mais interessante do que a dos amigos que se casaram cedo, inclusive porque ele descobriu que pode adiar ter um compromisso:

(...) porque uma mulher de 29 pode atuar num ramo de 28 a 40. Um cara de 29 tem um leque de opções de idade... Ela não vai ficar com um cara de 25, vai ficar de 28 a 40... Um cara de 40 pode ficar com de 20 até uma quarentona bem sarada... né?

Ainda que estes apontamentos contenham implicitamente o modo como foi se estabelecendo o vínculo com a pesquisadora, há ainda nesse comentário um traço de sua herança geracional que assegura a construção de seu mito individual: seu pai casou-se com sua mãe quando ele tinha 40 anos e sua mãe 23 anos. Estamos diante de uma dimensão importante da herança geracional com o qual se identifica e ratifica sua opção de não querer um vínculo amoroso compromissado nesse momento de sua vida. Além disso, relata que, apesar de praticamente ter tido que "crescer sozinho", porque, por causa da diferença de idade que possui com o pai, não tenha tido muito "o que conversar" com ele, sente que deve muito aos pais por sempre tê-lo incentivado em seus projetos acadêmicos. Sente-se grato pelos valores recebidos, pela forma como os pais souberam incentivar os filhos a estudar, para que pudessem ter uma "empregabilidade no futuro". Também admira o fato de ter tido uma educação que não foi protetora e que lhe possibilitou "conhecer o mundo com as próprias pernas". Portanto, podemos perceber em Gustavo sentimentos positivos de admiração e gratidão por pertencer ao grupo familiar, pela via da identificação e do contrato narcísico: “(...) meu pai com o nível educacional dele... ele não tem nem o fundamental concluído, ele conseguiu digamos sustentar a família e ter um patrimônio para poder viver bem na aposentadoria!”.

Todavia, revela igualmente traços de seu pensamento que não estão de acordo com parte da herança recebida: ele guarda um sentimento de incompreensão e quase de mágoa em relação ao pai. Ele se ressente pela falta de proximidade com o pai, que entende como um desinteresse por parte deste em aprender e continuar se desenvolvendo.

Não sei... se a gente [ele e o pai] tivesse mais proximidade, mais conteúdo para trocar! Então ontem eu saí e a mãe da menina estava com ela lá... na balada. "A minha mãe divorciou e eu trouxe ela junto". Essa intimidade assim, nesse sentido... Até porque meu pai parou de beber e fumar quando meu irmão mais velho nasceu, tem uma distância grande de idade, é outro assunto... 
Com o pai, desse modo, além do caráter de ele ter se casado tarde com uma moça jovem, parece pouco se identificar, porque o define como um pouco arrogante, sem conhecimento do mundo. Num dado momento da entrevista, afirma que não sente que seja alguém "rabugento e teimoso", como provavelmente acha que o pai foi ou é. Ou, ainda, pela via da negação (e identificação) é o que pensa inconscientemente sobre si mesmo.

Seu lema de vida é o contrário do que o pai construiu: "Viva como se fosse morrer amanhã e aprenda como se fosse viver para sempre", o que "é meio um carpe diem", ele afirma, com a diferença de que importa hoje também pensar no futuro: "Essa coisa da aprendizagem contínua acho importante". Ele pretende ser um "velho hiperativo", viver até os 100 anos, se a vida boêmia o permitir. Embora um pouco paradoxal, esse pensamento parece revelar sua necessidade de ter um olho no presente, outro no futuro e ainda outro no passado. Tomando como exemplo o pai, ainda que pelo oposto, procura reeditar a herança recebida, o que em termos de mecanismos de herança psíquica deve ser compreendido como sua capacidade de transformar o recebido.

No que tange à relação com sua mãe, contou muito pouco, porém, o bastante para sentirmos que teve uma mãe acolhedora e presente. Entretanto, admite que o relacionamento com suas duas irmãs foi um tanto conturbado, pois elas batiam nele na infância, até que percebeu que podia revidar e elas pararam de bater. Ele ainda tem um irmão do qual conta somente que está casado, com uma filha. Dos quatro, ele foi o primeiro a sair de casa, apesar de ser o caçula, porque queria fugir do trânsito da cidade para morar mais perto da faculdade; mora sozinho desde então, demonstrando condições e recursos psíquicos.

Gustavo se define como líder, de personalidade forte, mas ao mesmo tempo flexível: sente-se capaz de analisar o seu ponto de vista e refazer sua decisão sempre que necessário, ressaltando sua capacidade de considerar as opiniões alheias. Admite que essa flexibilidade lhe possibilita "dançar conforme a música" nos diferentes grupos que frequenta, embora nem sempre isso ocorra: "Às vezes erro o botão, fico mais sério com o pessoal mais louco e mais louco com o pessoal mais sério".

Ele se acha feio, "horrível", mas assume que, em compensação, Deus lhe deu o dom da "lábia", através da qual consegue conquistar as garotas. Isso nos remete novamente a pensar que não está satisfeito com a imagem que tem de si, mas que encontrou uma forma de contornar a opinião (suposta) alheia, relevando com isso que a opinião dos outros realmente o afeta, procurando se defender delas. Ele precisa do reconhecimento do outro, ainda que por meio de um mecanismo de identificação projetiva, em que o outro se sinta diminuído diante 
dele, como a pesquisadora se sentiu - e assim o admire. Numa tentativa de controlar as opiniões alheias, num mecanismo, inclusive, em que o outro, pelo viés do fenômeno do "modelo tecnológico", passa a ser disponibilizado às suas necessidades de origem psíquica.

No entanto, esse contato tem limites, o vínculo que estabelece não parece ser recíproco. Tudo se passa como se ele esperasse certo reconhecimento que realmente recebe dos amigos e das mulheres com as quais tem um romance, mas um reconhecimento que na sua fantasia se sustenta pelo seu esforço, não pelo o que realmente ele sente que é. Pela tentativa de controle da opinião alheia, pelas próprias qualidades que ressalta, nas conversas, nos encontros, não pelo que parece ser em essência. Por conseguinte, para ele, um relacionamento tem que ter um prazo adequado entre conseguir o reconhecimento de que precisa e "saltar" fora antes que um vínculo profundo possa se estabelecer e sua essência aparecer. Seu medo talvez seja o de sua "máscara" cair e a pessoa enxergar quem ele realmente é: feio e sem graça, chato, apesar da capacidade de sedução. Imaginamos que essa pode ser sua fantasia, o seu mito individual.

Ao final da entrevista, como o último relato, assume que, no seu primeiro relacionamento, com duração de dois anos, descobriu que havia sido traído - não numa balada, salienta, mas por uma história amorosa que já durava três meses quando ele descobriu. Depois disso, passou um ano sem querer ficar com ninguém, revelando sua tristeza e o modo como pareceu estar profundamente envolvido nessa história, a única de toda a entrevista. Isso pode ter abalado a confiança que tinha nas mulheres e posto à prova seu sentimento de estima de si, criando uma carapaça e desenvolvendo sua capacidade de seduzir e controlar. De onde advém, provavelmente, a dificuldade de entrar num vínculo sem sentir o receio de ser novamente rejeitado, como a pesquisadora assim o percebeu, além do surgimento da fantasia de que se aprofundar num vínculo significa perder o charme e poder se sentir preterido.

A sua necessidade de preencher todo o seu tempo com muitas atividades pode estar a serviço de idealizações e de sua necessidade de realizar projetos grandiosos. Todavia, ele diz que não é uma pessoa constante: confessa que há dias em que tem preguiça e não trabalha quase nada e, em compensação, em outros pode passar vinte horas trabalhando. Portanto, podemos conceber, dentro do desenvolvimento de seu caso, a existência de exigências superegoicas, mas também a incapacidade de atendê-las, pelo grau idealizado dessas exigências, levando-o a um movimento bipolar, da idealização e "hiperatividade" ao tédio e sofrimento, em face da sensação de incapacidade e insegurança. A "capacidade de resiliência" que ele afirma ter provém de tentativas e erros e da insistência em conquistar o que almeja. $\mathrm{O}$ fato de nem sempre conseguir o que deseja, ou o que idealiza, o torna inseguro, mas suas 
necessidades narcísicas e superegoicas de superar-se o mantém em constante busca. Dessa maneira, é como se tivesse que ter rompido com toda a possibilidade de se responsabilizar pelos outros, numa organização prioritariamente narcísica, em favor de si:

(...) o último namoro foi em 2007. Namorei um ano só, porque ela era francesa. Então... ela voltou para lá e tipo, não quero ficar namorando à distância e "não quero acelerar doutorado por causa de você, quero fazer as coisas porque fazem sentido"... e não porque... Aí eu terminei com ela no aeroporto.

Ele tem razão em dizer que precisa fazer as coisas porque têm sentido, mas a maneira como relata esse final de namoro fez parecer que esse um ano de relacionamento não teve tanta importância e que não pretende que ninguém tenha, a fim de que não seja capaz de interferir em seus planos, como chegou a declarar. A alteridade parece ter assumido um caráter de incômodo, palavra que já apareceu por diversas vezes no desenvolvimento desse relato, levando-nos a crer que é realmente assim que se sente no que concerne a um vínculo em função da possibilidade que o outro tem de interferir em sua vida, de incomodá-lo ou de traí-lo. É como se Gustavo não pudesse se apaixonar, porque, conforme exposto anteriormente, o apaixonado fica à mercê e frágil diante das opiniões e julgamentos daquele que ama. Frágil, nessa posição, tem receios de que o outro o decepcione novamente.

Tomando-se como comprometido no plano sociocultural o "lugar para colocar aquilo que encontramos" (Winnicott, 1975), em virtude de falhas nas "garantias metassociais" (Kaës, 2005b), Gustavo talvez simplesmente demonstre que, como alternativa, restou-lhe criar um espaço individual, protegido do outro, para desenvolver com calma seus projetos e futuro. Mesmo porque ele pretende se casar e ter filhos, parece poder contar com a possibilidade elaborativa para estar num vínculo, ainda que apresente dificuldades em lidar com a frustração, porque, por enquanto, simplesmente sente que um vínculo lhe custará um trabalho que julga desnecessário e incômodo.

Gustavo não demonstrou carregar uma herança psíquica impossibilitada de transformação. Não contou sobre traumas de origem familiar, guarda um sentimento de carinho e gratidão pelos pais, ou seja, pela herança que recebeu e pretende ter filhos: “(...) já fiz de tudo: mergulhar com tubarão, ficar a um metro da lava... Essas experiências, assim, vou contar para os meus netinhos". Contudo, imerso numa cultura que cultua o prazer, a liberdade, todas as formas de expressão, o divertimento e a disponibilização do outro, Gustavo, em face da oferta de opções, do incômodo com as mulheres, sentimentos de insegurança e da ausência de projetos que necessite de alguém para compartilhar, recruta suas forças em prol de seu desenvolvimento pessoal, identitário, e se diverte: 
Ah... e também porque está tão divertido! Já que tem um monte de solteira e um monte de gay no mercado, a proporção está 3 para 1. Então, eu começo a ficar mais bonito também.... Cai a exigência delas e eu começo a ficar mais bonito... Ontem mesmo, saí como uma psicóloga: ela caiu na lábia, você viu que legal? Toma cuidado comigo, hein? Tá divertido!

Novamente, um discurso endereçado à pesquisadora, alertando-a de que ele tem capacidades de conquistar uma psicóloga, como ela. Nossa hipótese, como já dito, é a de que Gustavo foi ficando assustado com as qualidades imaginadas da pesquisadora, de modo a aumentar sua necessidade de enfatizar as próprias. De toda forma, aliando esse fato à relação complicada com as irmãs, em que se sentia ameaçado e precisou começar a ameaçá-las para ter mais tranquilidade, além de depois ter sido traído no primeiro namoro, podemos conjecturar que Gustavo se sente inseguro com mulheres, cuja alteridade é sentida como ameaçadora. Isso explica por que não quer uma mulher ao seu lado para ajudá-lo na construção de seus projetos grandiosos: é como se essa alteridade fosse vivenciada, de novo, como um público ao qual ele não pode decepcionar, como alguém que o julga e não pode ajudá-lo, deixando-o inseguro e solitário nessa tarefa.

Disso tudo, concluímos que Gustavo entra no vínculo amoroso pela porta da fantasia, tendo por base esse mito individual, onde predominam identificações projetivas e a dificuldade de lidar com a alteridade como ela realmente é. A base é uma construção subjetiva que comporta uma fragilidade narcísica, o que naturalmente dificulta o processo de lidar com a frustração. Sai do vínculo com a mesma facilidade com que entra, porque o que lhe interessa por enquanto é a satisfação de, a cada nova conquista, sentir-se um pouco mais seguro sobre si.

Reunindo nossas hipóteses, Gustavo nos faz pensar numa construção subjetiva que guarda as características da libertinagem, por ser muito mais ligado às emoções e ao prazer passageiros, os quais ele busca incessantemente, sem nenhum interesse pela intimidade psicológica do outro; mas não é só isso. Tudo se passa como se, para esse rapaz, a possibilidade de aproveitar a vida tivesse lhe "caído como uma luva", numa sociedade que aprova e ratifica tal tipo de escolha ante seu incômodo em fazer diferente. Para que consiga conquistar seus planos e ter um vínculo amoroso compromissado, Gustavo precisa de mais tempo. Pudemos detectar traços de um desconforto interno, incômodo, ligados a uma imagem desconfiada de si, insegurança, uma imago feminina ameaçadora, além de um funcionamento psíquico que demonstra a existência de exigências superegoicas idealizadas e constantes, levando a certo sofrimento. 
O seu mosaico é um tanto quanto complexo, mas supomos que aborda uma dificuldade de organizar seus projetos em torno de se casar e ter filhos, muito provavelmente porque, para ele, isso significaria ter uma carreira que envolvesse ganhar um bom salário, como a dos amigos, o que, todavia, considera não fazer parte de seu perfil. Talvez não faça parte de seu perfil ir todos os dias a um banco ou vestir-se de terno e gravata, mas parece que dar boas condições de vida à sua família está em seus planos, ainda que por outros meios. Daí a idealização com os projetos grandiosos, porém, antes de assumir um vínculo, porque supomos que no fundo não tem certeza de que vai conseguir cumpri-los como almeja e não vê a mulher como sua aliada nesse processo, muito pelo contrário: como alguém que iria condená-lo pelo fracasso. Somam-se a esse quadro, ainda, o ideal de homem de êxito, ideais narcisistas, assim como os ideais de independência e controle sustentados por nossa sociedade.

Supomos ainda que a organização de sua subjetividade, envolvendo a necessidade de ficar solteiro e de inventar um futuro diferente daquilo que o pai the propôs como herança, pode tomar como referência o contexto de uma sociedade onde há liberdade em torno das possibilidades e das opções. Ou seja, concebemos suas dificuldades em torno da organização de projetos compartilhados também como produto de uma sociedade que não cultua a tradição, mas, ao contrário, a liberdade, a individualidade, o direito de se reinventar, o que, nesse processo desancorado, pode se reverter igualmente em uma dificuldade de priorizar projetos e planejar, de fato, o futuro.

No entanto, Gustavo tem muitas capacidades elaborativas e, a despeito de não saber muito bem por onde ir, está caminhando e desenvolvendo seus projetos presentes. De qualquer modo, Gustavo apresenta uma construção subjetiva criativa diante das possibilidades e impossibilidades de existência contemporânea, em que a opção de não ter um vínculo amoroso compromissado se encaixa ao seu perfil e o ajuda a continuar pensando sobre sua vida e seus projetos. Parece que essa opção faz parte do seu processo de apropriação da herança psíquica e de transformá-la, criando uma construção subjetiva que realmente lhe pertença.

\section{Isabella}

Simpática, simples e complexa, com conflitos aparentes, Isabella, aos seus 34 anos, parece ainda viver um processo de repensar sua vida depois de muito já tê-la repensado. 
Simples e complexa, exatamente assim, porque, para a pesquisadora, foi muito simples ouvir o que ela tinha de complexo para falar e, ao mesmo tempo, muito complexo ouvir o que ela tinha de simples para dizer. De qualquer forma, existe uma certa confusão, conflitos quase inerentes, quando pensamos em Isabella.

Não se prolongou em detalhes, todavia, o pouco que relatava era sempre muito significativo e vinha, frequentemente, carregado de emoções.

- O que marcou muito na minha vida foi muita mudança de casa... Então, sempre foi difícil com escola, não consegui ter um relacionamento com os coleguinhas de sala... Eu morava em Brasília, depois fui para Belo Horizonte, São José dos Campos... São Paulo...

- Em função de alguma profissão?

- Meu pai, que dava aula num lugar, depois dava aula em outro...

O pai era professor universitário e se mudava com o passar do tempo, mas não tão pouco tempo assim, a ponto, como ela diz, de não ter conseguido estabelecer relacionamentos com os coleguinhas das escolas por onde ela passava. Ficava cerca de cinco anos em cada lugar, tempo razoável para uma criança criar vínculos, supomos. Contudo, não era assim que sentia e, seja porque a mãe se incomodava e acabava este sendo um discurso corrente em casa, seja porque ela tenha sentido na pele essas rupturas, seja ainda porque uma vez, tendo perdido a melhor amiga, tenha resolvido não mais se vincular profundamente a mais nenhuma... - com efeito, realmente essas mudanças constituíram algo que a "formou", como ela diz, através do "desapego!"

Nunca ninguém me reconhecia nos lugares que eu ia... As pessoas me perguntavam: "Você é filha de "queeeem"? Eu não conheço o seu pai!" [risos]. E aí quando eu mudei para São Paulo, eu era a menina do interior, me chamavam de mineirinha...

Pelo modo como contou esse aspecto de sua história de vida, mostrando-se ainda bastante incomodada com a maneira como foi tratada, pudemos supor que esse fato muito a marcou, visto que ela enfatiza justamente aquilo que provavelmente mais a fez sofrer, durante a infância, diante das mudanças: o não reconhecimento. $\mathrm{O}$ não reconhecimento, por parte dela, das pessoas, dos lugares, das escolas, e o mesmo não reconhecimento por parte das pessoas por onde ela andava, fazendo-a não se sentir pertencente a nenhum desses lugares. A saudade, as lembranças, a necessidade do recomeço... Sempre uma "estrangeira" onde morava.

A sensação que a pesquisadora teve, ao estar com ela, é de que precisava ajudá-la a construir sua própria narrativa, ora porque parecia se perder na resposta, ora porque não entendia bem a pergunta... e a mesma sensação permanece na escrita desse caso: parece que faltam detalhes, pedaços, explicações, que existe algo que não se encaixa, como uma colcha 
de retalhos que precisa ser cuidadosamente tecida, para que pudéssemos melhor compreendêla, procurando não cair no risco de emendar qualquer retalho não existente, para que a colcha finalmente ficasse inteira!

Até mesmo porque a sensação que Isabella passa é a de que a colcha não precisa estar inteira. Não, não mesmo. Levemente costurada é o suficiente para que ela possa reordená-la depois, caso queira mudar a ordem dos retalhos. Pelo trabalho de associação livre, isso nos fez lembrar uma passagem do livro de Bauman (2009):

Nos dois extremos da hierarquia (e no corpo principal da pirâmide, presas entre eles num dilema), as pessoas são atormentadas pelo problema da identidade. No topo, o problema é escolher o melhor padrão entre os muitos atualmente em oferta, montar as partes do kit vendidas separadamente e apertá-las de uma forma que não seja nem muito frouxa (para que os pedaços feios, defasados e envelhecidos que deveriam ser escondidos embaixo não apareçam nas costuras) nem muito apertada (para que a colcha de retalhos não se desfaça de uma vez quando chegar a hora do desmantelamento, o que certamente acontecerá). No fundo, o problema é apegar-se firmemente à única identidade disponível e manter juntos seus pedaços e partes enquanto se enfrentam as forças erosivas e as pressões dilaceradoras, consertando os muros que vivem desmoronando e cavando trincheiras cada vez mais fundas. Para todos os outros suspensos entre os extremos, o problema é uma mistura das duas coisas. (Bauman, 2009, p.13-14.)

Um problema de identidade? O que Bauman (2009) procura salientar, nessa passagem, é como o consumismo interfere na constituição da identidade dos indivíduos, numa sociedade contemporânea, ao oferecer com as mercadorias a compra de partes soltas de um "kit". Não que essa questão identitária, no caso de Isabella, advenha das condições de vida contemporâneas, não totalmente, ao menos. O que estamos procurando enfatizar aqui é a percepção de um "alinhavado solto" envolvendo sua construção subjetiva, e que, embora lhe cause um incômodo, é como se Isabella não pudesse ser de outra forma.

A partir dos seus 13 anos de idade, passou a morar em São Paulo, onde finalmente permaneceu, não porque o pai tenha se estabelecido na cidade, mas porque sua mãe resolveu não mais segui-lo. A mãe havia conseguido um emprego e resolveu ficar, o que Isabella parece ter apreciado, pois, segundo ela, a mãe se tornou mais independente do pai e o casamento deles mais consolidado pela distância.

Depois de completado o ensino médio, Isabella foi passar as férias na Bahia e lá se encantou por um moço, o qual começou a namorar: "Arrumei um namoradinho". Depois de um mês, ligou para a mãe e disse que não voltava mais para São Paulo. Passados cinco meses, resolve retornar para São Paulo, porque algo da realidade do lugar falara mais alto: era uma cidade pequena da Bahia, onde ela passava sem saber muito sobre o mundo e sentiu que estava "ficando atrasada". Voltou para São Paulo, resolveu estudar e retomar a vida, que 
ficou, segundo ela, um ano parada. Foi então que entrou para o curso de Letras e começou a dar aulas de português para uma comunidade indígena.

Dei aula também... mas aí começou... ficou difícil, porque dava aula de português para alguns índios do litoral e foi por causa deles que desisti de dar aulas, porque foi meio conflituoso... Foi difícil... Aí larguei, e foi aí que resolvi tentar fazer Direito. Daí mudou tudo: larguei a capoeira, não quis mais dar aula... E fui fazer Direito. Quer dizer: fui pensar onde fazer Direito, né? Daí resolvi fazer numa faculdade perto de casa... para não ser trabalhoso, porque tinha que trabalhar também. Fiquei uns dois anos numa crise, até resolver mesmo mudar.

Conflitos e rupturas. Erros e acertos? Isabella queria "tentar fazer Direito", porque sentiu que não tinha conseguido fazer ainda?

Conscientemente, foi fazer o curso de Direito porque se apaixonou pelo material de legislação da comunidade indígena: “Nossa, é isso que quero fazer da vida!”, pensou. E realmente fez o curso, na verdade, ainda não estava formada no momento da entrevista, mas considera realmente esta uma atividade encantadora, embora não queira ser advogada, e sim trabalhar com legislação. Todavia, nesse meio tempo, passou num concurso público e trabalha numa área que não tem relação com Letras nem com Direito, mas é um bom trabalho do qual muito se orgulha, porque nesse concurso só havia uma vaga e ela a conseguiu. Não que estivesse feliz com o seu emprego, ela pretende mudar de atividade, apesar de gostar muito das pessoas com as quais trabalha ("Eu gosto das pessoas que trabalham comigo, tenho um carinho de verdade por elas...") e, ao mesmo tempo, ter dificuldade de conviver com elas...

- Eu acho que eu sou... Apesar de ser bastante compreensiva, eu sou... meio cabeça dura, eu consigo compreender o que o outro diz, mas dificilmente eu vou abrir mão do que eu penso, assim: "Ah, não, você está certo!" Se você está certo, o problema é seu! Porque eu tô certa! - E você acha que isso interfere na sua vida?

- Ah, interfere. No local de trabalho, por exemplo, às vezes eu sinto falta de conduzir as coisas de um modo mais leve...

É como se ela se responsabilizasse pelos conflitos que aparecem no vínculo como sendo somente seus. Isabella pareceu ser uma pessoa leve, porque, malgrado a confusão, não deixou a pesquisadora confusa, de sorte que não aparenta projetar no outro seus conflitos. Ela se acha uma pessoa compreensiva, na medida em que consegue entender o outro, como se tivesse a capacidade de ser empática, mas como se isso não fosse o suficiente para, às vezes, conceder-lhe a razão. Porque a razão é dela, mesmo que o outro também a tenha. Estamos no âmbito do processo de reconhecimento do outro: ela o reconhece, mas desde que esse outro igualmente a reconheça. Reconheça que nela existe alguém que pensa e tem bons argumentos. A pesquisadora ficou com a sensação de se tratar de um procedimento de defesa daquilo que 
ela é, como se sua construção subjetiva vivesse mesmo dos retalhos, que, se perdidos, a colocariam (novamente) em um conflito angustiante.

Interessante como ela aludiu a brigas por algumas vezes, na entrevista, como se a pesquisadora supusesse que ela fosse uma pessoa "briguenta": falando sobre sua personalidade, ressalta que, quando não gosta de alguém, ela "não briga, não!, que ela "se afasta!". E, contando sobre o casamento dos pais, lembra que eles de vez em quando brigavam, porém, que não era nada muito sério. Inclusive, ela toma o casamento dos pais como um modelo que gostaria de reproduzir, em função disso:

Acho que é mais ou menos o que eu tenho vontade de ter... porque... tem brigas, obviamente,
mas eu nunca vi meu pai xingando ou batendo na minha mãe! Por mais nervosos que eles
estejam, dão um berro e dizem "Não enche o saco", no máximo! Quando minha mãe resolveu
que não ia mais acompanhar meu pai na viagem, porque ela tinha arrumado um emprego
aqui, tal... eles continuaram juntos e depois o vínculo fortaleceu, acho que essa confiança que
um viu no outro, que acho muito difícil de ver por aí, eles ficaram dez anos separados e foi
esses dez anos que fez com que eles voltassem a namorar, eles se viam duas vezes por mês
mais ou menos, daí iam no cinema... Aí acho que eles construíram um casamento que eu acho
que é uma coisa legal... Agora faz cinco anos que meu pai voltou a morar aqui, minha mãe
ficou mais independente, porque ela era muito dependente dele, agora ela também tem mais
autonomia, pode se respeitar mais por ter essa autonomia...

Chamou nossa atenção a maneira como ela definiu o vínculo dos pais e como admira o modo de eles se relacionarem: a despeito das brigas, existe o respeito, por não haver violência, e um respeito e carinho que foram conquistados em parte pela distância e pela autonomia da mãe. É marcante a forma como ela parece ter se dado conta de que foi a separação dos pais, nesses dez anos de convivência à distância, que fez melhorar o relacionamento entre eles. Supomos que seu mito individual passe por aí. Ficou no ar, contudo, se acaso chegou a viver algum tipo de violência na vida, em algum dos vínculos amorosos que teve... Fantasias nossas, embasadas pela maneira como ela mesma se define: como aquela que não é capaz de abrir mão de nada pelo outro.

Nesse contexto, supomos que o casamento dos pais fica idealizado, já que, apesar de admirá-lo, é como se ela sentisse que não tem como reproduzi-lo. Parte da admiração soou como se parte dela, ou toda ela, não tivesse condições de viver um vínculo como o dos pais. Ela não tem um vínculo amoroso compromissado e não sabe se um dia pretende ter. $\mathrm{O}$ que tem é o que ela chama de "ficante", um vínculo amoroso não compromissado com um rapaz, que dura já quase um ano, embora seja perceptível o incômodo:

Eu não sei, porque esse cara que eu tô ficando... ele foi para minha casa na quinta à noite e ficou até sexta. Depois voltou sábado e ficou até terça, e eu já não estava mais aguentando! Nossa, queria ficar sozinha, queria sair do banho e ir até o quarto sem precisar falar nada, então não sei se... eu consigo, ou então o problema é ele... mas, por enquanto, não consigo me imaginar numa casa cheia de gente. (...) quando eu fui morar sozinha, já era uma necessidade 
estar sozinha! Eu morava com meu pai e com minha mãe, tinha uns 28 anos. Com a ideia de sair de casa, pensei em dividir com alguma amiga, mas depois no processo de sair de casa, começou a dar uns problemas: "Ah, eu quero aquela...”. Ah, quer saber? Não, fico sozinha! Sem conflito!

Conflitos e rupturas. Ela gosta de ficar sozinha, porque o vínculo com o outro a incomoda, fazendo-a repensar suas escolhas, fazendo-a repensar a si mesma. Isabella não parece em paz consigo mesma, e ela sabe o poder que o outro tem de influenciar em suas escolhas, pensamentos, sentimentos, e procura se esquivar disso. Evita a intimidade. Apesar da construção em retalhos, o outro deve ser evitado. A imagem é a de alguém que está atrapalhado com algo e não quer a ajuda de ninguém, porque sente que vai atrapalhar mais. É como se precisasse de zonas bem demarcadas entre ela e o outro, zonas separadas, e todo o contato que exigisse trocas fosse sentido como ameaçador do que ela é.

Ah, acho que tenho um pouco de insegurança. Porque, para fazer de verdade as coisas que eu quero, tenho um pouco de medo, sabe? Será que eu seria capaz de ser promotora? Estudar para a promotoria?

Isabella apresenta uma construção subjetiva envolta num tipo de narcisismo que procura "enxugar" as emoções, a tensão emocional, alcançar um estado de desapego e de proteção contra as emoções que o outro faz suscitar nela. Uma proteção que a faz ver o outro como objeto de suas necessidades, pouco subjetivado, em função de uma insegurança interna por receio de que um todo inteiro possa se "desmanchar". Suas inseguranças ainda a levam a repensar a vida, às rupturas e aos conflitos. Como se Isabella ficasse num contínuo questionamento sobre si mesma, em busca de aprender mais sobre si, sobre suas capacidades, entretendo-se consigo mesma, num jogo que parece vital e não tem lugar para um outro.

Aprender a dirigir foi uma de suas conquistas ressaltadas na entrevista, porque nunca achou que lhe fosse possível: “(...) eu protelava, protelava... Não achava nenhum problema em ter que andar de ônibus. Eu achei que nunca ia conseguir ter um carro meu e conseguir cuidar dele... Aí comprei um carro..." e conseguiu dirigir. Será que não sentia que tinha condições de dirigir a própria vida? No entanto, Isabella conseguiu comprar o carro e também ir morar sozinha! O pai foi contra, porque, segundo ela, esperava ver a filha saindo de casa para se casar, mas a mãe foi a favor de sua iniciativa, como se a filha tivesse entendido o recado da mãe de que é importante para uma mulher aprender a viver sozinha.

Podemos pensar em uma herança geracional que oferece modelos diversos e opostos de identificação. Quando Isabella era pequena, via os pais juntos, depois assistiu à mãe se separar do pai, mesmo não se separando, propondo um casamento à distância que, de acordo com ela, deu mais certo do que o anterior, quando viviam juntos. Finalmente, o pai volta para 
casa e ela consegue dar valor ao tipo de vínculo que construíram, no qual a diferença não gera violência, mas o respeito pelo outro. Restou-lhe a admiração por um trajeto diferente dos modelos tradicionais de casamento e uma lição de que as mulheres, quando mais independentes do marido, conseguem se respeitar mais por terem adquirido autonomia, construindo um vínculo mais satisfatório. Além disso, parece que ficou um registro, em função de diversas experiências na vida, de que a intimidade e a permanência das pessoas incomodam. Experiências, registros e sensações que geraram um conflito quanto à vivência de um vínculo profundo. Será que é por isso que se vê em dúvidas?

- Engraçado, quando eu penso em relacionamento estável é difícil desprender isso da importância que tem socialmente! Será que eu não tenho vontade de ter um namoraaaado, namoradão mesmo, porque isso me é cobrado socialmente? Ou porque eu realmente quero? Porque às vezes eu acho que eu não quero! Essa coisa de dividir conta, compartilhar da casa, fazer compras, às vezes acho que isso é importante... E eu queria viver isso, mas como na prática isso não dura uma semana, eu já acho que não é para mim, aí eu já não sei...

- Você está em dúvida?

- É...

- Você consegue ver vantagem?

- Se desse certo, né? Eu vejo, acho que a vantagem é de poder contar com o outro, né? De compartilhar... de dizer: "Ah, acho que você está ansiosa demais com isso, relaxa..."

- Mas você se sente bem do jeito que você está?

- Não, não tão bem, porque não consigo decidir se eu quero ou não.

- Isso te incomoda?

- Incomoda. Por enquanto, incomoda, mas não a ponto de eu querer mudar, de dizer: "Olha, o negócio é o seguinte: vamos morar juntos, então? Vamos ver qual que é?” Não..., não sei. Por enquanto, não!

Portanto, podemos conceber que Isabella recebeu dos pais um modelo de um vínculo bom, e sabe da capacidade de um vínculo de poder ajudá-la em suas questões cotidianas, da capacidade de acolhimento que alguém pode ter. Reconhece a existência de uma alteridade interiormente subjetivada e a importância do outro. Ela não sente que se basta. Porém, é como se ela desconfiasse da permanência do outro e dela, da capacidade dela de estar com o outro, de ceder, de abrir mão de algo, porque ela sabe que um vínculo saudável exigiria isso dela, mas também, e principalmente, porque sente que, no fundo, agindo assim estaria abrindo mão de parte de si mesma? Vale lembrar que o vínculo amoroso se encontra na tentativa de equilibrar a afirmação de si e o reconhecimento do outro e, no paradoxo desse movimento, conceber o outro como separado de si é fundamental. É como se, para Isabella, o outro pudesse ser reconhecido como separado, mas ainda assim o vínculo fosse ameaçador do seu estado interno de equilíbrio emocional e de afirmação de si: "Eu consigo compreender o que o outro diz, mas dificilmente eu vou abrir mão do que eu penso, assim: 'Ah, não, você está certo!'. Se você está certo, o problema é seu! Porque eu tô certa!” 
Importante ressaltar que, apesar da dúvida surgida durante a entrevista, Isabella quis participar da mesma por dizer-se "solteira por opção". Como se ela suspeitasse que a entrevista seria um bom momento para repensar o assunto. Ela conta que nunca teve certeza do seu desejo de investir num vínculo amoroso compromissado com a intenção de permanecer nele, mas foi depois de um vínculo bastante "problemático", "o mais louco" que teve, que se percebeu menos disposta a isso. O namoro durou dois anos, entre idas e vindas, em razão de traições e desconfianças. Não entra em detalhes, mas confessa que nesse relacionamento aconteceram "milhões de coisas", incluindo ter ficado presa numa alfândega. Parece ter sido bem tumultuado este que foi o último, mais duradouro e intenso dos namoros, e pode ter partido daí a sua suspeita de que um vínculo, quando profundo, para ela será inevitavelmente muito conflituoso e a fará sofrer, envolvendo não só brigas, como traições. Será que é porque sabe que tem algo nela, algum desejo inconsciente, que a recolocará nessa situação? Alguma herança geracional que não pôde ser transformada, causando a sensação, inclusive na pesquisadora, de falhas nessa história? Ou seria somente a necessidade de colocar o outro e o vínculo à prova? Testar a disponibilidade do outro, para permanecer ao lado dela? De qualquer forma, podemos trabalhar com a conjectura de que as rupturas de lugar na infância a formaram cheia de dúvidas sobre a possibilidade de confiar na permanência e na estabilidade do ambiente e de sua subjetividade: ou seja, do outro e dela mesma.

Desse conglomerado, provavelmente nasceu o sentimento de descrença, quando pensa novamente em ter um vínculo. O "desapego" foi uma construção posterior, uma defesa narcísica. Hoje, ela está nesse vínculo há cerca de um ano com o moço que passa alguns dias na casa dela, mas sabe que tanto ela quanto ele têm outros relacionamentos esporádicos. Isso, aparentemente, não parece incomodá-la, mas relata que incomodaria, se tivesse acordado fidelidade.

- Quais são seus valores mais importantes?

- Ah... Acho que ser coerente com o que fala. Acho que o discurso é de todo mundo: ser honesto, respeitar... mas é importante ser o mais transparente possível. Então, eu tento observar isso no outro, se o comportamento é coerente com o discurso.

- E quando você nota pessoas que são assim, você se afasta?

- É, não brigo não! Eu me afasto...

Transferencialmente, é muito interessante essa passagem, porque a pergunta da pesquisadora veio de onde? Ela não estava no roteiro, mas estava provavelmente na leitura das entrelinhas de sua subjetividade: o desapego promove o afastamento, porque, se permanece num vínculo, sabe que sofrerá em função da intimidade, das desconfianças e dos conflitos. No vínculo estabelecido com a pesquisadora, a ausência de detalhes e 
aprofundamentos parece, então, representar a necessidade de construir uma zona de segurança afastada, num vínculo que, embora agradável, não envolvesse os riscos da profundidade.

Os conflitos a assolam de tempos em tempos, mas também é como se Isabella soubesse que sozinha tem a capacidade de se (re)organizar, porque assim como ela conta que o "desapego" a "formou", a capoeira foi a outra coisa que igualmente a "formou": "Nessa época, eu me envolvi com a capoeira também. Fiz dez anos de capoeira... capoeira foi uma coisa que... também me formou!". Embora tenha parado por um tempo, ela sempre fez e deu aulas de capoeira, um detalhe pequeno, aparentemente, mas que a formou. Como se, nesse costurar da própria vida, Isabella tivesse descoberto um aspecto sobre si mesma importante, que dá sentido e ritmo à vida. Como se, no contato com o corpo, ela conseguisse entrar em contato consigo mesma e, em parte, assegurar-se como um ser humano, dar moldes à sua identidade, à sua construção subjetiva sempre tão em pauta.

Para Isabella, estar sozinha tem a função de assegurar sua construção subjetiva, porque, no contato com o outro, no vínculo construído com o outro, fica dolorido demais o trabalho de transformação e sustentação constantes da pulsão e de si mesma. Ela não confia em si mesma, não confia no outro, na estabilidade e na permanência das coisas e dos vínculos. O processo de reconhecimento e de respeito do outro fica atropelado por suas próprias crenças, projeções, e ela encontra no vínculo justamente a reprodução de um modelo inconsciente construído na infância: marcado por conflitos, desconfianças, não reconhecimentos e, novamente, rupturas.

Dessa maneira, o processo natural de transformação psíquica que o vínculo impõe provoca nela a sensação, por meio do sentimento de desconfiança interna, de que o outro, no processo de trocas, lhe rouba algo precioso, próprio do que é ela, daquilo de que ela faz parte. Não sente que ganha nesse processo, sente que perde na troca. A hipótese que permeia o entendimento de Isabella é de duas desconfianças básicas: dela e do outro.

Ainda que tenha recebido como herança um modelo de vínculo que deu certo, é como se não conseguisse acreditar profundamente nisso. A confiança que viu no vínculo dos pais acha "muito difícil de ver por aî". Assim, mesmo que pareça ter introjetado bons objetos, é como se o mundo e sua história de vida tenham lhe mostrado o oposto, deixando-lhe a dúvida. Referindo-se às condições de existência de hoje em dia, ela relata...

Acho que tem algumas facilidades, acho que... É, tem facilidades. Acho que a modernidade traz um monte de coisas junto: tem o conforto, mas ao mesmo tempo traz junto a instabilidade das coisas e das pessoas, fica tudo meio pasteurizado, junto... 
A instabilidade das coisas, das pessoas, deixa tudo meio pasteurizado, junto? Entendemos que ela estava aludindo à dificuldade de se diferenciar num mundo instável. Justamente a de constituir uma identidade sólida? Uma identidade que ajudasse supor certa permanência e a ajudasse a planejar o futuro? Parece que sim. Parece que Isabella estava se referindo às falhas das "garantias metassociais" (Kaës, 2005b), sentido o plano sociocultural como meio "pasteurizado", indefinido, pouco estruturado, sem referências, o que não lhe possibilitou ainda se organizar com relação ao futuro, porque parece que mesmo o presente a deixa um pouco perdida. De qualquer forma, ela pretende...

- Terminar o TCC esse ano e terminar a faculdade. Mas eu morro de vontade de ir para o Mato Grosso do Sul, ficar lá uns três anos... Mas agora penso em concurso, pensei de fazer um curso na "Poli" de Engenharia Ambiental... Queria conseguir bolsa... E aí voltar a dançar, porque vou ter mais tempo na vida...

- Está em seus planos ter filhos?

- Acho que está nos meus planos uma hora querer ter, mas agora não quero, não.

Muito interessante essa resposta. Está em seus planos um dia querer ter. Como se o planejamento fosse o de mudar os seus desejos, e não o desejo de mudar os seus planos. Porque ela não deseja. Admira a história dos pais, a herança de um bom vínculo, aprecia a boa companhia, mas é como se o que tivesse lhe restado é, por enquanto, seguir os passos da mãe rumo à independência, já que a vida a formou com o desapego e, no caso dela, mais que independência financeira, independência afetiva.

Finalizando, podemos imaginar que a dúvida de Isabella é a de que se ela consegue se apropriar da herança recebida da construção de bons vínculos, ainda que de forma diferenciada, longe do modelo tradicional. Parece que tudo se passa como se as mudanças, os conflitos e as rupturas sofridas na infância e na vida adulta não a tivessem ajudado a se sentir segura para a construção de uma subjetividade estável e a se apropriar da herança psíquica. Restou-lhe, por enquanto, a necessidade de ser "desapegada". Ao ir embora, comenta que foi interessante a entrevista, porque lhe propiciou "repensar a vida... Vou embora agora $e$ pensando!"'. Embora tenha esta capacidade de elaboração, supomos que Isabella não consegue ainda ter a esperança da construção de um bom vínculo e, por isso, não investe, não cede e não abre mão do que tem: ela mesma. 


\section{Henrique}

Aparentemente simpático e com razoável disponibilidade para o outro, Henrique, aos seus 33 anos, assume com certa simplicidade que levar uma vida de solteiro é bem mais fácil. No decorrer da entrevista, foi possível perceber que se referia ao modo como sente que a vida de um casal pode ser mais custosa do que a vida de solteiro.

Henrique parece ser uma dessas pessoas que gasta horas com os amigos, na mesa de um bar, discutindo e conversando sobre tudo. A pesquisadora sentiu que estar com Henrique seria bastante agradável, não fosse sua necessidade quase imperiosa de provar sua sabedoria, de mostrar aos outros o valor de seus conhecimentos, de seus argumentos, procurando convencê-los. Se acaso the perguntassem se ele prefere ser feliz ou ter razão, iria responder que prefere ter razão, segundo o próprio. Estar com ele fez a pesquisadora se sentir um pouco cansada, porque sua presença tinha um peso característico, é como se nos dissesse: "Tudo o que tenho para lhe dizer é muito interessante, portanto, preste atenção, concorde comigo e goste do que tenho para te contar!". É quase uma imposição, mas uma imposição que pode resultar num choque de opiniões, dependendo da pessoa, o que para ele significa um convite para um embate de ideias.

Apesar de morar sozinho, é ainda muito ligado à família, não em função de encontros, mas subjetivamente falando. Aliás, ele mora sozinho, porque os pais foram morar no interior, um dos irmãos foi junto e o outro está casado. Ou seja, sobrou-lhe a casa. Contou bastante de como os irmãos eram, a personalidade de um e de outro, do que concordava e do que não concordava quanto ao comportamento deles, alongou-se também sobre os pais, que constituíam uma família com boas condições financeiras e que hoje não são mais. O tema da questão financeira, inclusive, é um dos que apareceu de tempos em tempos, na entrevista. Preocupou-se em dizer, por exemplo, que achava que nessa altura da vida não conseguiria mais ficar milionário, mas que, se casasse com uma mulher que ganhasse como ele, poderiam ser considerados como classe "A". Nesse contexto, ainda explicou para a pesquisadora as diversas formas que existem para se medir a condição social de alguém, demonstrando sua atenção pelo assunto.

Segundo ele, esse foi inclusive um dos motivos de não ter se casado (ou pelo qual se casaria com alguém?), após quatro anos de namoro. Afirma ter "beirado o casamento", mas reconsiderado a ideia, porque a dívida que assumiria o fez concluir que não valeria a pena:

Sei lá, tem um certo peso isso! Sei lá, assumir família, esposa, comprar coisas na Casas

Bahia, comprar casa, tirar do banco, né? Assumir dívidas, você pensa: meu Deus, eu nunca 
vou terminar de pagar isso! Uma festa que vai se exaurir e nunca vou terminar de pagar isso... mas, tudo bem, eu vou entrar, ela vai entrar, o pai dela vai entrar, tudo bem... Então, eu cheguei à seguinte conclusão: se você tiver apaixonado, você vai gastar o que não tem e o que não pode. Eu sou uma pessoa muito controlada financeiramente!

Parece que o que Henrique quis dizer, nesse trecho, é que não sentia que estava apaixonado pela moça a qual namorou por quatro anos, mas que, caso estivesse apaixonado, sente que seria capaz de se descontrolar financeiramente, desorganizar-se para assumir uma dívida que, com plena consciência, não faria. Inclusive porque assumir dívidas significa ter a capacidade de se responsabilizar por algo que se julga de valor, como ele mesmo salienta, o que para ele significa assumir um "peso". O peso, supomos, de dar prosseguimento ao legado familiar, diante da dívida que todos assumimos em relação ao grupo familiar. Algo em torno da impossibilidade de assumir essa dívida parece ter falado mais alto e o feito recuar. Até o modo como ele conta isso, dizendo ter "beirado o casamento", nos fez imaginá-lo assustado à margem de um rio, como se acidentalmente tivesse se deparado com um rio e quase caído nele. $\mathrm{E}$, diante desse quase trauma, tenha recuado, porque a sensação da pesquisadora ao entrevistá-lo era a de que, no fundo, ainda era um menino brincando na sala de casa, quebrando a louça da mãe, enquanto ele, na vida de hoje, se "esforça" por manter a desordem nas relações atuais, o que parece agradá-lo.

Quando eu era moleque... Moleque é uma coisa! Homem é uma coisa que não devia existir, é improvável a gente chegar até a fase adulta! Por algum motivo idiota. É uma coisa que pode ser genética, cultural... Então, a gente brigava para caramba, a gente se batia... eu sempre fui muito maior, tinha $1 \mathrm{~m}$ e 80 na oitava série... É uma coisa horrivel... Então, a gente brigava muito, meu irmão mais novo era da paz, mas ele explodia e o outro era o provocador... E minha casa sempre foi a casa da reunião da turma, tinha sempre seis meninos lá em casa e a sala de visita era proibida para a gente. E a gente quebrava tudo, tudo... mas a gente ficou bem diferente como adulto, um virou um "bonacha", o outro quer ser "pater familia", quer governar tudo, tomar decisão, é mais quadrado...

Não se orgulha nem do irmão que se tornou alguém que não sabe brigar pelo que quer, nem do que optou por ser um "pai de família", justamente o que pelos opostos revelam ser características de sua subjetividade. Ou seja, não é e não admira alguém que não saiba se impor ou que assuma a responsabilidade pelo grupo familiar. A sensação que passa é a de que se irrita com os irmãos, porque precisava que eles ainda estivessem ao seu lado, feito crianças, sendo somente irmãos e continuassem brigando/brincando com ele. Só sobrou ele na casa da reunião da turma, como aquele que ainda contempla e revive intensamente o passado.

O modo como se vincula com o mundo, como se realmente estivesse brincando, ou inventando discussões para sobreviver, nos fez supor que o impediu que se formasse pelos cursos das faculdades pelas quais passou, restando-lhe a formação de tecnólogo. 
Eu tenho algumas ideias do que eu posso ter na minha vida... Eu passei da fase de ficar milionário... eu agora estou em busca do segundo milhão, porque o primeiro não rolou... Eu acabei me formando muito tarde, porque larguei dois cursos da faculdade, né? Eu comecei Química, fiz Física, não gostei... Passei um ano fazendo cursos diversos, História da Ciência, Matemática Financeira... Aí tirei mais seis meses de férias, aí entrei na FATEC e levei a faculdade nas coxas e me formei... Quando desencanei de testar os conhecimentos e questionar, eu me formei... Eu penso bolinhas, mas o que o cara quer que eu escreva? Azul? Então, tá bom: azul. Não quero mais raciocinar o que é mais certo ou errado... E aí eu parti para o setor público, eu sou empregado público...

Supomos “invenções”, não num sentido pejorativo, porque ele é bastante inteligente: é muito provável que suas digressões na faculdade estivessem matematicamente corretas, mas não deviam deixar de ser digressões, o que fez durante toda a entrevista. A pesquisadora perguntava "bolinhas" e ele respondia "azul", para ter-se uma ideia do que provavelmente também ocorria na faculdade. Por exemplo, foi perguntando sobre o porquê sente que a vida de solteiro é mais fácil que ele acabou dando a resposta transcrita acima. Não que fugisse completamente do assunto, mas as respostas não eram muito lógicas; num movimento quase de associação-livre, acabou explicando que é porque, na verdade, o dinheiro para ele é algo importante.

A entrevista foi cansativa, pois ele parecia necessitar de muita atenção, da valorização de suas histórias e por ser detalhista. Contando sobre sua personalidade, ele assume ser uma pessoa metódica e irritada: não vai se importar com a bagunça, se esta estiver de acordo com os princípios de todos, mas, se acaso alguém não cumprir com o combinado, isso o deixará muito irritado. Precisa das normas para se organizar, é bastante preso aos princípios, como se precisasse de manuais para entender as pessoas, ou como se necessitasse de regras claras para sua organização psíquica.

(...) acho que eu, que eu percebo bem as pessoas, isso é uma vantagem minha, mas eu não lido bem com elas, eu me irrito muito rapidamente com as pessoas. Em algum momento, as pessoas têm o mesmo tipo de leitura que eu tenho, mas aí o cara vê uma coisa que eu penso: "Ai, meu Deus!". E aí é que entra: eu prefiro ter razão... O cara tá falando uma pá de besteira, e às vezes eu não consigo deixar para lá..., principalmente quando eu gosto!

Ele parece nos dar uma noção de sua maneira principal de se vincular: não suporta a diferença de opiniões, de argumentos, de pensamentos e, sobretudo se ele gosta do outro, em algum momento, este terá que acatar os seus argumentos como corretos. Ele precisa que o outro se adapte a ele, demonstrando um tipo de estruturação narcísica em que somente ele está com a razão. Henrique parece apresentar certa "inflexibilidade psíquica", isto é, certa rigidez de pensamento e uma incapacidade de ter processos elaborativos que deem conta de aspectos 
diferentes ou mesmo inesperados da realidade, incluindo a capacidade de representar a falta e de lidar com a frustração.

Entendemos que é no processo de reconhecimento do outro, de conceber a diferenciação do outro, de aceitar pensamentos divergentes ao seu, que algo se complica para Henrique. Quando diz que "percebe bem as pessoas", deve estar se referindo ao modo como percebe a existência de pensamentos divergentes ao seu, não no sentido da empatia, porque aquilo que diverge muito o incomoda. E tudo se passa como se buscasse a cada impasse desse tipo unir suas forças para conseguir convencer aquele de que gosta de que ele está certo, formando um todo com o outro, num movimento que procura anular os conflitos, mas também o outro, fusionando-se com ele. O paradoxo necessário do vínculo, entre a afirmação de si e o reconhecimento do outro, fica comprometido, porque parece pretender conquistar essa afirmação de si pelo controle e dominação do outro.

$\mathrm{Na}$ análise desse caso, fomos compreendendo que Henrique propõe um estado fusional ao vínculo, de indiferenciação, pela anulação dos conflitos. Nenhum dos "quatro R" (Eiguer, 2008) que sustentariam a existência de um vínculo saudável parece ter lugar em Henrique. As opiniões alheias não fazem ressonância nele, e o estado de indiferenciação que procura construir reflete características de uma formação narcísica onipotente que busca a ilusão de viver em uma completude.

Aos 18 anos, na faculdade, iniciou seu primeiro namoro, segundo ele, muito tardiamente, porque sua mãe sempre foi muito protetora e não deixava os filhos saírem da "bolha". Foi a menina quem se interessou por ele, porque salienta que jamais tomaria partido naquela época, e namorou-a durante quase toda a faculdade de uma forma, imaginamos, muito conturbada.

Outra coisa que me marcou foi o final desse relacionamento, porque eu não esperava: você acha que está fazendo tudo certo, aí depois você se toca do que estava fazendo. Quando eu tive meu segundo relacionamento, eu percebi tudo que eu tava fazendo de errado no primeiro. Eu era extremamente ciumento, e isso eu aprendi com os meus pais... Eles são doentiamente ciumentos! Hoje, eu percebo isso, na época achava que era absolutamente normal... E eu passava muito tempo com ela, eu levava ela à noite para casa, só não pegava ela de manhã... Em nenhum outro relacionamento eu fiquei tão junto!

Nessa passagem, Henrique revela o aspecto fusional que o seu primeiro namoro teve, o seu ciúme exacerbado apontando para uma insegurança grande com relação a si mesmo e a necessidade do outro como suporte psíquico. Além disso, observamos o caráter de herança que esse modo de vinculação carrega. Do casamento dos pais, conta que talvez "o ciúme doentio tenha ajudado a equilibrar as coisas", as diferenças quase opostas, supomos, porque 
a mãe, enquanto filha de militar, queria ter sido freira e o pai, adepto ao movimento de esquerda, "antirreligioso, antitudo!" passou a faculdade toda reivindicando. Ele parece ter herdado um modelo no qual a vinculação se dá prioritariamente pelos opostos que se mantêm unidos às custas de embates e de uma paixão por características que não se tem e que se busca/admira inconscientemente no outro. Inconscientemente, porque, numa vinculação de tipo fusional, não há espaço para o aparecimento das diferenças diante da insegurança que elas geram em cada membro do casal e da manutenção do mesmo. Contudo, não sabemos se ele também recebeu isso geracionalmente, porém, no caso de Henrique, nesse movimento, há ainda a presença de um funcionamento psíquico em que, caso aquele que admiro se convença de meus argumentos, eu me enriqueço perante mim mesmo, num tipo de batalha onde a conquista está em receber o reconhecimento do outro, sem reconhecê-lo. É na ordem desse tipo de embate vincular que Henrique parece ter-se constituído subjetivamente.

Foi marcante a forma como se orgulha das histórias do pai. Comenta que o pai às vezes se lembra de sua época de faculdade e conta para os filhos as aventuras e conflitos que viveu, o que parece deixá-lo bastante orgulhoso do pai, mostrando estar bastante identificado com ele, nesse aspecto de armar conflitos. Sabe que os pais brigavam, mas ele não via, porque as crianças eram colocadas no quarto nesses momentos. Julga boa a educação que teve, visto que, apesar das discordâncias, nenhum deles ousava tirar a autoridade do outro. Nesse âmbito, parece que o contrato narcísico e os mecanismos de identificação estão atuantes e preservados. Se tivesse, contudo, que dar prosseguimento aos valores que recebeu dos pais, comenta que iria se esforçar um pouco mais do que o pai para dar liberdade aos filhos, pois, apesar dos "cortes" do pai, a mãe os guardou dentro da "bolha". Uma liberdade que, no fundo, ele mesmo não soube ou não pôde conquistar, supomos, em face de uma falta de segurança que somente o vínculo amoroso parece ter-lhe dado por muitos anos.

Trata-se, portanto, de um processo de construção subjetiva em que a insegurança é negada no aparente exercício de um grande jogo: Henrique, através de num movimento de defesa, brinca com o que não suporta, deprecia o que o angustia. Ele não sabe lidar com a diferença, com a alteridade, ela o assusta, deixando-o inseguro. Assim, desorganiza-se e necessita convencer o outro para sentir-se seguro de sua integridade psíquica, porque precisa do reconhecimento do outro a fim de se assegurar de si mesmo. Baseando-se em Benjamin (1988), Eiguer (2008) ressalta que, no processo de reconhecimento, à medida que o sujeito precisa da preciosa certeza que advém do outro de ser ele mesmo para poder existir, pode procurar dominá-lo, quando sente que o outro resiste. No caso de Henrique, a pesquisadora sentiu o quanto pode ser difícil estar com ele, caso não se concorde com o que ele pensa: é 
mesmo uma imposição subjetiva, como se procurasse aniquilar o ego alheio, para sustentar o próprio. Ainda que diga que tenha percebido o "erro" no primeiro vínculo amoroso, por ser muito ciumento, o mecanismo de procurar transformar a dupla em uma unicidade ainda permanece pelas vias de alcançar ser reconhecido pelo outro, sem reconhecê-lo.

Como se hoje se arrependesse de não ter vivido mais intensamente a época da adolescência, acha que, por ter sido o filho mais velho, sofreu mais com a falta de liberdade imposta pela mãe. Assume que, após a separação do primeiro namoro, passou dois anos sozinho, vivendo aos 20 anos de idade "essa coisa depressiva, chata, dark, que todo mundo tem na vida", sentindo-se velho demais para isso. Depois dessa fase, diz praticamente ter emendado um relacionamento no outro, cada um durando, em média, dois anos, até o último, quando quase se casou - e então decidiu que queria ficar solteiro. Aparentemente, Henrique descobriu aos 30 anos que podia ficar sozinho, sem a necessidade psíquica de uma namorada para ajudá-lo a sustentar-se, sem a necessidade de um ego auxiliar. O modo como essa passagem se deu não sabemos, mas parece que levou um susto tão grande, por ter "beirado o casamento", que resolveu passar um período sozinho e, nesse tempo, descobriu inclusive que assim poderia ficar. E hoje é como se buscasse recuperar o que sente que perdeu na adolescência: a despreocupação em relação à vida e ao futuro, as festas, as desordens e as descobertas, num tipo de vida um pouco sem rumo.

- (...) e eu, eu tô levando a vida. Na verdade, não sei se estou no caminho certo, mas como eu tô vivo, não tô morto, tenho que viver...

- Você pensa nisso às vezes?

- Penso, mas não sei... Eu não vou ser o que meus pais foram e nem o que meus irmãos querem... Eu tenho o meu caminho, mas que eu não defini ainda... O que eu quero ser eu não sei direito ainda...

Temos aqui uma clara interferência das condições contemporâneas de existência no estabelecimento do "contrato narcísico" (Aulagnier, 1979), quando perpassado pela ampla opção de escolhas (Kaës, 2005b). Isso o faz não se identificar com alguns dos valores cultivados pelos pais e interfere no processo de transmissão do legado geracional, porém, ao mesmo tempo, permite-lhe repensar a vida num momento em que descobriu a possibilidade de ficar sozinho, para que possa elaborar melhor para onde ele pretende seguir, ainda que não saiba muito bem por quais caminhos trilhar, numa postura um tanto quanto desiludida. Embora pareça estar um pouco descrente com relação ao seu futuro, compreendemos que se trata de um posicionamento interessante, porque é como se, ao "beirar o casamento", tivesse se dado conta de que não tinha condições para compartilhar uma vida onde tivesse que se 
responsabilizar pelo outro, e respeitado a opção de parar para repensar suas escolhas. Falando sobre as desvantagens de um relacionamento estável, ele assume que uma delas está

(...) em que mesmo se você não quiser, você vai ter que estar ali. Tipo assim, hoje eu queria estar sozinho... mas "amigo, hoje é sábado à noite! E você vai sair com ela, porque ela quer ir no cinema, porque ela quer... comprar um cachorro, e você vai fazer, porque é o protótipo..." Eu tenho que te oferecer isso porque você vai me oferecer quando eu quiser dividir também...

- Isso te incomoda?

- Não. É uma desvantagem. É uma moeda. Você só pega a cara da moeda, se você pegar a coroa. Entendeu? É o pacote. Ou você quer, ou você não quer...

E ele, por enquanto, não quer. Parece que Henrique concebe o vínculo compromissado como um tipo de contrato em que fazer pelo outro é cansativo, incômodo. O fenômeno do "modelo tecnológico" e sua constituição narcísica sustentam esse tipo compreensão da alteridade e do vínculo compromissado. Prefere ter vínculos efêmeros, porque não precisará assinar esse tipo de contrato em que é necessário dar para receber, porque, no seu caso, dar é como doar parte de si. Ele entende que perde, na troca. Acreditamos que é como se Henrique tivesse se dado conta de que se responsabilizar pelo outro, reconhecê-lo em suas necessidades e vontades, significa dividir "o espaço onde o eu pode advir" (Aulagnier, 1979). Nesse âmbito, também compreendemos melhor sua dificuldade em assumir dívidas, ainda que divididas!

Minha mãe estressa muito mais, ela diz que eu devia dar netos para ela... Não, para fazer netos, se você quiser a gente dá um jeito... A gente dá um jeito, tem gente para isso disponível no mercado, mas criar já é outra coisa! Eu teria que ganhar duas vezes o que eu ganho, porque tem um custo envolvido nisso que não é pequeno, para sustentar uma família... é pesado. E do mesmo jeito que você tem que dividir tarefas num relacionamento, você tem que dividir muito seriamente as tarefas, quando se trata de uma criança. Uma criança é uma responsabilidade muito séria. É uma vida que você não vai se desfazer dela.

Ao mesmo tempo em que revela ter consciência sobre o caráter de responsabilidade que representa ter uma família, é a mesma consciência que o faz se afastar dessa possibilidade. Como se as dívidas, mesmo que divididas, fossem pesadas demais para ele aguentar. Nessa altura, podemos pensar na constituição de um mosaico para o porquê desse incômodo.

Primeiramente, podemos entender que Henrique parece ter entrado numa nova fase, na qual, mais consolidado psiquicamente, deu-se conta de que pode ficar sozinho, sem namorar alguém. A despeito de podermos perceber um custo grande, um peso por sustentar-se sozinho psiquicamente - de onde advém a sensação de cansaço da pesquisadora de estar com ele, porque é como se apoiasse no outro, como se precisasse dos recursos do outro para se estabelecer -, ele hoje não busca mais por uma colagem, por vínculos amorosos próximos da 
indiferenciação. Ainda procura o reconhecimento do outro por imposição, mas sozinho. Por exemplo, é muito curiosa a maneira como define "intimidade":

Intimidade é uma questão totalmente diferente. Acho que eu tenho intimidade com uma pessoa que conheci ontem e não tenho com pessoas que conheço há vinte anos. Intimidade tem muito a ver com o que a pessoa te passa, o que a pessoa tem a oferecer para a pessoa naquela hora e o que você tem a oferecer... Então, o que você tem para mim hoje? Depende muito também do momento. Intimidade é uma coisa de momento, você pode ficar muito íntimo de uma pessoa numa viagem, por exemplo, porque você tem que criar aquela relação naquela hora. Dois dias depois... porque, por mais que você tenha ficado muito íntimo de uma pessoa numa viagem, você não vai mudar sua vida para continuar a tê-la. Então, intimidade é o que você tem para hoje... Diferente da confiança: confiança é construída, confiança, respeito, até admiração é construído.

Verificamos que se sente íntimo de alguém, quando se percebe em consonância com essa pessoa, o acordo entre eles, seja porque esse outro se submete aos seus argumentos e pensamentos, seja porque encontrou alguém que realmente concorda com ele, num vínculo que envolva grande afinidade e um contato próximo sem conflitos. Nessa passagem, Henrique relata compactuar com a fluidez com que podem ser formados os vínculos, atualmente, além da facilidade com que são desfeitos, uma vez que "você não vai mudar sua vida para continuar" a manter o vínculo.

Em segundo lugar, sobressai-se o aspecto financeiro. Há algo que foi perdido na bagagem familiar de Henrique. Conta que pertencia a uma família de classe média alta, quase rica, a qual veio a perder muito dinheiro, sem dizer como. Conta também que poderia estar ganhando mais dinheiro, mas que hoje gosta do seu emprego. Para se casar, precisaria ganhar mais que o dobro, ou seja, podemos inferir que, no seu caso, ganhar mais dinheiro é primordial para pagar a dívida geracional. Não que a dívida geracional devesse ser paga com dinheiro, porém, talvez seja primordialmente com o resgate do dinheiro perdido que ele tenha se compromissado, em detrimento de se casar e ter filhos, dando continuidade ao legado familiar. Sente, talvez, que ele foi um peso para os pais? Que perderam o dinheiro por sua causa? Ou que deve isso a eles, sendo ele o filho mais velho? Em sinal de gratidão?

Parte da herança está perdida e ele sente essa parte concreta como subjetiva, como parte dele mesmo. Hoje em dia, já sabe que não vai ser mais milionário, mas ainda almeja melhores condições de vida, e a presença de uma mulher em sua vida representa perder mais dinheiro do que ganhar, a menos que ela fosse rica, como ele mesmo salienta. De qualquer forma, temos aqui o peso de uma herança, que não sabemos se foi imposta pelos pais. $\mathrm{O}$ que sabemos é que o pai se tornou comerciante, embora tenha feito faculdade e pós-graduação, demonstrando uma preocupação, supomos, com a questão financeira. Henrique, identificado com o pai como é, provavelmente pensa em seguir os mesmos princípios. Mas não apenas. A 
sensação também é a de que como se, por meio do dinheiro, fosse capaz de recuperar algo perdido nele mesmo. Imaginamos que simbolicamente o dinheiro é visto como parte de si, como recurso psíquico e, por isso, se casar com uma mulher rica ajudaria: porque, na sua fantasia, ela teria recursos para ajudá-lo a se estruturar (psiquicamente) e a resgatar a herança geracional.

Além disso, na construção desse mito individual, podemos detectar uma consonância com os mitos sociais de uma sociedade consumista, que acredita poder conquistar felicidade e segurança através do dinheiro e do poder de aquisição. Henrique ainda apresenta outras características de uma subjetividade em consonância com as condições de existência contemporânea: a concepção de uma alteridade incômoda, os ideais de êxito, de controle do outro, de independência, e a necessidade de aproveitar a vida longe de um vínculo estável e estruturado, todos ligados com uma estruturação narcísica, também esta como efeito das condições de vida socioculturais. Ou seja, sua "inflexibilidade psíquica", dificuldades de simbolização, elaboração, representação da falta e em lidar com a frustração no processo de separação em parte sustentam-se em sua constituição subjetiva, em função de falhas das "garantias metassociais".

Em acréscimo, é preciso considerar uma herança geracional marcada por uma doença importante, o câncer, que já atingiu pai e mãe, além de ter sido a causa da morte de muitos dos familiares, incluindo seus padrinhos. Malgrado tenha dado pouca importância ao fato, porque diz se cuidar bem, essa pouca importância é compatível com o perfil que estamos desenhando: de alguém que não consegue lidar com o que incomoda. Somando esse fato ao de que sente que sua família tinha melhores condições financeiras na infância e pelo modo alegre como contou das brigas entre os irmãos, naquela época, podemos conceber que, para Henrique, a infância se tornou idealizada, diante dos problemas da vida adulta, da doença dos pais e da falta de dinheiro. Parece que hoje ele se sente empobrecido perante seu passado. Henrique aparenta ser forte e cheio de convicções, quando lá no fundo uma criança frágil ainda brinca de faz-de-conta de que tudo que machuca não existe. Uma fragilidade narcísica que procura se alimentar de afirmação de si quase "roubada" e de dinheiro para ficar mais forte.

Hipotetizamos que, se ele tivesse nascido em outra época, talvez houvesse se casado com a moça que namorou por quatro anos. A sociedade atual tornou legítimas opções que antigamente seriam mal vistas. De certa maneira, possibilita uma abertura e a singularidade na composição de um caminho, no tempo e do tempo que se precisar, ao mesmo tempo em que retirou as bases para que essa estruturação pudesse ocorrer de forma mais simples e 
consolidada. Ficam questões, contudo, por onde se caminhar, no caso de Henrique, cujo único projeto que tem para o futuro é, na verdade, um desejo de um dia trabalhar numa empresa que julga importante em seu ramo.

$\mathrm{Na}$ leitura desse caso, por vezes apareceu a dificuldade de Henrique de diferenciar-se do outro e, portanto, de representar a falta simbolicamente. Finalizando, podemos pensar que falhas nos processos de simbolização podem tê-lo levado a misturar o real com o simbólico dentro de si, processo em que o dinheiro, a perda do dinheiro dos pais, somou-se à suas inseguranças internas, num tipo de funcionamento psíquico em que se tornou prioritário recuperar o dinheiro perdido, para se recuperar psiquicamente. De fato, quando conta da família, fala como se fosse um todo estendido. Um movimento igualmente sustentado por nossa sociedade, que, além dos ideais consumistas e de sucesso financeiro, realmente promove no indivíduo, como ele mesmo disse, a sensação de que precisa ganhar duas vezes mais, para dar pelo menos aos filhos o mesmo padrão de vida que teve. Parece que é nesse ponto que Henrique ficou "enroscado". Isto é, evita ter um vínculo amoroso compromissado, porque se deu conta de que pode vir a envolver um casamento, e um casamento, filhos. Ao mesmo tempo em que parece que deseja dar continuidade ao legado familiar, não se percebe nele um desejo em aceitar a responsabilidade por assumir o grupo familiar, mas o contrário. A nosso ver, Henrique precisaria se sentir mais seguro psiquicamente, para se responsabilizar pelos membros de sua possível família. Por enquanto, resta a fantasia de que resgatar o dinheiro perdido pode trazer de volta o conforto psíquico da infância idealizada e perdida, substituindo qualquer outro projeto.

\section{Tatiana}

Como se tivesse acabado de cair do ninho e descoberto a possibilidade de voar, Tatiana assume que ter liberdade na vida é algo essencial para ela. Ela afirma que só conseguiu dar sentido à vida depois que saiu de casa.

Foi após os seus 23 anos, depois de ter passado num concurso de uma empresa estatal e tendo ido morar no Rio de Janeiro, que ela sente que sua vida ganhou algum ar de importância. Antes disso, não se lembra de nada de marcante, embora, para nós, seja importante a lembrança de que os pais trabalhavam muito e de que "ela e a irmã foram criadas por babás", porque "por um bom tempo a babá era mais presente que mãe e pai”. 
Considera que mudar-se de Santa Catarina foi sua primeira e grande mudança na vida, deixando família e namorado para trás.

(...) foi uma experiência diferente. E daí eu comecei a viajar muito a trabalho. Então, minha vida mudou bastante, quando eu comecei a descobrir o resto do Brasil. Porque até então meu Brasil se resumia a Santa Catarina, Rio Grande do Sul e Paraná, nem São Paulo eu conhecia! Então, minhas férias também mudaram... porque, como eu já estava viajando pelo Brasil inteiro, eu comecei a viajar pelo mundo. Então, desde 2005, eu tenho pelo menos uma viagem programada, grande assim, todo ano.

Apesar de ter realmente parecido ganhar asas, a distância de casa não foi vivida como prazerosa. O namoro terminou e Tatiana sentia muita falta da casa dos pais, voltando para lá sempre que podia. Aos 31 anos, conta com certo pesar que demorou muito tempo para entender que lá não era mais o seu lugar.

- Ah, porque eu saí de casa meio sem querer... Assim, eu queria sair de casa, mas com alguma coisa certa! Aí eu saí, porque eu passei no concurso... E todo fim de semana eu dizia que ia para casa, e ir para casa era ir para Santa Catarina. E por muito tempo eu acreditei que, se eu voltasse para Santa Catarina, eu ia voltar a morar com eles [pais]! Mas assim, aí minha mãe foi me dizendo sobre comprar apartamento... e hoje a ficha já caiu assim, se eu voltar para lá não vou morar com eles.

- Mas você gostaria?

- Hoje não mais. Nos primeiros cinco anos fora de casa, eu ainda pensava em voltar, mas hoje eu sinto que eles não querem mais, eles já têm o espaço deles...

Interessante notarmos que ela diz que saiu de casa "meio sem querer", como se uma parte dela não quisesse ou não estivesse totalmente pronta, ainda. O passarinho até voou quando caiu do ninho, mas com algum preço? Perdeu algo? Ela explica que não voltaria a morar com os pais, porque sente que eles não a querem mais por perto e não por um desejo seu. Conta que, após sua saída de casa, muita coisa mudou no casamento deles, pois passaram a ficar mais tempo juntos. Como a irmã saíra mais cedo que ela, tendo ido estudar fora na graduação, ela foi a última a sair, mesmo mais velha, deixando um espaço na casa que parece ter sido apropriado pelos pais, como uma sensação de maior liberdade para o enamoramento. Tatiana se lembra de que os pais nunca foram de demonstrar carinho um pelo outro, o que ela sempre achou muito estranho, chegando a dizer que não os considerava como um casal. Hoje em dia, tudo é muito diferente: aproveitam o tempo juntos para se divertirem, porque imaginamos que conseguiram assumir com mais tranquilidade a própria existência como casal conjugal e a sexualidade.

(...) mas eu via que os pais dos meus amigos se despediam com um selinho, sabe? Meus pais nunca tiveram isso, eles mal se encostavam... E quando eu saí de casa para ir para o Rio de Janeiro, eu vi que eles começaram a namorar: começaram a dançar, a ir para o cinema... porque antes eles iam para levar a gente... Porque antes não existia sair só os dois, não tinha sentido. E... acho que é isso: quando eu saí de casa, eu notei, me parece que agora eles têm uma vida de casal mesmo. 
É como se Tatiana sentisse que incomodava os pais ou que os incomodaria, voltando para casa, porque realmente tudo se passa como se a presença dos filhos, para esse casal, significassem assumir prioritariamente o lugar de pais, de casal parental, em detrimento ao de casal conjugal. Parece que algo em torno da ordem da sexualidade tivesse que ser evitada, diante dos filhos. A hipótese de Tatiana é a de que não tiveram tempo de namorar, como se não tivessem tido tempo, supomos, de se conhecerem em função da pressa, das exigências da vida - uma vida bastante preenchida por trabalho e pelo cuidado com os filhos. Ela conta que hoje em dia sabe que o próprio casamento dos pais passou por questionamentos, mas que, na época, não desconfiou disso. Dado o distanciamento natural entre os pais e com relação às filhas? Aparentemente se sobressaía o vínculo parental e o posicionamento de pais que estavam mais preocupados em dar boa condição de vida às filhas, sem preocupá-las com nada. Hoje, ela sabe inclusive que, num certo momento da vida, passaram por dificuldades financeiras, mas que ela também nunca desconfiou.

$O$ casamento [dos pais] foi feito meio às pressas, porque a empresa que meu pai trabalhava pagou um curso para ele nos Estados Unidos e aí, naquela época, os caras iam casados, para fazer a comida, e ele ficou desesperado, porque não tinha ninguém... Aí pediu minha mãe em casamento e foram meio rápido... Aí, quando eles chegaram no Brasil, já me tiveram... Então, não sei se eles puderam ter uma vida legal como casal...

Nada romântica a maneira como ela concebe o planejamento de casamento dos pais. Tatiana conta, nas entrelinhas, algo de uma sensibilidade, de uma tristeza, desenvolvida pela falta de algo. É isso que a pesquisadora sentiu. Parece que está ressentida pela falta de carinho não só entre os pais, mas também entre pais e filhas. A despeito de se orgulhar muito dos pais, das conquistas que obtiveram na vida, da melhoria da condição social, durante toda a entrevista, a pesquisadora sentiu um ar de ressentimento com respeito a eles, um sentimento de ter sido abandonada.

A minha mãe, para as filhas delas, ela falava assim: "Ah, o importante é ter saúde!". Cada coisa mais agradável que ela podia falar! Quando eu estava estudando piano, era só barulho, sabe? "Ah, eu não aguento mais esse barulho! Para com esse barulho!". E aí chegava para minhas amigas e comentava, uma vez até escutei: " $\mathrm{A} h$, você viu como a Tatiana está tocando bem?". Sabe, nunca falaram para mim... Então assim, sabe, falta incentivo... [ela usa o verbo no presente], eu não sei como minha irmã e eu nunca tivemos problema de autoestima! (...) Eu acho estranho... Não tinha muita cobrança, não... Eles nem sabiam quando a escola entregava o boletim! Não sabiam quando a gente ia ter prova, mas a gente ia passando, ia bem, eles nem se preocupavam...

Antes tivesse tido alguma cobrança, não é Tatiana? Porque provavelmente assim ela se sentiria mais cuidada, mais querida. Depois da faculdade de publicidade, profissão que exerce atualmente, fez faculdade de música e diz que tocava piano cinco horas por dia, o que parecia 
irritar a mãe. Tatiana nos fez pensar em pais muito práticos, muito objetivos, muito preocupados em oferecer aos filhos o que não tiveram, provavelmente, e pouco preocupados pela forma como Tatiana sentia falta de um vínculo mais próximo, mais afetivo. Pais que provavelmente supõem o desenvolvimento natural dos filhos como se fosse por obrigação deles, por gratidão, em função do esforço que fizeram. Um tipo de vinculação pais-filhos que parece ter sido herdado pelos pais de Tatiana de seus próprios pais, partindo do pressuposto de que não se dá o que não se recebeu, seja porque o que não foi recebido não se conjectura a existência, seja porque não se sabe como fazer, porque não supunham a necessidade, ou ainda porque se ressentiam igualmente pelo modo como foram tratados pelos pais e, por isso mesmo, consciente ou inconscientemente, esse cuidado mais próximo foi negado.

Inferimos disso um mecanismo de identificação com os pais que contempla um misto de sentimentos conflituosos, entre o orgulho, a admiração por tudo o que os pais foram capazes de construir na vida e o ressentimento pela falta de um carinho, de um olhar, do reconhecimento. Ela ressalta que os pais sempre trabalharam muito e que os dois passaram em concurso do Estado. Da mesma maneira, pela via da identificação positiva com os pais, ela também passou num concurso do qual muito se orgulha e a faz se sentir bastante satisfeita, profissionalmente, como se isso bastasse para se sentir satisfeita com a própria vida. Lembrando-nos do mito "do homem e da mulher de êxito", do mito da "independência", Tatiana relata...

Bom, a profissão está ligada à minha autoestima, à minha confiança e ao meu prazer de viver! Hoje, eu estou lá porque eu gosto. Eu não tô lá há sete anos, porque eu passei no concurso e me acomodei! Até porque eu não sossego. Então, quando eu vi que eu estava começando a ficar acomodada no meu emprego no Rio de Janeiro, eu comecei a olhar para os lados e, como é uma empresa estatal, antes da demissão você pensa em transferência. Aí apareceu São Paulo. Agora já estou feliz de novo...

Ela mesma responde por que não tem problema de autoestima: ainda pela via da identificação positiva com os pais, parece ter associado parte de sua autoestima ao trabalho, às conquistas nesse âmbito. Após ter morado quatro anos no Rio de Janeiro, veio para São Paulo, onde se sente muito bem, embora não queira ficar nesta cidade para sempre. Para ela, a ideia de "criar raízes" não agrada, não se sente bem nem com a ideia de comprar um apartamento, no que a mãe insiste. Na passagem acima, ainda podemos perceber que esse "não sossego", que pode ser entendido como o seu desejo pelo novo, pelas descobertas, possui um movimento psíquico subjacente de se entediar pelo conhecido. Ainda pretende morar em muitas outras cidades, mesmo que isso não agrade os pais. Tatiana sente que está desapontando os pais, por não ter-se casado ainda, mas isso ela realmente não pretende fazer. 
A monogamia é uma coisa estranha para mim, você acordar e ver todo dia a mesma cara é complicado! Porque não é que você não goste da pessoa, mas é que às vezes você quer simplesmente acordar e não ver ninguém, ou sei lá, quer ver outra pessoa... e como para mim ser sincero, ser honesto é muito importante, eu me sinto mal em trair... Quando eu estou numa fase de sair, eu não prometo nada para ninguém, deixo bem claro que estou saindo com outras pessoas e digo que devia fazer o mesmo.

Tatiana tem uma subjetividade que aponta para um funcionamento psíquico parecido com o de um libertino. O tom de sinceridade e o desinteresse pela intimidade psicológica alheia, associados ao tédio que parece sentir pela constância, são elementos fundamentais de uma construção desse tipo. Mas não apenas. Porque tem algo em torno do cuidado do outro que muito a incomoda. Do cuidado que sente que não teve? $\mathrm{E}$, nesse sentido, não acha justo dar aos outros?

Ela conta que seu último relacionamento muito a marcou, porque ele era um pouco depressivo, tinha dificuldades de fazer amigos e ela precisava "agenciá-lo" a todo o momento. Quando saíam com os amigos, ela necessitava trabalhar muito para que isso acontecesse, porque ele não queria que fossem só os dois, mas não a ajudava a convidar os amigos, tornando para ela cada simples encontro um verdadeiro "evento". Porém, foi principalmente após uma viagem que fizeram juntos que ela se deu conta de que não tinha mais condições de ficar com ele, porque ele ficou doente e, além de terem "perdido a viagem", ela praticamente se transformou numa "enfermeira", o que a fez repensar alguns valores herdados dos pais.

(...) antes do meu ex-namorado, achava que... beleza, que era a lei natural das coisas, que uma hora você encontra a pessoa e vão morar junto, e casa e tem filhos, constrói uma vida a dois. Agora, acho que não. É, mas hoje acho que o maior problema foi meu... Então, assim, eu vejo que tinha muita coisa lá que era eu, não ele. Para mim, é muito importante eu me sentir livre, sabe? Liberdade, assim, e com ele eu não tava me sentido livre. Coisinhas pequenas, assim, horários diferentes de trabalho: ele chegava mais cedo e cobrava também isso de mim, e aí eu parei de ir na academia... que ia depois do trabalho, aí tem todas as consequências de parar de fazer exercício, né? Ele queria sair, ir para barzinho, mas não queria ir só nós dois, sempre só nós dois! Mas ele não conseguiu fazer amizade com os meninos com quem eu andava, não rolou. Ele conversava mais com as minhas amigas, mas minhas amigas também tinham os respectivos, aí ficava difícil. Aí cada vez que a gente ia fazer uma coisa simples, um happy hour, virava um evento, porque ai eu telefonava para um, para outro para combinar horário, o dia tudo... eu fui ficando estressada. Eu tinha que arrumar a vida social dele, tudo! Então, eu descobri que a minha liberdade é mais importante!

Incomoda Tatiana ter que se responsabilizar pelo outro, como se isso fosse incompatível com os seus interesses pessoais. Nesse namoro, em específico, isso deve ter ficado bem mais marcante, fazendo-a se dar conta de que não é o que quer para a vida, fazendo-a repensar a herança recebida. A impressão que ela passou foi a de que, uma vez ao lado de uma pessoa, sente como se precisasse cuidar mais da pessoa do que dela, das vontades 
da pessoa, abrindo mão de si, tornando o vínculo muito custoso para ela, porque seus interesses pessoais parecem ser prioridade.

Todavia, levando em consideração o ressentimento que tem pelos pais, o que supomos, nesse caso, é que o processo de reconhecimento do outro está atravessado por mecanismos projetivos, fazendo-a sentir doloroso cuidar no outro o que, no fundo, dói nela. Ou seja, projeta sua própria dor, sua própria necessidade de ser cuidada no outro e sente-se mal com isso, porque se sensibiliza e, paradoxalmente, dá o que gostaria de ganhar, sentindose no final injustiçada, embora tenha para dar, porque diz ter cuidado bem do namorado, quando este ficou doente na viagem. Tudo indica que o que ficou nela, o que faz parte de sua constituição subjetiva, são prioritariamente as lembranças da falta, de sorte que vive hoje como se ela tivesse descoberto que, na outra face da moeda do sentimento de desamparo/ressentimento (mais ressentimento que desamparo), estava a liberdade, aprendendo a trocar a primeira pela segunda, no contato com a vida, o que também lhe faz poupar repensar as dores "esquecidas".

Aos dez anos de idade já sabia cozinhar, porque a mãe não podia voltar para casa para fazer almoço para elas e, mesmo que o pai voltasse, tudo o que conseguia fazer era "miojo" todos os dias. Parece ter-se apegado muito à irmã, com quem confessa ser uma pessoa só, já que se sente muito ligada a ela, ainda que morem bem distantes uma da outra. Disso tudo, incluindo o fato de sentir que ainda precisava voltar para a casa dos pais, depois de cinco anos morando sozinha, nos faz supor a existência de uma lacuna presente em sua constituição subjetiva desde a infância, e que ela ainda tinha esperanças de curar esse "buraco", mas que, dado o não interesse da mãe por sua volta, tivesse desistido e simplesmente assumido outra forma de lidar com essa dor: afastando-se do outro. Assim, como que caído do ninho meio "sem querer", o passarinho aprendendo a voar, em parte por ressentimento, resolveu ficar longe de todos.

Parece um pouco pesada essa maneira de entender a história de Tatiana, mas foi exatamente assim que a pesquisadora sentiu, no contato com ela: como se existisse uma barreira impossibilitando um encontro mais confortável entre as duas. Ela estava incomodada, respondia bem as questões, mas não parecia querer ficar, da mesma forma como afirma que não pretende ficar em São Paulo.

Poderíamos pensar ainda na constituição de objetos internos não confiáveis e em sua dificuldade de construir uma alteridade subjetivada, no sentido de conceber o outro como aquele capaz de ajudá-la. Porém, não é tão simples, porque diz confiar plenamente na família e nos amigos, nos poucos e velhos amigos da infância. De qualquer forma, o grau de 
responsabilização que um vínculo amoroso compromissado exige é diferente do de uma amizade, e é isso que a afasta desse tipo de vinculação. Quer dizer, estamos compreendendo que não se trata de uma incapacidade de cuidar, de se responsabilizar, de respeitar e de investir reciprocamente num vínculo, mas simplesmente da escolha por não se responsabilizar, por não investir num vínculo, mas nela. Um tipo de estruturação narcísica em que importa mais o eu do que o outro.

Nesse âmbito, muito interessantemente, juntando seus elementos constituintes internos aos externos, ela mesma mostra o quanto sente que não consegue confiar nas condições de existências contemporâneas. Não tem esperanças quanto ao futuro e sente que tem "pouco tempo de vida". Pouco tempo de vida?

É. Sabe aquelas histórias que a gente escuta? Do meu avô... Meu avô adora contar história... É aquela coisa, eu faço ações de sustentabilidade na minha fazenda, porque eu quero um futuro melhor para os meus filhos e netos. Fazia sentido, hoje acho que não faz sentido. Você pensa assim: é para o mundo continuar? Eu não botaria filhos nesse mundo! Não que antigamente fosse melhor, mas acho que era mais tranquilo. Porque hoje a gente tem facilidades, fralda descartável, cada um da família com o celular, então a gente se acha o tempo todo, mas não sei se seria necessário tudo isso, se a vida não tivesse ficado tão louca, sabe? Porque o mundo tá tão maluco... Com esse excesso de informação, excesso de coisas para fazer... A gente tem um monte de atividades para fazer num tempo menor... porque a gente gasta mais tempo em trânsito! Com coisas desnecessárias! E aí para fazer aquelas coisas que a gente precisa fazer sobra menos tempo. E aí a gente precisa da tecnologia para nos ajudar! Eu não sei como meu pai trabalhava sem e-mail, mas as coisas aconteciam, né?

Tatiana fala muito pouco do pai, mas do pouco que fala a sensação que fica é que, com ele, tudo corre bem. Conta que não tem muito assunto com ele, mas que conversa com ele sobre assuntos financeiros, e que a mãe sente que são muito parecidos na maneira de pensar. Parece ser bastante identificada com ele, mas algo em torno do complexo edípico os afasta ainda. Pensamos que, nesses pais, exista alguma dificuldade de lidar com a própria sexualidade, o que de alguma maneira foi herdado por Tatiana em termos da sua capacidade de lidar com a própria afetividade.

Voltando aos questionamentos sociais, é como se ela sentisse na pele as mudanças que Kaës (2005b) salienta e as resumisse como falta de tempo e "pouco tempo de vida" para viver uma vida com qualidade, como a das gerações precedentes, quando investir no futuro fazia sentido e acreditar na vida também. Dessa forma, expressa sua desilusão quanto ao seu futuro e o seu não desejo por dar continuidade ao legado familiar, em face das instabilidades que assolam o mundo. Até porque sente que não tem futuro! Como se parte dessa descrença representasse uma consciência de uma dor por não poder contar com o continente externo para se desenvolver. Sente-se abandonada, igualmente como fruto de projeções do mundo 
interno, num ambiente que não lhe permite se sentir segura. Não se sentindo pronta para enfrentar a realidade externa e não podendo voltar para o ambiente materno, tendo que contar com a sociedade como continente psíquico, talvez não tenha encontrado nada muito confortável e tenha resolvido se fechar em seu envelope narcísico protetor:

- Gosto da minha aparência física, eu gosto de ser uma pessoa decidida, da minha objetividade. Eu acho que só não estou sendo objetiva para esse tipo de entrevista...

- Mas você não precisa ser objetiva aqui...

- É, mas eu sou do tipo de que fica impaciente... e as pessoas acham que eu sou grossa. As pessoas já reclamaram que, em mensagem, eu não boto ponto nem mando beijo. E acho que às vezes eu meio que atropelo as pessoas, assim...

A sua impaciência e objetividade mais se parecem com um tipo de defesa que dá sinal de alerta, quando sente que está caminhando por um terreno pouco objetivo, subjetivado, adentrando num campo que demanda profundidade e afetividade. A imagem que apareceu à pesquisadora foi como se, durante a entrevista, ela se visse andando num campo cheio de lama e quisesse ir embora rapidamente. Assim, entendemos por que somente o que é passageiro e rápido lhe agrada. O que é profundo e da ordem da afetividade a incomoda, porque terá que ter o trabalho de se "lavar" depois de tanta "sujeira". Como se o vínculo a convidasse a lidar com o que há de "sujo" nela, ou nos pais, como se tivesse herdado um sentimento incômodo sobre a vida muito próxima do outro. Uma herança transgeracional que espera ser transformada? Uma dificuldade de representar a afetividade? E, em face desse malestar, ficar distante pareceu ser uma saída, essa solução de compromisso que arranjou pareceu ser legítima, quando uma tia sua lhe explicou:

Eu passei as minhas férias no Peru... e minha tia que mora lá me disse que tem pessoas que nasceram para fazer família e outras não. "O seu tio, por exemplo, não. Ele sempre foi ausente, ele dá a vida para o trabalho, ele é prefeito... e ele já tá no terceiro mandato. Mas mesmo antes de ser prefeito, ele tinha uma fábrica e dava tudo para fábrica..." Então eu fiquei mais sossegada, porque tem gente que vê que algumas pessoas não nasceram para isso! E acho que hoje tem um monte de gente assim. Então, eu fiquei mais tranquila... e minha mãe não, ela fica mais preocupada... Mãe é mãe, não é tia, né?

Se, por um lado, a tia, como parte representante da geração precedente, compreende e legitima a sua escolha, por outro lado, Tatiana sabe estar desagradando à mãe por não corresponder às expectativas dela, e um sentimento de culpa persiste, porque a dívida geracional assim não seria paga. Contudo, podemos pensar ainda em uma forma que Tatiana encontrou de opor-se aos pais, que, ao seu modo de entendê-los, nunca souberam reconhecêla.

- A mãe te pergunta: "Não tá na hora de casar? Não vai comprar um apartamento?"

- Então você sente uma cobrança da sua mãe? Machuca? 
- Machuca. Ela nunca falou diretamente, mas ela fala dos amigos, que casou com o médico... Porque também tem essa cobrança de ter nível social, sabe? E eu, no Rio de Janeiro, já fiquei até com favelado... [risos] Para mim hoje já não tá fazendo diferença... E minha mãe me compara com minhas primas encaminhadas, minhas amigas, quase todas já estão casadas... Até comprar um apartamento é uma coisa que me incomoda um pouco, porque não quero enraizar... Depois de São Paulo, queria ainda morar em outro lugar!

A pesquisadora só perguntou se machucava, porque deve ter sentido inconscientemente que machucava. E a dor é significativa e se junta com o sentimento de não ter sido reconhecida em suas qualidades, em suas escolhas, a vida inteira. Mas, agora, é como se, cansada de procurar por isso, tivesse simplesmente aceitado o fato: "Para a família eu sou meio uma decepção... para os meus avós... Exceto minha tia, né?”. E, ao mesmo tempo em que incomoda sentir-se não correspondendo às expectativas dos pais, diferentemente de alguns de nossos participantes, a sua opção por não ter um vínculo amoroso compromissado parece ter sido uma decisão pensada, subjetivada, como aquilo de melhor que ela sente que pudesse oferecer a si mesma.

Contudo, imaginamos também nas bases desse desejo um contrato narcísico enfraquecido com os pais, mais por parte dela do que pelos pais, diante do ressentimento pelo não reconhecimento de suas potencialidades e desejos como filha. Dessa maneira, ela também se vê sem futuro, porque, como Eiguer (2008) enfatiza, o sentimento de não ter sido reconhecida pelos pais interfere no contrato narcísico, o que seria essencial para a construção do desejo de levar adiante o legado familiar, os sonhos dos pais. Isso afeta a idealização de projetos sobre o futuro. E ela se sente meio "patinho feio", acha-se diferente da "família de engenheiros", porque escolheu publicidade, por se perceber mais extrovertida que o restante da família, por gostar de viajar e (porque) procura pela legitimidade por ser diferente.

No entanto, tudo se passa em uma sociedade em que a dívida geracional e o ser "diferente" podem tranquilamente ser pensados e repensados: "Então eu fiquei mais sossegada, porque tem gente que vê que algumas pessoas não nasceram para isso! E acho que hoje tem um monte de gente assim. Então, eu fiquei mais tranquila...”. Assim, entendemos que Tatiana, sentindo-se ressentida e pouco identificada com esse modelo dos pais, que se casa às pressas, que se compromete com as responsabilidades e se esquece de olhar com mais cuidado para as filhas, procura se afastar desse modelo, afastando-se de um vínculo amoroso compromissado. Como se também não houvesse a possibilidade de fazer diferente. Para isso, o incômodo que sente, ao precisar cuidar de um outro e a vida estável e "monótona" que levaria devem contribuir. 
Podemos ver, em sua constituição subjetiva, traços de uma defesa "narcísica moderna" (Costa, 2003), por sentir o mundo como um lugar hostil do qual precisa se defender. O "modelo do consumismo" está no modo como se dão seus vínculos amorosos hoje em dia: efêmeros e avessos a todo tipo de compromisso. E o "modelo tecnológico", do "utilitarismo do outro" está igualmente presente em sua subjetividade, quando comenta, por exemplo, que uma das vantagens de se ter um vínculo compromissado é a de que poderá contar com essa pessoa, quando precisar...

A vantagem é que você tem a pessoa ali, na hora que precisar. Você não vai chamar um caso, um ficante, para comprar um remédio, porque você tá passando mal. Mas, se você mora com a pessoa, ela vai fazer questão de cuidar de você, porque ela mora com você, porque gosta de você... né? Eu cuidei do ex na viagem, porque eu quis, porque na viagem a gente tinha plano de saúde, então, tinha médico de sobreaviso...

Novamente, a questão do cuidado. Nessa passagem, ela deixa transparecer que, para ela, morar com outra pessoa significa ter alguém que vai fazer questão de cuidar de você porque gosta, mas não que isso signifique sentir-se bem de ser cuidada, uma vez que ela sabe que cuidou do ex-namorado a contragosto e, da mesma forma, não quer se sentir um incômodo na vida de uma outra pessoa, assim como sente que incomoda os pais? Em decorrência, parece que prefere se sentir incomodada e se afastar, a saber que o outro se incomoda com a presença dela. Tudo aponta para uma constituição em que optar por ficar solteira, sem um vínculo amoroso compromissado, tem também suas bases num mecanismo de defesa. De defesa em relação ao outro, que pode frustrar, decepcioná-la, e ainda se tornar dependente dela. Ela tem medo de se tornar dependente emocionalmente de outra pessoa, porque sente que no fundo era esse seu desejo e sabe que o outro pode decepcioná-la, precisando de mais cuidados que ela possa dar, ou mesmo indo embora. Ela então se fecha para todas as possibilidades.

Nesse contexto, o mito da "individualidade", da "mulher de êxito", da "independência afetiva", da satisfação que encontra em uma vida preenchida por atividades e trabalhos, pode ser entendido como um tipo de solução de compromisso, uma maneira própria da contemporaneidade de construir a subjetividade, em face de seus conflitos internos, de onde consegue obter prazer, satisfação e reconhecimento através do sucesso no trabalho. O que está de acordo com uma sociedade que cultiva esses valores como uma alternativa de bem-estar, como ideais e fontes de reconhecimento, de onde advém sua "autoestima".

Finalizando, tudo leva a crer que o ressentimento de não se sentir reconhecida pelos pais fez de Tatiana uma pessoa com dificuldade de conceber a alteridade como aquela pessoa capaz de reconhecer suas necessidades e cuidar dela. Tudo indica que ainda sente que precisa 
muito desse cuidado, todavia, da mesma forma que os pais não souberam fazer, generaliza esse sentimento e teme que, em algum momento, irão falhar com ela. E certamente isso acontecerá, já que estar num vínculo supõe a necessidade de lidar com a frustração de que, de tempos em tempos, o outro não corresponderá com as nossas expectativas. Poderíamos supor que, imersos numa sociedade que pouco oferece em termos de conforto existencial, qualquer um que busque por um vínculo espera encontrar esse conforto, fazendo do outro uma fonte inevitável de dor e frustrações, porque ambos esperam antes receber do que dar?

O modelo geracional de vínculo que Tatiana recebeu pôde ser pensado, fantasiado, mas foi transformado e apropriado de tal maneira que ela não pensa em ter um vínculo igual ao dos pais, nem consegue imaginar um vínculo diferenciado. Nesse caso, supomos que o contrato narcísico enfraquecido com os pais e a falta de identificação com eles interferem no desejo de levar adiante o legado familiar, e dificuldades em torno da representação da afetividade são desfavoráveis à formação de um vínculo estruturado e estável. Contudo, não podemos deixar de lado o prazer que ela sente de se ver como um pássaro, uma construção subjetiva que a deixa satisfeita com a vida que tem e parece criativa.

\section{João Pedro}

Apresentando-se de um modo muito particular, para João Pedro ter honra e dignidade é mais importante do que viver. Em sua visão, a vida resume-se à dívida que cada japonês assume com suas obrigações de dar continuidade aos valores que julgar relevantes. A questão da transmissão para ele é sobressalente, mas, aos 34 anos de idade, ele parece bastante confuso em relação a como dar continuidade a essa herança psíquica geracional, cujo peso é aparentemente quase insuportável, quase um paralisante.

Neto de japonês, irrita-se com o "modo brasileiro" de dar um "jeitinho" em tudo, já que procura ser sempre o mais objetivo possível em suas ações, nos seus relacionamentos, o que nem sempre é bem compreendido e o faz se passar por uma pessoa insensível. Insensível realmente ele não era, mostrou-se bastante disponível para a entrevista, para explicar seus pensamentos, teorias sobre a vida e sentimentos. O que a pesquisadora sentiu de João Pedro é como se, no fundo, carregasse certa mágoa e incompreensão pela vida e, por isso, um comportamento um tanto defendido. O que, na verdade, revela justamente o contrário: parece ter uma sensibilidade à flor da pele, que o faz se isolar de um mundo que o machuca. Tudo é vivido com muita intensidade e tem um caráter de profundidade, como se fosse preciso a cada 
momento reexaminar sua existência, porque ficam no ar questionamentos que o impedem de viver a vida de um modo mais leve. Lembrando-se de sua infância com detalhes, contou sobre seu primeiro dia de aula:

E quando eu cheguei em casa foi um choque, porque descobri que ela [sua mãe] não estava lá, porque ela me perguntou como foi o meu dia. E ela disse que eu tinha que brincar, que não era para ficar parado num canto. Aí, no segundo dia, eu fiz de tudo, como toda boa criança de sete anos, aliás, tinha sete anos e meio! Minha mãe sempre insistiu nesse meio ano e isso me prejudicou a vida! Bom, depois eu conto... No segundo dia eu brinquei que nem um louco, mas eu também me senti na obrigação de correr... e eu corri, me esforcei para fazer alguma coisa e isso foi estranho, porque eu me lembro claramente. E isso me marcou muito de ter que desempenhar um papel...

Em seu primeiro dia de aula, ficou imaginando que a mãe o estaria olhando de longe e por isso não quis brincar, procurou se comportar ao máximo. Porém, como descobriu que essas não eram as expectativas da mãe, mudou completamente seu comportamento, mas, como ele mesmo afirma, nenhuma das duas crianças eram realmente ele. A necessidade de agradar as expectativas de sua mãe parece ter moldado sua vida, sua personalidade, criando um "falso-self" (Winnicott, 1975), o qual o impediu de ser espontâneo, provavelmente, por muitos anos. O sentimento de estar desempenhando um papel o acompanha desde criança.

João Pedro conta que foi uma criança muito esforçada e dedicada, que aprendeu a ler, a escrever e a fazer contas com sua mãe, antes de entrar na escola. Entretanto, as lembranças do passado, apesar de vívidas, são também bastante dolorosas. A relação com a mãe parece ter sido sempre perpassada por uma angústia diante da cobrança onipresente por ser o filho mais velho, o responsável não só por levar os valores da família adiante, mas por trazer melhores condições de vida a eles, visto que parece que viveram com poucas condições financeiras por algum tempo. A mãe parece ter sido a responsável por instigar nele uma responsabilidade pelo grupo familiar maior que a do seu pai, que podemos conceber como aquele que não foi capaz de atender às expectativas da esposa.

João Pedro não quis entrar em detalhes sobre o pai. Conta que não sabe de onde herdou os valores que carrega fortemente, quanto à honra e à dignidade, pois seu pai dizia o contrário, que preferia "ser um covarde vivo que um herói morto", embora mesmo assim haver morrido cedo. Sente que foi a mãe quem o educou verdadeiramente, já que o pai tinha uma vida pouco regrada, foi um "contraexemplo", mas como já é falecido, preferiu não falar mais sobre ele, para não ferir sua dignidade. João Pedro não demonstrou ter orgulho do pai, pelo contrário.

A seriedade e o comprometimento com o passado são marcantes em João Pedro. Um passado que, por um bom tempo, condenou o presente e o futuro, algo que procura resgatar 
atualmente. Como sempre foi uma criança muito inteligente, sentiu que estava predestinado a entrar no ITA (Instituto Tecnológico de Aeronáutica), mas, apesar de todos os esforços, não passou nos exames. Prestou vestibular para Química em uma instituição de ensino pública e isso lhe foi tão fácil que não conseguiu lhe dar o devido valor. Toda a graduação foi sentida como um castigo, como um "prêmio de consolação".

\begin{abstract}
Mas foi difícil, vou dizer que a vida universitária inteira foi uma batalha para tentar me recuperar, esse trauma de ter morrido. Japonês tem uma coisa, se você falha, você tem que morrer. E eu não tinha morrido, nada. E não tinha sentido eu estar aqui. Mas eu tinha outros motivos para estar aqui, o que me levou a me reestruturar também. Mas eu também não tinha motivos para morrer, porque também é preciso morrer de uma forma honrosa. Não é suicídio. Quando você faz isso, você entrega aquilo que você tem de mais importante, porque você tem que pagar algo com o valor máximo. E se você me perguntar se eu faria: eu faria, sim! Do japonês mais miserável até o mais nobre, todos entendem o valor de dignidade. Não tem nada a ver com orgulho, a vida não é tão importante assim em relação à honra, à dignidade. Quando eu perdi para o ITA, foi uma coisa... E aí que tá, eu não perdi! Depois que eu fui reconstruindo o que eu tinha feito. Eu devia ter feito o máximo com o que eu tinha nas mãos, eu podia ter sido um excelente químico, podia estar no doutorado agora, eu podia ter ido para a área espacial, se eu tivesse visto o que eu tinha nas mãos. Mas eu não reclamo não, hoje em dia eu vejo outras possibilidades. A grande lição do ITA foi: faça agora o melhor com o que você tem nas mãos! Não importa o que você queria, use isso, use isso!
\end{abstract}

Perder, ou não ter perdido, para o ITA foi um marco em sua vida, sem dúvida. Parece ter sofrido anos depois, durante quase toda a graduação, do fato de não ter conseguido realizar o seu sonho. Ou o de sua mãe? O sentimento da pesquisadora é de que nada do que contou - e contou realmente bastante sobre sua vida - pertencia-lhe por inteiro. Havia no vínculo formado entre ele e a pesquisadora uma atmosfera de compreensão, porque, pelo viés da contratransferência, surgiu um sentimento de muita proximidade, compaixão e ao mesmo tempo admiração pela maneira como parecia envolvido consigo mesmo. Como se ele vivesse numa batalha interna constante, em que a principal questão envolvesse, primeiro, "como ser quem se é", e somente depois "como estar com o outro". Em outras palavras: como fazer de sua história, de sua herança um continente habitável, apropriando-se da mesma e transformando-a, de onde um Eu criativo pudesse emergir.

Fazer o certo onde todo mundo faz o errado é ofensivo. Teve uma vez que eu andando sozinho pelas ruas, porque eu andava muito sozinho de criança, vi uma romã. Vi e queria a romã, fiquei horas ali pensando se pegaria ela ou não... Foi um Jardim do Éden, e eu não peguei a maçã, fui embora sabendo que fiz o certo! E foi muito bruto, porque era eu comigo mesmo, $e$ o portão estava baixo, era aberto. Mas foi minha primeira grande vitória de perceber que eu era capaz de fazer o certo, e isso veio da minha mãe, porque meu pai só fazia coisas que não podia... E então eu assumi esse papel, de defender a casa, de proteger! Eu tive que assumir este papel, porque sei que meu pai não dava conta.

Em outras palavras, o legado materno, mais ligado às leis e à norma, venceu em oposição ao legado paterno, mais associado a uma vida desregrada, pouco admirável por ele, 
de onde podemos pensar haver um desejo inconsciente de ser como o pai, porque a batalha interna revela a necessidade de o desejo consciente ser mais forte que o inconsciente. Nesses termos, podemos ler que, embora conscientemente esteja mais identificado com a mãe, com as expectativas dela, o seu desejo inconsciente de ser como o pai pode tê-lo "impedido" de passar no ITA, de sorte a não atender às expectativas da mãe e, quem sabe, poder desfrutar da liberdade de ser quem gostaria de ser de verdade, abrindo para si uma possibilidade de construção subjetiva mais verdadeira e criativa.

Nessa passagem, ao conseguir não pegar a romã, ele relata sua percepção da possibilidade de seguir o legado materno, ainda que reinasse nele o desejo inconsciente de seguir o legado paterno, até o momento em que não passou no ITA. E, então, podemos entender o sentimento de fracasso posterior. Contudo, ainda hoje parece necessitar de um controle grande para não se render ao lado paterno, concebido como "mal", e espelhar-se no lado materno, tido como o "bom", admirável, mas não apenas. Tem algo nessa batalha de um "instinto de vida" contra um "instinto de morte", que se complica pelo fato de que escolher pelo "instinto de vida" significa assumir uma dívida com a mãe, abrir mão da própria vida, perder em identidade (desempenhar um papel) e ainda ocupar o lugar do pai; enquanto escolher pelo "instinto de morte" parece ser mais tentador, porque ganha em liberdade, mas seria sentido como um fracasso, além de ameaçador da própria vida. Haveria a necessidade, portanto, de uma integração de "mãe" e "pai" dentro dele.

Sua mãe foi a pessoa mais honesta que ele conheceu em sua vida, além da mais simples, aquela que o ensinou a fazer o certo e o educou para assumir o papel de homem da casa. João Pedro pareceu ser totalmente identificado com a mãe, com quem também "assinou" um contrato narcísico bastante forte, pois foi ela quem investiu nele narcisicamente: ela quem depositou nele as esperanças, atribuindo-lhe a missão de trazer melhores condições de vida à família. Assim, supomos que João Pedro, desde pequeno, vive o conflito dos ideais de ego internos consciente, de ser como a mãe, e inconsciente, de ser como o pai, visto que, mesmo o pai tendo desagradado ao grupo familiar, foi ele quem a mãe escolheu. Um conflito de difícil resolução, porque a herança psíquica paterna parece estar ligada a um sentimento de revolta, pelo pai representar uma decepção com relação aos próprios antepassados, mas também por não ter desempenhado o seu papel de pai e ter restado a ele fazê-lo. João Pedro possui um legado que precisa ser transformado para ser apropriado: como entender que a mãe escolheu e rejeitou o pai? Que herança psíquica é esta que o pai carrega, que não foi capaz de cuidar do grupo familiar? E, além disso, coube a ele uma tarefa difícil de executar, a despeito de muito 
tentadora: a mãe deu-lhe o lugar do pai, porém, como assumir esse lugar sem sentir o peso da culpa edípica?

E como parece ainda não ter conseguido resolver esse grande dilema, precisou se afastar. Afastou-se da mãe por muitos anos, bem como da única irmã, morando sozinho com seus três cachorros e uma gata, que diz ser sua família. Um afastamento que se justifica pelo modo como talvez se sinta, identificado com o pai, que falhou perante as expectativas da mãe.

(...) pelo fato da gente ser pobre, ela [mãe] tinha expectativas de que eu tirasse eles daquela pobreza, filho mais velho, homem! Então, tudo isso era um peso enorme! E talvez no dia em que eu não passei no ITA me quebrou as pernas, eu virei poeira!

Dentro de nossas hipóteses, não passar no ITA representa a maneira que encontrou de não assumir o lugar do pai, ainda que para isso precisasse virar "poeira". O que poderia significar a força internalizada das leis do interdito cumprindo sua função saudável à estruturação psíquica. Hoje, ele terminou a faculdade depois de muito esforço, porque realmente não conseguiu se empenhar no curso e, na atualidade, dá aulas de química em escolas para crianças. Mesmo seguindo a vida, ele sente que fracassou. Sente-se muito culpado e seu único álibi são aqueles seis meses de diferença, por ter entrado na escola com "sete anos e meio" que o impediram de tentar novamente entrar no ITA, onde há limite de idade para prestar a prova.

Em meio a essas malhas constitucionais, que mais parecem cheias de nós, a alteridade resta um tanto quanto nebulosa, é concebida como estranha e ele facilmente consegue se afastar do outro, que inclusive parece ser concebido muito mais em teoria. A única pessoa em quem confia um pouco é sua mãe, porque confiança para ele é "uma coisa de que você mataria e morreria por ela". Seus valores fortes e bastante pesados provavelmente o empurram para longe de uma sociedade na qual as pessoas não compartilhariam facilmente desses teores. Nossa análise supõe ainda um João Pedro desadaptado, descontextualizado, numa sociedade em que o modelo da tradição foi substituído pelo modelo do "faça como quiser", pelo modelo individualista com valores bastante diferentes daqueles que estruturaram sua subjetividade.

Eu não entendo como a sociedade pode ser tão... que deixa pessoas morrerem de fome, em frente ao local em que tem comida. É como se as pessoas estivem loucas coletivamente! Não entendo como pode deixar o povo viver de aluguel. As pessoas nem querem saber como podem ajudar. As pessoas se esforçam muito para saber o que interessa para elas, mas não para doar algo, para fundar uma associação... Não compram um prédio para formar uma escola. E se formar é para gerar dinheiro. Esse mundo é de hipócritas, é para gerar hipócritas... Estamos num nível muito baixo. Muito pouco. É isso... 
João Pedro reclama de um continente social hostil, que está muito associado a questionamentos internos, através da projeção de seu mundo interno, mas também com sua história de vida muito sofrida na infância, além do real contexto social. De qualquer forma, é como se vivesse num mundo incompreensível, onde a incompatibilidade entre o que se passa em seu mundo interno e no das outras pessoas, incapazes de ajudá-lo, o fizesse se recolher num tipo de narcisismo, como aquele descrito por Costa (2003), atinente a uma dor de viver num contexto social que faz sofrer.

Eu acho que eu sou espontâneo. As pessoas acham que eu sou muito autoritário. Mas acho que sou mesmo, pelo sistema brasileiro emocional. Falo emocional, porque não é racional. As pessoas sentem que eu sou muito fechado, mas eu só acho que estou na minha... Não que eu não me importe com os outros, eu me importo muito, mas não adianta nada sofrer por eles. (...) Sinto que não tenho necessidade de eu me fundir com algo que eu não acredito para ser mais um... Então, a minha personalidade é uma coisa isolada. E eu não me misturo, porque não quero me perder! E eu preferi me isolar para não chocar, porque eu percebi que o isolamento choca demais as pessoas, demais mesmo, pode ser agressivo isso.

Ele carrega uma mágoa pelo modo como não se identifica com o mundo externo ou como o mundo externo não o ajudou a se estruturar como sente que precisava, pela maneira como o mundo externo não esteve adaptado às suas necessidades, o que também pode ser lido como mágoa do pai. Um pai que não soube seguir a tradição, cultuar os valores por ele tão admirados e, da mesma forma, estendendo esse sofrimento ao ambiente, julga a cultura de onde vive como aquela incompatível com a que vive internamente, herdada de antepassados de outro país. Ele vive uma dicotomia cultural. Podemos, por conseguinte, inferir que a admiração pelos valores tão fortes e estáveis relaciona-se com uma necessidade psíquica de que o ambiente sociocultural o ajudasse a providenciar um espaço de subjetivação, onde leis bem demarcadas, principalmente, com relação ao interdito, lhe garantissem a segurança de conseguir prosperar em sua carreira, ajudar o grupo familiar, sem sentir que assim ocuparia o lugar do pai. Desse desapontamento resulta uma agressividade, num tipo de funcionamento psíquico que concebe o "bem” versus o "mal”, próprios da posição esquizoparanoide (Klein, 1946/1991).

Em seus códigos emocionais particulares, amar significa servir, relacionar-se significa desistir de si, e essa doação é vista como um ato de muita coragem. Contou de algumas meninas, quando criança, pelas quais se apaixonou e que o trataram mal; contou que a memória de sua irmã é bem maior do que a sua e que ela só se lembra das coisas ruins que ele fez para ela... Contou igualmente uma história que parece ter sido bem marcante, de uma moça por quem se apaixonou intensamente, ao passo que ela, sabendo dessa situação, pareceu ter-se aproveitado enquanto pôde, até que ele, percebendo que ela jamais ficaria com ele, 
resolveu desistir dela com uma dor imensa. As mulheres pelas quais se interessa têm uma personalidade um tanto quanto autoritária, impositiva, o que parece fazê-lo se sentir impotente e pode ser lido como algo a favor de nossa hipótese da identificação inconsciente com o pai.

Há alguns anos atrás, namorou uma moça que, para ele, estava mais interessada nele enquanto "provedor" do que enquanto pessoa, porque ela tinha um filho e ele sentiu que ela estava procurando a todo custo um pai para a criança. Esse relacionamento muito o incomodou, todavia, porque ele sentia que "estava voltado para a estabilidade".

Na verdade, eu acho o seguinte: ela estava precisando de alguém, mais do que eu precisando dela e aí acabou acontecendo. Ela é muito bonita, mas nesse momento ela estava precisando de uma companhia. Mas foi uma coisa muito estranha, foi uma relação muito voltada para a estabilidade! Então, você tem uma pessoa que está ali. Não sei te explicar: é tão estranho, porque não é pai, não é mãe, é uma pessoa que está ali. Vamos dizer assim, é que nem um cachorro.

Dado o contexto de sua constituição subjetiva, cremos parecer natural sentir-se incomodado no lugar de provedor. Significaria viver mais intensamente o conflito interno, quando ainda sente que pode perder para o lado do desejo inconsciente e fracassar nessa tarefa, tornando-se igual ao pai. Essa parece ser uma das vertentes da resposta para o porquê não se sente pronto para um vínculo "voltado para a estabilidade", acrescentando-se a isso sua dificuldade de conceber a alteridade de um modo subjetivado.

Isso eu não sei julgar, se é bom ou ruim. Tá ali, é bom se for um cachorro, mas se for uma pessoa é muito complicado. Um cachorro está ali porque ele realmente quer estar ali, uma pessoa está ali porque algo ela quer dali. $O$ cachorro pode querer comida e isso você pode dar, mas a pessoa, você não sabe o que ela quer! E ela acha que você tem que saber o que ela quer. Não falo só de mulher, os homens também são assim. Mas analisar o que uma mulher quer é muito mais complicado, elas são mais complexas, porque têm um grau de inteligência emocional muito mais desenvolvido... Em geral, as mulheres se adaptam, e elas sofrem mais por causa disso, mas enfim...

Essa moça, aparentemente, foi a única mulher em sua vida que parecia ser uma pessoa mais sensível ao que ele era, diferentemente das outras, de suas expectativas de "mulheres más", porém, parece que ele não pôde reconhecer isso para além da necessidade dela de ter um companheiro como um pai para seu filho. Isto é, reconhecê-la para além de suas expectativas sobre as mulheres, de sua herança psíquica, de suas projeções. Disso advém sua dificuldade de investimento num vínculo, de reconhecimento do outro, porque a alteridade está atravessada por suas fantasias e projeções. Não entende o que os outros querem dele e, se entende, supõe com frequência ser de origem interesseira, como se ele mesmo não pudesse supor qualidades em si próprio. A identificação inconsciente com o pai pode ter-lhe trazido esse sentimento. 
Nesse sentido, fecha-se narcisicamente num movimento em que as opiniões alheias sobre ele não têm importância, porque julga o outro de antemão como aquele que não vai compreendê-lo, e porque julga muito a importância de seus valores maior do que a opinião alheia. Um mundo interno povoado de fantasmas, objetos internos pouco confiáveis, que projeta e dificulta o processo de diferenciação do outro e o de vinculação. Seus vínculos são instáveis, tem poucos amigos, e vive muito sozinho. Em seu universo particular, casar-se e ter filhos só será possível se antes encontrar uma mulher que o compreenda perfeitamente, já que ela seria quase como um "duplo" de si mesmo.

Preciso de alguém que valorize os mesmos valores que eu. Sabe por quê? Eu mesmo não tinha consciência dos meus valores e quando eu me dei conta que educar uma criança com os meus valores é muito importante para mim... Isso é muito importante, isso eu não posso perder. Eu não posso simplesmente abrir mão disso, em função de uma mulher que tenha as manias dela etc. Preciso de uma mulher que me ajude a fazer com que os meus valores não se percam, isso é muito importante para mim. Isso é uma escolha minha de viver. Você vê a diferença? Não vejo mais o relacionamento como satisfação de desejos... mas um compromisso com o meu passado! Eu vejo hoje em dia que as pessoas valorizam muito pouco isso, passado, valores... muito pouco mesmo.

Por enquanto, João Pedro não quer ter um vínculo compromissado, porque é como se estivesse "fechado para balanço", em transformação. Uma insegurança grande quanto ao futuro, em função da herança pesada e do medo de novamente fracassar, de ser como o pai, o afasta na verdade da construção de sua história. Tudo se passa como se lhe fosse quase impossível resolver os conflitos que carrega, em virtude de sua herança, porque o espaço "onde o eu pode advir" (Aulagnier, 1979) parece ter ficado comprometido, diante de um contrato narcísico esvaziado com o pai e um contrato narcísico forte com a mãe, que parece passar pelas vias de um interdito não bem delimitado. Tais falhas nos contratos e mesmo no processo de identificação com o pai podem ter interferido nas garantias da vida psíquica, que, por sua vez, interferem nos processos de mediação e de transformação da pulsão, na concepção da alteridade, de formar vínculos estruturados e estáveis e, sobretudo, transformar a herança apropriando-se da mesma.

Soma-se a isto uma mãe que escolheu um homem incapaz de atender às suas expectativas, revelando a existência de conflitos edípicos inconscientes anteriores a João Pedro, uma herança transgeracional, que parece ter sido passada a ele sem transformação, restando-lhe resolver, postergando com isso a própria vida.

Ah, para ser sincero, eu não sei. Porque eu não vou ficar projetando uma coisa que eu não posso alcançar! Eu tenho expectativas, eu sei para onde eu quero ir, mas onde eu vou estar... eu não sei. Eu quero ter uma pós-graduação forte. Ir para área de pesquisa científica. Educação. Eu tenho que me especializar, porque hoje em dia educação precisa de mestrado para poder ganhar alguma coisa. Um outro objetivo importante é me formar em artes 
marciais, por quê? Eu descobri que um dos grandes objetivos meus é ser um elo, um elo de ligação, de transmissão, é uma bênção muito forte manter essa arte intacta, para passar para outras pessoas... Uma responsabilidade de manter uma coisa que está inalterada há séculos. Isso no Japão se chama tesouro vivo. E eu fui eleito por um carma do destino... E hoje em dia isso não é importante para as pessoas, o importante é dinheiro, o que eu vou comprar com isso...

João Pedro é um belo exemplo de alguém que, tomado pelo peso de sua herança psíquica intergeracional e transgeracional, parece preso, procurando uma saída para transformar essa dívida de uma forma que se sinta honrado e possa viver bem. O modo como supõe que pode resolver os conflitos psíquicos, por enquanto, é sendo um elo apenas no nível cultural, podendo ser o transmissor da cultura, da honra e da dignidade que o pai não soube fazer, assim também se assegurando da introjeção das leis, da cultura. Uma companheira só é possível de ser pensada, por isso, dentro desses moldes. Aquela que fosse também incumbida de levar os valores orientais adiante, e poderia compreendê-lo em suas angústias e ajudá-lo a estruturar-se diferentemente do pai, como deseja conscientemente. Alguém, ainda podemos supor, capaz de ajudá-lo a estruturar-se melhor psiquicamente, pelas leis e normas bem delimitadas.

Portanto, João Pedro não compactua com os mitos e crenças em torno do consumismo, mas o modo como concebe a alteridade e mesmo essa moça dos seus sonhos está em consonância com o "modelo tecnológico", quando o outro é visto como alguém que pode ser disponibilizado para suas próprias necessidades psíquicas. A forma como procura se defender narcisicamente do mundo aponta para um sofrimento que tem origem em seus conflitos psíquicos: ele projeta um mundo externo que é incapaz de ajudá-lo, mas esse mundo é igualmente condizente com as condições de existência contemporâneas. Ele sente falta de um mundo mais compromissado com o passado, com a tradição, talvez porque sente que esses valores teriam ajudado a melhor se estruturar. Um pai, mas também um mundo, que não tivesse lhe imposto um trabalho desonesto: é como se lhe tivesse restado fazer tudo sozinho, cultivar valores estáveis, apropriar-se deles para não cair na tentação de ocupar o lugar do pai de modo incestuoso e ainda se apropriar de toda a herança recebida para que, então, um Eu pudesse emergir.

Finalizando, supomos que a opção de João Pedro por não ter um vínculo amoroso compromissado pode ser compreendida em face de sua impossibilidade de estar num vínculo sem que este o remeta a pensar em toda a herança psíquica geracional e se sinta angustiado ante a tarefa que lhe restou. Ele precisa transformar o herdado de um modo criativo, garantindo-lhe a saúde psíquica longe das expectativas da mãe, mas não tão longe que o faça 
se sentir fracassado. Seria necessário um processo de integração dos legados recebidos, recuperar aspectos bons recebidos do pai e reconsiderar as expectativas da mãe. O sentimento de culpa por não ter cumprido ainda com as expectativas da mãe não o ajudam, nem o modo como se identifica negativamente com os valores do pai, que apenas the serviu de “contraexemplo". Ou seja, estar num vínculo, para João Pedro, significa reeditar a própria história, repensar o passado, reprogramar o futuro e evitar cair em armadilhas inconscientes de terminar como o pai. Tudo isso é ainda pesado demais para ele. 


\section{Capítulo VII}

\section{Discussão e Conclusões}

Para darmos início à discussão, parece interessante trazer para o debate uma hipótese que perpassou a construção do projeto desta tese. Havia uma perspectiva que visava a compreender a relação que a efemeridade observada em alguns vínculos amorosos tinha com o cenário sociocultural e econômico contemporâneo. Supúnhamos que a falta de compromisso com que são formados os vínculos, atualmente, abordasse uma vertente diferente, para além de um modelo mais liberal de relacionamento que sempre houve: ou seja, que dizia também sobre uma fragilização com que os vínculos são compostos hoje em dia, como efeito de condições de existências específicas, conforme ressalta Bauman (2004). Nesse sentido, perpassava ao fundo também uma preocupação com o destino da família enquanto instituição. No entanto, como partíamos do viés psicanalítico vincular para compreender a formação do sujeito, supúnhamos igualmente um efeito considerável da herança psíquica geracional na composição do fenômeno, mas não imaginávamos de que forma nossos participantes poderiam apresentar isso.

Contudo, no transcorrer das análises, apesar de claramente identificarmos que o cenário contemporâneo tinha relação com o fenômeno estudado, compreendemos que foi marcante e fundamental para esse tipo de escolha amorosa o entrelaçamento das características da subjetividade provenientes desse cenário com aquelas de origem intrapsíquica e herdadas geracionalmente. Imaginávamos que a influência do contexto sociocultural e econômico no funcionamento psíquico poderia ter uma predominância na formação desse tipo de opção, mas os resultados nos levaram a entender que optar por não ter um vínculo amoroso compromissado é efeito de uma combinação de fatores psíquicos com aqueles provenientes da relação do indivíduo com a sociedade contemporânea. No caso de alguns participantes, como Gustavo, Henrique e Tatiana, é visível a profunda relação entre suas características subjetivas identificadas à atualidade e a opção por não ter um vínculo amoroso compromissado. Não obstante, outros deles mostraram que essas características subjetivas ajudavam principalmente a sustentar e validar uma opção muito mais associada a uma demanda interna. Para Patrícia, Isabella e João Pedro, é como se algo da ordem do 
funcionamento psíquico levasse a uma necessidade de fechamento para o outro, de sorte que se servissem das características da vida sociocultural atuais para sustentar essa demanda. De toda maneira, o cenário atual participa da construção e da sustentação desse fenômeno, porque a subjetividade de cada um está sujeita às influências das circunstâncias culturais e sociais nas quais o indivíduo está inserido.

Dentro desse viés, o que de imediato aparece em comum a todos os casos é um posicionamento que reflete a liberdade que sentem para fazer essa opção de não construir um vínculo amoroso compromissado. Vivemos num momento histórico em que tudo pode ser vivido e validado. Esse contexto permite-nos fazer escolhas e dá condições para que as sustentemos, sem que sejamos demasiadamente contestados ou nos sintamos excluídos da sociedade, de um grupo ou da família. Alguns pais de nossos participantes chegam a se manifestar, garantindo ser contrários a esse tipo de opção, pois gostariam de ter netos, mas não são enfáticos e praticamente não existe mais ninguém que os obrigue a se casar, como sabemos que ocorria em épocas passadas. Muito pelo contrário, nossos sujeitos não têm nenhuma preocupação em construir uma família, demonstrando com isso a ausência de uma “cobrança sociocultural” nesse sentido.

Outro aspecto notável da análise da construção subjetiva dos participantes foi a dificuldade em lidar com a frustração. Todos eles revelaram-se narcisicamente orientados, muito mais preocupados consigo mesmos do que disponíveis para o contato com o outro, para o reconhecimento da alteridade. Apresentaram-nos um narcisismo que representa um efeito do contato do sujeito com as condições de existência contemporâneas, como descrito por Costa (2003). Nossos participantes, no geral, esperam pouco do contato com o outro, não parecem acreditar em pessoas capazes de compreendê-los, evitam a intimidade e parecem estar distantes como "efeito de traumatismo", segundo assinala o autor. Retomando Rios (2008), a cultura contemporânea "reproduz conceitos e práticas que não sustentam a alteridade, e constantemente devolvem o sujeito para o miolo de si mesmo quando este procura referências fora de si, na experiência coletiva" (p. 423). Esses conceitos e práticas a que alude a autora, a nosso ver, são reflexos de falhas nas "garantias metassociais" (Kaës, 2005b) que indicam uma sociedade onde o poder do coletivo na organização do psiquismo fica diminuído e, como saída, o indivíduo volta-se para si. Em todos os nossos sujeitos, sentimentos de medo, descrença e insegurança oriundos de vínculos anteriores ou herdados psiquicamente os conduziam de volta a si mesmos e, em muitos casos, impediam um contato com o outro, em que este poderia realmente ser visto em sua essência. Todavia, estes são 
dados que apontam tanto para efeitos de uma sociedade competitiva, consumista, que muda a todo instante e valoriza o individualismo, quanto para efeitos de histórias de vida particulares.

Patrícia foi a primeira a ser apresentada, porque seu relato é revelador do quanto, no caso dela, se fechar em sua "capsula narcísica" a salva de um contato com o outro que não pode ser pensado para além de algo destruidor. Dessa maneira, se em parte o aspecto narcísico de sua subjetividade exibe um formato de fechamento que nos leva a estabelecer relações com as características da sociedade atual, por outro lado, o conteúdo que ela enfatiza é de origem geracional. Sua observação sobre os modelos de vínculos falidos construídos por pais, tios e avós a fizeram ter pouca esperança no estabelecimento de um vínculo amoroso apaixonado. Trata-se de uma expectativa interna formulada no decorrer de suas experiências com familiares, mas que também pode ser facilmente observada no cotidiano e que pode ser confirmada, já que ela vive numa sociedade que comporta possibilidades diversas e indivíduos mais voltados para si. Para Patrícia, o fato de ter uma "família desestruturada" a envergonha e a deixa sem esperanças. Porém, sua família apenas passou por reconfigurações próprias da contemporaneidade: seus pais estão casados novamente e parecem satisfeitos. Por isso, imersa numa experiência coletiva contemporânea, ela sente falta de contratos mais duradouros e satisfatórios e, não tendo esperança disso acontecer, no contexto atual, prefere se isolar.

A complexidade das análises está no fato de que nem sempre um aspecto desse fenômeno comporta somente uma dimensão que pretendemos abordar: ou seja, associada com as condições de existência ou com a herança psíquica e o intrapsíquico. Esse mesmo dado de Patrícia revela, por exemplo, a dificuldade dela de desligar-se do modelo herdado e pensar numa possibilidade de construção diferenciada. Nesse sentido, denota ainda sua dificuldade em sair do lugar de filha e ver-se como adulta, herdeira desse modelo, porém apta a construir um outro tipo de vínculo. Portanto, entendemos que a composição do fenômeno estudado implica uma combinação de fatores externos e internos ao psiquismo.

De maneira geral, acreditamos que o modo como se constrói a opção por não ter um vínculo amoroso compromissado leva em consideração os conteúdos psíquicos de cada um, de ordem intrapsíquica e/ou herdada geracionalmente, mas a forma como esse conteúdo se manifesta está em consonância com os modos de ser da contemporaneidade. Isto é, há diversas maneiras de se expressar o que se sente e de se elaborar os conflitos, e as criações culturais são justamente invenções decorrentes do contato com a realidade externa para que o sujeito consiga se organizar e se adaptar. Dessa forma, entendemos que o movimento de se isolar, de descartar o outro ou usá-lo em seu benefício deve ser compreendidos como soluções 
de compromisso próprios de nossa época. Assim, concluímos que os fenômenos do "narcisismo moderno", do "modelo do consumismo" e do "modelo tecnológico" possuem relação com o fenômeno estudado, mas enquanto representantes de funcionamentos possíveis de relacionamento em nossa sociedade, uma vez que o porquê dessa eleição está associado a conteúdos internos. Isso também explica o fato de nem todos os sujeitos utilizarem esses recursos, considerando o outro como um objeto de uso ou de fácil descarte, apesar de todos se mostrarem pouco disponíveis para um contato mais profundo. $\mathrm{O}$ fenômeno do narcisismo exacerbado foi verificado em todos os participantes, mas não o "modelo do consumismo" e o "tecnológico".

Os apontamentos de Freud (1930/2006) sobre o sofrimento mais fácil de ser experimentado e possivelmente o mais penoso ser aquele proveniente de nosso relacionamento com outros homens e que, contra esse tipo de sofrimento, a defesa mais imediata seja o isolamento voluntário parecem ter um lugar especial nesta tese. Os participantes revelaram, por meio de seu recolhimento narcísico, que a opinião dos outros não encontra nestes um lugar significativo - fosse porque as opiniões deles eram muito mais importantes, fosse porque, ainda que a opinião dos outros contasse, a deles contava também, fosse ainda porque a opinião dos outros era invariavelmente incorreta. Portanto, um tipo de posicionamento em que o sujeito não se permite modificar, ser questionado, transformar-se e enriquecer-se frente à presença e importância do outro, mas em que, preferencialmente, procura proteger-se desse contato com o outro. Nosso entendimento é o de que há um risco grande nesse contato, como se supusessem que o contato não tendesse ao enriquecimento, mas ao dilaceramento, ao enfraquecimento. É o que notamos em algumas das construções subjetivas analisadas: sentem que perdem, na troca intersubjetiva.

Conforme observou Eiguer (2008), o apaixonado fica quase à mercê, está frágil e facilmente se coloca em questão, sem a menor objeção diante da pessoa amada. Esse tipo de vínculo, por conseguinte, expõe o sujeito de uma maneira mais ampla às opiniões do outro e supomos que é principalmente disso que procuram livrar-se, quando estabeleceram para si a opção de não ter um vínculo amoroso compromissado: de uma suposta vulnerabilidade e exposição ao outro. O voltar-se narcísico para si que apresentam evidencia uma fragilidade egoica que nos faz pensar num dilaceramento subjetivo no contato com o outro. Tudo se passa como se nossos participantes não se sentissem fortalecidos o suficiente para aceitar o que vem do outro como algo que pudesse ser realmente aproveitado em seu benefício, tudo é sentido como crítica e tem o caráter de desestruturação. A fragilidade que demonstram indica que não estão realmente convencidos de que são capazes de lidar com as dificuldades da vida, de 
aceitar críticas, resolver conflitos, pois não têm uma boa estima sobre si e as opiniões alheias são interpretadas como julgamentos capazes de destruí-los e não como possibilidades de transformação, deles e do vínculo.

Nesses casos, como explicou Eiguer (2008), quando as opiniões alheias não são levadas em conta ou são interpretadas, o vínculo que daí decorre não tem consistência e/ou passeia pelo âmbito da patologia. Para aceitarmos as opiniões alheias, é preciso não somente acreditar em nossa capacidade de lidar com aquilo que incomoda, mas acatar nossas faltas, o que requer capacidade de elaboração. Um vínculo amoroso compromissado exige isso dos parceiros: que estejam disponíveis para constantes questionamentos sobre si mesmos e sobre o outro, dando ao vínculo a sua característica viva de propiciar a transformação dos sujeitos envolvidos, mesmo que isso seja, às vezes, doloroso. Um vínculo saudável comporta a existência de conflitos.

Contudo, além da dificuldade em lidar com os conflitos próprios de um vínculo, hoje, o simples fato de esses conflitos existirem parece ser um absurdo. Os nossos participantes demonstraram isso quando, por exemplo, assumem que a pessoa amada por vezes é imaginada e esperada como uma réplica de si mesmo. Para Henrique e João Pedro, a mulher idealizada deve corresponder a suas expectativas que não passam de formas encontradas para lidar negativamente com a frustração que vem do diferente. No caso deles, ainda percebemos que a parceira é pensada como alguém que serviria para ajudar na elaboração de suas dificuldades, quase uma terapeuta. Nesse sentido, o que conjecturamos é que, imersos em uma sociedade que pouco oferece em termos de uma experiência de vida mais confortável, buscar um vínculo amoroso pode representar uma procura por esse conforto, fazendo do outro uma fonte inevitável de dor e frustrações, não somente porque precisam lidar com o diferente quando supunham que essa diferença não existia, mas também porque ambos esperam antes receber esse conforto do parceiro do que dar. Quer dizer, na atualidade, buscar um vínculo amoroso pode significar a busca, no fundo, por uma terapia.

Sentimos falta de um trabalho do pré-consciente em nossos participantes capaz de comportar e transformar elementos de angústias, as faltas, as dificuldades, os conflitos e nãosaberes próprios da existência. Em contrapartida, quando se viam diante desses elementos incômodos, mostravam-se mais propensos a utilizar mecanismos de defesa, como o isolamento, a projeção, as identificações projetivas, a cisão, a recusa e a negação. Entendemos que existia um empobrecimento de trabalho psíquico como efeito de um movimento de uma sociedade que parece estar substituindo a "assinatura" de contratos estáveis e duradouros, como assinalou Kaës (2005b), pela valorização de acordos negociáveis e que tendem a 
favorecer a imediata satisfação dos desejos. Se, num primeiro momento, esse movimento atendeu aos interesses de um sistema econômico baseado nas leis de mercado, como afirma Bauman (2001), num segundo momento, passou a atender também às necessidades de um funcionamento psíquico em que o os processos primários são soberanos, em detrimento dos secundários, conforme observou Justo (2005), em consonância com as necessidades narcísicas.

O contrato narcísico, apresentado por Kaës (2005b) como um daqueles que pode sofrer com interferência de valores externos aos da família de origem e não propiciar a manutenção do legado, pôde, em acréscimo, ser percebido dessa forma. Alguns de nossos participantes revelaram-se pouco dispostos a dar continuidade àquilo que lhes foi apresentado como importante, no seio familiar, e mais identificados com valores e mitos sociais. E esse dado é um ponto de nossas análises que aborda também o lado positivo das condições contemporâneas de existência: ou seja, a valorização da abertura para a construção do novo e para a criatividade está acima da rigidez e imposição com que eram transmitidos alguns valores, em épocas passadas. Embora isso tenha algum caráter desorganizador, porque muitos de nossos participantes sabem apenas o que não querem para o seu futuro, deu a alguns deles a possibilidade de sustentar uma subjetividade mais coerente e satisfatória.

Realmente, como aponta Bauman (2009), atualmente, as identidades parecem feitas de pedaços que podem ser rearranjados, mas aparentemente os pedaços são escolhidos de modo mais verdadeiro. É assim que, tendo "beirado o casamento" e recuado, Henrique hoje se vê mais satisfeito com a vida de solteiro do que com a vida de casado que teria, nessa etapa da vida, confirmando os achados de Davies (2003).

Existe uma complexidade que aborda o contemporâneo, o que exige um entendimento muito além de um raciocínio linear, como enfatizou Kaës (2005b), e por isso não podemos cair em deduções de que tudo leva a uma desestruturação, nem de que tudo seja benéfico. Concordamos com Lipovetsky (2004) que, embora mais autônomos, nossos contemporâneos são também mais frágeis. À medida que diminuiu o poder organizador que o coletivo tinha sobre o individual, as obrigações e as exigências que nos cercam passaram a ser mais vastas e mais pesadas. Ao mesmo tempo em que temos mais condições de estruturarmos construções mais autênticas e criativas, são igualmente mais difíceis de serem sustentadas. A citação de Goethe, retomada por Freud (1913/2006, p. 160), nunca foi tão necessária: “Aquilo que herdaste de teus pais conquista-o para fazê-lo teu".

Nesta tese, entendemos que aquilo que herdamos de nossos antecessores deve ser apropriado, levando-se em consideração o contexto sociocultural, de uma forma que faça 
sentido e ajude o indivíduo a encontrar seu lugar no mundo, a constituir-se como sujeito de sua história, dando sentido a sua existência. O que estamos enfatizando aqui é que nos parece que, neste momento histórico, essa tarefa está muito mais nas mãos de cada um, daí seu peso maior.

Patrícia mostrou, por exemplo, como pode ser custoso o trabalho de elaboração da herança psíquica geracional, quando não se pode contar com "garantias metassociais" e "metapsíquicas" (Kaës, 2005b) suficientemente estáveis. Sua história é de uma transmissão que, embora consciente, ainda é sem possibilidade de transformação. Isto quer dizer que, mesmo que sua história familiar tenha contribuído para a estruturação de seus conflitos, o modo de encará-los (mecanismos de recusa; defesas narcísicas; dificuldade de construção de vínculos; dificuldades de elaboração, de simbolização, de sustentação e transformação pulsionais etc.) está em consonância com as dificuldades psíquicas sustentadas pela organização sociocultural. Assim, é como se a sociedade possibilitasse os caminhos, as soluções de compromisso possíveis diante dos conteúdos conscientes e inconscientes de cada um.

Do mesmo modo, compreendemos que a alternativa que Gustavo encontrou para fazer em face de um espaço social de constituição subjetiva mais confiável foi criar um lugar individual, protegido do outro, para desenvolver com calma seus projetos e pensar em seu futuro. O outro, para ele, é quase incapaz de ser pensado como alguém que poderia ajudá-lo nessa tarefa, imagina-o como aquele que irá intervir e não lhe possibilitará uma construção subjetiva verdadeira. Isabella parece igualmente se referir a uma dificuldade de se diferenciar num mundo instável e "pasteurizado". Todavia, Henrique, como sublinhamos acima, observa o contrário: o quanto essa perda de referências estáveis possibilitou-lhe seguir outro caminho, no tempo e no ritmo de que precisar.

Tatiana parece contente com o modo como conseguiu se organizar: em consonância com os mitos da "individualidade", da "mulher de êxito", da "independência afetiva", e com a satisfação que encontra em uma vida preenchida por atividades e trabalhos, ela consegue obter prazer, satisfação e reconhecimento por meio de seu sucesso. O caso de João Pedro, contudo, mostra-nos a importância que teriam os valores mais consolidados, contratos mais bem estabelecidos. Ele precisa transformar o herdado de uma forma criativa, garantindo-lhe a apropriação de sua herança e a construção de um ego mais integrado, e parece ter conseguido uma base de sustentação para si sendo elo numa cadeia de transmissão da cultura japonesa.

No caminhar desta tese, algumas perguntas acompanharam o nosso trabalho de reflexões. O vínculo amoroso compromissado é necessário? Ter um vínculo amoroso 
duradouro é sinal de saúde psíquica? Isso porque tínhamos em mente o cuidado de não cair em deduções patológicas para todos os casos, como se todos estivessem nos apresentando algum tipo de mecanismo de defesa e o que precisávamos era somente mostrar como isso ocorria em cada um deles. Gustavo e Tatiana revelaram-se muito satisfeitos com a vida que levavam, embora tenhamos relativizado essa satisfação na análise dos casos. Isso quer dizer que, a despeito de termos concluído que Gustavo tenha suas razões para desconfiar de si mesmo e o vínculo pareça ser ameaçador nesse sentido, e Tatiana sofra com a falta de reconhecimento dos pais, ambos ainda pareciam, de fato, satisfeitos. Mesmo porque ter conflitos com relação a um dado posicionamento não é sinal de patologia. Ambos mostram um tipo possível de resolução, de escolha que envolve satisfação, diante das particularidades de cada história, em acordo com os trabalhos de DePaulo e Morris (2005). Tatiana, inclusive, busca encontrar um sentido para sua opção dentro de sua cadeia geracional. Patrícia, por outro lado, expõe-nos um tipo de resolução que não aponta para o lado da satisfação, mas da falta de opção. Isabella tem dúvidas quanto ao seu posicionamento quanto ao vínculo amoroso por desconfianças sobre suas possibilidades e as do outro, e também porque não está satisfeita com a escolha. Henrique parece estar vivenciando um momento de transição, mais satisfeito do que estaria em um casamento, mas o momento atual aparenta ser um estado de espera para refletir sobre as possibilidades de sua vida. E João Pedro está "fechado para balanço", porque questões de caráter mais urgentes o aguardam.

Nesse sentido, de nossas análises, cremos que esse questionamento surgido sobre a relação entre a formação de um vínculo amoroso compromissado e a saúde psíquica tenha uma resposta. Nossa intuição tenderia a dizer que sim, que manter um vínculo amoroso é sinal de capacidade de construção e elaboração, criando a possibilidade de dar prosseguimento ao legado familiar. Porém, não querer ter um vínculo amoroso compromissado não necessariamente significa ausência de saúde psíquica. Eiguer (2008), escrevendo sobre o funcionamento de um libertino, observa que sua construção é criativa e que não deve ser compreendida como patológica, como no caso do perverso, porque o libertino não se sente em dívida com ninguém. Sente-se simplesmente livre. Nenhum de nossos participantes apresentou-se assim tão livre, mas ainda sim capazes de continuar com esse posicionamento como sendo aquele que mais verdadeiramente representa suas capacidades e possibilidades, nesse momento de suas vidas.

De um modo condensado, como efeito de tudo o que foi discutido até aqui, o que nossos participantes nos mostraram é que a opção deles por não ter um vínculo amoroso compromissado representa, no fundo, uma escolha por não abrir mão de si pelo outro. Como 
efeito das condições de existência externas e de origem internas sentem-se inseguros, vulneráveis, e é como se tivessem que optar por si mesmo em detrimento do outro. A indisponibilidade psíquica para o contato com a alteridade relaciona-se a uma fragilidade narcísica em que o outro e o vínculo não podem ser vistos como fonte de satisfação, já que qualquer mero desapontamento tem um efeito de ferimento narcísico. Logo, voltaram-se para as suas carreiras, atividades, projetos, hobbies e optaram por resolver seus conflitos longe do outro, porque - e esse é o aspecto original do fenômeno -, o outro é visto como fonte ameaçadora da construção subjetiva. Não possuem esperanças de resolver questões de ordem inter ou transgeracionais, por exemplo, buscando alguém que fosse diferente do modelo dos pais. Na linguagem deles, o outro machuca, é incompreensível, destrói, atrapalha. Fechar-se narcisicamente é a saída viável, além de indicar o diferencial em relação a outras épocas, em que compartilhar a vida era o modelo: nossos contemporâneos são menos habilidosos e possuem mais dificuldades para receber o que vem do outro, de modo construtivo. Por isso, abrir mão de algo, de um pensamento, de uma academia, de uma viagem para cuidar do outro é tão perturbador: o sujeito sente-se ameaçado dentro de um raciocínio em que abrir mão de algo é quase sinônimo de abrir mão de si.

Assim, é nesse sentido que o fenômeno estudado, embora não seja novo, deve ser pensado em consonância com as condições de existência contemporâneas: ele tem relação com a fragilização com que são formados alguns vínculos, atualmente. Essa fragilidade é decorrência de como as condições de existências contemporâneas estão organizadas, tendendo a devolver o indivíduo para o interior de si, ao priorizar o pessoal em detrimento do coletivo.

Finalizando, concluímos que a opção pela não construção de um vínculo amoroso compromissado relaciona-se com conteúdos internos do psiquismo e/ou herdados geracionalmente, em consonância com um mal-estar contemporâneo, que pode ser representado por uma insegurança e um fechamento para o outro, decorrentes das condições de vida em uma sociedade em que os contratos perderam o caráter de estabilidade, podendo ser negociados e visando a atender às satisfações imediatas. 


\section{Capítulo VIII}

\section{Considerações Finais}

Escrever uma tese dentro de uma vertente qualitativa, cuja análise em profundidade foi escolhida, invariavelmente faz pensar sobre o alcance dessas conclusões e das discussões que foram possíveis de ser feitas. Não podemos sustentar que todo o conhecimento que este estudo possibilitou aconteça da mesma forma com todos os indivíduos que optam por não ter um vínculo amoroso compromissado, até porque isso jamais poderia ser afirmado, mas imaginamos que os motivos da escolha de alguma forma estabeleçam relações com o que apresentamos, na discussão. A aproximação e a reflexão possível com a singularidade dos casos é uma vertente própria dos estudos qualitativos, mas, se esse tipo de estudo não nos permite, por um lado, averiguar a dimensão social do fenômeno e estabelecer generalizações, por outro, possibilita uma compreensão mais profunda do mesmo, de suas articulações ocultas, de detalhes de sua construção, um entendimento maior acerca de sua complexidade e - por que não? - algumas conclusões.

Entretanto, neste momento, o que cabe são algumas considerações finais. Entendemos deste trabalho que as condições de existências sempre estarão presentes e farão parte do modo como se compõem as subjetividades, bem como o legado geracional. Para alguns autores, como Bauman (2001, 2004, 2007, 2009), as condições de existências atuais têm o diferencial de um "futuro sombrio", pouco esperançoso, principalmente quanto à manutenção de vínculos estáveis. No entanto, estudiosos como Lipovetsky $(2004,2005)$ defendem uma compreensão mais abrangente e percebem que há, na verdade, um paradoxo que compõe a contemporaneidade, como verificamos: há melhores possibilidades de expandir a criatividade, o diálogo e a autenticidade nas escolhas, ao mesmo tempo em que as condições psíquicas para sustentar isso parecem mais frágeis.

Ainda assim, não nos cabe afirmar nada sobre o futuro, porque inclusive tudo o que detectamos pode simplesmente representar maneiras específicas de se relacionar em um momento de transição. O que parece certo é que precisamos aprender a conviver com a alteridade, porque nossos contemporâneos são diversificados e dinâmicos. Isso requer um psiquismo flexível: elaborações constantes e estar disponível para posicionamentos diversos 
dos nossos e, por vezes, inimagináveis. Nesse panorama, o ser humano não sabe muito o que esperar do outro e isso tem implicações distintas. Uma delas, percebida em nossa tese, é que, em função dessa falta de possibilidade de controle do outro, de previsibilidade em relação ao que esperar do futuro, podemos nos sentir mais ameaçados narcisicamente, o que dificulta ainda mais o convívio.

Sem a pretensão de "fechar um diagnóstico" sobre a contemporaneidade, dada sua complexidade, conjecturamos que o mal-estar na civilização atual resulta de sofrimentos em função das exigências maiores de uma sociedade sobre os indivíduos, que apoia todo o tipo de construção subjetiva, mas as deixa ao encargo dos indivíduos. O que perdemos junto com a rigidez dos contratos foram também as referências, as bases. Se, por um lado, isso é libertador, por outro, pode ser um pouco desorganizador, sobretudo para aqueles que sofrem com valores instáveis decorrentes de uma dificuldade de poder contar consigo próprio, confiando em sua flexibilidade psíquica. Como salientou Granjon (2001), o trabalho da transmissão dos valores, dos conteúdos conscientes e inconscientes, permite que cada um não parta do "zero". Não que hoje estejamos partindo do "zero" a cada nova geração, mas a sensação de desgaste em vista de uma certa "orfandade" de referências pode ser um pouco essa.

Contudo, ao mesmo tempo em que os vínculos se encontram mais preenchidos por valores passíveis de serem questionados e requestionados por seus membros e isso traga insegurança, trata-se da possibilidade da abertura para o diálogo e para pensar os conflitos. Novamente, um paradoxo e a complexidade a que estamos expostos. Se antigamente os vínculos eram mais estáveis, eram igualmente pouco abertos para o diálogo: os conflitos existiam, mas dificilmente podiam ser questionados/conversados. Atualmente, com o advento do "relacionamento puro" (Giddens, 2007), valorizamos a igualdade de direitos e de responsabilidade, o respeito mútuo e a presença do diálogo aberto no vínculo, embora aparentemente as condições de mantê-lo sejam mais frágeis.

Imaginávamos, ao escrever a fundamentação teórica desta tese, que as mesmas características que tornam os vínculos mais democráticos, hoje em dia, seriam também a fonte da fragilidade em alguns vínculos, por trazer o incômodo da instabilidade. Como investir no vínculo, se mal conheço o meu parceiro e, sabendo que hoje em dia as pessoas tendem a mudar de valores, de crenças e mesmo da ideia de continuar a investir no vínculo, diante do menor dos obstáculos? O que compreendemos é que a instabilidade dos contratos afeta a estabilidade dos vínculos, porque interfere na esperança dos parceiros de se manterem sempre unidos, como se pensava antigamente, além de o sentimento de vulnerabilidade narcísica 
decorrente da instabilidade interferir na capacidade de mediação dos conflitos e de aceitar as próprias faltas. Isto é, diante da ausência de contratos sólidos sustentando a formação dos vínculos, supomos que serão cada vez mais os próprios indivíduos os responsáveis pela manutenção do mesmo, com o agravante de que o cenário contemporâneo também não disponibiliza bases para o bom funcionamento do pré-consciente, para a elaboração da falta. Em outras palavras, na atualidade, dependemos mais da internalização de objetos bons e confiáveis ao longo da vida, a fim de nos ajudar a continuar a apostar e investir nos vínculos, a ter esperança nessa construção. Sem essa base interna muito bem estruturada, será mais fácil resolver os conflitos mantendo a idealização e rompendo os laços, já que desistem do vínculo em face de uma não esperança internalizada de que irá se manter, e de uma necessidade de se proteger dos conflitos.

Aparentemente, este estudo nos abriria a perspectiva de pensar sobre o futuro da família em função da fragilidade com que são formados os vínculos, atualmente. Dentro da perspectiva desta tese, cabe questionar: a família como instituição sobreviveria, se formada por vínculos pouco (ou nada) duradouros? Henrique, em certa altura de seu relato, diz que fazer um filho é fácil, "tem gente para isso disponível no mercado, mas criar já é outra coisa". Por enquanto, o que temos visto a esse respeito é um aumento significativo de divórcios e famílias reconstituídas. Uma intolerância maior, supomos, com relação às dificuldades características do vínculo. Nesse sentido, este trabalho fez pensar que a reconfiguração das famílias, própria da contemporaneidade, não se deva somente pelo fato de nossas condições de existência permitirem possibilidades impensáveis em outras épocas. Ou seja, há possivelmente uma vertente que sustenta esse fenômeno e se relaciona com a dificuldade de nossos contemporâneos em lidar com a frustração, mediar os conflitos, ter esperanças de chegar a um consenso e da manutenção do vínculo. Abrir mão de algo, de um pensamento, de qualquer coisa, visando a favorecer o desenvolvimento do vínculo, pode não fazer sentido numa sociedade onde todos se sentem frágeis, narcisicamente falando. Dessa forma, a reconfiguração das famílias se sustentaria igualmente na teoria kaesiana que entende a dificuldade de se construir vínculos estáveis e estruturados enquanto falhas em torno das "garantias metassociais" e "metapsíquicas". Isso, contudo, é uma conjectura que poderia ser mais profundamente estudada em futura pesquisa.

Outro estudo interessante seria investigar se os vínculos que, na atualidade, se mantêm estáveis e saudáveis por mais tempo se relacionam com a capacidade dos parceiros em acreditar na manutenção do mesmo, envolvendo a possibilidade de mediação dos conflitos, a esperança de chegar a um consenso e de aceitar as próprias faltas. Quando "bons objetos 
internalizados" de certa forma garantem uma sustentação do vínculo, cumprindo com a função de referências externas confiáveis e duradouras de outras épocas. Ou, então, se ainda hoje os vínculos que verificamos se manter por mais tempo e de forma saudável se sustentam em vista de valores tradicionais, por exemplo.

Além disso, pareceu ainda que parte dos conflitos e dificuldades de elaborá-los, hoje em dia, no vínculo amoroso deve-se pela busca de encontrar no outro aquilo que não encontramos mais num nível sociocultural, condições mais favoráveis de desenvolvimento. Possivelmente, essa busca sempre deva ocorrer, mas para que seja possível esse tipo de encontro é importante a aceitação de que não nos bastamos. O que queremos dizer é que, quando se procura por esse conforto no vínculo, sem a noção de que somos falhos e precisamos do outro, em muitos aspectos da vida - em outras palavras, aceitando a possibilidade da dependência, sem se sentir ameaçados por ela -, no fundo, o que buscamos é que o outro nos preencha e seja exato nessa medida. O outro, dentro desse viés, não pode ser concebido plenamente em sua existência. A dificuldade de aceitar a alteridade, de imaginar que o outro seja passível de falha, que possua necessidades diferenciadas, parecem ser características de nossa época.

Finalizando a tese, cremos que vale ressaltar que não sabemos qual será a continuidade da história de nossos participantes: não podemos supor se irão manter essa opção pelo resto de suas vidas ou se, no momento do término desta tese, já a reconsideraram e estão namorando. Inclusive, porque foi nítido o quanto para muitos a entrevista possibilitou um contato com essa temática que os fez refletir mais sobre o assunto. Destacamos, por isso, a importância da consciência do pesquisador-psicólogo sobre o nível de mobilização que uma entrevista como essa pode causar e do papel ético, enquanto profissional, de possibilitar uma conversa posterior ou mesmo uma devolutiva.

Gostaríamos, por fim, de agradecer a participação de nossos companheiros de tese, que, a partir do momento em que passaram a ser Patrícia, Gustavo, Isabella, Henrique, João Pedro e Tatiana, também deixavam de ser quem são, em suas vidas reais. Com essa ressalva, queremos enfatizar que em nenhum momento seríamos capazes de defender nossa vertente interpretativa de suas histórias como a única ou como aquela que melhor os representa. Suas vidas certamente ultrapassam em muito nossas construções, ainda que tenham nos oferecido a oportunidade de escrever uma tese rica em experiências subjetivas.

O que puderam nos proporcionar (e nossa pretensão) era nada além da construção de um texto com sentido, que nos ajudou a entender um fenômeno contemporâneo, porém, que jamais poderá abarcar toda a complexidade de um sujeito. Dependemos desses relatos de vida 
para dar continuidade a nossas pesquisas, e confiamos numa escuta que buscou, acima de tudo, a todo o momento olhar para uma experiência de vida, para um tipo de escolha, e contextualizá-la neste momento histórico. Por isso, desejamos que esta tese possa ser lida desta forma: como mais uma contribuição para pensarmos o sentido de nossas existências. 
Capítulo IX

Referências ${ }^{35}$

Aberastury, A. (1987). Psicanálise da Criança. Porto Alegre: Artes Médicas.

Agrapart-Delmas, M. (2009). La criminalité féminine intrafamiliale. In M. Agrapart-Delmas, Femmes Fatales (pp. 163-194). Paris: Max Milo.

Antunes, M. S. X. (2010). Itinerários da vida de solteira: razões e sentidos em projetos de vida de mulheres solteiras à luz do sintagma Identidade-Metamorfose-Emancipação. Dissertação de Mestrado em Psicologia Social, Pontifícia Universidade Católica de São Paulo, São Paulo.

Arendt, H. (2009). Entre o passado e o futuro. São Paulo: Perspectiva.

Armony, N. (2009). Confrontando Winnicott com os azares da hipermodernidade. Cadernos de Psicanálise SPCRJ, 25 (28), 77-119.

Aulagnier, P. (1979). A violência da interpretação. Rio de Janeiro: Imago.

Baptista, M. N. (2007). Metodologias de Pesquisa em Ciências: análises quantitativa e qualitativa. Rio de Janeiro: LTC.

Baroncelli, L. (2011). Amor e Ciúme na Contemporaneidade: reflexões psicossociológicas. Psicologia \& Sociedade; 23 (1), 163-170.

Baudrillard, J. (1993). Cultura y Simulacro. Madrid: Kairós. . (2007). A Sociedade de Consumo. Lisboa: Edições 70.

Bauman, Z. (2001). Modernidade Líquida. Rio de Janeiro: Jorge Zahar Editor.

${ }^{35}$ De acordo com o estilo APA - American Psychological Association 
. (2004). Amor Líquido: sobre a fragilidade dos laços contemporâneos. Rio de Janeiro: Jorge Zahar Editor.

_ (2007). Tempos Líquidos. Rio de Janeiro: Jorge Zahar Editor.

(2008). Vida para Consumo. Rio de Janeiro: Jorge Zahar Editor.

. (2009). Vida Líquida. Rio de Janeiro: Jorge Zahar Editor.

Benjamin, J. (1988-1992). Les liens de l'amour. Paris: Métaillié.

. (1998). Shadow of the Other: intersubjectivy and Gender in Psychoanalysis. New York: Routledge.

Berenstein, I. \& Puget, J. (1993). Psicanálise do Casal. Porto Alegre: Artes Médicas.

Berger, P., \& Luckmann, T.A. (2002). A construção social da realidade. Tratado de sociologia do conhecimento. Rio de Janeiro: Vozes.

Bion, W. R. (1970). Experiências com grupos. Rio de Janeiro: imago.

Birman, J. (2011). Mal-estar na atualidade: a psicanálise e as novas formas de subjetividade. Rio de Janeiro: Civilização Brasileira.

Bleger, J. (1980). A entrevista psicológica. In J. Bleger, Temas de psicologia: entrevista e grupo (pp. 7-44). São Paulo: Martins Fontes.

Bourdieu, P. (1982). A Economia das Trocas Simbólicas. São Paulo: Editora Perspectiva.

Byrne, A. \& Carr, D. (2005). Caught in the Cultural Lag: The Stigma of Singlehood. Psychological-Inquiry. 16(2-3), 84-91.

Campos, L. F. de L. (2004). Métodos e Técnicas de Pesquisa em Psicologia. Campinas: Alínea. 
Carneiro, M. J. (1987). A desagradável família de Nelson Rodrigues. In S. A Figueira (Org.), Uma Nova Família? O moderno e o arcaico na família de classe média brasileira (pp. 69-82). Rio de Janeiro: Jorge Zahar Editor.

Castoriadis-Aulagnier, P. (1975). La violence de l'interprétation. Le pictogramme et l'énoncé. Paris: PUF.

Charles, S. (2004). O individualismo paradoxal: introdução ao pensamento de Gilles Lipovetsky. In G. Lipovetsky, Os tempos Hipermodernos (pp. 13-48). São Paulo: Editora Barcarolla.

Chasteen, A. L. (1994). The world around me - the environment and single women. Sex Roles, 31 (5-6), 309-328.

Coelho Junior, N. E. \& Figueiredo, L. M. C. (2004, janeiro/junho). Figuras da Intersubjetividade na Constituição Subjetiva: dimensões da alteridade. Interações, São Paulo, IX(17), 09-28.

Costa, J. F. (2003). Violência e Psicanálise. Rio de Janeiro: Edições Graal.

Davies L. (2003). Singlehood: Transitions within a gendered world. Canadian Journal on aging-revue canadienne du Vieillissement, 22 (4), 343-352.

DePaulo, B. \& Morris, W. (2005). Singles in Society and in Science. Psychological-Inquiry, 6(2-3), 57-83.

. (2006, octobre). The Unrecognized Stereotyping and Discrimination Against Singles. Current-Directions-in-Psychological-Science, 15(5), 251-254.

Dolto, F. (1980). Psicanálise e Pediatria. Rio de Janeiro: Zahar Editores.

Eiguer, A. (2008). Jamais moi sans toi. Paris : Dunod.

. (2009). Les mythes de la famille et du thérapeute familial et leur déconstruction. Le Carnet PSY, 3 (134), 31-35. (2010). Psychanalyse du Libertain. Paris: Dunod. 
. (2011). Le sens de la famille, le nous et le lien. Cahiers critiques de thérapie familiale et de pratiques de réseaux, 47, 39-52

Fassin, D. (2006) Du déni à la dénégation. Psychologie politique de la représentation des discriminations. In E. Fassin \& D. Fassin, De la question sociale à la question raciale? (pp. 131-157). Paris: Éditions La Découverte.

Féres-Carneiro, T. (2005). Conjugalidade dos Pais: possíveis influências no projeto de casamento dos filhos. In Simpósio Nacional de Psicologia Social e do Desenvolvimento $\mathrm{X}$ Encontro Nacional PROCAD-Psicologia/CAPES. Violência e Desenvolvimento Humano: Textos Completos, (pp. 89-97).

Fernandes, M. I. A. (2003). O Trabalho psíquico da intersubjetividade. Psicologia USP, $14(3), 47-55$.

(2004). Algumas reflexões sobre a negatividade na construção dos laços sociais [Versão eletrônica]. Vínculo, 1 (1), 9-16.

Freud, S. (1900-2006). A interpretação dos Sonhos. Edição Standard Brasileira das Obras Psicológicas Completas de S. Freud, Vol. IV e V. Rio de Janeiro: Imago.

(1905-2006). Três ensaios sobre a teoria psicanalítica. In S. Freud, Um caso de Histeria, Três Ensaios sobre Sexualidade e outros trabalhos (1901-105). Edição Standard Brasileira das Obras Psicológicas Completas de S. Freud, Vol. VII (pp. 119-217). Rio de Janeiro: Imago.

(1910-2006). Cinco Lições de Psicanálise. In S. Freud, Cinco Lições de Psicanálise, Leonardo da Vinci e outros trabalhos. Edição Standard Brasileira das Obras Psicológicas Completas de S. Freud, Vol. XI (pp. 17-65). Rio de Janeiro: Imago.

(1913-2006). Totem e Tabu. In S. Freud, Totem e Tabu e outros trabalhos (19131914). Edição Standard Brasileira das Obras Psicológicas Completas de S. Freud, Vol. XIII (pp. 13-163). Rio de Janeiro: Imago.

(1914-2006). Sobre o Narcisismo: uma introdução. In S. Freud, A história do movimento psicanalítico, artigos sobre a metapsicologia e outros trabalhos. Vol. XIV. Edição Standard Brasileira das Obras Psicológicas Completas de S. Freud (pp. 77-108). Rio de Janeiro: Imago. 
(1915/1916-2006). Conferencia XIX: Resistência e Repressão. In S. Freud, Conferências Introdutórias sobre a psicanálise. Parte III (1915-1916). Edição Standard Brasileira das Obras Psicológicas Completas de S. Freud, Vol. XVI (pp. 293-308). Rio de Janeiro: Imago.

(1916-2006). Conferência XXVII: Transferência. In S. Freud, Conferências Introdutórias sobre a psicanálise. Parte III (1915-1916). Edição Standard Brasileira das Obras Psicológicas Completas de S. Freud Vol. XVI. (pp. 433-463). Rio de Janeiro: Imago.

(1917-2006). Luto e Melancolia. In S. Freud, A História do Movimento Psicanalítico, Artigos sobre Metapsicologia e outros trabalhos (1914-1916). Edição Standard Brasileira das Obras Psicológicas Completas de S. Freud Vol. XIV, (pp. 245-263). Rio de Janeiro: Imago.

(1920-2006). Além do Princípio do Prazer. In S. Freud, Além do princípio de prazer psicologia de grupo e outros trabalhos. Edição Standard Brasileira das Obras Psicológicas Completas de S. Freud Vol. XVIII, (pp. 13-75). Rio de Janeiro: Imago.

. (1921-2006). Psicologia de Grupo e a Análise do Ego. In S. Freud, Além do princípio de prazer psicologia de grupo e outros trabalhos. Edição Standard Brasileira das Obras Psicológicas Completas de S. Freud Vol. XVIII, (pp. 79-154). Rio de Janeiro: Imago.

(1922-2006). Alguns mecanismos neuróticos no ciúme, na paranoia e no homossexualismo. In S. Freud, Além do Princípio do Prazer, Psicologia de Grupo e outros trabalhos (1920-1922). Edição Standard Brasileira das Obras Psicológicas Completas de S. Freud Vol. XVIII, (pp. 234-247). Rio de Janeiro: Imago.

(1924-1969). A Dissolução do Complexo de Édipo. In S. Freud, O Ego o Id e outros trabalhos. Edição Standard Brasileira das Obras Psicológicas Completas de S. Freud, Vol. XIX (pp. 191-199). Rio de Janeiro: Imago.

(1930-2006). O mal-estar na civilização. In S. Freud, O futuro de uma ilusão o malestar na civilização e outros trabalhos. Edição Standard Brasileira das Obras Psicológicas Completas de S. Freud, Vol. XXI (pp. 67-148). Rio de Janeiro: Imago.

(1932-2006). Feminilidade. In S. Freud, Novas Conferências Introdutórias sobre Psicanálise e outros trabalhos. Edição Standard Brasileira das Obras Psicológicas Completas de S. Freud, Vol. XXII (pp. 113-134). Rio de Janeiro: Imago. 
Frosh, S. (2009). O Lugar da Psicanálise no Campo da Psicologia Social. Aulas ministradas no Instituto de Psicologia nos dias 25 e 27 de agosto, 01, 03 e 04 de setembro de 2009.

Giddens, A. (1991). As conseqüências da modernidade. São Paulo: Unesp.

. (2007). Mundo em Descontrole: o que a globalização está fazendo de nós. Rio de Janeiro: Record.

Gomes, I. C. (2009). Famílias Reconstituídas: um Novo Desafio para a clínica contemporânea. In I. C. Gomes (Org.), Clínica Psicanalítica de Casal e Família: a interface com os estudos psicossociais. (pp. 33-39). São Paulo: Editora Santos.

Gomes, L. G. N. \& Silva Junior, N. (2007). Sobre a amizade em tempos de solidão. Psicologia \& Sociedade, 19 (2), 57-64.

Granjon, E. (2001). A elaboração do tempo genealógico no espaço do tratamento da terapia familiar psicanalítica In O. B. R. Correa (Org.), Os avatares da transmissão psíquica geracional (pp. 17-43). São Paulo: Editora Escuta.

Haesler, L. (1992). De la transmission transgénérationnelle du traumatisme. Journal de la Psychanalyse de L'enfant, 9, 132-147.

Hegel, G. W. (1807-1998). La Phénoménologie du moi et le problème de l'adaptation. Paris: PUF.

Heidegger, M. (1927-1962). Being and Time. Oxford, UK: Basil Blackwell. Translation John Macquarrie and Edward Robinson.

Honneth, A. (1992-2000). La lutte pour la reconnaissance. Paris: Cerf.

Hostetler, A. J. (2009). Single by Choice? Assessing and Understanding Voluntary Singlehood Among Mature Gay Men. Journal of Homosexuality, 56 (4), 499-531.

Husserl, E. (1929-1969). Méditations Cartésiennes. Paris: Vrin.

IBGE. Instituto Brasileiro de Geografia e Estatísticas (2010). Recuperado em 15 de dezembro de 2011, de http://www.ibge.gov.br/home/estatistica/populacao/registrocivil/2010/casamentos.shtm 
Jablonski, B. (2005). Atitudes de jovens solteiros frente à família e ao casamento: novas tendências? In T. Féres-Carneiro (Org.), A Família e o casal: efeitos da contemporaneidade (pp. 93-110). Rio de Janeiro: Editora PUC-Rio.

Jaroslavsky, E. A. \& Morosini, I. (2010). Sufrimiento vincular y sus transformaciones en el psicoanálisis de pareja y familia. Trabajo sobre el Vínculo. Mesa Redonda. Sesión Especial. In IV ${ }^{\circ}$ Congreso AIPCF 2010 (Buenos Aires-Argentina).

Jordão, A. A. (2011). Narcisismo: do ressentimento à certeza de si. Curitiba, Jaruá.

Jordão, C. \& Loes, J. (2009). Eu quero ficar sozinho. Revista Isto é. Recuperado em 3 de dezembro de 2009, de http://www.terra.com.br/istoe/edicoes/2085/artigo154639-1.htm.

Justo, J. S. (2005, janeiro/junho). O "ficar" na adolescência e paradigmas de relacionamento amoroso da contemporaneidade. Revista do Departamento de Psicologia - UFF, 17(1), 61-77.

Kaës, R. (1991). El Pacto Denegativo en los conjuntos trans-subjetivos. In A. Misseranrd et al, Lo negativo. Figuras y Modalidades. Buenos Aires: Amorrortu.

. (1993). Transmission de la vie psychique entre générations. Paris: Dunod.

(1997). O grupo e o sujeito do grupo: elementos para uma teoria psicanalítica do grupo. São Paulo: Casa do Psicólogo.

(2001). O sujeito da herança. In R. Kaës; H. Faimberg et al. (Orgs.), Transmissão da vida psíquica entre gerações (pp. 9-25). São Paulo: Casa do Psicólogo.

. (2005a). Espaços Psíquicos Compartilhados: transmissão e negatividade. São Paulo: Casa do Psicólogo.

. (2005b). La structuration de la psyché dans le malaise du monde moderne. Etudes, recherches, actions en santé mentale en Europe, 1, 239-256.

. (2009). La transmission de la vie psychique et les contradictions de la modernité. In M. Sassolas, Transmissions et soins psychiques (pp. 21-35). Paris: Hors collection. 
. (2011). Um singular plural: a psicanálise à prova do grupo. São Paulo: Edições Loyola.

Kaiser, C. \& Kashy, D (2005). The Contextual Nature and Function of Singlism. Psychological-Inquiry. 16(2-3), 122-126.

Klein, M. (1946-1991). Notas sobre alguns mecanismos esquizóides. In M. Klein. Obras Completas. V. 3 (pp. 17-43). Rio de Janeiro: Imago.

Langendorff, F. (2007). Individu, culture et societé : sensibilisation aux sciences humaines. Paris: Publibook.

Laplanche, J. (2004). Vocabulário de Psicanálise. Laplanche e Pontalis. São Paulo: Martins Fontes.

Lasch, C. (1983). A Cultura do Narcisismo. Rio de Janeiro: Imago.

Leontiev, A. N. (1978). Actividad, conciencia y personalidad. Buenos Aires: Ediciones Ciências del Hombre.

Lévinas, E. (1974). Autrement q'être ou au-delá de l'essence. La Haye: Nijhoff.

Levine, H. B. (1982). Toward a psychoanalytical undertanding of children of survivors of Holocaust. Psychoanalytical Quarterly, LI, 70-92.

Linton, R. (1999). Le fondement culturel de la personalité. Paris: Dunod.

Lipovetsky, G. (2004). Os Tempos Hipermodernos. São Paulo: Editora Barcarolla. (2005). A Era do Vazio: ensaios sobre o individualismo contemporâneo. São Paulo: Manole.

. (2007). Império do Efêmero: a moda e seu destino nas sociedades modernas. São Paulo: Companhia das Letras. 
Loncan, A. (2004). De la bisexualité psychique à l'homoparentalité. Le Divan Familial, 13, $13-28$.

Losso, R. \& Losso, A. P. (2010). Sufrimiento en las familias: viejos y nuevos mitos. Mitos familiares y mitos sociales. Un desafio para los analistas de pareja e familia. Texto apresentado no IV Congreso Internacional de Psicoanálisis de Familia y Pareja Buenos Aires, 28 al 31 de julio 2010.

Lyotard, J-F. (2008). A condição pós-moderna. Rio de Janeiro: José Olympio.

Magalhães, A. S. \& Féres-Carneiro, T. (2004/dezembro). Transmissão psíquico-geracional na contemporaneidade. Psicologia em Revista, Belo Horizonte, 10 (6), 243-255.

Mannoni, M. (1986). Primeira Entrevista em Psicanálise. Rio de Janeiro: Campus.

Mead, G. H. (1910/1978). What social objects must psychology presupose?. In T. Luckmann (Ed), Phenomenology and Sociology. Harmondsworth, UK: Penguin Books.

Merleau-Ponty, M. (1964). Le Visible et L'invisible. Paris: Gallimard.

Moguillansky, R. (1999). Vínculo y Relación de Objeto. Buenos Aires: Editora Polemos S. A.

Moguillansky, R. \& Nussbaum, S. (2009). Las familias posmodernas. In R. Moguillansky \& S. Nussbaum (Orgs), Seminario de Teoría y Clínica Vincular. (pp. 1-24). Argentina: Apdeba.

Ogden, T. H. (1996). Os Sujeitos da Psicanálise. São Paulo: Casa do Psicólogo.

Passos, M. C. (2007, novembro). A constituição dos laços na família em tempos de individualismo. Mental, 5(9), 117-130.

Puget, J. (2000). Disso não se fala... Transmissão e Memória. In O. R. Correa (Org.), Os avatares da transmissão psíquica geracional (pp. 73-87). São Paulo: Escuta.

Puget, J. ; Kaës, R et al. (1989). Violence d'État et psychanalyse. Paris: Dunod. 
Rios, I. C. (2008, abril/junho). O amor nos tempos de Narciso. Interface- Comunicação, Saúde e Educação, 12 (25), 421-426.

Robion, J. (2003). De la transmission psychique préconsciente à la transmission psychique inconsciente. Dialogue - Recherches cliniques et sociologiques sur le couple et la famille, 161(3), 5-14.

Rode, R. (2010). Solteiro, sim, e muito feliz. Recuperado em 15 de agosto de 2010, de http://estilo.uol.com.br/comportamento/ultnot/2010/08/15/solteiro-sim-e-muito-feliz.jhtm

Roudinesco, E. (2003). A Família em Desordem. Rio de Janeiro: Jorge Zahar Editor.

Sá, R. N.; Mattar, C. M. \& Rodrigues, J. T. (2006, julho/dezembro). Solidão e Relações Afetivas na era da técnica. Revista do Departamento de Psicologia - UFF, 18(2), 111124.

Safra, G. (1993). O uso do Material Clínico na pesquisa Psicanalítica. In M. E. Lino da Silva (Org..), Investigação e Psicanálise (pp. 119-132). São Paulo: Papirus.

Salles, L. M. F. (2005, janeiro/março). Infância e adolescência na sociedade contemporânea: alguns apontamentos. Estudos de Psicologia (Campinas), 22 (1), 33-41.

Santona, A. \& Zavattini, G. C. (2005). Ni avec toi ni sans toi. Le Divan Familial. 14, 39-45.

Schachner, D. A.; Shaver, P. R. \& Gillath, O. (2008). Attachment style and long-term singlehood. Personal Relationships, 15, 479-491.

Schacht, L. (1977). Découverte de l'historicité. Nouvelle revue de psychanalyse. 15, 69-79.

Scheler, M. (1923/1971). Nature et Formes de la Sympathie. Paris: Payot.

Sekeff, G. (2006). Com diploma, sem marido. Revista Veja. Edição Especial Mulher, 05/2006. Recuperado em 22 de março de 2020, de http://veja.abril.com.br/especiais/mulher_2006/p_034.html.

Sennett, R. (2008). A corrosão do caráter: consequências pessoais do trabalho no novo capitalismo. Rio de Janeiro: Record. 
Silveira, P. G. \& Wagner, A. (2006, outubro/dezembro). Ninho cheio: a permanência do adulto jovem em sua família de origem. Estudos de Psicologia. Campinas. 23(4), 441453.

Stern, J. (1986). Quarante ans après à Beer-Scheba. In P. Fédid, J. Guyotat et al, Mémoires, transferts. Paris : Ècho-Centurion.

Tavoillot, P-H. (2004). Préfacio. In G. Lipovetsky, Os tempos Hipermodernos (pp. 7-9). São Paulo: Editora Barcarolla.

Tisseron, S. (2008). Virtuel, mon amour: penser, aimer, souffrir á l'ère des nouvelles technologies. Paris: Albin Michel.

Trachtenberg, A. R. C. (2005a). Trauma, Transgeracionalidade e Intergeracionalidade: uma transformação possível. In A. R. C. Trachtenberg et al, Transgeracionalidade: de escravo a herdeiro: um destino entre gerações (pp. 119-129). São Paulo: Casa do Psicólogo.

Trachtenberg A. R. C. et al (2005b). Transgeracionalidade: de escravo a herdeiro: um destino entre gerações. São Paulo: Casa do Psicólogo.

Turato, E. R. (2003). Tratado da metodologia da pesquisa clínico-qualitativa. Petrópolis: Vozes.

Vattimo, G (2003). Posmodernidad: ¿Una sociedad transparente? In G. Vatimo; J. M. Mardones; J. Urdanibia; M. F. Riesgo; M. Maffesoli; F. Savater; J. Beriain; P. Lanceros \& A. Ortiz-Osés (Orgs). En torno a la posmodernidad (pp. 9-20). Barcelona: Anthropos Editorial.

Velho, G. (1986). Subjetividade e Sociedade: uma experiência de geração. Rio de Janeiro: Jorge Zahar Editor.

Vygotsky, L.S. (1993). Pensamento e linguagem. São Paulo: Martins Fontes.

Williams, K.; Nida, S. (2005). Obliviously Ostracizing Singles. Psychological-Inquiry. 16(23), 127-131.

Winnicott, D. W. (1975). O Brincar e a Realidade. Rio de Janeiro: Imago. 
Zanetti, S. A S. (2008). Efeitos da Fragilização dos Papéis Parentais em determinados comportamentos de crianças no ambiente escolar, na contemporaneidade. Dissertação de Mestrado, Instituto de Psicologia da Universidade de São Paulo, São Paulo.

Zimerman, D. E (2004). Manual da Técnica Psicanalítica: uma re-visão. Porto Alegre: Artmed. 


\section{Anexo A}

\section{Termo de Consentimento}

Você está sendo convidado(a) a participar de uma pesquisa de doutorado da Universidade de São Paulo.

A pesquisa se refere à sua história de vida diante do processo de escolha por ter ou não um parceiro amoroso. A sua participação será através de uma entrevista realizada com a pesquisadora, que poderá ser realizada em dois encontros, se necessário, ambos com no máximo duas horas de duração. Esta pesquisa tem por objetivo encontrar relações entre estilos de vida na contemporaneidade e a escolha por permanecer solteiro. A entrevista será gravada mediante sua autorização, através deste termo.

Informamos que a participação não é obrigatória, não haverá qualquer despesa para participar desta pesquisa, o consentimento poderá ser retirado a qualquer momento e que possui a liberdade de recusar a responder qualquer pergunta que o(a) desagrade. Gostaríamos de ressaltar que o consentimento de participação para esta pesquisa fornecerá informações importantes para o avanço no campo das ciências em psicologia.

Declaramos, ainda, o nosso compromisso com o Código de Ética Profissional do Psicólogo assegurando que os dados coletados serão mantidos em sigilo, ou seja, a publicação não incluirá informações que permitam qualquer identificação.

Em caso de dúvidas, o(a) senhor(a) poderá solicitar informações com a responsável pela pesquisa- Sandra Aparecida Serra Zanetti (CRP 06/83729) - a qualquer momento, pelo endereço eletrônico sandra.zanetti@gmail.com; ou através do "Departamento de Psicologia Clínica" do Instituto de Psicologia da Universidade de São Paulo, localizado na Av. Prof. Mello Moraes, 1721, bloco F, CEP 05508-030, Cidade Universitária, São Paulo - Telefone: (11) 3091-4173; ou ainda através do "Comitê de Ética em Pesquisa com Seres Humanos no IPUSP” - Av. Mello de Moraes, 1721 - Bloco G, sala 22 - Cidade Universitária, São Paulo SP. Telefone: (11) 3097-0529 -, ao qual esta pesquisa foi submetida e aprovada.

Respeitando, portanto, o procedimento de padrão ético em pesquisa, pedimos que autorize sua participação, assinando esse termo de consentimento.

$\mathrm{Eu}$,

informado(a) dos objetivos da pesquisa acima e certificado(a) de que os dados coletados serão confidenciais e que poderei optar pela retirada do consentimento a qualquer momento da pesquisa, autorizo a participação de meus dados na pesquisa.

São Paulo, de de 20 


\section{Anexo B \\ Parecer do Comitê de Ética}
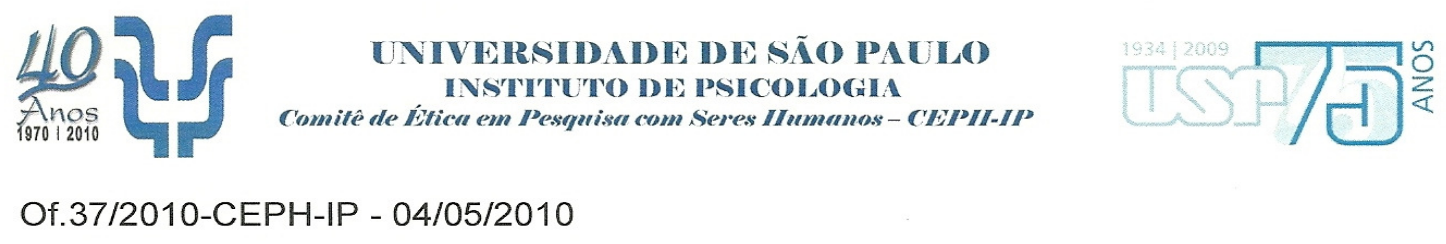

Senhora Professora,

O Comitê de Ética em Pesquisa com Seres Humanos do IPUSP (CEPHIP) em reunião de 03.05.2010 aprovou, conforme parecer anexo, o Projeto de Pesquisa $n^{\circ}$ 2009.058, intitulado: "Efeitos da fragilização dos vínculos intersubjetivos na contemporaneidade: solteiros por "opção", a ser desenvolvido por sua orientanda Sandra Aparecida Serra Zanetti, nível Doutorado, no Programa de Pós-Graduação em Psicologia Clínica do IPUSP.

Atenciosamente,

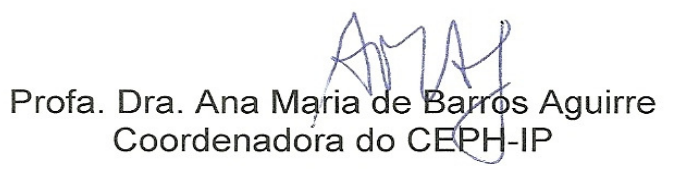

Ilma. Sra.

Profa. Isabel Cristina Gomes

Programa de Pós-Graduação em Psicologia Clínica IPUSP 


\section{Anexo $C$}

\section{Roteiro de Entrevista: "Solteiros por Opção"}

\section{$\underline{\text { Instruções }}$}

O roteiro é composto por questões que se referem à forma como adultos concebem suas histórias de vida diante do processo de escolha por não um parceiro amoroso.

O roteiro de entrevista está dividido em quatro partes: dados gerais, informações sobre a dinâmica familiar, construção da subjetividade e motivações diante da escolha por permanecer solteiro As questões serão realizadas pela pesquisadora e o participante poderá responder livremente. A entrevista será gravada e os dados pessoais serão mantidos em sigilo.

Antes de iniciar esta entrevista, será necessário que assine o termo de consentimento.

\section{Primeira Parte: Dados Gerais}

Data de aplicação do questionário: 1)

1)Horário de início:

2) Horário de início:

1)Horário de término:

2) Horário de término:

2)

1

Endereço:

Nome Completo:

Data de nascimento . Idade: anos meses. Sexo:

Número total de pessoas com quem vivem em casa:

Profissão:

Estado civil:

Duração do último relacionamento:

Idade do Pai: Idade da Mãe: Grau de Escolaridade dos Pais:

Profissões:

Segunda Parte: A Dinâmica Familiar

1- História do Participante:
a) Você poderia me contar a sua história de vida?
b) Quais os eventos que considera os mais marcantes?
c) Teve algum problema ou dificuldade que considera importante?
d) Quais as conquistas em sua história das quais sente orgulho?

2- Relação com o Legado Familiar:

a) O que você acha da vida que seus pais construíram? Por quê?

b) Como avalia o casamento de seus pais?

c) Quais os valores da educação que recebeu que considera importante e que interferiram na sua formação? Por quê?

d) O que você discorda no modo como foi educado ou no modo como seus pais constituíram o relacionamento deles? Por quê?

e) Tem algo na história de seus pais, algum evento ou postura, em que procuraria ser diferente? Em quais acha que faria igual? Por quê?

3- Lugar que ocupa na família e o tipo de relação que tem com os pais:

a) Como considera sua inserção em sua família? A relação que tem com seus irmãos?

b) Como avalia a relação que tem com seu pai? Tem alguma crítica sobre ele? Algum elogio ao modo dele se comportar com os outros e/ou com você? O que gosta e não gosta nele?

c) Como avalia a relação que tem com sua mãe? Tem alguma crítica sobre ela? Algum elogio ao modo dela se comportar com os outros e/ou com você? O que gosta e não gosta nela? 


\section{Terceira Parte: Construção da Subjetividade}

1- Relação estabelecida com Valores:

a. Quais valores você considera serem os mais importantes para você?

b. Qual deles você considera ser o mais importante?

c. Qual deles você considera importante de ter pensando em seu futuro?

d. Quais valores você considera serem os menos importantes para você?

2- Formação da identidade e relação desta com as figuras parentais:

a. Quais os valores você considera que seus pais possuem?

b. Você se identifica com alguns deles?

c. Você sente que se identifica com seus pais?

d. Como você definiria sua personalidade?

e. Quais as coisas que gosta e de que não gosta em você?

3- Grau de Confiança:

a. Você confia nas pessoas de sua família?

b. Nos seus amigos?

c. Confia no fato de que permanecerá com seu emprego e/ou nas condições de vida que possui? Por quê?

d. O que acha das condições de existência na sociedade de hoje em dia? Por quê?

e. Considera estas condições melhore sou piores do que antigamente? Por quê?

4- Relação com as atividades/ hábitos:

a. Qual a importância da sua profissão para você?

b. Qual a importância do seu trabalho? Quantas horas por dia se dedica a ele?

c. Você gosta do seu trabalho? E da sua profissão? Por quê?

d. Você realiza outras atividades durante a semana e no final de semana? Quais?

e. Você tem algum hobby?

f. Gosta de fazer compras, ir a shoppings? Com que frequência?

g. Quais os seus hábitos cotidianos?

h. Gosta de sair com amigos, ir à festa, passeios em geral? Por quê? Com que frequência faz isso?

5- Planos frente ao futuro:

a. Você tem planos para seu futuro? Quais são?

b. Como gostaria de estar dentro de um intervalo de cinco a dez anos?

c. Está em seus planos ter filhos? Por quê?

d. Está em seus planos constituir uma família? Por quê?

Quarta Parte: Motivações da Escolha por permanecer solteiro

a. Qual a importância que considera ter um relacionamento estável?

b. Como foram os seus últimos relacionamentos?

c. Quais as vantagens e desvantagens de um relacionamento estável?

d. Você se sente bem na situação de permanecer solteiro?

e. Porque acha que fez esta opção?

f. Acha que pretende mudar de opção futuramente? Por quê?

g. Pretende se casar um dia? Por quê?

h. Pretende ter filhos? Por quê?

i. Sente algum preconceito por ter feito esta opção? Por parte de quem?

j. Possui amigos na mesma situação?

k. Acha esta uma situação confortável? Por mais quanto tempo?

1. Sente que seus pais o apoiam nisso?

m. Acha que esta opção pode ter relação com sentimentos ruins oriundos de relacionamentos anteriores? 